NBS MONOGRAPH 35

Bibliography and Index on Vacuum and

Low Pressure Measurement

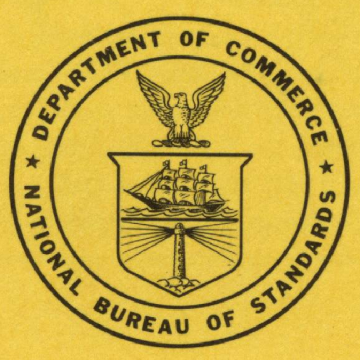

U.S. DEPARTMENT OF COMMERCE

NATIONAL BUREAU OF STANDARDS 


\section{THE NATIONAL BUREAU OF STANDARDS}

\section{Funetions and Aetivities}

The functions of the National Bureau of Standards are set forth in the Act of Congress, March 3, 1901, as amended by Congress in Public Law 619, 1950. These include the development and maintenance of the national standards of measurement and the provision of means and methods for making measurements consistent with these standards; the determination of physical constants and properties of materials; the development of methods and instruments for testing materials, devices, and structures; advisory services to government agencies on scientific and technical problems; invention and development of devices to serve special needs of the Government; and the development of standard practices, codes and specifications. The work includes basic and applied research, development, engineering, instrumentation, testing, evaluation, calibration services, and various consultation and information services. Research projects are also performed for other government agencies when the work relates to and supplements the basic program of the Bureau or when the Bureau's unique competence is required. The scope of activities is suggested by the listing of divisions and sections on the inside of the back cover.

\section{Publications}

The results of the Bureau's research are published either in the Bureau's own series of publications or in the journals of professional and scientific societies. The Bureau itself publishes three periodicals available from the Government Printing Office: The Journal of Research, published in four separate sections, presents complete scientific and technical papers; the Technical News Bulletin presents summary and preliminary reports on work in progress; and Basic Radio Propagation Predictions provides data for determining the best frequencies to use for radio communications throughout the world. There are also five series of nonperiodical publications: Monographs, Applied Mathematics Series, Handbooks, Miscellaneous Publications, and Technical Notes.

A complete listing of the Bureau's publications can be found in NBS Circular 460, Publications of the National Bureau of Standards, 1901 to June 1947 (\$1.25), the Supplement to NBS Circular 460, July 1947 to June 1957 ( $\$ 1.50$ ), and Miscellaneous Publication 240, July 1957 to June 1960 (includes titles of papers published in outside journals 1950 to 1959) (\$2.25); available from the Superintendent of Documents, Government Printing Office, Washington, D.C. 


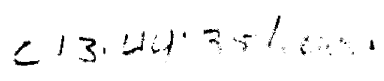

Errata to Accompany Nationat-Bureau of Standards Monograph 35 , Bribliogriphy and Index on Vacuum and Lov Pressure Measurements By W. G. Brombacher

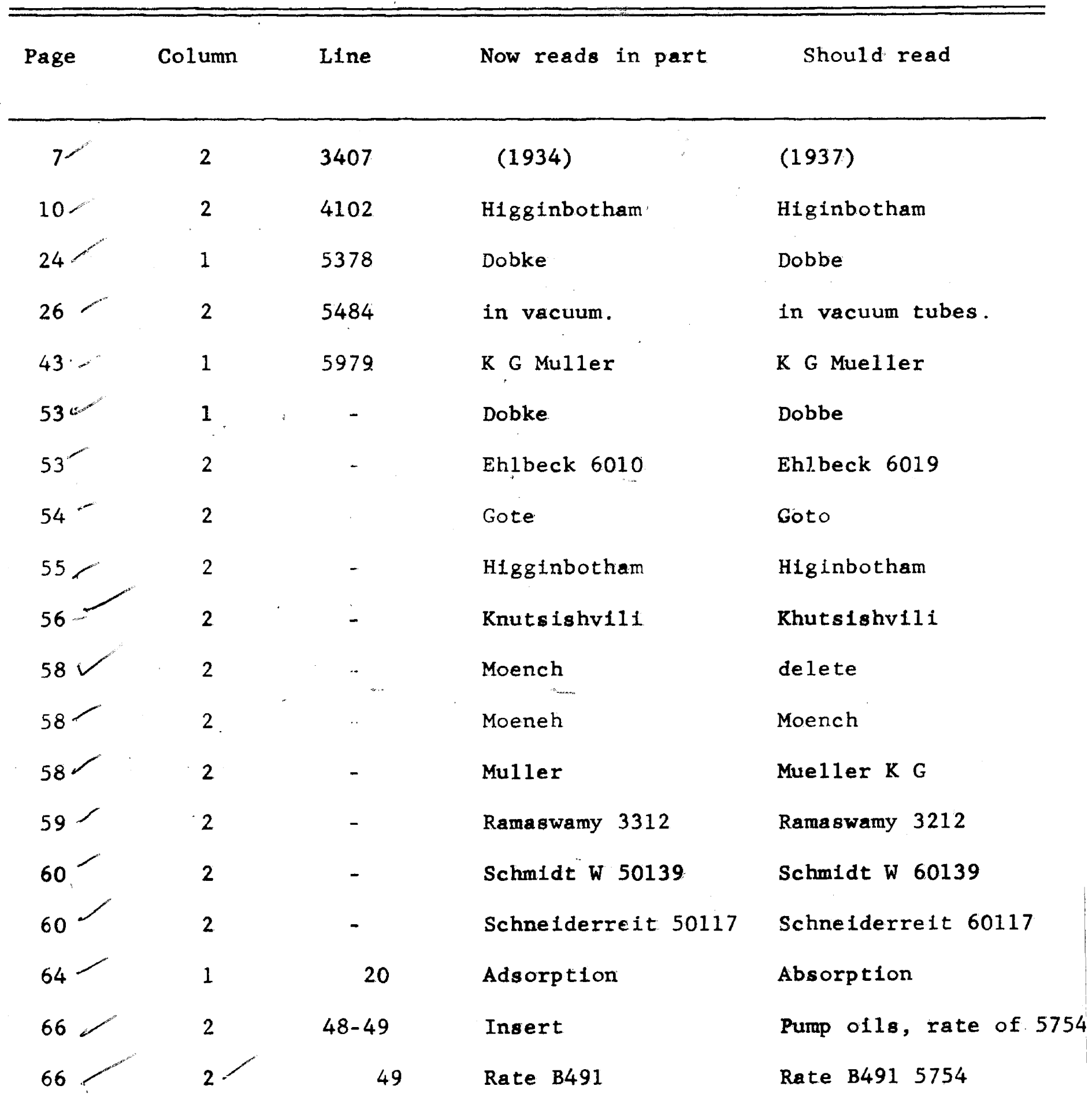




\begin{tabular}{|c|c|c|c|c|}
\hline Page & Column & Line & Now reads in part & Should read \\
\hline 67 & 1 & $30-31$ & Insert & Rate 5754 \\
\hline 75 & 1 & 15 & $5635 \quad 5823$ & $\begin{array}{lll}5635 & 5754 & 5823\end{array}$ \\
\hline 85 & 1 & 8 & Des1gn 5448 & Design $5121 \quad 5448$ \\
\hline-85 & 2 & 28 & Flat closure 2801 & F1at closure 4615 \\
\hline 85 & 2 & 46 & (Vacus tope) & (Vacustat) \\
\hline 85 & 2 & 49 & 011 type 5819 & 011 type 43015819 \\
\hline .85 & 2 & 64 & Cap1llary preseure & $\begin{array}{l}\text { cap1llary measures } \\
\text { pressure }\end{array}$ \\
\hline 86 & 1 & 11 & Boyles low & Boyles law \\
\hline 86 & 1 & 13 & $\begin{array}{l}\text { Condensable gases } \\
\text { B391 }\end{array}$ & Condensable gases B491 \\
\hline 95 & 1 & 20 & Tritium 5818 & Tritium 58118 \\
\hline
\end{tabular}

6.2

April 28, 1964 
UNITED STATES DEPARTMENT OF COMMERCE - Luther H. Hodges, Secretary NATIONAL BUREAU OF STANDARDS • A. V. Astin, Director

\title{
Bibliography and Index on Vacuum and Low Pressure Measurement
}

\author{
W. G. Brombacher
}

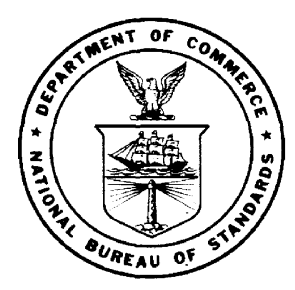

National Bureau of Standards Monograph 35

Issued November 10, 1961

For sale by the Superintendent of Documents, U.S. Government Printing Office Washington 25, D.C. - Price 60 cents 



\section{Foreword}

Preparation of this bibliography and index on vacuum and low pressure was undertaken to fill the need of scientists, engineers, and other users for sources of information. It was originally planned to include a critical review of vacuum and low pressure measurement with the bibliography. In order to avoid undue delay in the publication of the bibliography it was found advisable to omit the review which, however, will be prepared for separate publication.

This bibliography was prepared as part of the work on vacuum standards which is now in progress in the Mechanics Division under the supervision of D. P. Johnson, Chief of the Pressure and Vacuum Section.

A. V. Astin, Director, 


\section{Contents}

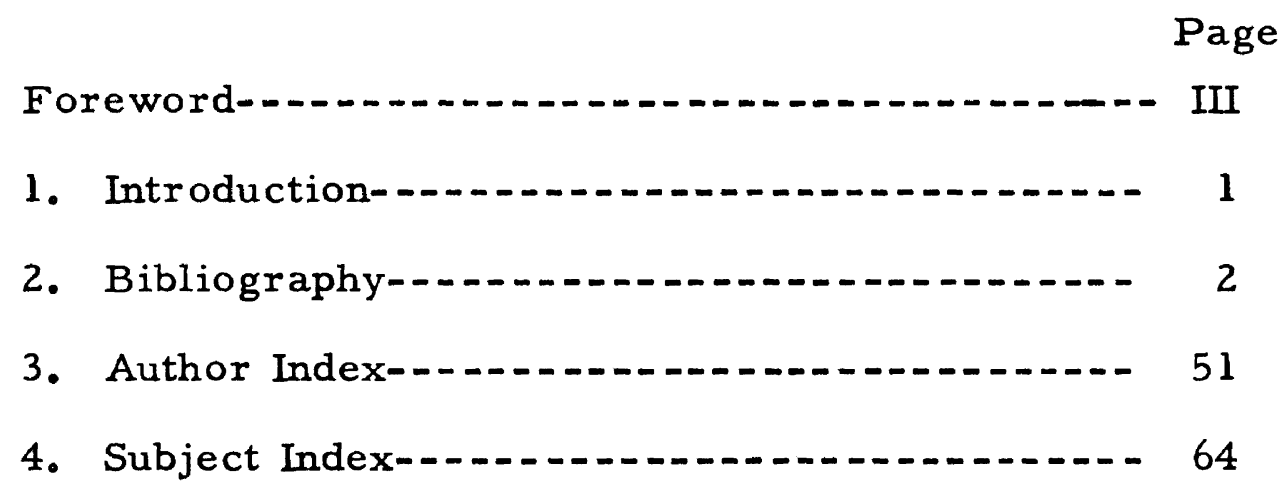




\section{W. G. Brombacher}

The bibliography contains 1538 references, of which 52 are on books. About 550 of the periodical references are specifically on pressure measurement including both vacuum gages and micromanometers. The balance are on vacuum technology, including adsorption, degassing, vacuum pumps, controlled gas leaks, valves, seals and vacuum systems, all of which bear on the technique of vacuum measurement. The indices consist of an author index and an index of the subject matter of the 1isted references.

\section{INTRODUCTION}

Vacuum technology has been advancing at a rapid$1 \mathrm{y}$ accelerating rate during the past few years in response to the needs of science and industry. To meet the need for means of locating technical information, abstracts of current literature on vacuum technology are available in a number of the publications. Notable among those specifically on vacuum technology are: a) Vacuum (since 1951), The international journal and abstracting service for vacuum science and technology. Pergamon Press, London. b) Le Vide (since 1946), Sociéte Française des Ingénieurs des Techniciens du Vide, Paris, France. 0ther abstract journals or publications containing a significant number of abstracts on vac uum measurement include c) Physical abstracts, Sea tion A of Science abstracts, Institution of Electrical Engineers, London. d) Chemical abstracts, American Chemical Society, Columbus, Ohio. e) Engineering index, Engineering Societies, New York. .f) Physikalische Berichte, Deutsche Gesellschaft für technische Physik, Braunschweig.

Excellent surveys of vacuum measurement are given in Dushman's "Scientific foundations of vao uum technique" (1949) and in Leck's "Pressure measurement in vacuum systems" (1957) but the references are incomplete and do not include the flood of papers published since. The preparation of an up-to-date bibliography, undertaken here, appears to fill a need for a source of readily available information. This paper consists essentially of a) a bibliography, b) an author index, and c) an index of the subject matter of the bibliography. While the primary objective is to focus on vacuum measurement, it was believed essential to include in the bibliography articles on vacuum technology in some measure accessory or essential to vacuum measurement. For maximum usefulness, an index of the subject matter of the references has been prepared. The abstract publications listed in the previous paragraph have been freely drawn upon in preparing the bibliography.

Neither surveys nor bibliographies appear to be available on micromanometers, covering absolute pressure measurements just above the high vacuum range or on sensitive, small differential pressure measurement. This instrumentation is of interest principally to workers in scientific and industrial laboratories. References to micromanometers are listed in the bibliography and are indexed similar$1 y$ as described in the preceding paragraph.

It was originally planned to include a critical review of vacuum and low pressure instrumentation with emphasis on possible standard instruments and on calibration methods. Preparing and including this review would delay publication unduly. Since the bibliography and indices will adequately meet the needs of many of those interested in the field, it was decided to issue the bibliography as prompt$1 \mathrm{y}$ as possible. The review will be prepared and issued separately.

Standard vacuum terminology has been proposed by the American Vacuum Society [58148] and the British Standards Institution [58104]. In the subject index the American proposed classification of degrees of high vacuum has been adhered to. This is

$\begin{array}{lr}\quad \text { Condition } & \text { Pressure range, Torr } \\ \text { High vacuum } & 10^{-3} \text { to } 10^{-6} \\ \text { Very high vacuum } & 10^{-6} \text { to } 10^{-9} \\ \text { U1tra-high vacuum } & 10^{-9} \text { and below }\end{array}$

The Torr equals $1 / 760$ of an atmosphere of pressure (1013.250 millibars) or at pressures in the vacuum range, one millimeter of mercury for all practical purposes.

The term micromanometers is rather generally used to designate designs of liquid or mechanical type pressure measuring instruments which are an order more sensitive than designs considered more or less standard. More specifically, micromanometers may be defined as instruments of the liquid or mechanical type used to measure absolute or differential pressure in the range from about $10^{-4}$ to $10 \mathrm{~mm}$ of mercury, with the ability to detect pressure changes of less than about $0.01 \mathrm{~mm}$ of mercury. It also includes water or oil manometers used to measure differential pressure, with a pressure change of less than about 0.01 inch of water detectable. 


\section{BIBLIOGRAPHY}

The references are divided into a list of books and a list of papers and reports, all listed chronologically, by years. Books are designated by the letter "B" followed by two digits indicating the year of publication and by a single digit identifying the order of 1isting. For example B592 indicates a book published in 1959, listed second in the book list. Papers and reports are designated by four digits or five, where necessary, the first two indicating the year of publication or issue, and the last two or three the order of listing. Thus 58122 indicates $122 \mathrm{~d}$ in the list for 1958.

The bibliography contains 1538 references, of which 52 are books. About 550 of the periodical references are specifically on pressure measurement. The period covered is up to January 1, 1961.

A reasonable effort was made to 1 ist all significant references on vacuum and low pressure instrumentation, particularly those published since 1949. Extensive, but not necessarily complete, references to vacuum technology and phenomena were included, since making valid vacuum measurements involve the effect of such phenomena as adsorption, degassing etc. References are therefore included on adsorption, degassing, outgassing, surface reaction, mechanical and diffusion pumps, leak detection, controlled gas leaks, and on hardware such as seals, valves, gaskets and vacuum systems. References on methods of calibrating vacuum gages and on standards of measurement are also listed.

Papers on micromanometers, both liquid and mechanical types, are listed. The criterion for inclusion of those measuring absolute or differential pressure is stated in the Introduction.

With minor exceptions neither catalogs, nor announcements in trade journals of new instruments without technical data, nor patents, are listed. Papers covering app.ications of vacuum technology are of necessity omitted, unless of some significance in vacuum measurement.
B241 J. R. Pane11, Fluid velocity and pressure. Edward Arnold \& Co., London, 135 p. (1924).

B261 L. Dunoyer, Vacuum practice. Translation by J. H. Smith, D. Van Nostrand Co., New York, 228 p. (1926).

B321 J. W. McBain, The sorption of gases and vapors by solids. E. Routledge \& Sons, London, 577 p. (1932).

B341 S. J. Gregg, The absorption of gases by solids. Methuen's Monographs on Chemical Subjects, Van Nostrand Co., New York, 120 p. (1934).

B381 E. H. Kennard, Kinetic theory of gases. McGraw-Hill Book Co., New York, 483 p. (1938).

B382 J. Strong, Procedures in experimental physics. (Technique of high vacuum, p. 93150) Prentice-Ha11, 642 p. (1938).

B391. A. Farkas \& H. W. Melville, Methods in gas reactions. Macmillan \& Co., 384 p. (1939).

B431 S. Brunauer, The absorption of gases and vapors. VI, Physical absorption. Princeton Univ. Press, 520 p. (1943).

B471 S. Jnanananda, High vacua. Van Nostrand, New York, 310 p. (1947).
B472 R. M. Barrer, Diffusion in and through solids. Cambridge Univ. Press, London, 464 p. (1947).

B473 L. H. Martin \& R. D. Hill, A manual of vacuum practice. Melbourne Univ. Press, 120 p. (1947).

B491 S. Dushman, Scientific foundations of vacuum technique. John Wiley \& Sons, New York, 882 p. (1949).

B492 A. Guthrie \& K. R. Wakerling, Vacuum equipment and techniques. McGraw-Hill Book Co., New York, 264 p. (1949).

B493 M. Benedick \& C. Williams, Engineering developments in the gaseous diffusion process. McGraw-Hil1 Book Co., New York, 129 p. (1949) .

B494 R. S. Burden, Surface tension and the spreading of liquids. Cambridge Univ. Press, 2d ed., 92 p. (1949).

B495 A. R. Miller, Absorption of gases on solids. Cambridge Univ. Press, 128 p. (1949).

B496 E. Ower, The measurement of air flow. (Chapter on manometers). Chapman \& Ha11, London, 293 p. (1949).

B501 M. Knudsen, Kinetic theory of gases: some modern aspects. John Wiley \& Sons, New York, 3d ed., 64 p. (1950). 
B502 R. Jaecke1, Vacuum, its measurement and production. In German. Springer-Verlag, Berlin, 301 p. (1950).

B503 G. Moench, High vacuum techniques. In German. R. A. Lang Verlag, Poessneck, 2d ed. of Vakuumtechnik im Laboratorium, $472 \mathrm{p}$. (1950).

B504 E. L. Holland-Merten, Handbook of vacuum technique. In German. W. Knapp, HalleSaale, 2d ed., 636 p. (1950).

B505 C. E. Normand et a1, Vacuum problems and techniques. Tennessee Eastman Corp., 265 p. (1950).

B506 L. Dunoyer, Vacuum and its app1ications. In French. Presses Universitaires de France, Paris, 112 p. (1950).

B511 L. Marton, Editor, Advances in Electronics, $v 3$, Chapter on field emission microscopy by F. Ashworth, p. 1-42. Academic Press, New York 357 p. (1951).

B512 M. Leblanc, Vacuum techniques. In French. Colin, Paris, 187 p. (1951).

B513 J. R. Davy, Industrial high vacuum. Pittman, London, 243 p. (1951).

B514 S. H. Gregg, Surface chemistry of solids. Reinhold Pub1. Corp., 297 p. (1951).

B515 H. Ebert, Compression vacuum gages. In German. Vieweg \& Sohn, Brunswick, $37 \mathrm{p}$. (1951).

B521 A. L. Reimann, Vacuum technique. Chapman \& Ha11, London, 449 p. (1952).

B522 W. Jost, Diffusion in solids, liquids and gases. Academic Press, New York, 558 p. (1952).

B523 A. C. Graves \& D. K. Frohman, Misce1laneous physical and chemical techniques of the Los Alamos project. McGraw-Hill Book Co., New York, 323 p. (1952).

B524 H. S. W. Massey \& E. H. S. Burhop, Electronic and ionic impact phenomena. Clarendon Press, 0xford, 669 p. (1952).

B531 G. P. Barnard, Modern mass spectrometry. 400 references. The Institute of Physics, London, 326 p. (1953).

B532 H. E. Newe11, Jr., High altitude rocket research. Academic Press, New York, 298 p. (1953).

B533 J. Reilly \& W. N. Rae, Physico-chemical methods. Vo1. 1, (Chapter on Pressure measurement, p. 233-258) D. Van Nostrand, 5 th ed., 760 p. (1953).

B541 T. E. Jordan, Vapor pressure of organic compounds, Interscience, New York, $266 \mathrm{p}$. (1954).
T. S. Gray, Applied electronics. John Wiley \& Sons, New York, 2d ed., 881 p. (1954).

B543 G. W. Morey, The properties of glass. Reinhold Pub1. Corp., 2d ed., 591 p. (1954).

B551 J. Yarwood, High-vacuum technique. John Wiley \& Sons, New York, 3d ed., 208 p. (1955).

B561 G. N. Patterson, Molecular flow of gases. John Wiley \& Sons, 217 p. (1956).

B571 J. H. Leck, Pressure measurement in vacuum systems. 192 references. Institute of Physics, London, 144 p. (1957).

B572 M. Auwaerter, Editor, Vacuum techniques and the physics of evaporated films. In German. Wissenschaft1iche Verlagsgese11schaft, Stuttgart, 282 p. (1957).

B581 K. Diels \& R. Jaecke1, Vacuum handbook for laboratory and industry. In German. 52 pages of references. Springer-Verlag, Ber1in, 270 p. (1958).

B582 H. E. Duckworth, Mass Spectroscopy. Cambridge Univ. Press, 206 p. (1958).

B583 D. H. Everett \& F. S. Stone, Editors, The structure and properties of porous materials. Tenth Symposium, Colston Research Soc., Academic Press, 389 p. (1958).

B591

M. Kno11, Materials and processes of electron devices. 2300 references. Springer Verlag, Berlin, 484 p. (1959).

B592 K. S. Lion, Instrumentation in scientific research; electrical input transducers. McGraw-Hill Book Co., New York, 324 p. (1959).

B593

W. Espe, Materials for high vacuum applications. Vo1. 1, Metals and metallic conductors. In German. Deutscher Verlag der Wissenschaften. 916 p. (1959).

B594

J. D. Waldron, Editor, Advances in mass spectrometry. 2000 references. Pergamon Press, Oxford, 704 p. (1959).

B601 A. B. Adamson, Physical chemistry of surfaces. Interscience Publishers, $629 \mathrm{p}$. (1960).

$\mathrm{B} 602$ S. Schwartz, Editor, Selected semiconductor circuits handbook. John Wiley \& Sons, 503 p. (1960).

B603 N. R. Nilsson, Editor, Ionization phenomena in gases. Fourth Intern. Conf. on Ionization Phenomena in gases, Upsala, 1959. North-Ho1land Pub1. Co., 2 vo1. 1210 p. (1960). 
7401 H. McLeod, Apparatus for measurement of 1ow pressures of a gas. Phil. Mag. 48, 110-112 (1874).

0501 K. Prytz, Sensitive detector of the position of a reflecting surface. In German. Ann. Phys. (4) 16, 735-745 (1905).

0601 M. Pirani, Continuous1y indicating vacuum gage. In German. Deut. Phys. Ges. Verh. $\underline{8}$, 686-694 (1906).

0602 W. Voege, A new vacuum gage. In German. Phys. Zt. 7, 498-500 (1906).

0901 F. M. G. Johnson \& D. McIntosh, Liquid ch1orine. Am. Chem. Soc., 31, 1138-1144 (1909).

0902 K. Schee1 \& W. Heuse, On an apparatus for measuring very low pressures. In German. Zt. Instrumentenk. 29, 14-20 (1909).

$0903 \mathrm{~K}$. Schee1 \& W. Heuse, Two mercury manometers for measuring low pressure. In German. $\mathrm{Zt}$. Instrumentenk. 29, 344-349 (1909).

1001 M. Knudsen, Thermal molecular pressure of gases in tubes and porous bodies. In German. Ann. Phys. 31, 633-640 (1910).

1002 M. Knudsen, An absolute manometer. In German. Ann. Phys. 32, 809-842 (1910).

1101 M. Knudsen, The molecular heat conductivity of gases and the accommodation coefficient. In German. Ann. Phys. 34, 593-656 (1911).

1102 M. Von Smoluchowski, On the theory of the heat conductivity of gases at low pressure and the resulting pressure. In German. Ann. Pinys. 35, 983-1004 (1911).

1103 C. F. Hale, On the measurement of very small gas pressures. Trans. Am. Electro. Chem. Soc. 20, 243-258 (1911).

1301 I. Langmuir, Chemical reactions at very low pressures. I. The clean up of oxygen in a tungsten Iamp. J. Am. Chem. Soc. 35, 105127 (1913).

1302 I. Langmuir, Chemical reactions at very 1ow pressures. II. Chemical clean up of nitrogen in a tungsten lamp. J. Am. Chem. Soc. $\underline{35}, 931-945$ (1913).

1303 E. Von Angerer, The pressure of cathode rays. In German. Ann. Phys. 41, 1-29 (1913).

1304 I. Langmuir, The effect of space charges and residual gases on thermionic currents in high vacuum. Phys. Rev. 2, 450-486 (1913).

1305 W. Gaede, External friction of gases. In German. Ann. Phys. 41, 289-336 (1913).
1306 C. F. Muende1, Measurement and theory of 1ow pressures at low temperatures. In German. Zt. phys. Chem., 85, 435-465 (1913).

1401 I. Langmuir \& G. M. J. Mackay, The dissociation of hydrogen into atoms. I. Experimenta1. J. Am. Chem. Soc. 3ó, 1708-1722 (1914).

1402 J. W. Woodrow, Experiments on the production and measurement of high vacua. Phys. Rev. 4, 491-497 (1914).

1403 M. Knudsen, Determination of the molecular weights of a small quantity of gas. In German. Ann. Phys. 44, 525-536 (1914).

1404 F. Haber \& F. Kerschbaum, Measurement of 1ow pressures with an vibrating quartz fiber. In German. Zt. Elektrochem. 20, 296-305 (1914).

1405 W. Rohn, A continuous $1 y$ indicating electric vacuum gage. In German. $\mathrm{Zt}$. Elektrochem. 20, 539-542 (1914).

1406 J. B. Firth, The sorption of hydrogen by charcoal at liquid air temperatures. In German. Zt. phys. Chem. 86, 294-308 (1914).

1501 I. Langmuir, The dissociation of hydrogen into atoms. II. Calculation of the degree of dissociation and heat of formation. J. Am. Chem. Soc. 37, 417-458 (1915).

1502 I. Langmuir, Chemical reactions at 1ow pressures. J. Am. Chem. Soc. 37, 1139-1167 (1915).

1601 0. E. Buckley, An ionization manometer. Proc. Nat. Accd. Sci. 2, 683-685 (1916).

1701 S. Weber, Experimental research on the heat conductivity of gases. In German. Ann. Phys. 54, 325-356, 437-462 (1917).

1801 J. E. Shrader \& R. G. Sherwood, Production and measurement of high vacua. Phys. Rev. 12, 70-80 (1918).

1802 I. Langmuir, The absorption of gases on plane surfaces of glass, mica and platinum. J. Am. Chem. Soc. 40, 1341-1403 (1918).

1901 J. E. Shrader \& H. M. Ryder, An optical lever manometer. Phys. Rev. 13, 321-326 (1919).

1902 Masamichi So, On an ionization manometer. Proc. Phys. Math. Soc. (Japan) 1, 76-87 (1919).

1903 G. D. West, On the forces acting on heated metal foil surfaces in rarified gases. Proc. Phys. Soc. London, 32, 166-189, 222-231 (1919-20). 
1904 L. F. Richardson, A form of Knudsen's vacuum manometer. Proc. Phys. Soc., London, 31, 270-277 (1919).

1905 G. W. Todd, A simple theory of the Knudsen vacuum gauge. Phi1. Mag. 38, 381-382 (1919).

1906 J. E. Shrader, Residual gases and vapors in highly exhausted glass bulbs. Phys. Rev. 13, 434-437 (1919).

1907 I. Langmuir, Chemical reactions at low pressures. IV. The cleanup of nitrogen by a heated molybdenum filament. J. Am. Chem. Soc. 41, 167-194 (1919).

2101 S. Dushman \& C. G. Found, Studies with the ionization gauge. I. Construction and method of calibration. Phys. Rev, 17, 7-19 $(1921)$.

2102 N. R. Campbe11, A method for the micro-analysis of gases by the use of the Pirani pressure gauge. Proc. Phys. Soc., London, 33, 287-296 (1921).

2103 A. H. Pfund, An extension of the range of the Mcleod gauge. Phys. Rev. 18, 78-82 (1921).

2301 E. K. Carver, An improved optical lever manometer. J. Am. Chem. Soc. 45, 59-63 (1923).

2302 A. S. Coolidge, The upper range of the quartzfiber manometer. J. Am. Chem. Soc. 45, 16371643 (1923).

2303 J. E. Harris \& E. E. Schumacher, Measurements on the gases evolved from glasses of known chemical composition. J. Ind. Eng. Chem. 15, 174-177 (1923).

2401 G. Hettner, On the theory of radiometers. In German. Zt. Phys. 27, 12-22 (1924).

2402 C. G. Found \& S. Dushman, Studies with ionization gauge. Phys. Rev. 23, 734-743 (1924).

2403 H. Simon, Ionization gages. In German. Zt. tech. Phys. 5, 221-233 (1924).

2404 D. H. Bangham \& F. P. Burt, The behavior of gases in contact with glass surfaces. Proc. Roy. Soc., London, A105, 481-488 (1924).

2405 J. J. Manley, A preliminary measurement of a primary gas-grown skin. Proc. Phys. Soc., London, 36, 288-290 (1924).

2406 N. R. Campbe11 \& E. G. New, The disappearance of gas in the electrical discharge. Phil. Mag. 48, 553-580 (1924).

2407 A. Einstein, 0n the theory of radiometic forces. In German. Zt. Phys. 27, 1-6 (1924).
2501 M. Abraham, Theory of ionizationgages. In German. Zt. tech. Phys. 6, 437-438 (1925).

2502 K. T. Compton \& C. C. Van Voorhis, Probability of ionization of gas molecules by electron impacts. Phys. Rev. 26, 436-453 (1925).

2503 M. L. Hamlin, A laboratory vacuum gage. J. Am. Chem. Soc. 47, 709-712 (1925).

2504 E. B. King, Two new types of high vacuum gauge. Proc. Phys. Soc., London 38, 80-84 (1925).

2505 W. A. Patrick \& J. S. Long, The adsorption of butane by silica ge1. J. Phys. Chem. 29, 336-343 (1925).

2506 M. Volmer, Thermodynamic consequences from the equation of state for adsorbed substances. In German. Zt. phys. Chem. 115, 253-260 (1925).

2507 W. A. Patrick, W. C. Preston \& A. E. Owens, A study of adsorption phenomena in the vicinity of the critical temperature. J. Phys. Chem. 29, 421-434 (1925).

2508 W. A. Patrick \& L. H. Opdycke, The adsorption of vapors by silica gel by a dynamic method. J. Phys. Chem. 29, 601-609 (1925).

2601 J. J. Hopfield, Capillary valves for gases. J. 0pt. Soc. Am. 12, 391-392 (1926).

2602 K. T. Compton \& C. C. Van Voorhis, Probabi1ity of ionization of gas molecules by electron impacts. II. Critique. Phys. Rev. 27, 724-731 (1926).

2603 E. Brueche, On plate and fiber vacuum gages. In German. Ann. Phys. 79, 695-733 (1926).

2604 C. G. Found \& N. B. Reynolds, Direct reading ionization gauge. J. Opt. Soc. Am. \& Rev.Sci. Inst. 13, 217-222 (1926).

2605 E. Rumpf, A thermoelectric vacuum gage. In German. Zt. tech. Phys. 7, 224-226 (1926).

$2606 \mathrm{H}$. Rowe, The adsorption of gases by activated charcoal at very low pressures. I. At air temperature. II. At $-183^{\circ} \mathrm{C}$. Phil. Mag. 1, $109-131$, 1042-1054 (1926).

$2701 \mathrm{~J}$. J. Manley, On the construction and standardization of an interferometer pressure gauge. Proc. Phys. Soc., London, 40, 57-61 (1927-28).

2702 H. H. Lowry \& P. S. 01mstead, The adsorption of gases by solids with special reference to the adsorption of carbon dioxide by charcoal. J. Phys. Chem. 31, 1601-1626 (1927).

2703 G. Glockler, W. P. Baxter \& R. H. Dalton, The activation of molecular hydrogen by electron impact. J. Am. Chem. Soc. 49, 58-65 (1927). 
2704 A. L. Hughes \& A. M. Ske1let, Dissociation of hydrogen by electrons. Phys. Rev. 30, 11-25 (1927).

2801 R. J. Clark, A method of calibration of a McLeod gauge. J. Sci. Inst. 5, 126-130 (1928).

2802 I. Langmuir \& H. A. Jones, Collisions between electrons and gas molecules. Phys. Rev. 31, 357-404 (1928).

2803 G. Mierde1, Electrodeless ring current. In German. Ann. Phys. 85, 612-640 (1928).

2804 E. Brueche \& W. Littwin, Experimental research on radiometer problems. In German. Zt. Phys. 52, 318-333 (1928).

2805 L. F. Stanley, The construction and calibration of a sensitive form of Pirani gauge for measurement of high vacua. Proc. Phys. Soc. London, 41, 194-203 (1928-29).

2806 H. Zeise, Research on the monomolecular character of the adsorption of gases on glass and charcoa1. In German. Zt. phys. Chem. A136, 385-418 (1928).

2901 M. C. Johnson \& G. 0. Harrison, A pressure gauge for continuous reading in moderate vacua. J. Sci. Inst. 6, 305-308 (1929).

2902 A. R. 01sen \& L. L. Hirst, A new differential pressure gage. J. Am. Chem. Soc. 51, 23782379 (1929).

2903 K. C. D. Hickman, On some vacuum gauges. J. Opt. Soc. Am. 18, 305-331 (1929).

2904 G. Kornfeld \& E. K1ingler, The kinetics of the reaction $2 \mathrm{NO}+\mathrm{O}_{2}=2 \mathrm{NO}_{2}$ at low pressures. In German. Zt. phys. Chem. B, 4, 37-66 (1929).

2905 A. Simon \& F. Fehér, New method for the distant indication of sma11 pressures. In German. Zt. Elektrochem. 35, 162-165 (1929).

2906 E. Mueller \& K. Schwabe, The absorption of hydrogen by platinum metals. In German. $2 t$. Elektrochem. 35, 165-184 (1929).

2907 A. Magnus \& H. Kratz, On the adsorption of carbon dioxide and ammonia by charcoal and graphite. In German. Zt. anorg. Chem. 184, 241-271 (1929).

2908 A. Magnus, Theory of gas adsorption. In German. Zt. phys. Chem. A142, 401-430 (1929).

2909 C. R. Burch, Some experiments on vacuum distillation. Proc. Roy. Soc., London, Ser. A 123, 271-284 (1929).
$2910 \mathrm{~J}$. L. Hodgson, A sensitive micromanometer. J. Sci. Inst. $\underline{6}, 153-156$ (1929).

3001 J. K. Roberts, The exchange of energy between gas atoms and solid surfaces. Proc. Roy. Soc. A129, 146-161 (1930).

3002 M. Knudsen, Radiometric pressure and accommodation coefficients. In German. Ann. Phys. 6, 129-185 (1930). Translation into English̆: K. Danske Vidensk Selsk. 11, No. 1 (1930-32).

3003 P. T. Smith, The ionization of helium, neon, and argon by electron impact. Phys. Rev. 36, 1293-1302 (1930).

3004 W. Bleakney, The ionization of hydrogen by single electron contact. Phys. Rev. 35, 1180-1186 (1930).

3005 W. Bleakney, Ionization potentials and probabilities for the formation of multiply charged ions in helium, neon and argon. Phys. Rev. 36, 1303-1308 (1930).

3006 P. Bricout, Absolute manometer, electrostatica11y compensated. Compte Rendus 190, 733735 (1930).

3007 E. A. Stewardson, A continuous reading aneroid manometer for moderate1y low pressures. J. Sci. Inst. 7, 217-221 (1930).

3101 A. E1lett \& R. M. Zabe1, The Pirani gauge for the measurement of sma11 changes in pressure. Phys. Rev. 37, 1102-1111 (1931).

3102 N. B. Reynolds, Studies with an ionization gauge. Physics 1 , 182-191 (1931).

3103 M. D. Sarbey, Measurement of vacuum in radio tubes. Electronics 2, 594-595 (1931).

3104 P. T. Smith, The ionization of mercury vapor by electron impact. Phys. Rev. 37, 808-814 (1931).

3105 E. K. Jaycox \& H. W. Weinhart, A new design of an ionization manometer. Rev. Sci. Inst. $\underline{2}, 401-411$ (1931).

3106 T. G. Pearson, A manometer for measuring low pressures of easily condensable gases. Zt. phys. Chem. A, 156, 86-88 (1931).

3107 K. Sommermeyer, Sensitive diaphragm manometer. In German. Zt. phys. Chem. A, 155, 208-210 (1931).

3108 T. Theodorsen, Investigation of the diaphragm type pressure ce11. Nat. Advisory Comm. Aeronaut. Tech. Report No. 388, 18 p. (1931). 
3109 S. Dushman, Recent advances in the production and measurement of high vacua. 59 references. J. Frank1in Inst. 211, 689-750 (1931).

3110 P. I. Lukirsky \& S. W. Ptizyn, On the absorption of metastable and ionized nitrogen by magnesium. In German. $\mathrm{Zt}$. Phys. 71, 339-349 (1931).

3111 A. Betz, A micromanometer with convenient indicating means. In German. Messtechnik 7, 37-39 (1931).

3201 K. Newbury \& C. L. Utterback, Low vapor pressure gauge. Rev. Sci. Inst. 3, 593-595 (1932) .

3202 J. K. Roberts, The exchange of energy between gas a toms and solid surfaces. II. The temperature variation of the accommodation coefficient of helium. Proc. Roy. Soc. A135, 192-205 (1932).

3203 J. T. Tate \& P. T. Smith, The efficiencies of ionization and ionization potentials of various gases under electron impact. Phys. Rev. 39, 270-277 (1932).

3204 E. Fredlund, on the performance limits of the Knudsen manometer. In German. Ann. Phys. 13, 802-810 (1932).

3205 E. Fredlund, Investigation of the Knudsen manometer. In German. Ann. Phys. 14, 617643 (1932).

3206 L. A. DuBridge \& W. W. Roehr, The thermionic and photoelectric work functions of molybdenum. Phys. Rev. 42, 52-57 (1932).

3207 H. K1umb \& T. Haase, Measurement of differences in mercury level. In German. Zt. tech. Phys. 13, 372-373 (1932).

3208 M. R. Andrews, Reaction of gases with incandescent tantalum. J. Am. Chem. Soc. 54, 1845-1854 (1932).

3209 G. Glockler \& J. L. Wilson, The activation of molecular oxygen by electron impact. J. Am. Chem. Soc. 54, 4544-4556 (1932).

3210 K. Neumann \& E. Voelker, Torsion balance method of measuring sma11 vapor pressure. Zt. phys. Chem. A161, 33-45 (1932).

3211 M. Rusch \& 0. Bunge, Sources of error in measuring pressure using a cold trap. In German. Zt. tech. Phys. 13, 77-81 (1932).

3212 K. H. Ramaswamy, The calibration of a McLeod gauge in a vacuum system. Phil. Mag. 14, 96-99 (1932).
3301 A. W. Porter, Capillary ascent or depression of liquids in cylindrical tubes. Trans. Faraday Soc. 29, 702-707 (1933).

3302 J. K. Roberts, The exchange of energy between gas atoms and solid surfaces. III. The accommodation coefficient of neon. Proc. Roy. Soc. A142, 518-524 (1933).

3303 R. J. Cashman \& W. S. Huxford, Photoelectric sensitivity of magnesium. Phys. Rev. 43, 811-818 (1933).

3304 H. Murmann, Vacuum measurement by means of hot wires. In German. Zt. Phys.86, 14-20(1933).

3305 H. Murmann, Hot wire indicating vacuum gage. In German. Zt. tech. Phys. 14,538-540 (1933).

3306 A. L. Reimann, The cleanup of hydrogen by magnesium. Phil. Mag. 16, 673-686 (1933).

3307 I. Langmuir, Surface chemistry. 37 references. Chem. Reviews 13, 147-191 (1933).

3308 W. von Meyeren, Improvement of vacua by electrical discharge. In German. Zt. Phys. 84, 531-540 (1933).

3309 R. M. Zabe1, Vapor pressure of vacuum cements. Rev. Sci. Inst. $\underline{4}, 233-234$ (1933).

3401 B. G. Dickins, The effect of accommodation on heat conduction through gases. Proc. Roy. Soc. A143, 517-540 (1934).

3402 W. B. Mann, Exchange of energy between platinum surface and gas molecules. Proc. Roy. Soc. A146, 776-791 (1934).

3403 A. L. Reimann, The clean-up of various gases by magnesium, calcium and barium. Phil. Mag. 18, 1117-1132 (1934).

3404 N. Morgulis, On the theory of ionization gages. In German. Phys. Zt. Sowjetunion 5, 407-417 (1934).

3405 S. G. Foord, An improved Bourdon gauge. J. Sci. Inst. 11, 126-127 (1934).

3406 W. Gaede, Vacuum measurement. In German. Zt. tech. Phys. 15, 664-668 (1934).

3407 J. B. H. Kuper, A. C. operation of an ionization gauge. Rev. Sci. Inst. 8, 394 (19537

3408 W. P. Overbeck \& F. A. Meyer, Grid current control for the ionization gauge. Rev. Sci. Inst. 5, 287-289 (1934).

3409 R. M. Barrer, The mechanism of activated diffusion through silica glass. J. Chem. Soc. p. 378-386 (1934).

3410 W. von Meyeren, Improvement of vacua by electrical discharge. II. In German. Zt. Phys. 91, 727-736 (1934). 
3501 M. J. Copley, T. E. Phipps \& J. Glasser, An ionization gage for the detection of molecular rays. Rev. Sci. Inst. $\underline{6}, 371$ (1935).

3502 P. A. Anderson, The contact difference of potential between tungsten and barium. The external work function of barium. Phys. Rev. 47, 958-964 (1935).

3503 R. E. H. Rasmussen, Radiometer force and dimensions of radiometer elements. In German. Ann. Phys. 22, 643-656 (1935).

3504 J. W. M. DuMond \& W. N. Pickels, Superiority of a Knudsen type vacuum gauge for large metal systems with organic vapor pumps; its design and operation. Rev. Sci. Insts. 6, 362-370 (1935).

3505 M. Francis, On the use of the McLeod gauge with non-permanent gases. Trans. Faraday Soc. 31, 1325-1331 (1935).

3506 V. Kunz1 \& J. Slavik, Valve for close regulation of the pressures of gases and its application to vacuum tubes. In German. Zt. tech. Phys. 16, 272-276 (1935).

3507 H. Moser, Rotating vacuum gauge with three ranges covering 0.0001 to $700 \mathrm{~mm} \mathrm{Hg}$. In German. Phys. Zt. 36, 1-2 (1935).

3508 R. H. Fowler, A statistical derivation of Langmuir's adsorption isotherm. Proc. Camb. Phi1. Soc. 31, 260-264 (1935).

3509 W. G. Palmer \& R. E. D. Clark, Adsorption on measured surfaces of vitreous silica. I. \& II. Proc. Roy. Soc., London, A149, 360-384 (1935); A160 254-267 (1937).

3510 H. Reichardt, Torsion balance micromanometer. Zt. Instrumentenk. 55, 23-33 (1935).

3511 H. Reichardt, Pressure gage for sma11 pressure differences. In German. Ver. Deut. Ing. 79, 1503-1504 (1935).

3601 E. Schmidt, Measuremeit of sma11 pressure differences at high pressures. Ver. Deut. Ing. 80, 635 (1936)

3602 R. D. Huntoon \& A. E1lett, Ionization gauge for atomic beam measurements. Phys. Rev. 49, 381-387 (1936).

3603 W. Heinze \& S. Wagner, Activation of oxidecathodes. I. Changes in the emitting area. In German. Zt. tech. Phys. 17, 645-653 (1936).

3604 H. G. de Boer \& J. D. Fast, The influence of oxygen and nitrogen on the $\alpha-\beta$ transition of zirconium. Rec. trav. Chim. 55, 459-467 (1936).
3605 E. W. Muller, Theory of electron emission under the act on strong fields. Phys. Zt. 37, 838-842 (1936); 2t. tech. Phys. 17, $\overline{412}-416$ (1936)

3606 E. W. Mull1er, Dependence of the emission of field electrons on the work function. In German. Zt. Phys. 102, 734-761 (1936).

3607 C. J. Smithe11s \& C. E. Rans1ey, The diffusion of gases through metals. III. The degassing of nickel and the diffusion of carbon monoxide through nickel. Proc. Roy. Soc., London, 155, 195-212 (1936).

3608 C. F. DeVoe, The photoelectric properties of zinc. Phys. Rev. 50, 481-485 (1936).

3609 K. C. D. Hickman, Vacuum pumps and pump oils. Part II. Comparison of pump oils. J. Frank1in Inst. 221, 383-402 (1936) .

3610 K. C. D. Hickman, Vacuum pumps and pump oils. Part I. Fractionation pumps. J. Franklin Inst. 221, 215-235, 383-402 (1936).

3611 V. Deitz, The vapor pressure of potassium chloride and caesium iodide crystals. J. Chem. Physics, 4, 575-580 (1936).

3612 Th. Haase, G. Klages \& H. Klumb, Heat loss of bodies in gases and application to measurement of gas pressure. In German. Phys. Zt. 37, 440-444 (1936).

3613 H. Klumb \& Th. Haase, Low pressure manometers. In German. Phys. Zt. 37, 27-32 (1936).

3614 R. H. Fowler, Adsorption isotherms. Critical conditions. Proc. Camb. Phil. Soc. 32, $144-151$ (1936)

3615 H. A1terthum, A. Lompe \& R. Seeliger, Cleanup of inert gases by electric discharge. In German. Zt. tech. Phys. 17, 407-412 (1936).

3616 H. J. de Boer \& J. D. Fast, The $\alpha-\beta$ transition of zirconium in the presence of hydrogen. Rec. trav. Chim. 55, 350-356 (1936).

3701 K. C. D. Hickman, J. C. Hecker \& N. D. Embree, Determination of low vapour pressures. Ind. Eng. Chem., Ana1. Ed. 9, 264267 (1937).

3702 W. B. Mann \& W. C. Newe11, The exchange of energy between a platinum surface and hydrogen and deuterium molecules. Proc. Roy. Soc. A158, 397-402 (1937).

3703 G. C. Dunlap \& J. G. Trump, Thermocouple gauge for vacuum measurement. Rev. Sci. Inst. 8, 37-38 (1937).

3704 J. B. Hoag \& N. M. Smith, Jr., A thyratroncontrolled ionization gauge. Rev. Sci. Inst. 7, 497-499 (1937). 
3705 F. M. Penning, High vacuum gauges. Philips. Tech. Rev. 2, 201-208 (1937).

3706 F. M. Penning, A new manometer for low gas pressures. In German. Physica 4, 71-75 (1937).

3707 L. N. Ridenour \& C. H. Lampson, Thermionic control of an ionization gage. Rev. Sci. Inst. 8 , 162-164 (1937).

3708 E. A. Lederer \& D. H. Halmsley, Batalum, a barium getter for metal tubes. RCA Review 2, 117-123 (July 1937).

3709 A. L. Hughes, Simple Knudsen gauge. Rev. Sci. Insts. $8,409-412$ (1937).

3710 E. Fred1und, Low pressure radiometer manometer. In German. Ann. Phys. 30, 99-112 (1937).

3711 E. W. Mưller, Field emission and cathodic dispersion of thoriated tungsten. In German. Zt. Phys. 106, 132-140 (1937).

3712 E. H. Mứller, Electron microscope observation of field cathodes. In German. $\mathrm{Zt}$. Phys. 106, 541-550 (1937).

3713 L. Walden, Instrument suspensions, J. Sci. Inst. 14, 257-268 (1937).

3714 J. B. H. Kuper, A vacuum gauge for leak hunting. Rev. Sci. Inst. 8, 131-132 (1937).

3715 J. R. Lacher, A theoretical formula for the solubility of hydrogen in palladium. Proc. Roy. Soc., London, A161, 525-545 (1937).

3716 H. Adzumi, On the flow of gases through a porous wa11. Bul1. Chem. Soc., Japan 12, 304-312 (1937).

3717 K. B. Nottingham, Electrical and luminescent properties of willemite under electron bombardment. J. App1. Phys. 8, 762-778 (1937).

3801 P. Rosenberg, Method for diminishing the sticking of mercury in capillaries. Rev. Sci. Inst. 9, 258-259 (1938).

3802 E. W. Flosdorf, A simplified and portable McLeod gage. Ind. Eng. Chem., Ana1. Ed. 10, 534 (1938).

3803 C. T. Archer, Thermal conduction in hydrogen-deuterium mixtures. Proc. Roy. Soc. A165, 474-485 (1938).

3804 H. Spencer-Gregory \& E. H. Dock, The effect of temperature on the thermal conductivity and the accommodation coefficient of hydrogen below $0^{\circ} \mathrm{C}$. Phil. Mag. 25, 129-147 (1938).

3805 C. G. Montgomery \& D. D. Montgomery, Grid controlled ionization gage. Rev. Sci. Insts. 9, 58 (1938).
3806 F. Fredlund, Absolute measurement of radiometric action in gases. Phil. Mag. 26, 987-1000 (1938).

3807 A. E. Lockenvitz, Radiometer-type vacuum gage. Rev. Sci. Insts. 9, 417-420 (1938).

3808 P. A. Anderson, The contact difference of potential between barium and magnesium. Phys. Rev. 54, 753-757 (1938).

3809 E. W. Muller, Further observations with the field electron microscope. Zt. Phys. 108, 668-680 (1938).

3810 H. Hunsmann, A differential method of measuring small amounts of absorbed gases. In German. Zt. Elektrochem. 44, 540-542 (1938).

3811 S. Brunauer, P. H. Enmett \& E. Teller, adsorption of gases in multimolecular layers. J. Am. Chem. Soc. 60, 309-319 (1938).

3812 F. J. Wilkins, Statistical mechanics of the adsorption of gases at solid surfaces. Proc. Roy. Soc., London, A164, 496-509 (1938).

3813 F. J. Wilkins, The adsorption of argon, nitrogen and oxygen on smooth platinum foil at low temperatures and pressures. Proc. Roy. Soc., London, A164, 510-531 (1938).

3901 P. Rosenberg, Design of an accurate McLeod gauge. Rev. Sci. Insts. 10, 131-134 (1939).

3902 B. Raines, The accommodation coefficient of helium on nicke1. Phys. Rev. 56, 691-695 (1939).

3903 G. Wetterer, Quartz fiber manometer. In German. Zt. techn. Phys. 20, 281-283 (1939).

3904 R. Grigorovici, Simple glass manometer for 1ow pressures. 2t. tech. Phys. 20, 102104 (1939).

3905 E. J. Scott, An automatic Pirani vacuum gauge. Rev. Sci. Inst. 10, 349-350 (1939).

3906 F. H. Verhoek \& A. L. Marsha11, Vapor pressures and accommodation coefficients of four non-volatile compounds. J. Am. Chem. Soc. 61, 2737-2742 (1939).

3907 J. P. Blewett, The properties of oxide-cathodes. I. \& II. J. App1. Phys. 10, 668-679, 831-848 (1939).

3908 L. T. Work \& V. W. Haedrich, Performance of ejectors as a function of molecular weights of vapors. 27 references. J. Ind. Eng. Chem. 31, 464-477 (1939).

3909 S. T. Martin, on the thermionic and adsorptive properties of the surfaces of a tungsten single crystal. Phys. Rev. 56, 947959 (1939). 
3910 S. Werner, A simple Knudsen gage. Zt. tech. Phys. 20, 13-16 (1939).

4001 P. Sederholm \& C. Benedicks, Differential liquid manometer of high sensitivity, founded on 0. Pettersson's theory of submarine waves. Arkiv f. Mat. Astro, och Fys. 27A, 8, 5 p. (1940).

4002 L. F. Ehrke \& C. M. Slack, Gettering powers of various metals for $\mathrm{H}_{2}, \mathrm{O}_{2}, \mathrm{~N}_{2} \mathrm{CO}_{2}$ and air. J. App1. Physics 11, 129-136 (1940).

4003 R. S. Morse \& R. M. Bowie, Ionization gage. Rev. Sci. Insts. 11, 91-94 (1940).

4004 R. M. Bowie, Ionization gage circuit. Rev. Sci. Inst. 11, 265-267 (1940).

4005 E. Fredlund, Absolute measurements of radiometric action in gases. Ir. Ark. Mat. A stron. Fys. A27, No. 12 (1940).

4006 P. A. Anderson, Contact p. d. between Ba and $\mathrm{Zn}$. External work function of $\mathrm{Zn}$. Phys. Rev. 57, 122-127 (1940).

4007 M. Benjamin \& R. 0. Jenkins, Distribution of autoelectronic emission from single crystal metal points. Part $I$. Tungsten, molybdenum, nickel in the clean state. Proc. Roy. Soc., London, A176, 262-279 (1940).

4008 C. Kenty, Rugged quartz membrane manometers of sma11 volume. 16 references. Rev. Sci. Inst. 11, 377-386 (1940).

4009 E. J. Lawton, More about vacuum leak testing. Rev. Sci. Inst. 11, 134 (1940).

4010 H. J. H. Mol1 \& H. C. Burger, Thermoelectric vacuum gage. In German. Zt. tech. Phys. 21, 199-203 (1940).

4011 A. 0. Nier, A mass spectrometer for routine isotope abundance measurements. Rev. Sci. Inst. 11, 212-216 (1940).

4012 C. Weiss \& H. Westmeyer, A simple vacuum gage. In German. Zt. Instrumentenk. 60, 53-54 (1940).

4013 R. R. Sullivan \& K. L. Herte1, Flow of air through porous media. J. App1. Phys. 11, 761-765 (1940).

4014 K. J. Laidler, S. Glasstone \& H. Eyring, Application of the theory of absolute reaction rates to heterogeneous processes. I. The adsorption and desorption of gases. J. Chem. Phys. 8, 659-667 (1940).

4015 I. Langmuir, Monolayers on solids. J. Chem. Soc. p. 511-543 (1940).
4016 S. von Friesen, Large molecular pumps of the disk type. Rev. Sci. Inst. 11, 362-364 (1940)

4017 H. Schwarz, The mechanism of electronic clegn-up of gases at pressures below about $10^{-4}$ Torr. In German. Zt. Phys. 117, 2340 (1940).

4018 H. D. Hagstrum \& J. T. Tate, On the thermal activation of the oxygen molecule. Phys. Rev. 57, 1071 (1940).

4019 H. F. Baird \& C. J. Banwe11, Recording of air-pressure oscillations associated with microseisms at Christchurch. N. Z. J. Sci. Techn. 21, 314B-329B (1940).

4101 H. Weidemann, Theory of the ring manometer. In German. Luftfahrtfors chung 18, 223-229, (1941).

$$
\text { Hianonam }
$$

x 4102 W. E. Parkins \& W. A. Honization gage circuit with a magic eye. Rev. Sci. Insts. 12, 366-367 (1941).

4103 L. N. Ridenour, Magic eye ionization gage. Rev. Sci. Insts. 12, 134-136 (1941).

4104 R. W. Ditchburn \& J. C. Gilmour, Vapor pressures of monotomic vapors. Rev. Modern Phys. 13, 310-327 (1941).

4105 W. Bartholomyczyk, Thermoelectric method of measuring pressure. In German. Zt. tech. Phys. 22, 25-27 (1941).

4106 K. S. Rao, Hysteresis in sorption. III. Permanance and scanning of the hysteresis loop. Silica gel-water system. J. Phys. Chem. 45, 513-517 (1944).

4107 S. Hukagawa \& J. Nambo, Adsorption properties of metallic zirconium for gases and its applications. Electrotech. J., Japan, $\underline{5}$, 27-30 (1941).

4108 W. H. Keesom \& J. Schweers, Measurements of hydrogen adsorption on glass. Physica 8 , 1007-1019 (1941)

4109 พ. H. Keesom \& J. Schweers, Measurements of helium and neon adsorption on glass. Physica 8 , 1020-1031 (1941).

4110 W. H. Keesom \& J. Schweers, Measurements of helium on solidified layers of some gases. Physica 8, 1032-1043 (1941).

4111 B. Gutenberg \& H. Benioff, Atmospheric-pressure waves near Passadena. Trans. Am. Geophys. Union 22, 424-426 (1941).

4112 N. G. Keevil, R. F. Errington \& L. T. Newnam, The use of the McLeod gauge in measuring volumes. Rev. Sci. Inst. 12, 609-611 (1941). 
4201 J. E. De Graaf and H. C. Hamaker, The sorption of gases by barium. Physica 9, 297309 (1942).

4202 R. B. Ne1son \& A. K. Wing, Emission regulating circuit for an ionization gage. Rev. Sci. Insts. 13, 215-217 (1942).

4203 J. H. Danie1, Field emission from tungsten and thoriated tungsten single crystals. Phys. Rev. 61, 657-667 (1942).

4204 E. Wichers, Pure mercury. Chem. Eng. News 20, 1111 (1942).

4205 M. H. Armbruster, The adsorption of gases at low temperature and pressure on smooth silver. J. Am. Chem. Soc. 64, 2545-2553 (1942).

4206 E. A. Gulbransen, Some observations on the formation and stability of oxide films. 24 references. Trans. Am. Electrochem. Soc. 82, 375-387 (1942).

4207 R. Jaecke1, Application of organic oils for diffusion pumps and a new design of oil diffusion pump. In German. Zt. tech. Phys, 23, 177-186 (1942).

4208 W. A. Wildhack \& V. H. Goerke, The limiting deflections of corrugated metal diaphragms. Nat1. Advisory Comm. Aeronaut. Tech. Note No. 876,47 p. (1942).

4301 F. Kirby, A tilting oil McLeod gage. Atom. Energy Comm. AECD2673, 5 p. (1943).

4302 L. B. Thomas \& F. 01mer, The accommodation coefficients of $\mathrm{He}, \mathrm{Ne}, \mathrm{A}, \mathrm{H}_{2}, \mathrm{D}_{2}, \mathrm{O}_{2}, \mathrm{CO}_{2}$ and $\mathrm{Hg}$ on platinum as a function of temperature. 20 references. J. Am. Chem. Soc. 65 , 1036-1043 (1943).

4303 F. E. E. Germann \& K. A. Gagos, Accurate low-pressure gage. Ind. Eng. Chem., Anal. Ed. 15, 285-286 (1943).

4304 A. Rostagni, Universal vacuum meter. In Italian. Ricerca Sci. 14, 416-421 (1943).

4305 G. Burrows, Notes on high-vacuum technique. J. Sci. Inst. 20, 21-28 (1943).

4306 G. Haase, A McLeod gage with high accuracy and sensitivity. In German. $\mathrm{zt}$. tech. Phys. 24, 27-34 (1943).

4307 E. Weise, Semiconductor type gage for meas uring high and low gas pressures. In German. Zt. tech. Phys. 24, 66-69 (1943).

4308 L. A. Wooten \& C. Brown, Surface area of oxide coated cathodes by adsorption of gas at low pressures. J. Am. Chem. Soc. 65, $113-118$ (1943).
4309 G. Haase, On the measurement of very low pressures with a McLeod gage. In German. Zt. tech. Phys. 24, 53-55 (1943).

4401 I. Amdur, M. M. Jones \& H. Pear1man, Accommodation coefficients on gas covered platinum. J. Chem. Phys. 12, 159-166 (1944).

4402 0. Klemperer, Prevention of capillary dis turbances in electrolytic field plotting troughs and in McLeod gages. J. Sci. Insts. 21,88 (1944).

4403 K. M. Simpson, Philips type vacuum gauge. Univ. Calif. Rad. Lab. Report No. RL20.6.19 (1944).

4404 L. F. Wouters, The characteristics of Philips-type gauges. Univ. Calif. Rad. Lab. Report No. RL20.6.18 (1944).

4405 H. Schwarz, Gettering by ionization gages. In German. Zt. Phys. 122, 437-450 (1944).

4406 S. Weber, On the theory of radiometers and Knudsen's radiometer force. In German. K. Danske Vidensk Se1sk 21, No. 1, 57 p. (1944).

4407 H. Klumb \& H. Schwarz, On an absolute vacuum gage. In German. Zt. Phys. 122, 418436 (1944).

4408 J. L. v. Eichborn, Mutual adhesion of substances not miscible spatially. II. Evidence of adhesion in condensed moisture and hysteresis of the borderline of water drops on mercury surfaces. Kolloid-Zt. 109, 6278 (1944).

4409 H. Veith, Determination of the thickness of water films adhering to glass. Zt. Phys. Chem. 193, 378-385 (1944).

4410 W. G. Frankenburg, The adsorption of hydrogen on tungsten. I. \& II. J. Am. Chem. Soc. $66,1827-1847$ (1944).

4411 H. K. Livingston, Cross-sectional areas of molecules adsorbed on solid surfaces. J. Am. Chem. Soc. 66, 569-573 (1944).

4412 R. M. Barrer \& D. A. Ibbitson, 0cclusion of hydrocarbons by chabazite and analcite. Trans. Faraday Soc. 40, 195-206 (1944).

4413 R. M. Barrer, Sorption by gmelinite and mordenite. Trans. Faraday Soc. 40, 555564 (1944).

4414 K. C. D. Hickman, High-vacuum short-path distillation--a review. 110 references. Chem. Reviews 34, 51-106 (1944). 
4415 Anonymous, Getting and getters. Light metals, 7,34-52, 77-94 (1944).

4416 F. J. Norton \& A. L. Marsha11, The degassing of metals. Trans. Am. Inst. Mining \& Met. Eng. 156, 351-371 (1944).

4501 L. Saxer, Electrical measurements of small variations in atmospheric pressures. He1vetica Physica Acta $18,527-550$ (1945).

4502 E. W. Flosdorf, Water vapour and the McLeod type of vacuum gauge. Ind. Eng. Chem. Anal. Ed. 17, 198-199 (1945).

4503 S. Dushman \& A. H. Young, Calibration of ionization gauge for different gases. Phys. Rev. 68, 278 (1945).

4504 G. L. H. Jonker \& B. D. H. Te1legen, The current to a positive grid in electron tubes. Phillips Research Reports 1, 13-32 (1945-46).

4505 H. Nelson, The hydrogen gauge--an ultrasensitive device for location of air leaks in vacuum-device envelopes. Rev. Sci. Inst. 16, 273-275 (1945).

4506 R. B. Nelson, An a. c. operated leak detector and ionization gauge. Rev. Sci. Inst. 16, 55-57 (1945)

4507 R. A. Beebe, J. B. Beckwith \& J. M. Honig, The determination of sma11 surface areas by Krypton adsorption at low temperatures. J. Am. Chem. Soc. 67, 1554-1558 (1945).

4508 P. H. Emmett, Gas adsorption methods for measuring surface area of adsorbents. 24 references. Ind. Eng. Chem. 37, 639-644 (1945).

4509 A. G. Foster, The sorption of condensable vapours by porous solids. III. Multimolecular adsorption. J. Chem. Soc. p. 769-773 (1945).

4510 R. E. Honig, Gas flow in the mass spectrometer. J. App1. Physics 16, 646-654 (1945).

4511 R. Witty, High vacuum pumps. J. Sci. Inst. 22, 201-206 (1945).

4601 H. G. East \& H. Kuhn, Accurate be11ows manometer. J. Sci. Inst. 23, 185 (1946).

4602 M. H. Armbruster, The sorption of water vapor at low pressure on the surface of some cold-rolled steels at $20^{\circ} \mathrm{C}$. J. Am. Chem. Soc. 68, 1342-1347 (1946).

4603 E. S. Rittner, A Pirani gage for use at pressures up to $15 \mathrm{~mm}$. Rev. Sci. Inst. 17, 113-114 (1946).
4604 E. D. Hart \&. H. Elkin, Welding fine thermocouple wires. J. Sci. Inst. 23, 17-18 (1946).

4605 R. G. Picard, P. C. Smith, \& S. M. Zo1lers, A reliable high-vacuum gauge and zontro' system. Rev. Sci. Inst. 17, 125-129 (1946).

4606 R. J. Webber \& C. T. Lane, An easily constructed all-metal vacuum gage. Rev. Sci. Inst. 17, 308 . (1946).

4607 A. H. King, Ionization gauge contro1 unit. J. Sci. Insts. 23, 85 (1946).

4608 J. R. Downing \& G. Me11on, A sensitive vacuum gauge with linear response. Rev. Sci. Insts. 17, 218-223 (1946).

4609 G. L. Mellen, Radium-type vacuum gage. Electronics 19, Apri1, 142-146 (1946).

4610 N. Cabrera \& J. Terrien, Time lag of a Knudsen manometer incorporating an oscillatory system. In French. Rev. Sci., Paris, 84, 224-226 (1946).

4611 S. E. Williams, A Knudsen absolute manometer. J. Sci. Insts. 23, 144-146 (1946).

4612 H. Robinson \& M. C. Flanagan, Thermocouple vacuum gage. Gen. Elect. Rev. 49, 42-44 (1946).

4613 G. P. Brown, A. DiNardo, G. K. Cheng \& T. K. Sherwood, The flow of gases in pipes at low pressures. J. App1. Phys. 17, 802-813 (1946).

4614 A. Bobenrieth, Ionization gage for vacuum measurement. In French. Le Vide, 1, 61-64 (1946).

4615 K. E. Barr \& V. J. Anhorn, Scientific glass blowing techniques. $X$. Vacuum gages. 20 references. Instruments $19,666-680,734$ 746 (1946).

4616 C. M. Foge1, An ionization gauge of simple construction. Proc. Inst. Radio Eng. 34, 302-304 (1946).

4617 E. A. Hamacher, An automatic ionization vacuum gauge and monitor. Rev. Sci. Inst. 17, 281 (1946).

4618 H. A. Thomas, T. H. Killiams \& J. A. Hipple, A mass spectrometer type of leak detector. Rev. Sci. Inst. 17, 368-372 (1946).

4619 H. E. Van Valkenburg, Application of the ion gage in high vacuum measurement. Gen. Elect. Rev. 49, 38-42 (June 1946).

4620 W. G. Worcester \& E. G. Doughty, High vacuum leak testing with the mass spectrometer. Trans. Am. Inst. Elect. Eng. 65, 946-955 (1946). 
4621 P. Alexander, The theory of the mercury vapour vacuum pump and a new high-speed pump. J. Sci. Inst. 23, 11-16 (1946).

4622 I. Estermann, Molecular beam technique. 69 references. Rev. Mod. Phys. 18, 300-323 (1946).

4623 R. C. Jones \& W. H. Furry, The separation of isotopes by thermal diffusion. Rev. Modern Phys. 18, 151-224 (1946).

4624 M. L. Wiedmann \& P. R. Trumpler, Therma1 accommodation coefficients. Trans. A.S.M.E. 68, 57-64 (1946).

4625 C. Kembal1, on the surface tension of mercury. Trans. Faraday Soc. 42, 526-537 (1946).

4626 J. A. Becker, C. B. Green \& G. L. Pearson, Properties and uses of thermistors. Trans. Am. Inst. Elect. Eng. 65, 711-725 (1946).

4627 J. W. Hodgins, E. A. Flood \& J. R. Dacey, The flow of gases and vapors through media. Can. J. Research, 24B, 167-177 (1946).

4628 C. Kemba11 \& E. K. Rideal, The adsorption of vapors on mercury. I. Nonpolar substances. Proc. Roy. Soc., London A187, 53-73 (1946).

4629 G. D. Yarnold, The hysteresis of the angle of contact of mercury. Proc. Phys. Soc., London 58, 120-125 (1946).

4630 H. M. Carlson, Adjustable-range sensitive draft gage. Instruments $19,134-135$ (1946).

4631 L. Pauling, R. E. Wood \& J. H. Sturdivant, An instrument for determining the partial pressure of oxygen in a gas. J. Am. Chem. Soc. 68, 795-798 (1946).

4632 P. Tarbes, Improvement of McLeod gage. In French. Le Vide 1, 9-11 (1946).

4701 J. C. Lilly, V. Legallais \& R. Cherry, A variable capacitor for measurement of pressure and mechanical displacement; a theoretical analysis and its experimental evaluation. J. App1. Physics 18, 613-628 (1947).

4702 H. R. Hindley, A direct-reading differential micromanometer. J. Sci. Inst. 24, 295-297 (1947).

4703 Naval 0rd. Lab., Microbarometric waves from Helgoland "Big Bang". Naval Ord. Lab. Report No. 107049 p. (1947).

$4704 \mathrm{H}$. Von Ubisch, An investigation on hot-wire vacuum gauges. 43 references. Arkiv $f$. Mat. Astro. och Fysik 34A, No. 1433 p. (1947).
4705 C. Kenty \& F. W. Reuter, An apparatus for micro gas analysis. Rev. Sci. Inst. 18, 918-924 (1947).

4706 J. W. Tills, J. B. Lovatt, \& J. F. C. Potts, Improvements in pressure gages. British Patent No. 589,176 (1947). Provisiona1 specifications. No. 9234 (1944), 14037 (1944), 19307 (1944), 4909 (1945).

4707 J. Tills \& F. C. Potts, Improvements in vacuum gages. British Patent No. 592,379 (1947).

4708 J. Blears, Measurement of the u1timate pressures of oil-diffusion pumps. Proc. Roy. Soc., London A188, 62-76 (1947).

4709 C. G. McI1wraith, Starter for cold cathode ionization gauges. Rev. Sci. Insts. 18, 683 (1947).

4710 S. Weber, Investigation of the effect of accommodation coefficients on radiometers and molecular manometers. In German. K. Danske Vidensk Se1sk. 24, No. 4, 59 p. (1947).

4711 A. Rostagni \& I. Filosofo, Compensating radiometric vacuum meter. In Italian. Nuovo Cimento 4, 74-84 (1947).

4712 D. R. Stul1, Vapor pressure of pure substances. Organic and inorganic compounds. 965 references. 1500 compounds. Ind. Eng. Chem. 39, 517-550 (1947).

4713 R. B. Jacobs \& H. F. Zuhr, New developments in vacuum engineering. J. Appl. Physics 18 , 34-48 (1947).

4714 W. A. Wey1, Chemical aspects of some mechanical properties of glass. Research $\underline{1}, 50-$ 61 (1947).

4715 W. P. Dryer, Calculations for high vacuum systems. Chem. Eng. 54, 127-131, Nov., 122124, Dec. (1947).

4716 h. S. Young \& R. C. Taylor, Vacuum micromanometer. Ana1. Chem. 19, 133-135 (1947).

4717 B. V. Deryagin, V. I. Gol'danskii \& B. V. Karasev, Multimolecular adsorption and condensation of vapor on glass as studied by optical methods. Doklady Akad. Nauk S. S. S. R. 57, 697-700 (1947) .

4718 C. Kemba11, The adsorption of vapours on mercury, III. Polar substances. Proc. Roy. Soc., London A190, 117-137 (1947).

4719 B. B. Dayton, Standardization and sensitivity of ionization gages. In French. Le Vide 2, 349-355 (1947).

4720 J. E. Brow \& F. A. Schwertz, Simple micromanometer. Rev. Sci. Inst. 18, 183-186 (1947). 
4721 A. J. Ede, Use of McLeod gauge with a mixture of gas and vapour. J. Sci. Inst. 24, 198-199 (1947).

4722 N. F. Mott, The theory of the formation of protective oxide films on metals. III. Trans. Faraday Soc. 43, 429-434 (1947).

4723 W. Gaede, Gas ballast pumps. In German. Zt. Naturf. 2A, 233-238 (1947).

4801 A. S. Halliday, A distant reading manometer with particular application to the measurement of small pressures. Aero. Res. Comm. Grt. Brit. Reports and Memoranda R M No. 2744, 5 p. (1948)

4802 A. E. Cameron \& D. F. Eggers, An ion velocitron. Rev. Sci. Inst. 19, 605-606 (1948).

4803 H. Matheson \& M. Eden, A highly sensitive differential manometer. Rev. Sci. Inst. 19, 502-506 (1948).

4804 P. Romann, The inherent errors in the readings of a McLeod gage. In French. Le Vide $\underline{3}, 522-530$ (1948).

4805 C. M. Schwartz \& R. Lavender, A stable Pirani-gauge circuit for indication and control of vacuum equipment. Rev. Sci. Inst. 19, 814-815 (1948).

$4806 \mathrm{H}$. Von Ubisch, An investigation on hot-wire vacuum gauges. III. Arkiv. f. Mat. Astro. och Fysik, 36A, No. 4, 14 p. (1948); Nature 161,927 (1948).

4807 R. R. Legau1t, B. Makower \& W. F. Ta1burt, Apparatus for measurement of vapor pressure. Ana1. Chem. 20, 428-430 (1948).

4808 L. Apker, Surface phenomena useful in vacuum techniques. Ind. Eng. Chem. 40, 846-847 (1948).

4809 R. I. Garrod \& K. A. Gross, A combined thermocouple and cold-cathode vacuum gauge. J. Sci. Insts. 25, 378-383 (1948).

4810 H. I. S. A11wood, Vacuum protection system for oil diffusion pumps and thermionic filaments. J. Sc1. Insts. 25, 207-208 (1948).

4811 L. Apker, E. Taft \& J. Dickey, Energy distribution of photoelectrons from polycrysta11ine tungsten. Phys. Rev.73,46-50 (1948).

4812 J. H. Martin, Adjustable glass capillary gas leak. Rev. Sci. Inst. 19, 404-405 (1948).

4813 P. Alexander, The glycerol vapour vacuum pump. J. Sci. Inst. 25, 313-314 (1948).

4814 W. C. White \& J. S. Hickey, Electronics simulates sense of sme11. Electronics 21 . 100-102 (March, 1948).
4815 R. H. Savage \& C. Brown, Chemical and physical adsorption of gases on carbon dust. J. Am. Chem. Soc. 70, 2362-2366 (1948).

4816 B. B. Dayton, Measurement and comparison of pumping speeds. 32 references. Ind. Eng. Chem. 40, 795-803 (1948).

4817 R. Neumann, High vacuum pumps. I. Ear1y types. II. Modern developments. III. Diffusion pumps. IV. Diffusion pump design. V. Conclusion. 148 references. Electronic Eng. 20, 3-8, 44-48, 79-82, 122-125, 163$167(\overline{19} 48)$.

4818 C. E. Norman, Design of high vacuum systems Ind. Eng. Chem. 40, 783-787 (1948).

4819 H. M. Sullivan, Vacuum pumping equipment and systems. Rev. Sci. Inst. 19, 1-15 (1948).

4820 B. B. Dayton, The speed of oil and mercury diffusion pumps for hydrogen, helium and deuterium. Rev. Sci. Inst. 19, 793-804 (1948).

4821 E. A. Gulbransen \& H. S. Wysong, Thin oxide films on tungsten. 27 references. Am. Inst. Mining \& Met. Eng., Inst. of Metals Div. 175, 611-627 (1948).

4822 C. Kemba11, E. K. Rideal \& E. A. Guggenheim, Thermodynamics of monolayers. Trans.Faraday Soc. 44, 948-954 (1948).

4823 R. I. Razouk \& A. S. Salem, The adsorption of water vapor on glass surfaces. J. Phys. \& Co1loid. Chem. 52, 1208-1227 (1948).

4824 G. W. Monk, Apparatus for weighing in vacuum. J. App1. Phys. 19, 485-486 (1948).

4825 J. A. H. Kersten, On the relation between the thermal conductivity of rarified gases and the sensitivity range of Pirani gauges. Physica 14, 567-568 (1948).

4826 R. W. Makinson \& P. B. Treacy, An ionization manometer of high sensitivity. J. Sci. Inst. 25, 298-299 (1948).

4827 R. W. Asmussen \& B. Buchmann-01sen, A note on the absolute manometer. Trans. Danish Acad. Tech. Sci. No. 6, 8 p. (1948).

4828 G. L. Me11en, New techniques in the measurement of pressures below $10 \mathrm{~mm}$. Ind. Eng. Chem. 40, 787-791 (1948).

4829 I. E. Puddington, A sensitive mercury manometer. Rev. Sci. Inst. 19, 577-579 (1948).

4901 R. R. Cyr, A 16-point Pirani gage recorder. Univ. California, Eng. Dept. Berkeley, Report He-150-53; N7-ONR-295 Task 3 (Feb. $28,1949)$. 
4902 E. F. Cox, J. V. Atanasoff, B. I. Snavely, D. W. Becker \& J. Brown, Upper-atmosphere temperature from Helgoland big bang. J. Meteoro. 6, 306-311 (1949).

4903 L. Dunoyer, Study of the thermal vacuum gage. In French. Comptes Rendus 228, 372-374, 471-473 (1949); Le Vide $\underline{4}, \overline{571}-584$; 603$618 ; 643-660$ (1949).

4904 F. M. Penning \& K. Nienhuis, Construction and application of a new design of the Philips vacuum gauge. Philips Tech. Rev. 11, 116-122 (1949).

4905 E. A. Gulbransen \& K. F. Andrews, Kinetics of the reactions of zirconium with $\mathrm{O}_{2}, \mathrm{~N}_{2}$, and $\mathrm{H} 2.34$ references. Trans. Am. Inst. Mining \& Met. Eng., J. Metals 185, 515-525 (1949).

4906 G. Herrmann \& 0. Krieg, The effect of gases and vapors on the emission from oxycathodes. In German. Ann. Phys. Leipzig 4, 441-464 (1949).

4907 C. Hayashi, K. Hashimoto, et a1, Several improvements on the Philips gauge. Rev. Sci. Insts. 20, 524-526 (1949).

4908 P. Leduc, Precautions to be taken in the use of the Philip's gauge. In French. Le Vide $\underline{4}, 684(1949)$.

4909 G. C. Fryburg \& J. H. Simons, A precision vacuum gauge. Rev. Sci. Insts. 20, 541548 (1949).

4910 C. H. Bachman, A new principle in contro1led vacuum leaks. Rev. Sci. Inst. 20, 219-220 (1949).

4911 J. Groszkowski, A McLeod gauge of multiple compression. In French. Le Vide $\underline{4}, 668-$ 672 (1949).

4912 T. Hibi \& K. Isikawa, On the method of determining the best operating condition of a fractionating oil diffusion pump. Sci. Rep., Res.Inst. Tohoku Univ.A1,261-265(0ct.1949).

4913 E. A. Gulbransen \& K. F. Andrews, Kinetics of the reactions of titanium with $\mathrm{O}_{2}, \mathrm{~N}_{2}$ and $\mathrm{H}_{2} .48$ references. Trans. Am. Inst. Mining \& Met. Eng., J. of Metals 185, 741748 (1949).

4914 W. M. Hickam, Design for a metal mass spectrometer tube. Rev. Sci. Inst. 20, 472-474 (1949).

4915 G. Haase, Wetting of glass surfaces. Glastech. Ber. 22, 262 (1949).

4916 B. L. Harris \& P. H. Emmett, Adsorption studies. Physical adsorption of nitrogen, toluene, benzene, ethyliodide, hydrogen sulphide, water vapor, carbon disulphide and pentane on various porous, nonporous solids. J. Phys. \& Co11oid Chem. 53, 811-825 (1949).
4917 M. Seddig \& G. Haase, Experimental investigations of the critical condensation temperature. Kolloid-2t. 114, 169-174 (1949).

4918 C. J. Milner, Ionization gauge pressure switch. J. Sci. Inst. 26, 159 (1949).

4919 J. S. Nisbet, A pressure controller sensitive to $10^{-4} \mathrm{~mm}$ of mercury. J. Sci. Inst. 26 , 271-273 (1949).

4920 E. A. Gulbransen \& H. F. Andrews, Mullite and $z$ ircon furnace tubes for high temperature and high vacuum systems. Ind. Eng. Chem. 41, 2762-2767 (1949).

4921 G. Briegleb, Baro-photometer for measuring sma11 differential pressures. In German. Chemie-Ing.-Technik 21, 6-8 (1949).

4922 R. Comolet, New method of recording the position of a meniscus. Comptes Rendus 229, 867-868 (1949).

4923 J. A. H. Kersten \& H. Brinkman, Construction and theoretical analysis of direct reading hot-wire vacuum gauge with zero point contro1. App1. Sci. Research A1, 289-305 (1949).

4924 N. Cabrera, On the oxidation of metals at low temperatures and the influence of light. Phil. Mag. 40, 175-188 (1949).

5001 A. P. Crary, Stratosphere winds and temperature from acoustical propagation studies. J. Meteoro. 7, 233-242 (1950). AF Camb. Res. Lab., Geophys. Res. Paper No. 5 (1950).

5002 R. Havens, R. Ko11 \& H. LaGow, A new vacuum gage. Rev. Sci. Insts. 21, 596-598 (1950).

5003 J. E. Johnston, A demountable tetrode ionization gauge. Atom. Energy Res. Estab1. Grt. Brit. Report No. G/R 480 (1950).

5004 A. H. Turnbu11, Experiments with a differential Pirani gauge leak detector. At. Energy Res. Estab1. Grt. Br., Report No. AERE G/R 477, 9 p. (Mar. 1950).

5505 E. Wenk, Jr., A diaphragm-type gage for measuring low pressures in fluids. D. Taylor Mode1 Basin Report No. 66515 p. (1950).

5006 M. Axelbank, A rotary McLeod gage. Rev. Sci. Inst. 21, 511-513 (1950).

5007 W. Franzen \& J. Horton, A reliable Pirani vacuum safety circuit. Rev. Sci. Inst. 21 , 935 (1950).

5008 E. Blasco \& L. Miranda, A new Pirani type vacuum gauge. Rev. Sci. Inst. 21, 494-495 (1950).

5009 S. Wagener, A method of measuring the efficiency of getters at low pressures. British J. Applied Physics 1, 225-231 (1950) . 
5010 W. Espe, W. Knol1, \& M. P. Wilder, Getter materials for electron tubes. 74 references. Electronics 23, 80-86 0ctober (1950).

5011 F. M. Ke11y, An all metal ionization gage. Rev. Sci. Inst. 21, 673-674 (1950).

5012 R. T. Bayard \& D. A1pert, Extension of the low pressure range of the ionization gauge. Rev. Sci. Insts. 21, 571-572 (1950).

5013 J. J. Lander, U1tra-high vacuum ionization manometer. Rev. Sci. Inst. 21, 672-673 (1950).

5014 W. Stecke1macher \& S. Van Der Meer, Automatic regulation of thermionic emission. J. Sci. Insts. 27, 189-191 (1950).

5015 M. Shepherd \& J. A. Hipple, Mass spectrometry. 79 references. Anal. Chem. 22, 2325 (1950).

5016 E. C. Evans \& K. E. Burmaster, A Philipstype ionization gauge for measuring of vacuum from $10^{-7}$ to $10^{-1} \mathrm{~mm} \mathrm{Hg}$. Proc. Inst. Radio Eng. 38, 651-654 (1950).

5017 C. P. Butler \& F. E. Carpenter, A motor for use in vacuum systems. Rev. Sci. Inst. 21, 103 (1950)

5018 J. W. Clark \& G. H. Witts, An automatic control of high vacuum systems. Electronics 23, 108-110 (June 1950).

5019 W. J. Clark, The telerecording of thickness, pressure flow and other physical quantities using a simple electromagnetic circuit. Trans. Soc. Instr. Techno1. 2, 18-45 (March 1950).

5020 Z. G. Deutsch \& F. Raib1e, Mass spectrometer for leak detection. Chem. Engg. 57, 279284 (1950).

5021 H. E. Duckworth, A large Dempster doublefocussing mass spectrograph. Rev. Sci. Inst. 21, 54-59 (1950).

5022 N. A. Eckstein, J. W. Fitzgera1d \& C. A. Boyd, A method of making glass-to-metal seals. Rev. Sci. Inst. 21, 398-399 (1950).

5023 R. I. Garrod, A low-impedance high vacuum valve. J. Sci. Instr. 27, 205 (1950).

5024 R. M. I1feld, A recording mass spectrometer. Instrumentation. (Minn.-Honeywe11 Reg. Co) 4, 20-22 (Spring 1950).

5025 J. T. Lloyd, An audible vacuum leak detector. J. Sci. Inst. 27, 76 (1950).

5026 L. K. Nash, Gas analysis. 358 references. Ana1. Chem. 22, 108-118 (1950).

5027 W. P. Ratchford \& M. L. Fein, An improved manostat and manometer. Ana1. Chem. 22, 838-839 (1950).
5028 L. Spiers \& W. P. Jo11y, The Pirani effect in a thermionic filament as a means of measuring low pressure. Brit. J. Appl. Phys. 1, 132-133 (1950).

5029 J. A. A11en \& J. W. Mitche11, The adsorption of gases on copper films. Discuss. Faraday Soc. No. 8, 309-314 (1950).

5030 Ch. Biguenet, The photo-absorption of a thin film of barium. In French. Le Vide 5, 831-836 (1950).

5031 R. Champeix, On the possibility of using the ionization of gas molecules for the production of low pressures. In French. Comptes Rendus 231, 40-42 (1950); Le Vide 5, 912-913 (1950).

5032 R. W. Cloud \& S. F. Philp, Vacuum tests of rubber, lead, and teflon gaskets and vinyl acetate joints. Rev. Sci. Inst. 21, 731$733(1950)$.

5033 L. Dunoyer, Formulae for the flow of gases in pipes at low pressures. In French. Le Vide $5,881-886$ (1950).

5034 I. Filosofo, M. Merlin \& A. Rostagni, Measuring low vapour pressure. In Italian. II Nuovo Cimento $\underline{7}, 69-75$ (1950).

5035 G. Haase, The gettering efficiency of thin barium films at low pressures. In German. Zt. angew. Phys. 2, 188-191 (1950).

5036 R. Henry, Measurement of the pumping speed of rotary pumps. In French. Le Vide 5 859-865 (1950).

5037 J. J. Hopfield, Glass variable microleaks for gases. Rev. Sci. Inst. 21, 671-672 (1950).

5038 S. Oyama, On the vapor flow in the diffusion pump. J. Phys. Soc., Japan 5, 192-197 (1950).

5039 J. W. A. van der Scheer, A universal power supply circuit for use with ionization gauges. Het PTT-Bedrijf, Holland 3 , 2429 (May 1950).

5040 G. W. Sears \& E. R. Hopke, An effective vacuum cut-off. Rev. Sci. Inst. 21,570 (1950).

5041 R. Witty, The characteristics of diffusion pumps. Brit. J. App1. Phys. 1, 232-237 (1950).

5042 H. D. Hagstrum \& H. W. Weinhart, A new porcelain rod leak. Rev. Sci. Inst. 21, 394 (1950).

5043 R. E. Halsted \& Alfred 0. Nier, Gas flow through the mass spectrometer viscous leak. Rev. Sci. Inst. 21, 1019-1021 (1950).

5044 R. E. Honig, A greaseless gas flow valve. Rev. Sci. Inst. 21, 1024-1025 (1950). 
5045 G. H. Jenks, A convenient leak for testing helium leak detectors. Rev. Sci. Inst. 21 , 674-675 (1950).

5046 L. Kerwin, A new type mass spectrometer. Rev. Sci. Inst. 21, 96-97 (1950).

5047 J. P. Molnar \& C. D. Hartman, Data on porcelain rod leak. Rev. Sci. Inst. 21, 394-395 (1950).

5048 A. B. Stewart, Degassing extended glass systems. Rev. Sci. Inst. 21, 258 (1950).

5049 R. I. Garrod \& R. A. Coyle, Multiple highvacuum valve unit. J. Sci. Inst. $27,228-$ 229 (1950).

5050 J. E. Stanworth, Nicke1-chromium-iron for sealing to glass. J. Sci. Inst. 282-284 (1950).

5051 A. S. Tberall, Permeability of glass wool and other highly porous media. J. Research, Nat. Bur. Stds. 45, 398-406 (1950). RP 2150.

5052 S. Nagaeda, Changes of glass surface by acidic gases. J. Japan. Ceram. Assoc. 50, 648$650(1950)$.

5053 F. Ayer, Suppressing mercury vapor in vacuum systems. Rev. Sci. Inst. 21, 496 (1950).

5054 G. H. Metson, Vacuum factor of the oxidecathode valve. Brit. J. App1. Phys. 1, 7377 (1950).

5055 F. D. Herner, An investigation of the possible use of the glow discharge as a means for measuring air flow characteristics. Rev. Sci. Inst. 21, 61-68 (1950).

5056 D. B. Spalding, Simple manometer for use in measuring low air velocities. J. Sci. Inst. 27, 310-312 (1950).

5057 W. H. Bennett, Radio frequency mass spectrometer. J. App1. Phys. 21, 143-149 (1950).

5101 D. Alpert, C. G. Matland \& A. 0. McCoubrey, A null-reading absolute manometer. Rev. Sci. Inst. 22, 370-371 (1951).

5102 V. H. Dibeler \& F. Cordero, Diaphragm-type micromanometer for use on a mass spectrometer. J. Research NBS 46, 1-4 (1951). RP 2167.

5103 M. L. Greenough \& W. E. Williams, An electronic circuit for measuring the displacement of pressure-sensitive diaphragms. J. Research, NBS 46, 5-10 (1951). RP 2168.

5104 J. M. Los \& J. A. Morrison, A sensitive differential manometer. Rev. Sci. Inst. 22, 805-809 (1951).
5105 H. Schwarz, Procedures and instruments for vacuum measurement. In German. 173 references. Arch. f. Tech. Mess. V1341-2,4 p. (Sept. 1951); V1341-3, 4 p. (Jan. 1952); V1341-4, 4 p. (March 1952); V1341-5, 4 p. (May 1952).

5106 G. H. Metson, The physical basis of the residual vacuum characteristics of a thermionic valve. Brit. J. App1. Physics 2, 46-48 (1951).

5107 S. Wagener, Efficiency and mechanism of barium getters at low pressures. Brit. J. App1. Physics 2, 132-138 (1951).

5108 P. A. Richards \& W. A. Tuthil1, A simple ion-gauge regulator. Rev. Sci. Insts. 22, 841-842 (1951)

5109 L. Riddiford, Notes on the ionization gage. 22 references. J. Sci. Insts. 28, 375-379

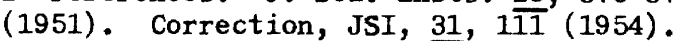

5110 0. A. Weinreich, Thermionic properties of incoated and thoria-coated rhodium and irdium cathodes. Phys. Rev. 82, 573 (1951).

5111 G. Gimenez \& J. Labeyrie, Vacuum gauge using alpha rays. In French. J. Phys. Radium 12, 64A -65A (1951).

5112 J. Blears, Application of the mass spectrometer to high vacuum problems. J. Sci. Insts. 28, Supp1. No. 1, p. 36-42 (1951).

5113 W. Steckelmacher, Review of vacuum gages. 65 references. J. Sci. Insts. 28, Supp1. No. 1, 10-19 (1951)

5114 J. Blears \& J. H. Leck, Genera1 principles of leak detection. 22 references. J. Sci. Insts. 28, Supp1. No. 1, 20-28 (1951).

5115 C. G. Milner, A cold-cathode mass spectrometer leak detector. J. Sci. Insts. 28, Supp1. No. 1, 29-36 (1951).

5116 L. Riddiford, The vacuum system of the Birmingham proton synchroton. J. Sci. Insts. 28, Supp1. No. 1, 47-58 (1951).

5117 R. Gomer, A nove1 method for the estimation of very low pressures. J. Chem. Phys. 19, 1072-1073 (1951)

5118 M. H. Mueller \& R. B. Bilinski, Sensitive leak control. Rev. Sci. Inst. 22, 704 (1951).

5119 H. Hinterberger, Experience with metal foil as high vacuum seals. In German. $\mathrm{Zt}$. Naturforsch. 6A, 459-462 (1951). Translation No. 2554, Atomic Energy Com.

5120 D. Alpert, Vacuum valve for the handling of very pure gases. Rev. Sci. Inst. 22, 536537 (1951). 
5121 H. Sommer, H. A. Thomas \& J. A. Hipple, The measurement of $\mathrm{e} / \mathrm{M}$ by cyclotron resonance. Phys. Rev. 82, 697-702 (1951).

5122 L. L. Katan, Vacuum-porder insulation for low temperatures. 13 references. Vacuum 1, 191-202 (1951).

5123 D. Latham, B. D. Power \& N. T. M. Dennis, Investigations into the ultimate pressures of diffusion pumps designed to purify their working fluids. Vacuum 1, 97-114 (1951).

5124 A. von Enge1, New trends in vacuum research based on ionization phenomena. 15 references. Vacuum 1, 257-265 (1951).

5125 W. Stecke1macher, Knudsen gauges. 48 references. Vacuum 1, 266-282 (1951).

5126 E. Eberhardt, H. Kern \& H. Klumb, Investigation of quartz fibers. In German. $\mathrm{zt}$. angew. Phys. 3 , 209-211 (1951).

5127 J. Blears \& J. H. Leck, Differential methods of leak detection. Brit. J. App1. Phys. 2, 227-232 (1951).

51.28 H. R. Dvorak \& R. N. Little, Jr., Interchangeable glass-to-metal seals for high vacuum work. Rev. Sci. Inst. 22, 1027-1028 (1951).

5129 W. A. Jenkins, A bubble counter for vacuum systems. Rev. Sci. Inst. 22, 845 (1951).

5130 C. Kenty, A new se1f-1ocking mercury cutoff. Rev. Sci. Inst. 22, 844-845 (1951).

5131 J. Stern, A vacuum valve for glass systems. Rev. Sci. Inst. 22, 702-703 (1951).

5132 F. P. Bowden \& J. E. Young, Friction of clean metals and the influence of adsorbed filins. Proc. Roy. Soc., London, 208A, 311325 (1951).

5133 M. Chiozzotto, Automatic pressure contro1 unit for high vacuum plant. In Italian. Nuovo Cimento 5 , 345-348 (1951).

5134 H. Ebert, Progress in vacuum technology in 1949-1950. In German. Glastech. Berichte 24, 152-157, 177-178 (1951).

5135 R. I. Garrod, A compact sliding vacuum seal. J. Sci. Inst. 28,187 (1951).

5136 R. Gilmont, Design and operational characteristics of Cartesian manostats. Anal. Chem. 23, 157-162 (1951).

5137 J. M. Go1dschwartz, A high-speed ionization gauge. In French. Le Vide 6, 955-956 (1951).

5138 K. Hickman, Reverse separation in fractionation pumps. Rev. Sci. Inst. 22, 141-146 (1951).
5139 R. B. Jacobs, The design of molecular pumps. Rev. Sci. Inst. 22, 217-220 (1951).

5140 C. Kenty, A McLeod gauge with an electrica1 contact. Rev. Sci. Inst. 22, 217-218 (1951).

5141 R. L. Longini, A high-speed hot baffle for oil diffusion pump systems. Rev. Sci. Inst. 22, 345-346 (1951).

5142 J. Romand, V. Schwetzoff \& B. Vodar, The absorption of ultraviolet light for detecting leaks and measuring pressure. In French. Le Vide 6 , 1046 (1951).

5143 E. Umblia, Meta1lising glass. Glass 28, 343-351 (1951).

$5144 \mathrm{~F}$. Hade, The measurement of high vacuum by electrical methods. Electronic Eng. 23, 30-34, Jan., 44-48, Feb. (1951).

5145 S. Wagener \& C. B. Johnson, Calibration of ionization gauges for variousgases at low pressures. J. Sci. Inst. 28, 278 (1951).

5146 R. M. Barrer \& D. M. Grove, Flow of gases and vapours in a porous medium and its bearing on adsorption problems. I. The steady state of flow. Trans. Faraday Soc. 47, 826-837 (1951).

5147 R. M. Barrer \& D. M. Grove, Flow of gases and vapours in a porous medium and its bearing on adsorption problems. II. Transient flow. Trans. Faraday Soc. 47, 837844 (1951).

5148 R. C. Dartne11, H. V. Fairbanks \& W. A. Koehler, Investigation of the adherence of glass to metals and alloys. J. Am. Ceramic Soc. 34, 357-360 (1951).

5149 D. R. Goddard, Modern vacuum pumps. J. Sci. Inst. 28, Supp1. 1, 1-7 (1951).

5150 B. Gutenberg, Sound propagation in the atmosphere. 30 references. Compendium of Meteorology, T. F. Malone, Editor, Am.Meteoro. Soc. 366-375 (1951).

5151 A. J. Madden, Jr. \& E. L. Piret, Heat transfer from wires to gases at subatmosphere pressures under natural convection conditions. Proc. Gen. Discuss. on Heat Transfer, Inst. Mech. Eng., Section 4 (1951).

5152 R. Meakin, Determination of mercury level in a stee1 tube manometer. J. Sci. Inst. 28 , 372-373 (1951).

5153 M. J. Reddan \& G. F. Rouse, Clean-up of helium gas in an arc discharge. Trans. Am. Inst. E1ect. Engs. 70, Pt. 2, 1924-1929 (1951). 
5154 M. E. Reinders, J. Schutten \& J. Kistemaker, Leak detection with a mass spectrometer using hydrogen gas. App1. Sci. Res. B2, 6670 (1951).

5155 L. Riddiford \& R. F. Coe, Leaks in vacuum 1iquid-air traps. J. Sci. Inst. 28, 352-353 (1951).

5156 H. Von Ubisch, On the conduction of heat in rarified gases and its manometric application. I. App1. Sci. Res. A2, 364-402 (1951).

5157 E. Volcker, A simple method of leak detection in high vacuum apparatus. In German. $\mathrm{Zt}$. Naturforsch. 6a, 512-513 (1951).

5158 H. Von Ubisch, On the conduction of heat in rarified gases and its manometric application. II. App1. Sci. Res. A2, 403-430 (1951).

5159 N. Warmoltz, On the application of a Philips ionization gauge type of oin source in a mass spectrometer leak detector. App1. Sci. Res. 2B, 61-65 (1951).

5160 C. G. Youngs, T. M. Ma11ard \& B. M. Craig, Photo-electric vacuum controller. Canad. J. Techn. 29, 447-450 (1951).

5161 J. A. Becker, The use of the field emission electron microscope in adsorption studies of $\mathrm{W}$ on $\mathrm{W}$ and $\mathrm{Ba}$ on $\mathrm{W}$. Be11 Syst. Tech. J. 30, 907-932 (1951).

5162 A. Kobayashi \& S. Furuya, Reactions of barium film with oxygen. I. J. Phys. Soc., Japan 6, 238-243 (1951).

5163 R. L. Sproul1, W. C. Dash, W. W. Tyler \& A. R. Moore, Growth and manipulation of barium oxide crystals. Rev. Sci. Inst. 22, 410-414 (1951).

5164 J. D. Babbitt, The diffusion of adsorbed gases through solids. Canad. J. Phys. 29, 437-446 (1951).

5165 G. Jura, The determination of surface area of the surfaces of solids. 71 references. Chapter in physical methods in chemical analysis, W. G. Ber1, Editor, Academic Press, p. 255-303 (1951).

5166 B. B. Dayton, Vacuum techniques and analysis. 227 references. Chapter in physical methods in chemical analysis, W. G. Ber1, Editor, Academic Press, P. 333-386 (1951).

5167 R. E. Peck, W. S. Fagan \& P. P. Werlein, Heat transfer through gases at low pressures. Trans. ASME 73, 281-287 (1951).
5201 R. J. Havens, R. T. Ko11 \& H. E. LaGow, The pressure, density and temperature of the earth's atmosphere to $160 \mathrm{~km}$. J.Geophys. Research, 57, 59-72 (1952).

5202 J. H. Leck, The high temperature Pirani gauge. J. Sci. Insts. 29, 258-263 (1952).

5203 A. E. J. Eggleton \& F. C. Tompkins, The thermal accommodation coefficient of gases and their absorption on iron. Trans. Faraday Soc. 48, 738-749 (1952).

5204 T. Arizumi \& S. Kotani, Gettering process of barium-sorption properties of oxygen to barium. J. Phys. Soc., Japan 7, 300-307 (1952).

5205 S. Hagener, The production of very high vacuum by the use of getters. Proc. Inst. Elect. Engineers, Grt. Brit. Part 3, 99, 135-147 (1952).

5206 J. H. Burrow \& E. W. J. Mitche11, The ionization gauge-two modifications. J. Sci. Insts. 29, 27-28 (1952).

5207 0. A. Weinreich \& H. Bleecher, Ionization gage with thoria-coated cathode. Rev. Sci. Inst. 23, 56 (1952).

5208 N. Karmoltz \& E. Bouwmeester, An easily degassable ionization gauge with a simple and stable circuit. App1. Sci. Research 2B, 273-276 (1952).

5209 A. H. Beck \& A. D. Brisbane, A cylindrical magnetron ionization gauge. Vacuum 2, 137146 (1952).

5210 C. N. W. Litting \& W. K. Taylor, An automatically-controlled Knudsen-type vacuum gauge. Proc. Inst. Elect. Eng. 99, Part IV, Monograph No. 36 (1952).

5211 S. C. Brown \& J. E. Coy1e, An al1-metal vacuum valve. Rev. Sci. Inst. $23,570-571$ (1952).

5212 E. W. Becker \& 0. StehI, Electrostatic differential manometer. In German. $\mathrm{Zt}$. angew. Phys. 4, 20-22 (1952).

5213 G. Burrows \& R. Jackson, Determination of the molecular weights of low vapour pressure oils and greases. Vacuum 2, 50-55 (1952).

5214 Anonymous, The $206 \mathrm{R}$ pressure transmitter. Taylor Technology 4 , No. 3, 17-19 (1952).

5215 G. Von Darde1 \& H. Von Ubisch, Hot wire manometers. Teknisk Tidskrift (Sweden) 82, 203-208 (1952).

5216 D. Degras, A thermocouple gage. In French. Le Vide I, 1153-1171 (1952).

5217 N. A. Florescu, Shunted thermocouple vacuum gage. J. Sci. Inst. 29, 298 (1952). 
5218 J. S. Foster, Jr. \& E. J. Lofgren, Ion pump. Vacuum 2, 257 (1952).

5219 J. S. Foster, Jr., E. 0. Lawrence \& E. J. Lofgren, A high vacuum high speed ion pump. Univ. Calif., Radiation Lab. Report No.UCRL 1930 (1952).

5220 W. F. Giauque, T. H. Geballe, D. N. Lyon \& J. J. Fritz, Some properties of plastics and the use of plastic apparatus at low temperature. Rev. Sci. Inst. 23, 169-173 (1952).

5221 F. A. Gould \& T. Vickers, Capillary depression in mercury barometers and manometers. J. Sci. Inst. 29, 85-87 (1952).

5222 A. G. Hayward, Simple vacuum seals. Vacuum 2, 262-264 (1952).

5223 K. C. D. Hickman, Studies in high vacuum evaporation. Surface behavior in the pot sti11. Ind. Eng. Chem. 44, 1892-1902 (1952).

5224 K. C. D. Hickman \& D. J. Trevoy, Studies in high vacuum evaporation. Comparison of high vacuum stills and tensimeters. Ind. Eng. Chem. 44, 1903-1911 (1952).

5225 K. Hickman \& D. J. Trevoy, Evaporation from liquid surfaces in vacuum. 16 references. Vacuum 2, 3-18 (1952).

5226 J. A. W. Huggil1, The flow of gases through capillaries. Proc. Roy. Soc., London, 212A, 123-136 (1952).

5227 H. G. Jensen, An investigation of a metal Knudsen manometer. Vacuum 2, 388-389 (1952).

5228 D. Latham, B. D. Power \& N. T. M. Dennis, An assessment of some working fluids for diffusion pumps. 20 references. Vacuum $\underline{2}$, $33-49$ (1952).

$5229 \mathrm{~J}$. B. Lawrence, Mercury the purest meta1. Instruments 25, 310-312 (1952).

5230 G. J. Maslach, A precision differential manometer. Rev. Sci. Inst. 23, 367-369 (1952).

5231 F. J. Miranda \& W. M. Jones, Vacuum sea1s for continuously evacuated accelerator tubes operating in high ambient pressure. Vacuum 2, 259-262 (1952).

5232 G. C. Moench, Improving the performance of glass Dewar flasks. In German. Glas- und Hochvakuum Tech. 1, 9-13 (1952).

5233 N. Ochert \& W. Steckelmacher, Leak detection practice with particular reference to the hydrogen palladium method. 71 references. Vacuum 2, 125-136 (1952).
5234 L. G. Parratt \& E. L. Jossem, Backstreaming in oil diffusion pumps. Rev. Sci. Inst. 23, 188-189 (1952).

5235 L. Riddiford, Comments on new trends in ionization phenomena. Vacuum 2, 151-152 (1952).

5236 M. Seddig \& G. Haase, Measurements of pressures below $10^{-7} \mathrm{~mm}$ of mercury by absorption. In German. Zt. angew. Phys. 4, 105-108 (1952).

5237 H. Sibata, Y. Tuzi \& H. Kumagai, A new circuit for ionization vacuum gauge. Rev. Sci. Inst. 23, 54-55 (1952).

5238 L. R. Sitney, A high speed rotary vacuum sea1. Rev. Sci. Inst. 23, 505-506 (1952).

5239 M. H. Stanier \& J. H. Beynon, A greaseless mercury-sealed vacuum tap. J. Sci. Inst. 29, 165-166 (1952).

5240 J. D. Strong, On a bakable evaporation apparatus. Vacuum 2, 111-114 (1952).

5241 H. Von Ubisch, Hot wire manometers for chemical applications. Ana1. Chem. 24, 931-938 (1952).

5242 M. J. Vermandé, The operation and performance of the Penning gauge. In French. Le Vide $7,1145-1152$ (1952).

5243 E. L. Wheeler, Apparatus for triple distillation of mercury. Anal. Chem. 24, 751-752 (1952).

5244 P. D. Zemany, Free molecular flow in the sample inlet to the mass spectrometer. J. App1. Phys. 23, 924-927 (1952).

5245 K. Ziock, Vacuum-measuring techniques. In German. Glas-und Hochvakuum Tech. 1, 5762 (1952).

5246 A. Boettcher, Glass surfaces in a high vacuum. In German. Glastech. Berichte 25, 347-353 (1952).

5247 E. A. Bunt \& R. J. McCulloch, The design of high vacuum systems. Part $\mathrm{I}$. \& II. Ind. Chem. 460-465, 503-508 (1952).

5248 W. E. Bush, Causes of failure of vacuum systems. Univ. Calif. Rad. Lab. Report No. UCRL-1887 (1952).

5249 W. E. Bush, Design of radiation-heated cathodes for ion pumps. Univ. Calif. Rad. Lab. Report No. UCRL-1929 (1952). 
5250 N. A. Florescu, A compression vacuum gauge with a large working range. Investigationes Physicae, No. 3, 4 p. (1952).

5251 G. Glockler \& H. V. Horst, The Pirani gauge. Science 116, 364-367 (1952).

5252 R. Jaecke1 \& H. G. Noeller, Vacuum pumps for pressures below one Torr. In German. Zt. Ver. Deut. Ing. 94, 797-803 (1952).

5253 R. Palme, Tungsten and molybdenum in vacuum engineering. In German. Glas-und-Hochvakuum Tech. 134-139 (Dec. 1952).

5254 P. A. Redhead, Stabilized ion gauge contro1 unit. Nat. Res. Council, Canada, Report No. ERB 275 (1952).

5255 H. Schwarz, Method of realizing high vacua by ionization. Design of electronic pump. In French. Le Vide 7, 1262-1266 (1952).

5256 J. R. Sites \& R. Baldock, Mass spectrometer studies of high vacuum materials. Atomic Energy Com. Report No. ORNL-1405 (1952).

5257 V. T. Slavianskii, on the conditions of the performance of an absolute mercury manometer. In Russian. Zhurnal Teknicheskoi Fiziki, Moscow, 22, 1881-1884 (1952).

5258 R. A. Wallace \& W. R. Vanderveer, Brazing vacuum-tight joints in high nickel alloys. Materials \& Methods 36, 117-118 (Dec. 1952).

5259 R. Gomer \& J. K. Hulm, Field emission from tantalum in the normal and superconducting state. J. Chem. Phys. 20, 1500-1502 (1952).

5260 J. J. Lander, H. E. Kern \& A. L. Beach, Solubility and diffusion coefficient of carm bon in nicke1; Reaction rates of nicke1carbon alloys with barium oxide. J. App1. Phys. 23, 1305-1309 (1952).

5261 F. J. Norton, Diffusion of gases through solids. Gen. Elect. Rev. 55, 28-29 (Sept. 1952).

5262 D. M. To1stoi, S.1ip of mercury on glass. Doklady Akad. Nauk SSSR 85, 1329-1332 (1952). Chem. Abstracts 47, 1450 (1953).

5263 L. Akobjanoff, A precise gas manometer. Rev. Sci. Inst. 23, 447-448 (1952).

5264 W. H. Bergmann, Observations on g1ow discharges on magnetic fields. In German. Acta Phys. Austriaca $\underline{5}, 425-428$ (1952).

5265 K. P. Coffin \& S. H. Bauer, Apparatus for imposing and measuring rapid pressure changes in gases. Rev. Sci. Inst. 23, 115118 (1952).

5266 0. Tsukakoshi, Calibration of Foge1-type and Bayard type ionization gauges. J. Tokyo Research Inst. 46, 247-254 (1952).
5267 G. Valle, Theory of the discharge potential of coaxial cylindrical electrodes in a transverse magnetic field. In Italian. Nuovo Cimento 9, 145-168 (1952).

5268 C. I. Witman, On the measurement of vapor pressures by effusion. J. Chem. Phys. 20, 161-163 (1952).

5269 W. Pupp, Practicality of an ionization vacuum gage. In German. Glas-und-Hochvakuum Tech. 1, 3-6 (1952).

5270 W. Pupp, Thermoelectric vacuum gage "Theva." Glas-und-Hochvakuum Tech. 1, 66-68 (1952).

5271 J. L. Patterson, Miniature electrical pressure gage utilizing stretched flat diaphragm Nat1. Advisory Comm. Aeronaut. Tech. Note No. 2659,47 p. (1952).

5272 R. A. Clark, T. I. Gilroy \& E. Reissner, Stesses and deformations of toroidal she11s of elliptical cross section. ASME J. App1. Mechanics 74, 37-44 (1952).

5273 W. Wuest, The influence of the cross-sectional form on the behavior of Bourdon tubes. Ingenieure Archiv 20, 116-125 (1952).

5301 I. G. Baxter, Differentia1 Capacitance Manometer. J. Sci. Inst. 30, 358-360 (1953).

5302 D. B. Cook \& C. J. Danby, A simple diaphragm micromanometer. J. Sci. Inst. 30, 238-240 (1953).

5303 W. H. Kaechle \&. G. Brombacher, Diaphragm type vacuum gage. N. B. S. Report No. 2621, 26 p. (1953).

5304 R. A. K. Long, An automatic micromanometer for the measurement of low air speeds. J. Sci. Inst. 30, 481-482 (1953).

5305 T. A. Per1s, W. H. Kaechle \& D. S. Goalwin, A diaphragm-type, capacitance-type micromanometer for very low differential pressures. N. B. S. Report No. 2165, 7 p.(1953).

5306 M. J. Pilny, A sma11 Pirani gage for measurements of nonsteady low pressures. Nat1. Advisory Comm. Aeronaut. Tech. Note TN 2946, 36 p. (1953).

5307 D. C. Pressey, Temperature-stable, capacitance pressure gauge. J. Sci. Inst. 30, 2024 (1953).

5308 S. Wagener, The use of getters for the production of very high vacuum. 19 references. Vacuum 3 , 11-23 (1953).

5309 R. N. Bloomer \& M. E. Haine, The electronic clean-up of gases in sealed-off vacuum systems. 14 references. Vacuum $3,128-135$ (1953). 
5310 D. Alpert, New developments in the production and measurement of ultra high vacuum. 37 references. J. App1. Phys. 24, 860-876 (1953).

5311 G. K. T. Conn \& H. N. Daglish, Cold cathode gauges for the measurement of low pressures. 24 references. Vacuum $3,24-34$ (1953).

5312 J. H. Leck, Sorption and desorption of gas in the cold-cathode ionization gage. J. Sci. Insts. 30, 271-274 (1953).

5313 J. A. Becker \& C. D. Hartman, Field emisston microscope and flash filament techniques for the study of structure and absorption on metal surfaces. J. Phys. Chem. 57, 153159 (1953).

5314 H. D. Hagstrum, Instrumentation and experimental procedure for studies of electron ejection by ions and ionization by electron impact. 26 references. Rev. Sci. Insts. 24, 1122-1142 (1953).

5315 H. Koenig, The formation of adsorbed layers in vacuum chambers and their detection by electrons. 15 references. Vacuum 3 , 310 (1953).

5316 F. L. Jones, Electrical discharges and the vacuum physicist. 28 references. Vacuum 3, 116-127 (1953).

5317 H. Klumb \& E. Weissmann, A new manometer for the pressure region $10^{-2}$ to $10^{-6} \mathrm{~mm} \mathrm{Hg}$ Glas-und-Hochvakuum Tech. 2, 266-269 (1953).

5318 H. K1umb \& H. Kollmannsperger, Research on the friction manometer. Glas-und-Hochvakuum Tech. 2, 211-213 (1953).

5319 K. D. Mielenz \& E. Schoenheit, On the theory of the quartz fibre manometer. $z t$. angew. Phys. 5, 90-94 (1953).

5320 J. Yarwood, Isolation values for vacuum systems. 33 references. Vacuum $3,398-$ 411 (1953).

5321 M. Michijima, Measurement of vapour pressures; some problems in vacuum techniques. Oyo Butsuri 22, 180-184 (1953).

$5322 \mathrm{H}$. Wesse1, Wettability of glass measured by contact-angle method. In German. Silikattech. 4, 59-63 (1953).

$5323 \mathrm{~J}$. S. Foster Jr., Some measurements on a high-vacuum high speed ion pump. Univ. Calf., UCRL Report No. 2312 (1953).

5324 E. F. Babelay \& L. A. Smith, A needle valve type of variable gas leak for mass spectrometers. Rev. Sci. Inst. 24, 508-510 (1953).

5325 J. Morrison, A leak contro1 tube. Rev. Sci. Inst. 24, 546-547 (1953).
5326 A. J. Stinnett, A vibrating needle variable gas leak. Rev. Sci. Inst. 24, 883-884 (1953).

5327 I. G. Baxter, A capacitance manometer of 1ow thermal sensitivity. J. Sci. Inst. $30,456-$ 457 (1953).

5328 F. S. Sherman, New experiments on impact pressure interpretation in supersonic and subsonic rarified gas streams. Nat1. Advisory Comm. Aeronaut. Tech. Note No. 2995, 73 p. (1953).

5329 G. A. Alers, J. A. Jacobs \& P. R. Malmberg, Increased sensitivity of leak detection with hydrogen. Rev. Sci. Inst. 24, 399-400(1953).

5330 D. Alpert, Copper isolation trap for vacuum systems. Rev. Sci. Inst. 24, 1004-1005 (1953).

5331 M. A. Biondi, 0il manometer for u1tra-high vacuum systems. Rev. Sci. Inst. 24, 989990 (1953).

5332 R. Forman, A vacuum valve to provide small controlled leak rates. Rev. Sci. Inst. 24 , 326-327 (1953).

5333 J. S. Foster, Jr., E. O. Lawrence \& E. J. Lofgren, A high vacuum high speed ion pump. Rev. Sci. Inst. 24, 388-390 (1953).

5334 G. H. Miller, Vacuum cold trap. Rev. Sci. Inst. 24, 549-550 (1953).

5335 J. Morrison, A contro1led gas 1eak. Rev. Sci. Inst. 24, 230-231 (1953).

5336 J. Po1lard, A conduction-cooled trap for demountable vacuum systems. Rev. Sci. Inst. 24, 996-997 (1953)

5337 D. H. Pringle \& R. M. Kidd, Improvements to a null-reading absolute manometer. Rev. Sci. Inst. 24, 877 (1953).

5338 E. G. Reil1y, A combination high-vacuum and pressure valve. Rev. Sci. Inst. 24, 875876 (1953).

5339 พ. W. Schriever, Jr., A double seal vacuum coupling. Rev. Sci. Inst. 24, 402-403 (1953).

5340 H. Schwarz, Methods of obtaining high vacuum by ionization. Construction of an "electronic pump. Rev. Sci. Inst. 24, 371-374 (1953). Error corrected, 25, $\overline{92} 4$ (1954).

5341 C. M. Stevens, A vacuum lock for routine solid analyses with a mass spectrometer. Rev. Sci. Inst. 24, 148-151 (1953).

5342 E. Tajima, K. Kaneko \& A. Katajama, Some characteristics of an oil ejector pump. Rev. Sci. Inst. 24, 323-325 (1953). 
5343 D. J. Trevoy \& W. A. Torpey, A vacuum anemometer. Rev. Sci. Inst. 24, 676-682(1953).

5344 R. Haefer, The breakdown voltages of gaseous discharges in transverse magpetic fields in the pressure range 10 to $10 \mathrm{~mm} \mathrm{Hg}$. In German. Acta Phys. Austriaca, 7, 52-90, 251277 (1953).

5345 M. J. Aitken, An electrical analogue to a high vacuum system. Brit. J. App1. Phys. $\underline{4}, 188(1953)$.

5346 S. Asao \& K. Muramatsu, A large unwelded vacuum gate valve. J. Sci. Inst. 30, 209210 (1953).

5347 A. Bobenrieth, A degassable Penning gauge. In French. Le Vide. 8 , 1302-1304 (1953).

5348 W. Duesing, Vacuum tight glass-to-metal seals for use in electrical engineering. In German. Glastech. Berichte 26, 232-238 (1953).

5349 G. Economos, Behavior of refractory oxides in contact with metals at high temperatures. Ind. Eng. Chem. 45, 458-459 (1953).

5350 F. J. Fitz 0sborne, A simplified ionization gauge circuit. Canad. J. Phys. 31, 11-14 (1953).

5351 W. L. Harries \& A. Von Enge1, A new electron multiplication process. Nature 171 , 517 (1953).

5352 E. R. Harrison, G1ass leak and control valves. J. Sci. Inst. 30, 170-171 (1953).

5353 K. Histake \& K. Matsuda, A study on diffusion pump oil by the mass spectrometer and the gas analysis of the final volume. J. Phys. Soc., Japan, 8, 416-421 (1953).

5354 E. L. Holland-Merten, H. Reuther \& S. S1iwinski, The use of silicone oil as an operating fuel for diffusion pumps. In German. Chem. Technik 5, 301-303 (1953).

5355 H. Ishii, U1timate pressure obtained by oil diffusion pump. 0yo Butsuri(J. App1. Physics, Univ. of Tokio) 22, 69-72 (1953).

5356 G. L. Kington \& J. M. Holmes, Adsorption by evaporated copper films at $78^{\circ} \mathrm{K}$. Part I. Krypton and hydrogen. Trans. Faraday Soc. $\underline{49}, 417-423$ (1953).

5357 G. L. Kington \& J. M. Holmes, Adsorption by evaporated copper films at $78^{\circ} \mathrm{K}$. Part 2. Krypton and oxygen. Trans. Faraday Soc. $\underline{49}, 425-432$ (1953).

5358 H. Klumb, E. Robens \& 0. Scholz, Supersonic speeds in high vacuum. In German. Naturwiss. 40, 196-197 (1953).
5359 E. R. Lind \& J. F. Steinhaus, Development of a large, linear jet, mercury diffusion pump having high pumping speeds in the $10^{-6} \mathrm{~mm}$ mercury absolute pressure range. Calif. Res. \& Dev. Co,; Atomic Energy Com. Report No. MTA-14 (1953).

5360 M. A. Miller \& A. S. Russe11, Vacuum tightness of welded and brazed aluminum containers. Welding J. 116-118 (Feb. 1953).

5361 A. 0. C. Nier, The mass spectrometer. Scientific Am. 68-74 (March, 1953).

5362 F. J. Norton, Helium diffusion through glass. J. Am. Ceramic Soc. 36, 90-96 (March, 1953).

5363 E. Thomas, Calculation of the rate of diffusion through a plate of palladium. In French. Soc. Roy. Belge Ing. Industr. Mem. 19-32 (1953).

5364 G. M. van Koppen, A metal vacuum valve. App1. Sci. Res. 3B, 141 (1953).

5365 G. von Darde1, Combined Pirani and ionization gauge circuit. J. Sci. Inst. 30, 114117 (1953).

5366 S. Wagener, Sorption of gases at very low pressures by thorium powder. Proc. Phys. Soc., London 66B, 400-413 (1953).

5367 R. Gomer \& J. K. Hulm, A method for studying the mobility of chemisorbed films: oxygen on tungsten. J. Am. Chem. Soc. 75, 4114-4115 (1953).

5368 H. D. Hagstrum, Electron ejection from Mo by $\mathrm{He}^{+}, \mathrm{He}^{++}$, and $\mathrm{He}_{2}+$. Phys. Rev. 89, 244-255 (1953).

5369 R. G. Herb, R. H. Davis, A. S. Divatia \& D. Saxon, Evapor-ion pump. (abstract). Phys. Rev. 89, 897 (1953).

5370 E. Thomas, J. Destappes \& J. Dupont, A stainless steel trap for a metal vacuum system. Vacuum $\underline{3}, 413$ (1953).

5371 L. M. Van der Py1, Bibliography on Bourdon tubes and Bourdon tube gages. Am. Soc. Mech. Eng., Paper No. 53-IRD-1, 22 p. (1953).

5372 0. Tsukakoshi, Device for evacuation in high vacuum. J. Sci. Research Inst., Tokyo, 47, 133-148 (1953).

5373 F. H. Reynolds, An electrical manometer for gas pressures up to $40 \mathrm{~mm}$ of mercury. J. Sci. Inst. 30, 92-96 (1953).

5374 พ. Harte1, Method for determing water vapor in vacuum apparatus. In German. Zt. Ver. Deut. Ing. 95, 215-218 (1953). 
5375 R. Uyeda \& Y. Sugiura, A flowmeter in vacuum technique. J. Phys. Soc., Japan 8, 99-103 (1953).

5376 S. M. Branson, A simple ion gauge stabilizer. Inst. Practice 7, 425-427 (1953).

5377 H. Klumb \& 0 . Heiligenbrunner, On the app1ication of the resonance manometer to vacuum measurement. In German. Glas-und-Hochvakuum Tech. 2, 269-271 (1953).

\section{0}

5378 G. Detre \& B. Schroeder, The application of the ionization gage for the measurement of periodic pressure fluctuations and rapid pressure changes. In German. Glas-undHochvakuum Tech. 2, 285-292 (1953).

5379 M. M. Wo1ff \& W. E. Stephens, A pulsed mass spectrometer with time dispersion. Rev. Sci. Inst. 24, 616-617 (1953).

5380 E. G. Johnson \& A. 0. Nier, Angular aberrations in sector shaped electromagnetic lenses for focusing beams of charged particles. Phys. Rev. 91, 10-17 (1953).

5381 S. Suzuki, Differential recorders of meteorological elements. Geophys. Mag. 24, 171179 (1953).

5401 R. A. Gross, Calibration of sensitive differential pressure devices. Rev. Sci. Inst. 25, 218-220 (1954).

5402 H. S. Sicinski, N. W. Spencer, \& W. G. Dow, Rocket measurements of upper atmosphere ambient temperature and pressure in the 30 to 75 kilometer region. J. App1. Physics 25, 161-168 (1954).

5403 J. H. Leck, A quartz-coated wire Pirani gauge. J. Sci. Inst. 31, 226-227 (1954).

5404 D. J. Santeler \& J. F. Norton, A graphical approach to vacuum engineering. Vacuum $\underline{4}$, 176-194 (1954).

5405 S. Wagener, Influence of electronic impact on the rate of sorption of gases onto getter materia1s. Nature 173, 684-685 (1954).

5406 S. Wagener, Relations between oxide cathodes and gases at very low pressures. Proc. Physics Soc., London, 67B, 369-386 (1954).

5407 P. De11a Porta, Performance characteristics of barium getters at elevated working, temperatures of the valves. Vacuum $\underline{4}, 464-475$ (1954).

5408 P. Della Porta, Performance characteristics of barium getters. 18 references. Vacuum 4, 284-302 (1954).
5409 G. K. T. Conn \& H. N. Daglish, a thermionic ionization gage of high sensitivity employing a magnetic field. J. Sci. Insts. $31,412-415$ (1954).

5410 G. K. T. Conn \& H. N. Daglish, The influence of the ballast resistance on the performance of Penning vacuum gauges. J. Sci. Insts. $31,433-434$ (1.954).

5411 A. H. Beck \& G. King, A sensitive leak detector using magnetron ionization gauges. Vacuum 4, 147-158 (1954).

5412 G. K. T. Conn \& H. N. Daglish, The influence of electrode geometry on cold-cathode vacuum gauges. Vacuum $\underline{4}, 136-146$ (1954).

5413 N. A. Florescu, The ultimate vacuum obtainable in vapour pumps. 17 references. Vacuum 4 , 30-39 (1954).

5414 D. A. Hock1y \& C. S. Bul1, The ultimate vacua of two-stage rotary oil pumps. Vacuum 4, 40-47 (1954).

5415 S. Elonka, Gaskets. Power, p. 105-124 (March 1954).

5416 M. P. Garfunke1 \& A. Wexler, Measurement of high vacuum at low temperatures. Rev. Sci. Inst. 25, 170-172 (1954).

5417 C. Hayaski, on the rate of decomposition of diffusion pump oil. J. Phys. Soc., Japan, 9, 287-290 (1954).

5418 F. A. McMillan, Liquid manometers with high sensitivity and small time-lag. J. Sci. Inst. 31, 17-20 (1954).

5419 K. Phillips, Some experiments with a coldvacuum gauge. J. Sci. Inst. 31, 110 (1954).

5420 L. Riddiford \& R. F. Coe, The theory of high speed oil diffusion pumps. J. Sci. Insts. 31, 33-36 (1954).

5421 E. M. Robson, Some aspects of micro-moisture determination. Vacuum $\underline{4}, 60-66$ (1954).

5422 K. A. Savinskii, High vacuum equipment in Russia. 27 references. Vacuum 4, 326-340 (1954). (Translation from Zavodskaya Laboratoriya, No. 9 (1955).)

5423 R. S. Bradley, A thermistef McLeod gauge for a pressure range $1-10^{-7}$ m of mercury. J. Sci. Inst. 31, 129-130 (1954).

5424 R. Geller, Economical use of a leak detector spectrometer. In French. Commis. 1'Energy Atomique Report No. 256 (1954).

5425 H. Gruber, Remarks on a thermister Piranitype vacuum gage. Glas-und-Hochvakuum Tech. 2, 302-306 (1954). 
5426 A. M. Gurewitsch \& K. F. Westendorp, Ionic pump. Rev. Sci. Inst. 25, 389-390 (1954).

5427 R. Jaecke1, H. G. No1ler \& H. Kutscher, The physical processes in diffusion and ejector pumps. In German. Vakuum-Tech. 3, 1-15 (April 1954).

5428 P. A. Redhead \& L. R. McNarry, An ionization manometer and control unit for extremely low pressures. Canad. J. Phys. 32, 267274 (1954).

5429 A. Venema, The determination of pump speed. 11 references. Vacuum $4,272-283$ (1954).

5430 F. de Boer \& W. F. Niklas, Applications of a tracer to cathode-gettering and gasadsorption problems. Brit. J. App1. Phys. 5, 341-342 (1954).

5431 G. W. Hess, W. Eat on \& J. Lech, The knifeedge vacuum seal. Vacuum 4, 438-444 (1954).

5432 C. S. Martin \& J. H. Leck, Pumping speed fluctuations in the oil diffusion pump. Vacuum 4, 486-489 (1954).

5433 B. D. Yower \& D. J. Crawley, Sources, measurement and control of backstreaming in oil vapour vacuum pumps. Vacuum $\underline{4}, 415-437$ (1954).

5434 W. A. Rogers, R. S. Buritz \& D. Alpert, Diffusion coefficient, solubility and permeability for helium in glass. J. App1. Phys. 25, 868-875 (1954).

5435 L. J. Varnerin, Jr. \& D. White, U1timate vacuum in a vacuum-enclosed ionization gage. J. App1. Phys. 25, 1207-1208 (1954).

5436 M. Reichardt, Investigation of glass mercury diffusion pumps. In German. $\mathrm{Zt}$. angew. Phys. 6, 61-64, 104-108 (1954).

5437 Y. Takamura, A Pirani gauge combined with triode tube. In Japanese. Oyo Butsuri, $\underline{23}, 558-560(1954)$.

5438 D. I. Gaffee \& A. G. Monroe, Measurement of sma11 differential pressures at 1ow absolute pressures. Nature 174, 756 (1954).

5439 R. Geller, The leak problem in vacuum engineering. Construction of a leak detector mass spectrometer. In French. Commis. 1 'Energy Atomique Report No. 325 (1954).

5440 A. E. Cameron, A compact high-vacuum valve. Rev. Sci. Inst. 25, 1027-1028 (1954).

5441 P. E. Douglas, The vapour pressure of calcium. Proc. Phys. Soc., London 67, 783786 (1954).

5442 A. J. Martin, Metal seals in vacuum equipment. Atomic Weapons Res. Estab1. Report No. 0-40/54 (Aug. 1954).
5443 D. A. Lundberg, A differential leak detector for evacuated vesse1s. Electronic Eng. 26, $436-440$ (1954).

5444 L. Landecker \& J. Gray, Diffusion of gases through nicke1 and design of a convenient leak for hydrogen and deuterium. Rev. Sci. Inst. 25, 1151 (1954).

5445 C. W. Oatley, The experimental determination of the speed of a vacuum pump and of components of a vacuum system. Brit. J. App1. Phys. 5, 358-362 (1954).

5446 R. W. Decker, A11-glass valves for use in obtaining ultra high vacua. J. App1. Phys. 25, 1441-1442 (1954).

5447 E. Waldschmidt, Evolution of gas and permeability to gas of constructional metals for vacuum systems. Meta11, No. 19/20 (Oct. 1954). Translation, J. Standring, AEA Report No. IGRL-T/C 25 (1956).

5448 D. Alpert \& R. S. Buritz, U1tra-high vacuum II. Limiting factors on the attainment of very low pressures. J. App1. Phys. 25, 202209 (1954).

5449 E. Brannen \& H. I. S. Ferguson, A simple universal vacuum joint. Rev. Sci. Inst. 25, 836-837 (1954)

5450 P. F. Varadi, Some remarks on ion pumps. Vacuum 4, 66-67 (1954) (pub1ished 1956).

5451 R. H. Davis \& A. S. Divatia, Design and operation of Evapor-ion pumps. Rev. Sci. Inst. 25, 1193-1197 (1954).

5452 G. L. Fox, A large-diameter reciprocatingaction vacuum valve. Rev. Sci. Inst. 25 , 616 (1954)

5453 D. T. Hurd \& M. L. Corrin, A recording vacuum gauge. Rev. Sci. Inst. 25, 1126-1128 (1954).

5454 H. V. Neher \& A. R. Johnston, Techniques useful in evacuating and pressurizing metal chambers. Rev. Sci. Inst. 25, 517-518 (1954).

5455 R. G. Nester, A new type of absolute manometer. Rev. Sci. Inst. 25, 1136-1137 (1954).

5456 J. R. Pappenheimer, Differential conductance manometer. Rev. Sci. Inst. 25, 912-917 (1954).

5457 H. H. Pattee, Jr., A demountable ultra-high vacuum joint. Rev. Sci. Inst. 25, 1132-1133 (1954).

5458 J. H. Reynolds \& J. Lipson, A multicircuit control for ultra-high vacuum gauges. Rev. Sci. Inst. 25, 1029-1031 (1954). 
5459 R. J. Richards, A high-vacuum seal-off valve. Rev. Sci. Inst. 25, 520-521 (1954).

5460 J. A. Stark \& A. Langsdorf, Jr., A high vacuum plug valve. Rev. Sci. Inst. 25, 188 (1954).

5461 F. S, Stein, A three-way vacuum valve. Rev. Sci. Inst. 25, 515-516 (1954).

5462 M. K. Wilson, Elimination of adsorbed water in vacuum systems. Rev. Sci. Inst. 25, 1130 (1954).

5463 D. Alpert, U1tra-high vacuum technology. Vacuum Symp. Trans. (1954). Committee Vac. Tech., Boston, Mass., 69-75 (1955).

5464 C. H. Bachman \& P. A. Silberg, Gas flow in capillaries of non-circular cross section. Vacuum Symp. Trans. (1954). Committee Vac. Tech., Boston, Mass., 63-64 (1955).

5465 R. M. Boehme, A vane type flow meter. Vacuum Symp. Trans. (1954). Committee Vac. Tech., Boston, Mass., 7-10 (1955).

5466 W. E. Briggs, The molecular vacuum gauge. Vacuum Symp. Trans. (1954). Committee Vac. Tech., Boston, Mass., 3-6 (1955).

5467 A. S. Divatia \& R. H. Davis, Construction and performance of Evapor-ion pumps. Vacuum Symp. Trans. (1954). Committee Vac. Tech., Boston, Mass., 40-45 (1955).

5468 C. Felheimer \& A. A. Litwak, Automatic valving system for vacuum apparatus. Vacuum Symp. Trans. (1954). Committee Vac. Tech., Boston, Mass., 35-39 (1955).

5469 W. C. Frye, Gas ballast for mechanical high vacuum pumps. Vacuum Symp. Trans. (1954). Committee Vac. Tech., Boston, Mass., 17-18 (1955).

5470 G. P. Gerow, Pumping systems for the $1 \mathrm{ml}$ cron to 1 millimeter range. Vacuum Trans. (1954). Committee Vac. Tech. Boston, Mass., 23-26 (1955).

5471 J. J. Kinse11a, The dependence of ionization gauge sensitivity on electrode geometry. Vacuum Symp. Trans. (1954). Committee Vac. Tech., Boston, Mass., 65-68 (1955).

5472 R. B. Lawrance, A simplified method of calculating pressure drop in vacuum piping. Vacuum Symp. Trans. (1954). Committee Vac. Tech., Boston, Mass., 55-62 (1955).

5473 F. J. Norton, Permeation problems in high vacuum. 14 references. Vacuum Symp. Trans. (1954). Committee Vac. Tech., Boston, Mass., 47-51 (1955).

5474 W. B. Nottingham, Design and properties of the modified Bayard-Alpert gauge. Vacuum Symp. Trans. (1954). Committee Vac. Tech., Boston, Mass., 76-80 (1955).
5475 P. A. Silberg \& C. H. Bachman, Some studies of the diffusion of hydrogen through palladium. 8 references. Vacuum Symp. Trans. (1954). Committee Vac. Tech., Boston, Mass. $(52-54)$.

5476 A. L. Smith \& J. C. Saylor, The current status of silicone diffusion pump fluids. Vacuum Symp. Trans. (1954). Committee Vac. Tech., Boston, Mass., 31-34 (1955).

5477 G. A. Sofer, Some observations in the operation of vacuum diffusion pumps. Vacuum Symp. Trans. (1954). Committee Vac. Tech., Boston, Mass., 27-30 (1955).

5478 G. K. T. Conn \& H. N. Daglish, A simple thermionic vacuum gauge. J. Sci. Inst. 31 , 95-96 (1954).

5479 M. F. Behar, Pressure and vacuum. Chapter in Handbook of measurement and contro1, Part II, Instruments and automation, 27, 57-73 (Dec., 1954).

5480 E. W. Flosdorf, The Mcleod gage. Inst. \& Autom. 27, 1795-1796 (1954).

5481 R. T. Eckenrode \& H. A. Kirshner, Measurement of pressure transients. 112 references. Rev. Sci. Inst. 25, 33-40 (1954).

5482 J. W. Hiby \& M. Pah1, Compensated ionization gage. In German. Zt. Naturforsch. 9a, 906907 (1954).

5483 Y. Sugiura, Experimental studies on the force. exerted on a disc placed in a flow of rarified gas. J. Phys. Soc., Japan 9, 244-248 (1954).

5484 S. Murata, Relation between gas pressure and ion current in vacuumfures In Japanese. J. Inst. E1ect. Comm. Eng., Japan 37, 865-870 (1954).

5485 R. Haefer, The current-voltage characteristics of a self-sustained gaseous discharge in a transverse magnetic field. In German. Acta Physica Austriaca 8, 213-224 (1954).

5486 K. D. Mielenz, Pressure measurement with a Pirani gage. In German. $z^{t}$. angew. Phys. 6 , 101-104 (1954).

5487 E. Huebner, Measurement of low variable pressures. In German. Forsch. Gebiete Ingenieur wesens $20,20-31$ (1954).

5488 L. F. G. Simmons, Sensitive air manometer. J. Sci. Inst. 31, 195-197 (1954).

5489 N. B. Hannay, A mass spectograph for the analysis of solids. Rev. Sci. Inst. 25, 644648 (1954).

5490 E. A. Flauraud, A. H. Mears, F. A. Crowley \& A. P. Crary, Investigation of microbarometric oscillations in eastern Massachusetts. Air Force Cambr. Research Center Technical Report 54-11, Geophysical Research Paper No. 27, 62 p. (1954). 
5491 R. Yamamoto, Microbarographic oscillations produced by the explosions of hydrogenbombs. Univ. Meteoro. Research Inst.Kyoto, Meteoro. Notes Ser. 2, No. 1, 14 p. Also, Bu11. Inst. Chem. Research, p. 120-123 (1954). A1so, Weather, 10, 321-325 (1955).

5501. C. N. W. Litting, A Pirani gauge circuit. J. Sci. Inst. 32, 91-92 (1955).

5502 J. Morrison \& R. B. Zetterstrom, Barium getters in carbon monoxide. J. App1. Phys. 26, 437-442 (1955).

5503 B. J. Todd, Outgassing of glass. J. App1. Physics 26, 1138-1243 (1955).

5504 E. Bouwmeester \& N. Warmo1tz, A simple and reliable ionization manometer. Philips Tech. Rev. 17, 121-125 (1955).

5505 G. Dumas, Study of gyromagnetic resonance in a Penning gauge. In French. Revue Gén. E1ect. 64, 331-349 (1955).

5506 E. Brown \& J. H. Leck, Desorption of gas in the cold-cathode ionization gauge. Brit. J. App1. Physics 6, 161-164 (1955).

5507 T. B. Kent, A hydrogen Pirani leak detector using a charcoal trap. J. Sci. Insts. 32, 132-134 (1955).

5508 R. F. Coe \& L. Riddiford, The final vacua of oil diffusion pumps. J. Sci. Insts. 32, 207-213 (1955).

5509 R. Thees, Roots pumps, design and performance. Vacuum 5, 25-34 (1955).

5510 J. G. S. Biram, Some aspects of handling mercury. 57 references. Vacuum 5, 77-92 (1955).

5511 A. G. Edwards, Vacuum research and the mass spectrometer. 46 references. Vacuum $\underline{5}$, 93-108 (1955).

5512 H. G. Noller, The physics of modern vapour pumps with particular reference to diffusion pumps. 26 references. Vacuum $\underline{5}, 59-$ 76 (1955).

5513 B. D. Power \& R. A. Kenna, Vapour pumping characteristics of gas ballast pumps. Vacuum 5, 35-58 (1955).

5514 J. A. Becker, U1tra high vacua. Be11 Lab. Record 33, 1-5 (1955).

5515 M. Reichardt, Investigation of glass mercury diffusion pumps. III. In German. Zt. angew. Phys. 7, 297-301 (1955).

5516 R. Thees \& H. Treupe1, Mechanical vacuum pumps. In German. Elektrotech. Zt. 7B, 321-324 (1955).
5517 L. J. Varnerin \& J. H. Carmichael, Ionic pumping mechanism of helium in an ionisation gauge. J. App1. Phys. 26, 782-783 (1955).

5518 F. M. Ernsberger \& H. W. Pitman, New absoluto manometer for vapour pressures in the micron range. Rev. Sci. Insts. 26, 584-589 (1955).

5519 A. Johannin-Gilles \& P. Johannin, Apparatus for measuring vapour pressure. In French. J. Phys. Radium 16, 236-237 (1955).

5520 Y. Lortie, The uses of thermistors as vacuum gauges. In French. J. Phys. Radium 16, 317320 (1955).

5521 L. R. Taylor, A tilting micromanometer with continuous sensitivity control. J. Sci. Inst. $32,173-177$ (1955).

5522 R. Geller, Sensitivity of a leak detector mass spectrometer. In French. Le Vide 10 , 119-123 (1955).

5523 0. M. Ballentine, Procedure for determining vapour pressures of materials of low volatility. Wright Air Dev. Center Technical Report No. 54-418 (1955).

5524 D. G. Bills \& F. G. Allen, U1tra-high vacuum valve. Rev. Sci. Inst. 26, 654-656 (1955).

5525 E. C. Giaimo, Jr., Ring-type teflon gasket. Rev. Sci. Inst. 26, 520 (1955).

5526 E. R. Harrison \& L. C. W. Hobbis, Nicke1 diffusion leak for hydrogen. Rev. Sci. Inst. 26, 305-306 (1955).

5527 R. Hoerbe \& 0 . Knacke, Vapour pressure curves for 140 materials. In German. Zt. Ergbergbau Meta11huttenw. 8, 556-561 (1955).

5528 0. Knapp, Chemical composition of special glasses for high-vacuum techniques. In German. Silikattech. 6, 99-104 (1955).

5529 R. A. Lowry, J. E. Osher \& G. H. Miller, A pressure regulator for a low-pressure continuous-flow ionization chamber. Atomic Energy Com. Report No. 15C-599 (1955).

5530 F. L. Reynolds, The use of indium in high vacuum equipment. A tomic Energy Com. Report No. UCRL 2989, 3 p. (May 1955).

5531 E. Thomas, Lazy-tong 1inkage to obtain rectilinear movement in an evacuated chamber. Bu11. Classe Sci. 839-841 (1955).

5532 D. W. Juenker, M. Swaay \& C. E. Birchenal1, On the use of palladium diffusion membranes for the purification of hydrogen. Rev. Sci. Inst. 26, 888 (1955).

5533 D. Alpert, Experiments at very low pressures. Science 122, 729-733 (1955). 
5534 A. M. 0. Smith \& J. S. Murphy, Micromanometer for measuring boundary layer profiles. J. Sci. Inst. 26, 775-781 (1955).

5535 V. L. Stout \& M. D. Gibbons, Gettering of gas by titanium. J. App1. Phys. 26, 14881492 (1955).

5536 L. E. Levina, Modern methods of leak detection. In Russian. Uspekhi Fizicheskikh Nauk 55, 101-110 (1955).

5537 P. J. van Heerden, Metal gaskets for demountable vacuum systems. Rev. Sci. Inst. $26,1130-1131$ (1955).

5538 J. Horseling, A high vacuum tap with short outgassing time. Philips Tech. Rev. 17, 184-186 (1955).

5539 J. H. Leck, Modern developments in the techniques of vacuum pressure measurements. Proc. Inst. Electronics 38-2, 25-34 (1955).

5540 W. G. Brombacher \& T. W. Lashof, Bibliography and index on dynamic pressure measurement. Nat. Bur. Stds. Circ.558, 124 p. (1955).

5541 C. R. Meissner, Liquid nitrogen cold traps. Rev. Sci. Inst. 26, 305 (1955).

5542 I. Alexeff \& E. C. Peterson, Evapor-ion pump performance with noble gases. Vac. Symp. Trans. (1955). Committee Vac. Tech. Inc., Boston, Mass. 87-90 (1956).

5543 G. Hees, W. Eaton \& J. Lech, The knife edge vacuum sea1. Vac. Symp. Trans. (1955). Committee Vac. Tech. Inc., Boston, Mass. 75-79 (1956).

5544 P. B. Kennedy \& H. R. Smith, A simple twostage mechanical refrigeration system for cold traps and boffles. Vac. Symp. Trans. (1955). Committee Vac. Tech. Inc, Boston, Mass., 80-82 (1956).

5545 H. Landsberg, E. E. Escher, \& S. A. Dawkins, Continuous analysis of gases in a high vacuum furnace with a monitoring mass spectrometer. Vac. Symp. Trans. (1955). Committee Vac. Tech. Inc., Boston, Mass. 4550 (1956).

5546 J. L. Peters, Development and performance of a new ion gauge tube and control circuit. Vac. Symp. Trans. (1955). Committee Vac. Tech. Inc., Boston, Mass, 71-73 (1956).

$5 ๖ 47$ F. L. Reynolds, A11-metal vacuum valve using an indium seat. Vac. Symp. Trans. (1955). Committee Vac. Tech. Inc.,Boston, Mass., 74 (1956).

5548 D. J. Santeler, A graphical solution for the analysis of vacuum systems performance. Vac. Symp. Trans. (1955). Committee Vac. Tech. Inc. Boston, Mass., 31-41 (1956).
5549 H. R. Smith, The technology of large mercury pumped vacuum systems. Vac. Symp. Trans. (1955). Committee Vac. Tech. Inc.,Boston, Mass. p. 22-30 (1956).

5550 J. C. Swartz, Evapor-ion pump characteristics. Vac. Symp. Trans. (1955). Committee Vac. Tech. Inc., Boston, Mass., 83-86 (1956).

5551 R. Haefer, Methods of measurement of low gas pressures by means of a self-sustaining gaseous discharge in a transverse magnetic field. Acta Phys. Austriaca 9, 200-215 (1955).

5552 A. G. Edwards, Some properties of a simple omegatron-type mass spectrometer. Brit. J. App1. Phys. 6, 44-48 (1955).

5553 R. Gomer, Field emission microscopy and some applications to catalysis and chemisorption. Advances in Catalysis VII, Academic Press, New York, p. 93-134 (1955).

5554 J. A. Becker, Adsorption on meta1 surfaces and its bearing on catalysis. Advances in Catalysis VII, Academic Press, New York, p. 135-211 (1955).

5555 N. D. Morgulis, Ionization method of obtaining very high vacuum. J. Tech. Phys. USSR 25, 1667-1670 (1955).

5556 D. G. Bills, F. G. Allen \& N. P. Carleton, Measurement of the pumping speed of an ionization gauge. (Abstract). Phys. Rev. 99, 1662 (1955).

5557 J. A. Becker \& R. G. Brandes, The adsorption of oxygen on tungsten as revealed in the field emission electron microscope. J. Chem. Phys. 23, 1323-1330 (1955).

5558 L. E. Bollinger, $3 \mathrm{C} 24$ ionization gage. Inst. \& Autom. 28, 1507-1509 (1955).

5559 B. G. Childs \& J. Penfeld, Automatic vacuum pump control circuit. Rev. Sci. Inst. 26, 235-236 (1955).

5560 H. Kiefer \& B. Ziegler, Combined quartz-fiber and Knudsen gage for measuring vapor pressure. In German. Zt. angew. Phys. I, 48-50 (1955).

5561 M.Varićak \& B. Vošicki, Oscillographic measurement of the Penning-gauge characteristics. J. Sci. Inst. 32, 346-348 (1955).

5562 J. J. Opste1ten \& N. Warmoltz, A double-sided micromanometer. Appl. Sci. Res, 4B, 329-336 (1955).

5563 B. L. Harris, Adsorption. 352 references. Ind. Eng. Chem. 47, 508-517 (1955). 
5564 R. W. Raible \& M. K. Testermann, Ion-gage supp1y protects tubes. Electronics $28,210-$ 218 (Feb. 1955).

5565 H. Seifert, R. Buh1 \& K. F. Seifert, Fine structure in adsorption processes on quartz surfaces. Ko11oid Zt. 141, 146-159 (1955).

5566 D. J. Wright, Hysteresis of the angle of contact of mercury against steel. Proc. Phys. Soc., London, 68B 297-303 (1955).

5567 H. G. Noeller, The physical processes occuring in diffusion and vapor-jet pumps. I. Properties of the vapor jet stability of the forevacuum. II. Mixing of air and vapor, and the pumping speed. In German. $\mathrm{Zt}$. angew. Phys. 7, 218-229 (1955).

5568 L. T. Minchen, New ideas in manometer design. Gas J. 283, 389 (1955).

5569 D. Patterson \& R. C. Seymour, Automatic pressure recorder for study of gas phase kinetics. J. Sci. Inst. 32, 50-51 (1955).

5570 E. Rideal \& A. J. Robertson, Sensitive manometer for rapid chemical changes. J. Sci. Inst. $32,349-350$ (1955).

5571 A. M. Thackara, Fundamentals of pressure control. Inst. \& Automation 28, 2094-2097 (1955).

5572 K. Ziock, Development of a vacuum gage in the range 0.1-10 mm. In German. Forschungsber. Wirtsch-u-Verkehrsministeriums NordrheinWestfallen, No. 189, 24-28 (1955).

5573 H. S. Katzenstein \& S. S. Friedland, New timeof-flight-mass spectrometer. Rev. Sci. Inst. 26, 324-327 (1955).

5574 E. Weissmann, Measurement of gas-kinetic cross-section by radiometric forces. VakuumTech. $\underline{4}, 152-155$ (1955).

5575 G. H. Lee \& L. M. Van der Py1, A bibliography on diaphragms and aneroids. 426 abstracts. Am. Soc. Mech. Eng. Paper No. 55-A-180 (1955). 60-WA-122 (1960).

5601 J. H. Leck \& C. S. Martin, A Pirani gauge for operation up to a pressure of $10 \mathrm{~mm}$ of mercury. J. Sci. Inst. 33, 181-183 (1956).

5602 D. J. Santeler \& T. W. Moller, Leak detection I. Fluid flow conversion in leaks and capillaries. General Engineering Lab., General Flectric Co. Report No. 56-GL-261, 16 p. (0ct. 1956).

5603 B. J. Todd, Equilibrium between glass and water vapor at bake out temperatures. J. App1. Physics 27, 1209-1210 (1956).
5604 J. H. Leck \& A. Riddoch, Observations on the characteristics of the cold cathode ionization gauge. Brit. J. App1. Phys. 7, 153-155 (1956).

5605 P. F. Varadi \& L. G. Sebestyen, A simple vacuum detector using a radio-frequency mass spectrometer. J. Sci. Insts. 33, 392-394 (1956).

5606 R. M. Glaister, A magnetically operated vacuum valve. J. Sci. Inst. 33, 34-35 (1956).

5607 R. G. Nester, High vacuum gas valve. Rev. Sci. Inst. 27, 874-875 (1956).

5608 R. K. Smither, Controlled capillary gas leak. Rev. Sci. Inst. 27, 964-965 (1956).

5609 R. P. Henry, Absolute pressure determination with the aid of an ionization gauge. In French. Le Vide 11, 54-63 (1956).

5610 A. Beck, The stability of thermistors. J. Sci. Inst. 33, 16-18 (1956).

5611 J. Delcher, R. Geller, G. Mongodin \& F. Prevot, Diffusion pump with freon-12. In French. Le Vide 11, 78-80 (1956).

5612 D. J. Harris \& P. 0. Hawkins, Use of Krypton 85 in measuring gas clean-up rates. Nature 177, 285-286 (1956).

5613 P. Lott, Simplified method for McLeod gauge design and calibration. Anal. Chem. 28, 276-277 (1956).

5614 S. Lynn, W. H. Corcoran \& B. H. Sage, Micromanometer of high sensitivity. Rev. Sci. Inst. 27, 368-369 (1956).

5615 P. G. Morgan, The Pirani gauge, Elect. J. 156, 1999-2000 (1956).

5616 J. J. Opste1ten, N. Warmo1tz \& J. J. Z. van Zelst, A direct-reading double sided micromanometer. App1. Sci. Res. 6B, 129-136 (1956).

5617 K. M. Sancier \& W. Richeson, Simple sensitive electrical pressure gage. Rev. Sci. Inst. 27, 134-136 (1956).

$5618 \mathrm{H}$. Schlitt, A thermoelectric vacuum gauge. In German. Zt. angew. Phys. 8, 216-217 (1956).

5619 M. Varicak, Thermistors for the measurement of low pressures. In French. Compte Rend. $\underline{243}, 893-895$ (1956).

5620 J. P. Verkamp \& S. L. Williams, Testing nuclear-plant leak tightness. Nucleonics 14, 54-57 (June 1956).

5621 H. A. Kyllie, A McLeod gage for measuring a wide range of pressures. J. Sci. Insts. 33, 317 (1956). 
5622 H. A. Wy11ie, A gas introducer for a vacuum system. J. Sci. Inst. 33, 360-361 (1956).

5623 J. A insworth \& H. E. LaGow, Vacuum gauge chamber response time. Rev. Sci. Inst. 27, 653-654 (1956).

5624 D. T. Scag, U1tra-high vacuum with an a11metal system. Conference on controlled thermonuclear reactions, Gatlinburg, Tenn., p. 630-635 (1956). (TID-7520 Pt. 2).

5625 W. Espe, Copper as a high vacuum material. In German. Nachrichtentech. 6, 355-364 (1956).

5626 A. W. Knudsen, Fast-closing vacuum valve. Rev. Sci. Inst. 27, 148-150 (1956).

5627 M. Varićak, Penning gauge as leak detector. Rev. Sci. Inst. 27, 655 (1956).

5628 T. P. Vog1 \& H. D. Evans, Electromagnetica11y operated ultra-high vacuum valve. Rev. Sci. Inst. 27, 657 (1956).

5629 0. Amse1 \& G. Wittwer, A nul1 method for the measurement of low vapor pressures. In German. Zt. angew. Phys. 8, 20-24 (1956).

5630 R. L. Be11, The omegatron as a leak detector. J. Sci. Inst. 33, 269-272 (1956).

5631 W. Espe, Methods and technique of degassing metals. In German. Vakuum-Tech. 5, 39-53 (May 1956); 69-82 (June 1956).

5632 J. T. Law \& E. E. Francois, Adsorption of gases on a silicon surface. J. Phys. Chem. $60,353-358$ (1956).

5633 A. S. Newton, Method of degassing 1iquids. Ana1. Chem. 28, 1214-1215 (1956).

5634 R. N. Bloomer, Absorption of oxygen and carbon monoxide by barium getters. Nature 178, 1000-1001 (1956).

5635 W. Dong, Vacuum t'low of gases through channels with circular, annular and rectangular cross sections. Atomic Energy Com. Report No. UCRL 3353 (April 1956).

5636 C. Jech, Clean-up of radioactive gases used for surface studies. Nature 178, 1343-1344 (1956).

5637 F. Kirchner \& H. Kirchner, On the measurement of very low gas and vapour pressures. In German. Zt. angew. Phys. 8, 478-481 (1956).

5638 G. Urry \& W. H. Urry, Automatic Toepler pump of improved design. Rev. Sci. Inst. 27, 819-820 (1956).

5639 H. Moesta, The behavior of the gas discharge in the Penning vacuum gauge. In German. Zt. angew. Phys. 8, 598-603 (1956).
5640 J. H. Beynon \& G. R. Nicholson,A radioactive ionization gauge and its application to the measurement of latent heat of vaporization. J. Sci. Inst. 33, 376-380 (1956).

5641 P. Hariharan \& M. S. Bhalla, An improved ionization gauge control circuit. J. Sci. Inst. 33, 488-491 (1956).

5642 H. Black, A sma11 mercury cut-off withstanding large pressure differences. Nature 178, 1307-1308 (1956).

5643 G. Milazzo, The measurement of sma11 vapour pressures. In German. 28 references. Chem. Ing. Tech. 28, 646-653 (1956).

5644 R. Millican, Low flow variable leak. Atomic Energy Com. Report No. KY-166, 13 p. (1956).

5645 C. M. Van Atta, Theory and performance characteristics of a positive displacement rotary compressor as a mechanical booster vacuum pump. Vacuum Symp. Trans. (1956). Committee Vac. Tech., Inc., Boston, Mass., 62-70 (1957).

5646 J. M. Benson, Thermopile vacuum gauges having transient temperature compensation and direct reading over extended ranges. Vacuum Symp. Trans. (1956). Committee Vac. Tech., Inc., Boston, Mass., 87-90 (1957).

5647 C. G. Blatch1ey, Contro1 of ejector type vaccuum pumps. Vacuum Symp. Trans. (1956). Committee Vac. Tech., Inc., Boston, Mass., 45-51 (1957).

5648 D. E. Charpentier, A simplified mass spectrometer type helium leak detector. Vacuum Symp. Trans. (1956). Committee Vac. Tech., Inc., Boston, Mass., 114-118 (1957).

5649 N. E. Cooke, An inherent error in the Knudsen effusion manometer and a method of correction. Vacuum Symp. Trans. (1956). Committee Vac. Tech., Inc., Boston, Mass., 82-86 (1957).

5650 B. B. Dayton, Gas flow patterns at entrance and exit of cylindrical tubes. Vacuum Symp. Trans. (1956). Committee Vac. Tech. Inc., Boston, Mass., 5-11 (1957).

5651 A. J. Gale, Cold sealed getter/ion pumped supervo1tage X-ray tubes. Vacuum Symp. Trans. (1956). Committee Vac. Tech. Inc., Boston, Mass., 12-14 (1957).

5652 R. W. Griesse1, Applications of the mass spectrometer to tube development. Vacuum Symp. Trans. (1956). Committee Vac. Tech., Inc., Boston, Mass., 101-106 (1957).

5653 E. A. Gulbransen \& K. F. Andrews, Electron optical studies of oxidation processes occurring in high vacuum. Vacuum Symp. Trans. (1956). Committee Vac. Tech., Inc., Boston, Mass., 190-201 (1957). 
5654 K. C. D. Hickman \& J. J. Kinse11a, A precondictioned vapor vacuum pump. Vacuum Symp. Trans. (1956). Committee Vac. Tech., Inc., Boston, Mass., 52-56 (1957).

5655 J. A. LeBlanc, Vacuum gauge calibration system. Vacuum Symp. Trans. (1956). Committee Vac. Tech., Inc., Boston, Mass., 78-81(1957).

5656 C. R. Meissner, A high vacuum laboratory for vapor deposition of conductors and dielectrics. Vacuum Symp. Trans. (1956). Committee Vac. Tech., Inc., Boston, Mass., 15-23 (1957).

5657 R. E. Moody, Versatile RF type leak detector. Vacuum Symp. Trans. (1956). Committee Vac. Tech., Inc., Boston, Mass., 119-123 (1957).

5658 A. Nerken, Experiments on flow of gases through leaks. Vacuum Symp. Trans. (1956). Committee Vac. Tech.,Inc., Boston, Mass., 1-4 (1957).

5659 J. Peters \& F. Raible, A new helium mass spectrometer leak detector. Vacuum Symp. Trans. (1956). Committee Vac. Tech., Inc., Boston, Mass., 107-109 (1957).

5660 J.A. Roberts, Precision leaks for standardizing leak detection equipment. Vacuum Symp. Trans. (1956). Committee Vac. Tech., Inc., Boston, Mass., 124-126 (1957).

5661 C. E. Rufer, The measurement of pumping speeds. Vacuum Symp. Trans. (1956). Committee Vac. Tech., Inc., Boston, Mass., 74-77 (1957).

5662 D. J. Santeler \& T. W. Moller, Fluid flow conversion in leaks and capillaries. Vacuum Symp. Trans. (1956). Committee Vac. Tech., Inc., Boston, Mass., 29-36 (1957).

5663 H. J. Schwarz, Acoustical vacuum gauge. Vacuum Symp. Trans. (1956). Committee Vac. Tech., Inc., Boston, Mass., 37-38 (1957).

5664 R. H. Vacca, Recent advances in the Alphatron vacuum gauge. Vacuum Symp. Trans. (1956). Committee Vac. Tech., Inc., Boston, Mass., 93-100 (1957).

5665 J. R. Young, Electrical clean-up of gases in an ionization gauge. J. App1. Phys. 27, 926-928 (1956).

5666 N. Jensen, Vapour pressure of plastic materials. J. App1. Phys. 27, 1460-1462 (1956).

5667 R. Haefer \& 0. Winkler, Factors which determine the final vacuum in vacuum systems equipped with oil diffusion pumps. VakuumTech. 7, 149-155 (1956).

5668 J. H. Reynolds, High sensitivity mass spectrometer for noble gas analysis. Rev. Sci. Inst. 27, 928-934 (1956).
5669 K. J. Higatsberger \& W. W. Erbe, Improved metal to metal vacuum seals. Rev. Sci. Inst. 27, 110-11 (1956).

5670 G. Ehrlich, The mechanism of chemisorption on metals. J. Phys. Chem. Solids 1, 3-13 (1956).

5671 G. Ehrlich, The interaction of nitrogen with a tungsten surface. J. Phys. Chem. 60, 13881400 (1956).

5672 R. E. Soh1ier \& H. E. Farnsworth, Low-energy electron diffraction studies of cleaned and gas-covered germanium (100) surfaces. Semiconductor Surface Physics, R. H. Kingston, Editor, Univ. Penna. Press, 3-22 (1956).

5673 H. D. Hagstrum, Effect of monolayer adsorption on the ejection of electrons from metals by ions. Phys. Rev. 104, 1516-1527 (1956).

5674 J. M. Houston, New ultra-high-vacuum ionization gauge. (Abstract). Bull. Am. Phys. Soc., (II) 1 , 301 (1956).

5675 J. H. de Boer, Adsorption phenomena. 407 references. Advances in catalysis, VIII Academic Press, New York, 18-161 (1956).

5676 V. R. Deitz, Bibliography of solid adsorbents. 13,763 references. Nat. Bur. Stds. Circ. 566,1528 p. (1956).

5677 G. Milazzo, On a possible source of error in measuring pressure with a capacity micromanometer. Zt. Elektrochemie 60, 185-188 (1956).

5678 W. B. Nottingham, Thermionic emission. Handbuch der Physik, Springer-Verlag, 21, 1-175 (1956). A1so Tech Report 321, Mass. Inst. Tech. Research Lab. of Electronics, $178 \mathrm{p}$. (1956).

5679 F. B. Jennings, Theories on Bourdon tubes. Trans. Am. Soc. Mech. Eng. 78, 55-64 (1956).

5680 J. B. Johnson, Convection type manometer. Rev. Sci. Inst. 27, 303-305 (1956).

5681 P. Tritsmans, Gas analysis with the mass spectrometer. In Dutch. Techn.-Wetensch. Tijdschrift. 25, 183-186 (1956).

5682 A. von Weiss, Vibration-free mountings and vibration-proof construction of instruments. In German. Ver. Deut. Ing. Zt. 98, 205-208 (1956).

5683 W. Schuetze \& F. Bernhard, A new method of measuring very small ion currents in high vacuum. In German. $\mathrm{Zt}$. Phys. 145, 44-47 (1956). 
5684 E. W. Mueller, Field emission microscopy. 58 references. Physical methods in chemical analysis. W. G. Ber1, Editor, Academic Press, vo1. 3, 135-182 (1956).

5701 J. Drowart, P. Goldfinger \& R. Van Steenwinkel, A new demountable ultra-high vacuum joint. J. Sci. Insts. 34, 248-249 (1957)

5702 G. Burrows, Some consequences of the behavior of mobile molecules. Vacuum $7-8,3-18$ (1957) (pub1. 1959).

5703 N. W. Robinson, Some vacuum problems in the valve industry. 21 references. Vacuum 6 , 21-40 (1957) (pub1. 1959).

5704 L. Páty, High vacuum gas-leak valves. 18 references. Vacuum 7-8, 80-86 (1957) (pub1. 1959).

5705 G. K. T. Conn \& H. N. Dag1ish, A three-electrode form of cold cathode ionisation gage. Vacuum 7-8, 72-79 (1957) (pub1. 1959).

5706 J. Amoignon, J. De1cher \& R. Ge1ler, Microleak valves. In French. Le Vide 12, 176183 (1957).

5707 R. N. Bloomer, Barium getters and oxygen. Brit. J. App1. Phys. 8, 40-43 (1957).

5708 R. N. Bloomer, The oxidation of evaporated barium films (getters). Brit. J. App1. Phys. 8, 321-329 (1957).

5709 R. N. Bloomer, Barium getters and carbon monoxide. Brit. J Appl. Phys. 8, 352-355 (1957).

5710 R. W. Cloud, L. Beckman \& J. G. Trump, Barium absorption pumps for high-vacuum systems. Rev. Sci. Inst. 28, 889-892 (1957).

5711 A. R. Hamilton, Extended range thermal conductivity vacuum gage. Rev. Sci. Inst. 28 , 693-695 (1957).

5712 W. J. Lange \& D. Alpert, Step-type demountable metal vacuum seal. Rev. Sci. Inst. 28 , 726 (1957).

5713 J. H. Leck \& C. S. Martin, Feedback contro1led heat conductivity gauge for measuring pressure in vacuum systems. Rev. Sci. Inst. 28, 119-121 (1957).

5714 J. A. McMillan \& Tomas Buch, Wide-range thermal convection manometer. Rev. Sci. Inst. 28, 881-882 (1957).

5715 R. G. Noster, New device for measuring low gas pressures. Rev. Sci. Inst. 28, 577 (1957).

5716 C. J. Penther, Vactroller-A laboratory vacuum controller. Rev. Sci. Inst. 28, 460463 (1957).
5717 L. Pátý \& P. Schürer, New u1tra-high vacuum valve. Rev. Sci. Inst. 28, 654-655 (1957).

5718 G. J. Schulz \& A. V. Phelps, Ionization gauges for measuring pressures up to the millimeter range. Rev. Sci. Inst. 28, 1051-1054 (1957).

5719 A. H. Spees, C. A. Reynolds, A. Boxer \& G. Pearson, Vacuum gasket at low temperatures. Rev. Sci. Inst. 28, 1090 (1957).

5720 L. H. Varnerin \& J. H. Carmichae1, Trapping of helium ions and re-emission of trapped atoms from molybdenum. J. App1. Phys. 28, 913-919 (1957).

5721 J. Yarwood, Ultra-high vacua. 25 references. J. Sci. Inst. 34, 297-304 (1957).

5722 R. W. Crompton \& M. T. Elford, A precision capsule-type pressure gauge for the range 0-20 mm of mercury. J. Sci. Inst. 34, 405407 (1957).

5723 L. D. Ha11, Rhenium ion gauge filament. Rev. Sci. Inst. 28, 653-654 (1957).

5724 H. Ishii \& K. Nakayama, High vacuum standards. I. The design and construction of a large standard McLeod gage. J. Japanese Vacuum Soc. 7, 113-120 (1957).

5725 H. Ishii \& K. Nakayama, High vacuum standards. II. Factors influencing the calibration of sub-standard ionization gauges. J. Japanese Vacuum Soc. 7, 176-188 (1957).

5726 M. W.Mallett \& K. M. Albrecht, Low-pressure solubility and diffusion of hydrogen in zirconium. J. Elect. Chem. Soc. 104, 142-146 (1957).

5727 H. Okamoto, On the abnormal outgassing in an ionization gauge. J. Japanese Vacuum Soc. 7, 71-89 (1957).

5728 J. S. Wagener \& P. T. Marth, Analys is of gases at very low pressures by using the omegatron spectrometer. J. Appl. Phys. 28, 1027-1030 (1957).

5729 G. J. Schulz, Characteristics of the BayardAlpert ionization gauge at pressures above $10^{-5} \mathrm{~mm} \mathrm{Hg}$. J. App1. Phys. 28, 1149-1152 (1957).

5730 P. E. Seiden, Wide range thermistor gauge. Rev. Sci. Inst. 28, 657-658 (1957).

5731 S. S. Stivala \& V. L. Denniger, Epoxy resin as sealant for high vacuum systems. Ind. Eng. Chem. 49, 1106 (1957).

5732 Y. Tuzi \& H. Okamoto, The adsorption of water vapour on glass surfaces in vacuum. $\mathrm{J}$. Japanese Vacuum Soc. 7, 216-230 (1957). 
5733 H. A. Adam, S. Kaufman \& B. S. Liley, Indium seals for dismountable vacuum systems. J. Sci. Inst. 34, 123-124 (1957).

5734 A. E. Barrington \& F. T. Turner, A contro1lable source of low-pressure hydrogen. J. Sci. Inst. 34, 286-287 (1957).

5735 R. N. B1oomer, Oxidation of barium: a confirmation of Mott's theory of oxidation. Nature 179, 493 (1957).

5736 C. D'Amico \& H. D. Hagstrum, Improvements in the use of the porcelain rod gas leak. Rev. Sci. Inst. 28, 60 (1957).

5737 V. A. Heathcote \& W. E. Read, A demountable seal for high vacuum work. J. Sci. Inst. 34, 247 (1957).

5738 S. Kobayashi \& K. Yada, A standard leak utilising gas permeation. J. Japanese Vacuum Soc. 7, 189-196 (1957).

5739 S. Toby \& K. 0. Kutschke, A1loy-filled cutoff for high temperatures. Rev. Sci. Inst. 28, 470-471 (1957).

5740 F. J. Norton, Permeation of gases through solids. J. App1. Phys. 28, 34-39 (1957).

5741 N. W. Robinson, Bakeable high vacuum sea1s. J. Sci. Inst. 34, 121 (1957).

5742 M. Sakisaka, Y. Oyama \& T. Furushima, Spectral analysis-type leak detector. J. Japanese Vacuum Soc. $7,121-130$ (1957).

5743 B. W. Schumacher, Leak detector for hermetic sea1s. Electronics 30, 284-294 (March 1957)

5744 F. Sterzer, Simple high temperature vacuumtight mica window. Rev. Sci. Inst. $\underline{28}$, 208-209 (1957).

5745 G. A. Bottomley, A valve for the greasefree manipulation of mercury. J. Sci. Inst. 34, 369-370 (1957).

5746 G. Comsa \& G. Musa, A new type of ionization pump. J. Sci. Inst. 34, 291-292 (1957).

5747 G. K. T. Conn \& H. N. Daglish, A vapour trap for vacuum systems. J. Sci. Inst. 34, 245 (1957).

$5748 \mathrm{H}$. J. Curnow, on the high residual pressure obtained during the activation of valves containing oxide-coated cathodes. J. Sci. Inst. 34, 73-74 (1957).

5749 A. Franks, An automatic vacuum isolation valve. J. Sci. Inst. 34, 122 (1957).

5750 M. P. Reece, A simple and inexpensive emission regulator for ionization gauges. J. Sci. Inst. 34, 513-514 (1957).
5751 R. N. Edwards \& J. F. Lawyer. Design criteria for accelerator vacuum systems. 16 references. Trans. Fourth Nat1. Symp., Am. Vac. Soc. (1957) 73-82. (Pergamon Press, New York, 1958).

5752 V. V. Fondrk, The steam jet ejector: A versatile pump for high vacuum. Trans. Fourth Nat1. Symp., Am. Vac. Soc. (1957) 88-94. (Pergamon Press, New York, 1958).

5753 A. R. Hamilton, A magnetic amplifier control circuit for a thermal conductivity vacuum gauge. Trans. Fourth Nat1. Symp., Am. Vac. Soc. (1957) 112-114. (Pergamon Press, New York, 1958).

5754 C. Hayashi, Role of adsorption in production and measurement of high vacuum. Trans. Fourth. Nat1. Symp., Am. Vac. Soc. (1957) 13-26. (Pergamon Press, New York, 1958).

5755 A. R. Huntress, A. L. Smith, B. D. Power, \& N. T. M. Dennis, A new silicon diffusion pump fluid. Trans. Fourth Nat1. Symp., Am. Vac. Soc. (1957) 104-111. (Pergamon Press, New York, 1958).

5756 J. M. Kenda11, Permeation of air through walls of plastic tubing used in low pressure systems. Trans. Fourth Nat1. Symp., Am. Vac. Soc. (1957) 120-124. (Pergamon Press, New York, 1958).

5757 R. C. Knecht1i, Distributed differential pumping. Trans. Fourth Nat1. Symp., Am. Vac. Soc. (1957) 83-87. (Pergamon Press, New York, 1958).

5758 N. Milleron, Utilization of the surface tension of 1iquid metals in making high-vacuum seals. Trans. Fourth Nat1. Symp., Am. Vac. Soc. (1957) 38-41. (Pergamon Press, New York, 1958).

5759 J. Morrison, Gas collection and analysis system employed in vacuum tube problems. Trans. Fourth Nat1. Symp., Am. Vac. Soc. (1957) 100-103. (Pergamon Press, New York, 1958).

5760 H. G. Nöller, G. Reich \& W. Bächler, $0 i 1$ diffusion pumps for very low ultimate pressures. Trans. Fourth Nat1. Symp., Am. Vac. Soc. (1957) 6-12. (Pergamon Press, New York, 1958).

5761 G. D. Perkins \& D. E. Charpentier, A simple mass spectrometer for the identification of residual gases in high vacuum systems. Trans. Fourth Nat1. Symp., Am. Vac. Soc. (1957) 125-128. (Pergamon Press, New York, 1958).

5762 G. Reich \& H. G. Nöller, Production of very low pressures with getter-ion pumps. Trans. Fourth Nat1. Symp., Am. Vac. Soc. (1957) 9799. (Pergamon Press, New York, 1958). 
5763 K. C. Taylor, Vacuum stream degassing. Trans. Fourth Nat1. Symp., Am. Vac. Soc. (1957) 157-160. (Pergamon Press, New York, 1958).

5764 F. L. Torney, Jr., A new type of vacuum leak detector, Trans. Fourth Nat1. Symp., Am. Vac. Soc. (1957) 115-119. (Pergamon Press, New York, 1958).

5765 N. A. Florescu, On the measurement of the speed of vacuum pumps. App1. Sci. Res. 7B, 63-72 (1957).

5766 N. A. Florescu, An improvement to the vacuum vapour pump with theoretical and practical consequences. Austr. J. App1. Sci. 8, 305316 (1957).

5767 E. A. Trendelenburg \& J. H. Carmichael, Ion induced re-emission of noble gases from the surface of metal wall ion gauge. (Abstract). Bu11. Am. Phys. Soc. 2, 35 (1957).

5768 R. Barré, R. Geller \& G. Mongodin, Outgassing at room temperature of materials under vacuum. Le vide 12, 195-201 (1957).

5769 R. Horowitz \& H. E. LaGow, Upper air pressure and density measurements from 90 to $220 \mathrm{~km}$ with the Viking 7 rocket. J. Geophys. Res. 62, 57-78 (1957).

5770 J. Schutten, A new electronic circuit for a hot-cathode ionization gauge. App1. Sci. Res. B6, 276-284 (1957).

5771 F. Cordero, H. Matheson \& D. P. Johnson, A nonlinear instrument diaphragm. NBS J. Res. 58, 333-337 (1957).

5772 W. A. Wildhack, R. F. Dressler \& E. C. Lloyd, Investigation of the properties of corrugated diaphragms. 19 references. Trans. Am. Soc. Mech. Eng. 79, 65-82 (1957).

5773 J. Antal \& A. Koenig, New acoustical method of vacuum measurement. Periodica Polytechnica, Elect. Eng. 1, 297-300 (1957).

5774 J. Farguharson \& H. A. Kermicle, Precise automatic manometer reader. Rev. Sci. Inst. $\underline{28}, 324-325$ (1957).

5775 R. Gilmont, I. Gepner, et al, Pressure control by Cartesian diver. Inst. \& Automation 30, 1486-1489 (1957).

5776 H. Moser \& H. Poltz, A McLeod gage for 10 w pressures. In German. $\mathrm{Zt}$. Instrumentenk. 65, 43-46 (1957).

5777 G. F. We11s \& C. E. Melton, Mass spectrometer for study of ion-molecule collision processes. Rev. Sci. Inst. 28, 1065-1069 (1957).

5778 S. P. Wolsky, Positive-ion bombardment of germanium and silicon. Phys. Rev. 108, 11311136 (1957).
5779 R. Geller, Generalities about outgassing at room temperature. Le Vide 12, 194 (1957).

5780 H. Gervais \& J. J. Trillat, Some devices for vacuum work. Le Vide $12,413-418$ (1957).

5781 G. Mongodin, Calibration of helium leak detectors. Le Vide 12, 395-397 (1957).

5782 J. Antal \& A. Koenig, Combined vacuum meter for laboratory use. Acta Phys. Hungar. $\underline{7}$, 117-124 (1957).

5783 M. Varicak, Influence of the wall temperature on the sensitivity of the thermal manometer. In French. J. Phys. Rad. 18, Supp1. No. 7, 70A-72A (1957).

5784 C. T. Johnson \& J. R. Chiles, Jr., The NEL T21 microbarogaphic recording system. Navy Electronics Lab. Res. \& Dev. Report No. 773, 68 p. (1957).

5785 G. Reich \& H. G. Noeller, Partial pressure analysis of the ultimate pressure of oil diffusion pumps with the omegatron. In German. Zt. angew. Phys. 9, 617-621 (1957).

5786 V. V. Mikhnevich, Measuring pressure in the upper atmosphere. Soviet Phys., Advances in Physics, SSSR Acad. Sci. 63 (Sept. 1957). Translation, Russian Literature of Satellites, Part II., Int. Phys. Index, Inc., New York, 9 p. (1960).

5787 B. S. Danilin, V. V. Mikhnevich, A. I. Repher \& E. C. Shvidkovskii, Problem of measuring density and pressure of upper layers of the atmosphere using an artificial earth satellite. Soviet Physics, Advances in Physics, SSSR Acad. Sci. 63 (Sept. 1957). Translation, Russian Literature of Sate1lites, Part II., Int. Phys. Index, Inc., New York, 21 p. (1960).

5788 A. Herlet \& G. Reich, An apparatus for measuring vapor pressure below 10-2 Torr. In German. Zt. angew. Phys. 9, 14-23 (1957).

5789 C. E. Normand, 0. C. Yonts \& C. W. Blue, Some observations on the pumping action of a carbon arc in vacuum. Conference on controlled thermonuclear reactions, Berkeley, Ca1., p. 462-465 (1957). (TID-7536, Pt. 2).

5801 D. J. Santeler, General problems of leak detection and fluid flow in leaks. Gen. Engineering Lab., Gen. Electric Co. Report No. 58GL192 (July 1958).

5802 D. J. Santeler, Outgassing characteristics of ionization gages. General Engineering Lab., General E1ectric Co. Report No. 58GL15413 p. (May 1958). 
5803 D. J. Santeler, Modified mass spectrometer leak detector. General Engineering Lab., General Electric Co. Report No. 58-GL-228, 10 p. (July 1958).

5804 D. J. Santeler, Outgassing characteristics of various materials. Gen. Engineering Lab., General Electric Co. Report No. 58GL303 13 p. (Nov. 1958).

5805 D. J. Santeler, Vacuum process evaluation. Gen. Engineering Lab., General Electric Co. Report No. 58GL146, 42 p. (May 1958).

5806 T. W. Moller \& D. J. Santeler, Evaluation of barium getters using vacuum process evaluation. Gen. Engineering Lab., Gen. Electric Co. Report No. 58GL152, 13 p. (1958).

5807 R. J. Loneragen, Improvements in high vacuum gages. Armament Research. Dev. Estab1. Gt. Brit. ARDE Memo No. MX48/58, 6 p. (1958).

5808 L. Amariglio \& M. M. Benarie, A corrosion proof vacuum controller for pressures under $1 \mathrm{~mm}$ of mercury. J. Sci. Inst. 35,385 (1958).

5809 A. G. Davies, A note on the use of polytetrafluoroethylene in vacuum seals. J. Sci. Inst. 35, 378-379 (1958).

5810 R. Eichhorn \& T. F. Irvine, Jr., Description of a sensitive micromanometer. Rev. Sci. Insts. 29, 23-27 (1958).

5811 R. 0. Jenkins, The construction of small vacuum leaks of constant value. J. Sci. Inst. 35, 428-429 (1958).

5812 J. R. Anderson, Pressure gauge for corrosive gases in the micron and submicron region. Rev. Sci. Insts. 29, 1073-1078 (1958).

5813 H. Wieder \& A. W. Smith, Electrical lead for vacuum systems. Rev. Sci. Insts. 29, 794 (1958).

5814 J. R. Young, Vacuum limitations of rubber 0ring joints. Rev. Sci. Insts. 29, 795-796 (1958).

5815 A. Venema \& M. Bandringa, The production and measurement of ultra-high vacua. Philips Tech. Rev. 20, 145-157 (1958).

5816 R. J. Corruccini, Gaseous heat conduction at low pressures and temperatures. 22 references. Vacuum 7-8, 19-29 (1958) (pub1.1959).

5817 P. de1la Porta, The gettering process in modern receiving valve manufacture. Vacuum 6, 41-58 (1958) (pub1. 1959).

5818 J. W. L. DeVilliers, Method for making vacuum feedthrough terminals. Rev. Sci. Inst. 29, 527-528 (1958).

5819 N. A. Florescu, Compact oil McLeod gage. Rev. Sci. Inst. 29, 528-529 (1958).
5820 R. H. McFarland \& D. G. McDonald, Study of the effectiveness of a copper foil trap for mercury in vacuum. Rev. Sci. Inst. 29, $530-531$ (1958).

5821 C. C. Minter, Thermal conductivity leak detector. Rev. Sci. Inst. 29, 793-794 (1958); 31, 458-459 (1960).

5822 R. C. Frank, R. W. Lee \& R. L. Williams, Ratio of diffusion coefficients for the diffusion of hydrogen and deuterium in steel. J. App1. Phys . 29, 898-900 (1958) .

$5823 \mathrm{~J}$. Rothstein, Rate of exhaust through a tube or orifice. Rev. Sci. Inst. 29, 243-244 (1958).

5824 C. Cochran, Hydrogen-sensitive McLeod gauge. Rev. Sci. Inst. 29, 69-70 (1958).

5825 K. W. Ehlers, Constant-pressure leak-rate gauge. Rev. Sci. Inst. $\underline{29}, 72$ (1958).

5826 L. D. Ha11, Electronic ultra-high vacuum pump. Rev. Sci. Inst. 29, 367-370 (1958).

5827 J. H. Leck, A feedback-controlled Pirani gage. J. Sci. Inst. 35, 107-108 (1958).

5828 J. L. Williams \& G. F. Eveson, A vibrating condenser manometer. J. Sci. Inst. 35, 97 (1958).

5829 E. A. Billett \& J. Bishop, A greaseless vacuum seal for rotating shafts. J. Sci. Inst. 35, 70-71 (1958).

5830 L. Blanaru, A high-vacuum valve. J. Sci. Inst. 35, 184 (1958).

5831 J. 0. Cope, Magnetically operated needle valve. Rev. Sci. Inst. 29, 232-234 (1958).

5832 E. Glueckauf \& G. P. Kitt, Leak testing of vacuum plant by helium analysis. J. Sci. Inst. $35,220-223$ (1958).

5833 S. A. Gordon, Construction of small fixed leaks of predictable throughput. 24 refer ences. Rev. Sci. Inst. 29, 501-504 (1958).

5834 C. J. Meechan \& A. Sosin, Electrically-insulating thermally-conducting vacuum seal for low-temperature use. Rev. Sci. Inst. 29, 323 (1958).

5835 A. R. Strad, Mica window assembly for use at elevated bake-out temperatures. Rev. Sci. Inst. 29, 533 (1958).

5836 I. Ames, R. L. Christensen \& J. Teale, Means for attaining vacua without the use of pump fluids. Rev. Sci. Inst. 29, 736-737 (1958).

5837 M. H. Greenblatt, Sealing a calcium fluoride window to glass. Rev. Sci. Inst. 29, 738 (1958). 
5838 H. T. Knight, Piezoelectric detector for low pressure shock waves. Rev. Sci. Inst. 29, 174-175 (1958).

5839 J. Seehof, S. Smithberg \& M. Armstrong, Electron-permeable window for cathode ray tube. Rev. Sci. Inst. 29, 776-778 (1958).

5840 H. E. Flotow, B. M. Abraham \& R. D. Carlson, Differential pressure gauge for use with liquids and corrosive fluids. Rev. Sci. Inst. 29, 869-870 (1958).

5841 A. G. Kramer \& P. M. Platzman, Microwave manometer. Rev. Sci. Inst. 29,897-898 (1958)

5842 W. R. Mickelsen \& J. Childs, Theoretical analysis of ultra-high vacuum condensers. Rev. Sci. Inst. 29, 871-873 (1958).

5843 G. A. Bottomley, A method of obtaining accurate relative pressures in the range 20 to $200 \mathrm{~mm}$ of mercury. J. Sci. Inst. 35, 254257 (1958).

5844 W. D. Edwards, An insulated vacuum lead-in using an 0 ring. J. Sci. Inst. 35, 111-112 (1958).

5845 A. L. Prior, A neoprene vacuum gasket for wires. J. Sci. Inst. 35, 382-383 (1958).

5846 W. T. Davis, Lag in pressure systems at extreme1y low pressures. Nat1. Advisory Comm. Aeronaut. Tech. Note No. 4334, 16 p. (1.958).

5847 B. M. Bailey \& R. L. Chuan, Cryopumping for high vacuum with low power. Trans. Fifth Nat1. Symp., Am. Vac. Soc. (1958) 262-267. (Pergamon Press, New York, 1959).

5848 N. Beecher \& M. P. Hnilicka, High vacuum pumping techniques. 61 references. Trans. Fifth Nat1. Symp., Am. Vac. Soc. (1958) 94100. (Pergamon Press, New York, (1959).

5849 W. A. Blonn, The evaporation of various alloys at high temperature in vacuo. Trans. Fifth Nat1. Symp., Am. Vac. Soc. (1958) 3034. (Pergamon Press, New York, 1959).

5850 W. E. Briggs, A. C. Jones \& J. A. Roberts, Leak detection techniques. Trans. Fifth Nat1. Symp., Am. Vac. Soc. (1958) 129-136. (Pergamon Press, New York, 1959).

5851 F. C. Brown, Basic techniques in design and construction of the vacuum plant. Trans. Fifth Nat1. Symp., Am. Vac. Soc. (1958) 8993. (Pergamon Press, New York, 1959).

5852 J. H. Carmichae1 \& J. S. Kno11, Trapping of noble gas ions and the re-emission of the trapped atoms from nicke1 and molybdenum. Trans. Fifth Nat1. Symp., Am. Vac. Soc. (1958) 18-21. (Pergamon Press, New York, 1959).
5853 J. H. Carmichael \& W. J. Lange, The use of copper foil isolation traps with ultra-high vacuum systems. Trans. Fifth Nat1. Symp., Am. Vac. Soc. (1958) 137-139. (Pergamon Press, New York, 1959).

5854 K. Diels \& H. Moesta, A new high frequency mass spectrometer and its use in high vacuum technology. Trans. Fifth Nat1. Symp., Am. Vac. Soc. (1958) 115-117. (Pergamon Press, New York, 1959).

5855 K. A. Geiger, An altitude chamber contro1. Trans. Fifth Nat1. Symp., Am. Vac. Soc. (1958) 110-114. (Pergamon Press, New York, 1959).

5856 D. J. Grove, The application of ultra-high vacuum techniques to controlled thermonuclear devices. Trans. Fifth Nat1. Symp. Am. Vac. Soc. (1958) 9-17. (Pergamon Press, New York, 1959).

5857 L. D. Hall, Properties and behavior of electronic ultra-high vacuum pumps. Trans. Nat1. Symp., Am. Vac. Soc. (1958) 158-163. (Pergamon Press, New York, 1959).

5858 A. R. Hamilton, A pressure-responsive relay control circuit. Trans. Fifth Nat1. Symp., Am. Vac. Soc. (1958) 123-125. (Pergamon Press, New York, 1959).

5859 E. G. Huschke, Jr., Simple outgassing determinations aid high temperature vacuum brazing. Trans. Fifth Nat1. Symp., Am. Vac. Soc. (1958) 50-57. (Pergamon Press, New York, 1959).

5860 T. Kraus, A simple formula for the pressuretime dependence during the evacuation of vacuum systems. Trans. Fifth Nat1. Symp., Am. Vac. Soc. (1958) 38-40. (Pergamon Press, New York, 1959).

5861 A. A. Landfors \& M. H. Hablanian, Diffusion pump speed measurements at very low pressures. Trans. Fifth Nat1. Symp., Am. Vac. Soc. (1958) 22-24. (Pergamon Press, New York, 1959).

5862 G. Lewin \& R. Mark, Theory of dissimilar tubular seals of glass, ceramics and metals for critical applications. Trans. Fifth Nat1. Symp., Am. Vac. Soc. (1958) 44-49. (Pergamon Press, New York, 1959).

5863 A. Lorenz, New design of mechanical vacuum pumps. Trans. Fifth Nat1. Symp., Am. Vac. Soc. (1958) 79-82. (Pergamon Press, New York, 1959); Le Vide 14, 121-127 (1959).

5864 N. Milleron, Some component designs permitting ultra-high vacuum with large oil diffusion pumps. 11 references. Trans. Fifth Nat1. Symp., Am. Vac. Soc. (1958) 140-147. (Pergamon Press, New York, 1959). 
5865 N. Milleron \& E. C. Popp, Gettering hydrogen at ultra-1ow pressures by evaporated metal coatings. Trans. Fifth Nat1. Symp., Am. Vac. Soc. (1958) 153-157. (Pergamon Press, New York, 1959).

5866 P. della Porta \& F. Ricca, The kinetics of the adsorption of nitrogen on barium getters. Trans, Fifth Nat1. Symp., Am. Vac. Soc. (1958) 25-29. (Pergamon Press, New York, 1959).

5867 P. A. Redhead, The production and measurement of ultra-high vacuum $\left(10^{-8}-10^{-13} \mathrm{~mm} \mathrm{Hg}\right.$ ) Trans. Fifth Nat1. Symp., Am. Vac. Soc. (1958) 148-152. (Pergamon Press, New York, 1959).

5868 M. P. Rivera \& R. P. LeRiche, A compensated thermocouple vacuum gauge. Trans. Fifth Nat1. Symp., Am. Vac. Soc. (1958) 118-122. (Pergamon Press, New York, 1959).

5869 D. J. Santeler, Outgassing characteristics of various materials. Trans. Fifth Nat1. Symp., Am. Vac. Soc. (1958) 1-8. (Pergamon Press, New York, 1959).

5870 F. W. Trabert, Effect of cooling diffuser walls on performance of a mercury ejector pump. Trans. Fifth Nat1. Symp., Am. Vac. Soc. (1958) 101-104. (Pergamon Press, New York, 1959).

5871 E. A. Winzenburger, The effect of rotational speed on the performance of a Roots blower. Trans. Fifth Nat1. Symp.,Am. Vac. Soc. (1958) 83-85. (Pergamon Press, New York, 1959).

5872 R. H. Work, Silica-glass helium leaks as standards in leak detection. Trans. Fifth Nat1. Symp., Am. Vac. Soc. (1958) 126-128. (Pergamon Press, New York, 1959).

5873 R. E. Schlier, Adsorption of oxygen and carbon oxide on tungsten. J.App1. Phys. 29, 1162-1167 (1958).

5874 D. Alpert, Production and measurement of ultra-high vacuum. About 180 references. Handbuch der Physik, S. Fluegge, Editor, Springer-Verlag, Berlin, v. 12, 609-663 (1958).

5875 R. Jaeke1, Vacuum physics, In German. Handbuch der Physik, S. Fluegge, Editor, Springer-Verlag, Berlin, v. 12, 515-608 (1958).

5876 L. D. Ha11, Ionic vacuum pumps. 22 references. Science 128, 279-285 (1958).

5877 W. Becker, A new molecular pump. In German. Vakuum-Tech. $\underline{7}, 149-152$ (1958).

5878 J. H. Carmichae1 \& E. A. Trendelenburg, Ion induced re-emission of noble gases from a nicke1 surface. J. App1. Phys. 29, 15701577 (1958).
5879 J. A. Dillon, Jr. \& H. E. Farnsworth, Work function and sorption properties of silicon crysta1s. J. App1. Phys. 29, 1195-1202 (1958).

5880 H. E. Farnsworth, R. E. Schlier, T. H. George \& R. M. Burger, Application of the ion bombardment cleaning method to titanium, germanium, silicon, and nickel as determined by low-energy electron diffraction. J. App1. Phys. 29, 1150-1161 (1958).

5881 M. E. Haine, E. W. R. Francis \& R. N. Bloomer, Removal of gases in high vacuum systems by metal abrasion. Nature 182, 931932 (1958).

5882 P. Kisliuck, Using cathode resistance to measure adsorption of gases on metals. Be11 System Tech. J. 37, 925 (1958).

5883 C. H. Rehkopf, Measurements of gas evolution or sorption of anode materials under simulated Iife conditions. Sylvania Technol. 11, 114-116 (1958).

5884 G. F. We11s, Precision 1iquid nitrogen trap leve1 controller. Rev. Sci. Inst. 29, 893895 (1958).

5885 D. G. Bills \& N. P. Carleton, Adsorption of activated gases. J. App1. Phys. 29, 692697 (1958).

5886 J. H. Beynon \& S. Clough, A mass spectrometer mass marker. J. Sci. Inst. 35, 289291 (1958).

5887 F. Bernhard, \& H. Bumm, The technique of brazing in vacuum. In German. VakuumTech. 7, 153-158 (1958).

5888 L. Holland, L. Laurenson \& J. T. Holden, A new type of titanium getter pump. Nature $\underline{182}, 851-852$ (1958).

5889 J. Eisinger, Properties of hydrogen chemisorbed on tungsten. J. Chem. Phys. 29, 1154-1160 (1958).

5890 W. Espe, Quartz, fused quartz and quartzlike glasses as constructional meterials in high vacuum work. 63 references. In German. Vakuum-Tech. 7, 65-77, 101-110 (1958).

5891 P. A. Silberg \& C. H. Bachman, Diffusion of hydrogen in palladium. 20 references. $J$. Chem. Phys. 29, 777-781 (1958).

5892 R. C. Frank, Some observations regarding the present status of measurement of the diffusion coefficients of hydrogen in iron and mild stee1. J. App1. Phys. 29, 1262-1263 (1958).

5893 H. Klumb \& D. Fuchs, On radiometer forces in the pressure range $10^{-3}$ to 3 Torr. In German. Vakuum-Tech. 7, 131-135 (1958). 
5894 Y. Tuzi \& H. Okamoto, The adsorption of water vapour on lead borosilicate glass in vacuum. J. Phys. Soc., Japan, 13, 960-965 (1958).

5895 M. G. Manov, Mean gas flow velocity and gas flow rate in jets of high vacuum pumps. J. Tech. Phys. USSR, 5, 28, No. 2. Translation Sov. Phys. Tech. Phys. 3, 289-296 (1958).

5896 0. German, Kinetic theory of the flow of gas through a cylindrical tube. Soviet Physics, JETP 34, 1016-1019 (1958).

5897 A. Zincke, Glass problems in electron tube technology. Vakuum-Tech. 7, 93-100 (1958).

5898 G. Haase, Mcleod gage with a linear scale. In German. Chemische Tech. (Beiblatt GlasApparate-Technik) 10, 37-39 (1958).

5899 P. Lienard, Manometer responding to a large frequency band for measuring rapidly varying pressure. In French. NATO AGARD Rept. No. 170,15 p. (1958).

58100 A. Thom \& C. J. Ape1t, The pressure in a two-dimensional static hole at low Reynolds numbers. Aero. Research Comm., Grt. Brit., Repts \& Yemo., No. 3090, 13 p. (1958).

58101 E. P. Muntz, Pressure measurements in free molecule flow with a rotating arm apparatus. Univ. Toronto Inst. Aerophysics TN $22,49 \mathrm{p}$. (1958).

58102 L. J. Griffiths, A modified McLeod gauge for low pressure measurements. Advances in Vacuum Science \& Technology. Proc. 1st Int. Cong. on Vac. Techniques, 263-265 (1958). (Pergamon Press 1960).

$58103 \mathrm{H}$. Hintenberger \& E. Doernenburg, App1ications of mass spectroscopy to vacuum technology. 94 references. Vakuum-Tech. 7 , 121-130, 159-171 (1958).

58104 British Standards Institution, Glossary of terms used in high vacuum technology. British Std. No. 2951, 29 p. (1958).

58105 D. A1lenden, Control circuit for BayardAlpert ionization gage. In French. Le Vide $13,247-255$ (1958).

58106 H. W. Drawin, Electrical capacity-diaphragm vacuum gage. In German. Vakuum-Tech. 177-185 (1958).

$58107 \mathrm{M}$. Goto, The standard McLeod gauge and the calibration of ionization gauges against it. Advances in Vacuum Science and Technology. Proc. 1st Int. Cong. on Vac. Techniques, (1958) 266-270. (Pergamon Press, New York, 1960).
58108 R. Bénichou, J. C. Blaire \& R. P. Henry, Study on the degassing of rubber joints. In French. Advances in Vacuum Science Technology, Proc. 1st Int. Cong. on Vacuum Techniques (1958) 355-363. (Pergamon Press, New York, 1960).

58109 D. A. Degras, Measurement of pumping speed. In French. 8 references. Advances in Vacuum Science Technology, Proc. 1st Int. Cong. on Vacuum Techniques (1958) 315-322. (Pergamon Press, New York, 1960).

58110 H. W. Drawin, Electrical capacity-diaphragm vacuum gage. In German. Advances in Vacuum Science Technology, Proc. 1st Int. Cong. on Vacuum Techniques (1958) 274-284. (Pergamon Press, New York, 1960).

$58111 \mathrm{H}$. Ebert, On vacuum measurement with the McLeod gage. In German. Advances in Vacuum Science \& Technology, Proc. Ist Int. Cong. on Vacuum Techniques (1958) 260-263. (Pergamon Press, New York, 1960).

58112 R. P. Henry, Stabilization of power supply for ionization gages used in industry. In French. Advances in Vacuum Science Technology, Proc. 1st Int. Cong. on Vacuum Techniques (1958) 299-301. (Pergamon Press, New York, 1960).

58113 A. M. Grigorev, Enlarging the range of the pressures measured by cold-cathode ionization gauges. Advances in Vacuum Science Technology, Proc. 1st Int. Cong. on Vacuum: Techniques (1958) 308-310. (Pergamon Press, New York, 1960).

58114 J. Groszkowski, Extension of range of a conductivity vacuum gage by compression. In French. Advances in Vacuum Science Technology, Proc. 1st Int. Cong. on Vacuum Techniques (1958) 288-289. (Pergamon Press, New York, 1960).

58115 S. Kobayashi, High sensitive hot cathode ionization gauge. Advances in Vacuum Science Technology, Proc. 1st Int. Cong. on Vacuum Techniques (1958) 271-273. (Pergamon Press, New York, 1960).

58116 S. Komiya \& T. Ikeda, The effect on the test dome in the measuring of the speed of an oil-diffusion pump. Advances in Vacuum Science Technology, Proc. 1st Int. Cong. on Vacuum Techniques (1958) 325-328. (Pergamon Press, New York, 1960).

58117 J. J. Opste1ten \& N. Warmoltz, A diaphragm mangmeter with a linear scale for the range $10^{-5}$ to $10 \mathrm{~mm} \mathrm{Hg}$. In French. Advances in Vacuum Science Technology, Proc. 1st Int. Cong. on Vacuum Techniques (1958) 295-298. (Pergamon Press, New York, 1960). 
58118 G. F. Vanderschmidt \& J. C. Simons, Jr., A new radiological vacuum gauge. Advances in Vacuum Science Technology, Proc. 1st Int. Cong. on Vacuum Techniques (1958) 305-307. (Pergamon Press, New York, 1960).

58119 M. Varicak \& B. Saftić, The use of thermistors for low pressure-measurements. Advances in Vacuum Science Technology, Proc. 1st Int. Cong. on Vacuum Techniques (1958) 285-287. (Pergamon Press, New York, 1960).

58120 N. A. F1orescu, U1tra-high vacuum investigations. 28 references. Advances in Vacuum Science Technology, Proc. 1st Int. Cong. on Vacuum Techniques (1958) 367-372. (Pergamon Press, New York, 1960).

58121 H. L. Eschbach, Diffusion coefficients and outgassing of helium and hydrogen for various glasses. In German. Advances in Vacuum Science Technology, Proc. Ist Int. Cong. on Vacuum Techniques (1958) 373-377. (Pergamon Press, New York, 1960).

58122 S. Garbe, Analysis of residual gases with an omegatron. In German. Advances in Vacuum Technology, Proc. 1st Int. Cong. on Vacuum Techniques (1958) 404-409. (Pergamon Press, New York, 1960).

58123 H. Huber \& M. Warnecke, A titanium pump designed to maintain a vacuum in an electronic tube. Le Vide 74, 84-90 (1958); Advances in Vacuum Science Technology, Proc. 1st Int. Cong. on Vacuum Techniques (1958) 457-462. (Pergamon Press, New York, 1960).

58124 I. A. Ka1jabina \& Y. A. Yakhvidin, Experience in using mass-spectrometric methods in electro-vacuum technology. Advances in Vacuum Science Technology, Proc. 1st Int. Cong. on Vacuum Techniques (1958) 418-426. (Pergamon Press, New York, 1960).

58125 A. Klopfer, The omegatron as a partial pressure measuring gage. In German. Advances in Vacuum Science Technology, Proc. 1st Int. Cong. on Vacuum Techniques (1958) 397-400 (Pergamon Press, New York, 1960).

58126 A. Klopfer \& W. Ermrich, Experiments with titanium ion pumps. In German. Advances in Vacuum Science Technology, Proc. 1st Int. Cong. on Vacuum Techniques (1958) 427-429. (Pergamon Press, New York, 1960).

58127 S. Sibata, C. Hayashi \& H. Kumagai, A barium getter-ion pump. Advances in Vacuum Technology, Proc. 1st Int. Cong. on Vacuum Techniques (1958) 430-432. (Pergamon Press, New York, 1960).

58128 H. Kumagai, C. Hayashi, Y. Ishibe, N. Dogi, et a1, Characteristics of titanium evaporion pump. Advances in Vacuum Science Technology, Proc. Ist Int. Cong. on Vacuum Techniques (1958) 433-438. (Pergamon Press, New York, 1960).
58129 J. H. Leck \& G. Carter, Adsorption and desorption of positive ions on glass and meta1 surfaces. Advances in Vacuum Science Technology, Proc. 1st Int. Cong. on Vacuum Techniques (1958) 463-467. (Pergamon Press, New York, 1960).

58130 E. Baronetzky \& A. Klopfer, Influence of gas reactions in vacuum systems on the combination of residual gases. In German. Advances in Vacuum Science Technology, Proc. 1st Int. Cong. on Vacuum Techniques (1958) 401-403. (Pergamon Press, New York, 1960).

$58131 \mathrm{~J}$. Markali, Mechanism of titanium getter and titanium evapor-pump. In German. Advances in Vacuum Technology, Proc. 1st Int. Cong. on Vacuum Techniques (1958) 450-452.

(Pergamon Press, New York, 1960).

58132 P. Prugne \& P. Garin, A getter pump with a low temperature trap. In French. Advances in Vacuum Science Technology, Proc. 1st Int. Cong. on Vacuum Techniques (1958) 439-442. (Pergamon Press, New York, 1960).

58133 P. A. Redhead, The Townsend discharge in a coaxial diode with axial magnetic field. Canad. J. Phys. 36, 255-270 (1958).

58134 J. P. Hobson \& P. A. Redhead, Operation of an inverted-magnetron gauge in the pressure range $10^{-3}$ to $10^{-12} \mathrm{~mm} \mathrm{Hg}$. Canad. J. Phys. $36,271-288$ (1958).

58135 J. P. Hobson \& P. A. Redhead, Factors 1imiting ultimate pressure in ultra-high vacuum systems. Advances in Vacuum Science Technology, Proc. 1st Int. Cong. on Vacuum Techniques (1958) 384-388. (Pergamon Press, New York, 1960).

58136 P. A. Redhead, Pressure measurements at ultra-high vacuum $\left(10^{-8}\right.$ to $\left.10^{-14} \mathrm{~mm} \mathrm{Hg}\right)$. Advances in Vacuum Science Technology, Proc. 1st Int. Cong. on Vacuum Techniques (1958) 410-413. (Pergamon Press, New York, 1960).

58137 G. Reich \& H. G. Noeller, Ion gatter pump for low pressures. In German. Advances in Vacuum Science Technology, Proc. Ist Int. Cong. on Vacuum Techniques (1958) 443-445. (Pergamon Press, New York, 1960).

58138 N. W. Robinson \& F. Berz, Initial pumping and recovery of ionization gauges. Advances in Vacuum Science Technology, Proc. Ist Int. Cong. on Vacuum Techniques (1958) 378-383. (Pergamon Press, New York, 1960).

58139 A. Schram, On a new principle of operation for the titanium getter pump. In French. Advances in Vacuum Science Technology, Proc. 1st Int. Cong. on Vacuum Techniques (1958) 446-449. (Pergamon Press, New York, 1960).

$58140 \mathrm{~J}$. Schutten, Measurement of ultra-high vacua. 17 references. Advances in Vacuum Science - Technology, Proc. 1st Int. Cong. on Vacuum Techniques (1958) 414-417. (Pergamon Press, New York, 1960). 
58141 A. Venema, The production of ultra-high vacua by means of a diffusion pump. Advances in Vacuum Science Technology, Proc. 1st Int. Cong. on Vacuum Techniques (1958) 389-392. (Pergamon Press, New York, 1960).

58142 M. I. Winogradoff, Evapor-ion pump. Advances in Vacuum Science Technology, Proc. 1st Int. cong. on Vacuum Techniques (1958) 453-456. (Pergamon Press, New York, 1960).

58143 F. B. Newe11, Diaphragm characteristics, design and terminology. Manual, Am. Soc. Mech. Eng., 74 p. (1958).

58144 D. J. Bogardus \& J. R. Mahoney, Oak Ridge gaseous diffusion plant reports on 15 years of process mass spectrometry. Inst. Soc. Am. J. 5, 26-30 (Aug. 1958).

58145 R. Haefer, Progress in the design of oil diffusion pumps. In French. Revue Univ. des Mines 14, 21-29 (1958).

58146 W. Paul, H. P. Reinhard \& U. von Zahn, Electric mass filter as mass spectrometer and isotope separator. Zt. Phys. 152, 143-182 (1958).

$58147 \mathrm{~K}$. Scheibe \& W. Wuest, Liquid manometer with photoelectric sensing. In German. Zt. Instrumentenk. 66, 185-188 (1958).

58148 American Vacuum Society, Glossary of terms used in vacuum technology. Pergamon Press, New York, 63 p. (1958).

58149 A. J. Rosenberg, The adsorption of krypton on germanium. J. Phys. Chem. 62, 1112-1119 (1958).

$58150 \mathrm{~N}$. Hackerman \& A. C. Ha11, The adsorption of water vapor on quartz and calcite. J. Phys. Chem. 62, 1212-1214 (1958).

58151 W. W. Willmarth, Sma11 barium titanate transducer for aerodynamic or acoustic pressure measurements. Rev. Sci. Inst. 29, 218-222 (1958).

58152 R. Geller, Vacuum degassing of materials. Le Vide 13, 71-76 (1958).

58153 L. Holland, The cleaning of glass in a glow discharge. Brit. J. App1. Phys. 9, 410-415 (1958).

58154 L. Pátý \& R. Neưzilová, A new construction of a high-vacuum high-speed ion pump. Czech. J. Phys. 8 , 746-747 (1958).

58155 B. B. Dayton, International cooperation on vacuum standards and 1iterature abstracting. Advances in Vacuum Science Technology, Proc. 1st Int. Cong. on Vacuum Techniques (1958) 71-75. (Pergamon Press, New York, 1960).

58156 J. van Katwijk, Experience with the automa$t i o n$ of mass spectrometry gas analysis. In German. Zt. Anal. Chem. 164, 73-80 (1958).
58157 R. Haefer, On automation of high vacuum apparatus based on the requirements for a particle accelerator. In German. Advances in Vacuum Science Technology, Proc. 1st Int. Cong. on Vacuum Techniques (1958) 508-513. (Pergamon Press, New York, 1960).

$58158 \mathrm{~J}$. Bishop, Vacuum techniques in mass spectrometry. Advances in Vacuum Science Technology, Proc. 1st Int. Cong. on Vacuum Techniques (1958) 484-490. (Pergamon Press, New York, 1960).

58159 J. Blears, E. J. Greer \& J. Nightingale, Factors determining the ultimate pressure in large high-vacuum systems. Advances in $\mathrm{Va}-$ cuum Science Technology, Proc. 1st Int. Cong. on Vacuum Techniques (1958) 473-480. (Pergamon Press, New York, 1960).

58160 H. Bridge, R. Budde, A. Burger, et al, Some vacuum problems at low temperature. Advances in Vacuum Science Technology, Proc. 1st Int. Cong, on Vacuum Techniques (1958) 481-483. (Pergamon Press, New York, 1960).

58161 W. L. Donn, The microbarovariograph: a new instrument for measuring minute atmospheric pressure variations. Trans. Am. Geophys. Union 39, 366-368 (1958).

58162 I. P. Passechnik \& N. E. Fedosseenko, An electrodynamic microbarograph with galvanometer recording. Bull. (Izv) Acad. Sci. USSR, Geophys. Ser. No. 1 (1958).

$58163 \mathrm{~K}$. E. Wakefield, An investigation of the effect of a Kovar ring on a uniform magnetic field. Princeton Univ., Proj. Matterhorn, Tech. Memo No. 21, 15 p. (1958). (NYO-6366).

58164 U. 0. Hutton \& J. F. Gilheany, A two-inch range precision mercury manometer. NBS Report No. 6193, 32 p. (1958); NBS Tech. News Bul1. 43, 71 (1959).

5901 G. F. Vanderschmidt, Using isotopes to measure low pressures. E1ectronics 32, 60-61 (June 19, 1959).

5902 A. W. Smith, Extended range Pirani gage. Rev. Sci. Insts. 30, 485-486 (1959).

5903 N. de Haas, Meta1-glass vacuum seal for use at low temperatures. Rev. Sci. Inst. 30 , 594-595 (1959).

5904 W. J. Lange, Large ultra-high vacuum valve. Rev. Sci. Inst. 30, 602-603 (1959).

5905 L. A. Green \& A. C. Richardson, A dismountable vacuum joint for bakeable glass vacuum systems. J. Sci. Inst. 36, 324-325 (1959).

5906 M. A. Biondi, High-speed nonrefrigerated isolation traps for ultra high-vacuum systems. Rev. Sci. Inst. 30, 831-832 (1959). 
5907 R. A. Rapp, New techniques in the attainment of high vacuum. Rev. Sci. Inst. 30, 839840 (1959).

5908 F. G. A11en, J. Eisinger, H. D. Hagstrum \& J. T. Law, Cleaning of silicon surfaces by heating in high vacuum. 20 references. J. App1. Phys. 30, 1563-1571 (1959) .

5909 N. Beecher, High vacuum pumping for modern electronic needs. Electronics $32,66-69$ (oct. 9, 1959).

5910 U. 0. Hutton, A tilting air-lubricated peston gage for pressures below one-half inch of mercury. NBS J. Research 63C, 47-57 (1959).

5911 N. W. Spencer \& R. L. Boggess, A radioactive ionization gage pressure measurement system. J. Am. Rocket Soc. 29, 68-71 (1959).

5912 J. L. Peters, Mass spectrometer leak detector with improved sensitivity. Rev. Sci. Inst. 30, 1093-1095 (1959).

5913 A. Crocker, Al1-metal high-conductance vacuum tap. J. Sci. Inst. 36, 447-448 (1959).

5914 N. D. Morgulis, G. Ptushinskii \& B. A. Chuikov, Certain features of the partial adsorption of residual gas components at very high vacuum. In Russian. Dokalady Akad. Nauk SSSR 128 No. 5, 930-932 (1959). Translation, Soviet Physics, Dokalady, Am. Inst. Physics 4, 1108-1110 (1960).

5915 D. Alpert, Recent advances in ultra-high vacuum technology. 37 references. Vacuum 9, 89-96 (1959) .

5916 N. C. Balchin \& B. L. Mordike, Semi-automatic control of vacuum pumping systems. Vacuum 9, 264-268 (1959).

5917 R. C. Bradley, Secondary positive ion emission from metal surfaces. J. App1. Phys. 30, 1-8 (1959).

5918 G. Carter, Dual pumping speeds of some ionization pumps. Nature 183, 1619-1620 (1959).

5919 G. Carter, Electrical clean-up of gases in hot cathode discharge tubes. 42 references. Vacuum 9, 190-200 (1959).

5920 C. L. Gould, Vacuum system for a thirty billion electron volt particle accelerator. Vacuum 9, 63-68 (1959).

5921 R. G. Herb, Evapor-ion pump development at the University of Wisconsin. Vacuum 9, 97107 (1959).

5922 L. Holland, Theory and design of getter-ion pumps. 63 references. J. Sci. Inst. 36, 105-116 (1959).

5923 R. Jaecke1, The physics and techniques of diffusion pumps. In German. 24 references. Vacuum 9, 209-218 (1959).
5924 C. G. J. Jansen \& A. Venema, A McLeod manometer with prescribed volumes for use as a standard instrument. Vacuum 9, 219-230 (1959).

5925 1. A. Kaljabina \& Y. A. Yukhvidin, Experience in using mass-spectrometric methods in electro-vacuum technology. Vacuum 9, 117125 (1959).

5926 M. J. D. Low \& H. A. Taylor, Enhanced surface reactions. III. Adsorption of gases on prepared ruthenium surfaces. J. Electrochem. Soc. 106, 138-142 (1959).

5927 M. L. Lyubimov, K. P. Shakhov \& Y. A. Yukhvidin, Experience in designing and manufacturing a11-inetal vacuum systems. Vacuum 9, 108-116 (1959).

5928 R. C. Marker, Vacuum techniques and components used for a continuously pumped linear electron accelerator. Vacuum 9, 128-133 (1959).

5929 L. D. Miller \& P. N. Peterson, Automatic leve1 contro1 for liquid nitrogen trap. Vacuum 9, 231-232 (1959).

5930 D. J. Pacey, A piezoelectric oscillator manometer. Vacuum 9, 261-263 (1959).

5931 N. W. Robinson \& F. Berz, Initial pumping and recovery of ionization gauges. Vacuum $\underline{9}, 48-53(1959)$.

5932 D. S. Stark, Measurements on the properties of a simple omegatron. Vacuum 9, 288-294 (1959).

5933 E. Thomas, R. Servranckx \& R. Leyniers, On the choice of units of pressure and of flow in vacuum technique. Vacuum 9, 207-208 (1959).

5934 S. Veis, The measurement of the pressures of various gases by means of a Pirani gauge. Vacuum 9, 186-189 (1959).

5935 S. A. Vekshinsky, M. I. Menshikov \& I. S. Rabinovich, High-vacuum pumps and units for accelerators. Vacuum 9, 201-206 (1959).

5936 A. Venema, The production of ultra-high vacua by means of a diffusion pump. Vacuum $\underline{9}, 54-57$ (1959).

5937 L. Dunoyer, The experimental basis of the kinetic theory of gases. Vacuum $9,36-40$ (1959).

$5938 \mathrm{~J}$. Eisinger, Adsorption of oxygen on silicon. J. Chem. Phys. 30, 410-412 (1959).

5939 J. Eisinger, Adsorption of oxygen on tungsten. J. Chem. Phys. 30, 412-416 (1959). 
5940 W. Espe, Mica as constructional material for high vacuum applications. In German. 74 references. Vakuum-Tech. $8,15-19,29-38$, 67-76 (1959).

5941 F. Enge1, Gas electrolys is in electron tubes. Vakuum-Tech. $8,44-47$ (1959).

5942 D. 0. Hayward \& R. Gomer, Adsorption of carbon dioxide on tungsten. J. Chem. Phys. 30, 1617 (1959).

5943 J. R. Hearst, S. H. Ahn \& E. N. Strait, Vacuum seals at liquid nitrogen temperatures. Rev. Sci. Inst. 30, 200 (1959).

5944 J. P. Hobson, First adsorbed layer of He at $4.2^{\circ} \mathrm{K}$. Can. J. Phys. 37, 300-312 (1959).

5945 J. F. Kemp, Liquid manometer with electromagnetic balance indicator. $\mathrm{J}$. Sci. Inst. 36, 77-81 (1959).

5946 H. Klumb \& J. Lueckert, Two methods for measuring low vapor pressure. In German. VakuumTech. 8, 62-66 (1959).

5947 T. Kraus, The pumping speed in high vacuum systems. In German. Vakuum-Tech. 8, 39-43 (1959).

5948 J. T. Law, Adsorption of hydrogen on silicon. J. Chem. Phys. 30, 1568-1576 (1959).

5949 S. Petralia \& U. Valdre, On the pumping speed of oil diffusion pumps. Il Nuovo limento 12, 616-622 (1959).

5950 V. Roberts, Coolable vacuum-tight window seals for optical use. J. Sci. Inst. 36 , 99 (1959).

5951 G. Saini, F. Ricca \& A. Nasini, Adsorption of nitrogen on tungsten at ultra-vacuum. La ricerca Scientifica 29, 1523-1533 (1959).

5952 H. A. Smith, J. C. Posey \& C. 0. Thomas, Mercury glass check valves. Rev. Sci. Inst. 30, 202 (1959).

5953 J. R. Young, Cleaning techniques for rubber o-rings used in vacuum systems. Rev. Sci. Inst. 30, 291 (1959).

5954 F. C. Hurlbut, Electron beam density probe for measurements in rarefied gas flows. J. App1. Phys. 30, 273-279 (1959).

5955 J. F. Kemp, Centrifugal manometer. Trans. Am. Soc. Mech. Eng. 81, 341-348 (1959).

5956 N. S. Silsby, External interference effects of flow through static-pressure orifices of an airspeed head at several supersonic Mach numbers and angles of attack. Nat. Aero. Space Agency Memo. 2-13-59L, 14 p. (1959).

5957 N. W. Spencer, R. L. Boggess, H. E. LaGow $\& \mathrm{R}$. Horowitz, on the use of ionization gage devices at very high altitude. 21 references. J. Am. Rock. Soc. 29,290-294(1959).
5958 H. Suzuki, Analysis of the air micro pressure gage by the Laplace transformation method. Hosei U. Tech. Co11. Rept. No. 4, 48-58 (1959).

5959 N. M. Wiederhorn, J. H. Vreeland \& R. R. Perron, A new instrument for the determination of molecular weight by differential vapor pressure. USAF Wright Aero. Dev. Center TR 58-623, 32 p. (1959).

5960 G. N. Patterson, Theory of free molecule, orifice-type pressure probes in isentropic and nonisentropic flows. Univ. Toronto Inst. Aerophysics Rept. 41, 15 p. (1959).

5961 J. Bailleul-Langlais, A radiometer vacuum gage. Le Vide 14, 59-73 (1959).

5962 C. R. Brymmer \& W. Steckelmacher, Demountable vacuum seal for operation at temperatures from -188 to $880^{\circ} \mathrm{C}$. J. Sci. Inst. 36 , 278-281 (1959).

5963 H. J. Bue1temann, The influence of water vapor on the readings of compression vacuum gages. Vakuum-Tech. 8 , 104-108 (1959).

5964 D: A. Degras \& P. Andrieux, A new thermistor vacuum gage. Le Vide 14, 45-58 (1959).

5965 J. Holden, L. Holland \& L. Laurenson, Bakeable vacuum seals using aluminum-wire gaskets. J. Sci. Inst. 36, 281-283 (1959).

5966 F. Kirchner, Flow in high vacuum apparatus. In German. Zt. f. angew. Phys. 11, 167-169 (1959).

5967 M. Varićak \& B. Saftić, Principles of semiconductor manometer in pressure range of 1 to $10^{-6} \mathrm{~mm} \mathrm{Hg}$. Rev. Sci. Inst. $30,891-896$ (1959).

5968 H. B. Benton, Sma11, 1ight weight ionization gauge control circuit. Rev. Sci. Inst. 30, 887-888 (1959).

5969 J. P. Boulloud \& J. Schweitzer, Experimental study of metal gasketed joints for ultrahigh vacuum. Le Vide 14, 241-249 (1959).

5970 D. A. Degras, Evapor-ion pump with 1iquid helium trap. Le Vide 14, 128-140 (1959).

5971 R. P. Henry, Measurement of outgassing speed by 0atley's method. Le Vide 14, 226-240 (1959).

5972 E. C. Evans \& P. E. Melroy, Cartesian manostat for precise differential pressure control. Inst. Soc. Am. J. 6,39 (0ct. 1959).

5973 L. Holland \& L. Laurenson, The performance and design of a titanium getter pump. Le Vide 14, 141-145 (1959).

5974 H. Huber, A. M. Shroff \& M. Warnecke, Pumping of electron tubes with the titanium pump. Le Vide 14, 214-225 (1959). 
5975 R. L. Jepson, Important characteristics of new type getter-ion pump. Le Vide 14, 8094 (1959).

5976 B. G. Lazarev \& M. F. Fedorova, Vacuum adsorption pump. In Russian. Zhurnal Tekhnicheskoi Fiziki 29, No. 7 862-865 (1959). Translation: Soviet Physics, Technical Physics 4, 778-780 (1960).

5977 A. Lorenz, New design of mechanical vacuum pump. Le Vide 14, 121-127 (1959).

5978 G. Mongodin, Welded pumping assembly for high vacuum, easy to outgas. Le Vide 14, 95-97 (1959)

\section{Mueller}

5979 K. G. Description of a gauge for ultra-high vacua and remarks about ultrahigh vacua techniques for all-metal mountings. Le Vide 14, 250-259 (1959).

5980 J. Schweitzer, U1tra high vacuum techniques. 22 references. Le Vide 14, 165-182 (1959).

5981 E. A. Trendelenburg, Production of ultra high vacua with oil diffusion pumps. Le Vide 14, 74-79 (1959).

5982 A. Venema, Measurement of pumping speed of vacuum pumps. Le Vide $14,113-120$ (1959).

5983 E. Wintergerst \& H. Lintz, Properties and application of metal diaphragms. Reglungstech. 7, 160-165 (1959).

5984 D. Charles, R. J. Warnecke \& J. C. Marchais, Omegetron type low pressure gas analyzer AM 100. Le Vide 14, 274-289 (1959).

5985 M. Pequignot \& M. Yerna, The use of silica seals in the production of special valves with numerous lead-in wires. Le Vide 14 , 290-294 (1959).

5986 R. Servranckx \& R. Leyniers, Security valve for vacuum pumping units. Le Vide 14, 295299 (1959).

5987 J. W. Beams, Molecular pumping. Science 130 1406-1407 (1959).

5988 R. Gomer, Adsorption and diffusion of argon on tungsten. J. Phys. Chem. 63, 468-472 (1959).

5989 M. V. C. Sastri, T. S. Viswanthan \& T. S. Nagarjunan, The influence of a chemisorbed layer of carbon monoxide on subsequent physical adsorption. J. Phys. Chem. 63, 518-521 (1959).

5990 H. L. Pickering \& H. C. Eckstrom, Heterogeneous reaction studies by infrared absorption. J. Phys. Chem. 63, 512-517 (1959).

5991 R. A. Pierotti \& G. D. Halsey, Jr., The interaction of krypton with metals. An appraisal of several interaction theories. J. Phys. Chem. 63, 680-686 (1959).
5992 J. L. Shereshefsky \& B. R. Mazumder, The adsorption of some gases on evaporated metal films and on oxidized films of nickel. J. Phys. Chem. 63, 1630-1638 (1959).

5993 S. J. Stephens, Surface reactions on evaporated palladium films. J. Phys. Chem. 63, 188-194 (1959).

5994 R. L. Stow, Titanium as a gettering material. Nature 184, Supp1. No. 8, 542-543 (1959).

5995 D. G. Bills \& A. A. Evett, Glass, a disturbing factor in physical electronics measurements. J. Appl. Phys. 30, 564-567 (1959).

5996 Y. L. Sandler \& M. Gazith, Surface properties of germanium. J. Phys. Chem. 63, 10951102 (1959).

5997 W. F. Wolff \& P. Hill, Adsorption of inert gases by modified carbons. J. Phys. Chem. 63, 1161-1164 (1959).

5998 D. W. McKee, The sorption of hydrocarbon vapors by silica gel. J. Phys. Chem. 63, 1256-1259 (1959).

5999 R. Klein, Adsorption, diffusion and evaporation of carbon monoxide on tungsten. J. Chem. Phys. 31, 1306-1313 (1959).

$59100 \mathrm{~J}$. C. Boulassier, Vacuum outgassing of material at ambient temperature. Le vide 14 , 39-44 (1959).

59101 R. K. Burshtein \& D. L. Kondrashov, Pirani gage for measuring pressure of corrosive gases. Zhur. Fiz. Khim. 33, 1653-1654(1959).

59102 G. Carter \& J. H. Leck, Bistable behavior of the Bayard-Alpert ionization gage. Brit. J. App1. Phys. 10, 364-367 (1959).

59103 P. K. Dutt \& S. K. Mukherjee, A palladium Pirani gage. In English. $\mathrm{Z} t$. angew. Phys. $11,470-474$ (1959).

59104 A. M. Grigor'ev, Manometers for measuring ultra high vacuum. Priboryi Tekh. Eksperimenta, No. 6, 10-13 (1959). Translation, Inst. \& Exp. Tech. Inst. Soc. Am. p. 870$872(1960)$.

59105 Z. Knorr, Construction of vacuum apparatus. Chem. Listy (Prague) 53, 941-944 (1959).

59106 M. I. Menshikov, Development of the technique of obtaining vacuum. 49 references. Pribory i Tekh. Eksperimenta No. 4, 3-21 (1959).

59107 P. A. Redhead, Magnetron gage: a coldcathode vacuum gage. Can. J. Phys. 37, 1260-1271 (1959).

59108 A. A. Sakovich, R. I. Grigor'eva, V. S. Grigor'ev \& I. V. Blond, Titanium absorption pump. Vestnik Electro-Prom 30, No. 6, 1316 (1959). 
59109 E. F. Doil'nitsyn, A. I. Trubetskoi \& M. Y. Shcherbakova,Miniature radio frequency mass spectrometer. Pribory i rekh. Eksperimenta. No. 2, 81-82 (1959). Translation, Inst. Soc. Am., Inst \& Exp. Tech. No. 2, 262-264 (1960).

59110 V. M. Gavrilyuk \& Y. M. Kucherov, Ionization vacuum gage for measuring pressures of $10^{-4}$ to $10-10 \mathrm{~mm} \mathrm{Hg}$. Pribory $\mathrm{i}$ Tekh. Eksperimenta. No. 2, 83-85 (1959). Translation, Inst. Soc. Am., Inst. \& Exp. Tech. No. 2, 264-266 (1960).

59111 I. 0. Grishaev, B. A. Terekhov, L. K. M'yakushko \& G. L. Fursov, A titanium pump. Ukrain. Fiz. Zhur 4, 750-754 (1959).

59112 I. Kanomata, T. Oguri, Y. Kaneko \& T. Hayakawa, Mass spectrometer for static operation. Oyo Butsuri 28, 584-593 (1959).

59113 L. Pátý, Measuring of ultra high vacuum. 35 references. Pribory $i$ Tekh. Eksperimenta 6 , 3-10 (1959). Translation, Inst. Soc. Am., Inst. \& Exp. Tech. No. $\underline{6}$, 863-869 (1960).

59114 J. Pollard, Progress in vacuum technology. 95 references. Reports, Progress Phys. 22, $33-73$ (1959).

59115 K. Thiele, Electromagnetically controlled al1-glass stop-cock for very high vacuum. Vakuum-Tech. $\underline{8}, 223-226$ (1959).

59116 N. N. Axelrod, U1tra high-vacuum valve. Rev. Sci. Inst. 30, 944-945 (1959).

59117 H. L. Caswe11, Liquid helium trap for high pumping speed at low pressures. Rev. Sci. Inst. 30, 1054-1055 (1959).

59118 M. T. Dmitriev, A convection manometer. Pribory i Tekh. Eksper. No. 3, 148-149 (1959). Translation, Instruments and Exp. Tech., Inst. Soc. Am. No. 3, 495-496 (1960).

59119 I. P. S. Fish, Method for rapid determination of vacuum outgassing rates. Rev. Sci. Inst. 30, 889-890 (1959).

59120 C. M. Haaland, Metal bakeout valve for ultra high vacuum. Rev. Sci. Inst. 30, 947-948 (1959).

59121 A. Kogan, A sensitive two-liquid micromanometer. Bul1. Research Coun. Israe1 C7, No. 1, 33-36 (1959).

59122 V. Mizushima \& Z. Oda, Nonproportionality in Bayard-Alpert ionization gauge and the ultimate vacuum determination of diffusion pumps. Rev. Sci. Inst. 30, 1037-1041 (1959).

59123 I. E. Nakhut in \& E. I. Sutyagina, Absorption of hydrogen by palladium at low temperatures. Fiz. Metallov i Metallovedenie 7, 459 (1959).

59124 N. W. Robinson, A11-metal bakeable taps for high vacuum. Electronic Engg. 31, 759-760 (1959).
59125 G. Strotzer, On the electrical clean-up of gases in the high-vacuum pressure range. II. Zt. angew. Phys. 11, 223-234 (1959).

59126 R. M. Barrer \& W. I. Stuart, Ion exchange and the thermodynamics of intercrystalline sorption. I. Energetics of occlusion of argon and nitrogen by Faujasite-type crystals. II. Entropy of same. Proc. Roy. Soc., London, A249, 464-497 (1959).

59127 P. Schuerer \& L. Eckertova, Simple construction of glass titanium pump. Czech. J. Phys. , $753-754$ (1959).

$59128 \mathrm{~J}$. Yarwood, Summarized proceedings of a symposium on current developments in the production of high vacua. Brit. J. App1. Physics 10, 383-391 (1959).

59129 E. A. Ab, R. I. Plotnikov \& L. A. Khutsishvili, Sorption of hydrogen by titanium and zirconium at low pressures. Zh. Tekh. Fiz. 29, No. 9, 1146-1151 (1959).

59130 Y. I. Belyakov \& E. I. Agishev, The application of the pulse mass spectrometer to the study of gas evolution from metals. Zh. Tekh. Fiz. 29, No. 6, 796-798 (1959). Translation, Soviet Physics-Technical Physics, Am. Inst. Phys. $\underline{4}$, No. 6, 717-719 (1959).

59131 M. H. Green \& K. H. Maxwe11, Adsorption on clean germanium surfaces. J. Phys. Chem. Solids 11, 195-204 (1959).

59132 K. G. Guenther, Vacuum technology. Report on 1st Int. Cong. on Vacuum Technology, June 10-13,1959, Namur. In German. 61 references. Chem. Ing. Tech. 31, 379-387 (1959).

59133 J. W. Whee1don, Adsorption of sodium and argon by glass. Brit. J. App1. Phys. 10, 295-298 (1959).

59134 A. J. Ahearn, Mass spectrographic studies of impurities on surfaces. Trans. 6th Nat1. Symp. on Vacuum Tech., Am. Vacuum Soc. (1959) 1-5. (Pergamon Press, New York, 1960).

59135 S. P. Wolsky \& E. J. Zdanuk, The vacuum microbalance and omegatron spectrometer: study of the interaction of oxygen and clean germanium surfaces. 18 references. Trans. 6 th Nat1. Symp, on Vacuum Tech., Am. Vacuum Soc. (1959) 6-11. (Pergamon Press, New York, 1960).

59136 P. A. Redhead, The desorption spectrometer as an analytic tool in ultra-high-vacuum investigations. Trans. 6th Nat1. Symp. on Vacuum Tech., Am. Vacuum Soc. (1959) 12-15. (Pergamon Press, New York, 1960).

59137 G. E. Moore, The ionization of adsorbed gas by impact of slow electrons. Trans. 6th Nat1. Symp. on Vacuum Tech., Am. Vacuum Soc. (1959) 16-19. (Pergamon Press, New York, 1960). 
59138 R. E. Honig, U1tramigh vacuum studies with a small bakeable mass spectrometer. Trans. 6 th Nat1. Symp. on Vacuum Tech., Am. Vacuum Soc. (1959) 20-26. (Pergamon Press, New York, 1960).

59139 A. Klopfer, S. Garbe \& W. Schmidt, Residual gases in vacuum systems. Trans. 6th Nat1. Symp. on Vacuum Tech., Am. Vacuum Soc. (1959) 27-33. (Pergamon Press, New York, 1960).

59140 D. Charles \& R. J. Warnecke, Jr., Experimental study of a omegatron type mass spectrometer. Trans. 6th Nat1. Symp. on Vacuum Tech., Am. Vacuum Soc. (1959) 34-41. (Pergamon Press, New York, 1960).

59141 I. Farkass \& G. F. Vanderschmidt, The production of ultra-high vacuum in metal systems larger than one thousand 1iters. 16 references. Trans. 6th Nat1. Symp. on Vacuum Tech., Am. Vacuum Soc. (1959) 42-47. (Pergamon Press, New York, 1960).

59142 J. C. Simons, Jr., An ultra-high vacuum chamber for space simulation. Trans. 6th Nat1. Symp. on Vacuum Tech., Am. Vacuum Soc. (1959) 48-54. (Pergamon Press, New York, 1960).

59143 M. Rivera \& R. Le Riche, A differential1y pumped ultra-high vacuum system. Trans. 6th Nat1. Symp. on Vacuum Tech., Am. Vacuum Soc. (1959) 55-59. (Pergamon Press, New York, 1960).

$59144 \mathrm{H}$. Schwarz, U1tra-high vacuum pumping by vibrating membrane. Trans. 6th Nat1. Symp. on Vacuum Tech., Am. Vacuum Soc. (1959) 6065. (Pergamon Press, New York, 1960).

59145 H. L. Caswe11, An oil-free u1tra-high vacuum system for the deposition of thin films. Trans. 6th Nat1. Symp. on Vacuum Tech., Am. Vacuum Soc. (1959) 66-71. (Pergamon Press, New York, 1960).

59146 H. G. Noe1ler, G. Reich \& W. Baechler, Diffusion pump and baffle system of large suction speeds for pressures lower than 10-8 Torr. Trans. 6th Nat1. Symp. on Vacuum Tech., Am. Vacuum Soc. (1959) 72-74. (Pergamon Press, New York, 1960).

59147 N. A. Florescu, New method for vacuum measurements in the molecular range of pressures. Trans. 6th Nat1. Symp. on Vacuum Tech., Am. Vacuum Soc. (1959) 75-81. (Pergamon Press, New York, 1960).

59148 J. R. Roehrig \& G. F. Vanderschmidt,Advances in the design of vacuum gauges using radioactive materia1s. Trans. 6th Nat1. Symp. on Vacuum Tech., Am. Vacuum Soc. (1959) 82-84. (Pergamon Press, New York, 1960).

$59149 \mathrm{R}$. L. Ramey, The theory and design of subminiature ionization gauge tubes. Trans. 6 th Nat1. Symp. on Vacuum Tech., Am. Vacuum Soc. (1959) 85-88. (Pergamon Press, New York, 1960).
59150 P. L. Vitkus, A multi-point vacuum measuring system for low pressure wind tunnels. Trans. 6 th Nat1. Symp. on Vacuum Tech., Am. Vacuum Soc. (1959) 89-93. (Pergamon Press, New York, 1960).

59151 J. L. Peters, An ultra-sensitive mass spectrometer leak detector and its application to vacuum technology. Trans. 6th Nat1. Symp. on Vacuum Tech., Am. Vacuum Soc. (1959) 94-96. (Pergamon Press, New York, 1960).

59152 C. B. Bickne11, An improved helium-only sensitive method for calibrating silica membrane helium leaks. Trans. 6th Nat1. Symp. on Vacuum Tech., Am. Vacuum Soc. (1959) 97-100. (Pergamon Press, New York, 1960).

59153 B. B. Dayton, Relations between size of vacuum chamber, outgassing rate, and required pumping speed. 45 references. Trans. 6 th Nat1. Symp. on Vacuum Tech., Am. Vacuum Soc. (1959) 101-119. (Pergamon Press, New York, 1960).

59154 D. J. Santeler, Pressure simulation of outer space. Trans. 6th Nat1. Symp. on Vacuum Tech., Am. Vacuum Soc. (1959) 129-133. (Pergamon Press, New York, 1960).

59155 D. L. Stevenson, A new type of boiler that permits improvements in the performance of oil diffusion pumps. Trans. 6th Nat1. Symp. on Vacuum Tech., Am. Vacuum Soc. (1959) 134139. (Pergamon Press, New York, 1960).

59156 H. R. Smith, Relationship of diffusion pump performance to the thermodynamics of the pumping fluid, Trans. 6th Nat1. Symp. on Vacuum Tech., Am. Vacuum Soc. (1959) 140145. (Pergamon Press, New York, 1960).

59157 ฟ. K. Huber \& E. A. Trendelenburg, Recent developments of ultra-high vacuum systems using oil diffusion pumps. Trans. 6th Nat1. Symp, on Vacuum Tech., Am. Vacuum Soc.(1959) 146-149. (Pergamon Press, New York, 1960).

59158 W. G. Henderson, J. T. Mark \& C. S. Geiger, Evaluation of large diffusion pumps and traps for the ultra-high vacuum system of the Mode1 C-Stellarator. Trans. 6th Nat1. Symp. on Vacuum Tech., Am. Vacuum Soc. (1959) 170-175. (Pergamon Press, New York, 1960).

59159 G. E. Becker, Adsorption of gases on mercury at $77^{\circ} \mathrm{K}$. Trans, 6th Nat1. Symp. on Vacuum Tech., Am. Vacuum Soc. (1959) 197-203. (Pergamon Press, New York, 1960).

$59160 \mathrm{~T}$. Kraus, On the use of the pumping time equation in the vacuum technique. Trans. 6 th Nat1. Symp. on Vacuum Tech., Am. Vacuum Soc. (1959) 204-205. (Pergamon Press, New York, 1960). 
59161 S. R. Mielczarek, D. C. Schubert \& L. Marton, Apparatus for electron optical study of lowdensity gas flow. Trans. 6th Nat1. Symp. on Vacuum Tech., Am. Vacuum Soc. (1959) 206209. (Pergamon Press, New York, 1960).

59162 F. R. Gleason, J. H. Greiner \& L. R. Yetter, Gas absorption by vacuum evaporated magnetic films. Trans. 6th Nat1. Symp. on Vacuum Tech., Am. Vacuum Soc. (1959) 223-227. (Pergamon Press, New York, 1960).

59163 K. H. Behrndt, A demountable ultra-high vacuum glass system and its components. 28 references. Trans. 6th Nat1. Symp. on Vacuum Tech., Am. Vacuum Soc. (1959) 255-260. (Pergamon Press, New York, 1960).

59164 H. Ehlers \& J. Mo11, Results with u1trahigh vacuum metal system including windows, evaporators and lead-ins. Trans. 6th Nat1. Symp. on Vacuum Tech., Am. Vacuum Soc. (1959) 261-264. (Pergamon Press, New York, 1960).

59165 T. H. Batzer, A large bakeable vacuum valve. Trans. 6th Nat1. Symp. on Vacuum Tech., Am. Vacuum Soc. (1959) 265-267. (Pergamon Press, New York, 1960).

59166 H. R. Smith \& P. B. Kennedy, U1tra-1ow temperature mechanical refrigeration systems for high-vacuum traps and baffles. Trans. 6 th Nat1. Symp. on Vacuum Tech., Am. Vacuum Soc. (1959) 271-277. (Pergamon Press, New York, 1960).

59167 J. A. Zo11man, I. E. Martin \& J. A. Powe11, Ceramic, sapphire and glass seals for the mode1 C-ste11arator. Trans. 6th Nat1. Symp. on Vacuum Tech., Am. Vacuum Soc. (1959) 278282. (Pergamon Press, New York, 1960).

59168 F. A. Loughridge \& W. S. Wong, Improved reliability of soft glass to metal vacuum tight seals. Trans. 6th Nat1. Symp. on Vacuum Tech., Am. Vacuum Soc. (1959) 283287. (Pergamon Press, New York, 1960).

$59169 \mathrm{~J}$. Morrison, The behavior of titanium in a high vacuum. Trans. 6th Nat1. Symp. on Vacuum Tech., Am. Vacuum Soc. (1959) 291296. (Pergamon Press, New York, 1960).

59170 A. K1opfer \& W. Ermrich, Properties of a sma11 titanium-ion pump. Trans. 6th Nat1. Symp. on Vacuum Tech., Am. Vacuum Soc. (1959) 297-301. (Pergamon Press, New York, 1960).

59171 W. M. Brubaker, A method for greatiy enhancing the pumping action of a Penning discharge. Trans. 6th Nat1. Symp. on Vacuum Tech., Am. Vacuum Soc. (1959) 302-306. (Pergamon Press, New York, 1960).

59172 R. Zaphiropoulos \& W. A. Lloyd, Design considerations for high speed getter-ion pumps. Trans. 6th Nat1. Symp. on Vacuum Tech., Am. Vacuum Soc. (1959) 307-310. (Pergamon Press, New York, 1960).
59173 I. Ames \& R. L. Christensen, Some studies of getter-ion pumped vacuum systems. 19 references. Trans. 6th Nat1. Symp. on Vacuum Tech., Am. Vacuum Soc. (1959) 311-316. (Pergamon Press, New York, 1960).

59174 P. de11a Porta, Recent information on the gettering of gases by barium films. Trans. 6 th Nat1. Symp. on Vacuum Tech., Am. Vacuum Soc. (1959) 317-324. (Pergamon Press, New York, 1960).

59175 S. P. Wolsky, Studies of semiconductor materials using vacuum microbalance. Semiconductor Products 2, 36-41 (1959).

59176 G. Ehrlich, Molecular processes at the gassolid interface. 160 references. Proceedings, Int. Conf. on Structure and Properties of Thin Films, Bolton Landing, N. Y. (Sept. 1959) 423-475. (Wiley \& Sons, 1959).

59177 G. Thuronyi, Selected annotated bibliography on propagation of acoustic and exp1osion waves in the atmosphere. 122 references. Meteorological Abstracts and Bibliography, Am. Meteoro. Soc. 10, 1072-1098 (1959).

59178 T. Punter, Methods of cleaning glass by vapour degreasing and ultrasonically agitated solvents. Brit. J. App1. Phys. 10, 332-336 (1959) .

6001 C. Y. Bartholomew \& A. R. LaPadula, Penetram tion depth investigation of gas cleanup with radioactive tracers. J. App1. Phys. 31, 445 (1960).

6002 T. W. Hickmott, Interaction of atomic hydra gen with glass. J. App1. Phys. 31, 128-136 (1960).

6003 C. C. Leiby, Jr. \& C. L. Chen, Diffusion coefficients, solubilities, and permeabilities for $\mathrm{He}, \mathrm{Ne}, \mathrm{H}_{2}$, and $\mathrm{N}_{2}$ in vycor glass. J. App1. Phys. 31, 268-274 (1960).

6004 B. J. Todd, J. L. Lineweaver \& J. T. Kerr, Outgassing caused by electron bombardment of glass. J. App1. Phys. 31, 51-55 (1960).

6005 H. D. Hagstrum \& C. D'Amico, Production and demonstration of atomica11y clean metal surfaces. J. App1. Phys. 31, 715-723 (1960).

6006 P. della Porta \& F. Ricca, The gettering of carbon monoxide by barium films. 77 refer ences. Le Vide 15, 3-27 (1960).

6007 M. Warnecke \& P. C. Moutou, on a miniature t1tanium pump. Le vide 15, 41-51 (1960).

6008 H. H. Reamer \& B. H. Sage, High pressure manometer. Rev. Sci. Inst. 31, 337-341 (1960). 
6009 h. G. Brombacher, D. P. Johnson \& J. L. Cross, Mercury barometers and manometers. NBS Monograph No. 8, 59 p. (1960).

6010 J. M. Anderson, Thin vacuum-tight mica window suitable for baking at $500^{\circ} \mathrm{C}$. Rev. Sci. Inst. 31, 898-899 (1960).

6011 L. A. Harris, Trapping with alumina in vacuum systems and its effect on cathode activity. Rev. Sci. Inst. 31, 903-904 (1960).

6012 G. Thomaes \& R. Van Steenwinke1, Measurement of small differences in the second virial coefficient of gases below $0^{\circ} \mathrm{C}$. Rev. Sci. Inst. 31, 825-827 (1960).

6013 N. A. F1orescu, On the conductance of systems for molecular flow of gases. 12 references. Le Vide 15, 197-209 (1960).

$6014 \mathrm{~J}$. Herbert, New applications of glass in electronics. Le Vide 15, 268-285 (1960).

6015 W. Huber \& E. A. Trendelenburg, Recent developments of ultra-high vacuum systems using oil diffusion pumps. Le Vide 15, 132139 (1960).

6016 J. Pierre, Calibration systems in vacuum technique. Le Vide 15, 210-219 (1960).

6017 R. Rocherolles, Pumping of tubes on a double pumping unit. Le Vide 15, 112-119 (1960).

6018 W. Dah1ke \& H. J. Schuetze, Residual gas pressure in electron tubes. Method of meas urement. Vacuum 10, 3-4 (1960).

6019 H. J. Schuetze \& H. W. Eh1beck, Residual gas in electron tubes. Experimental results. Vacuum 10, 5-6 (1960).

6020 A. Klopfer, S. Garbe \& W. Schmidt, Residual gases in vacuum systems. Vacuum 10, 7-12 (1960).

6021 S. P. Wo1sky \& E. J. Zdanuk, The investigation of residual gases in vacuum systems. Vacuum 10, 13-21 (1960).

6022 J. C. Franken \& J. Van Der Waa1, Residua1 gases in picture tubes. Vacuum 10,22-26 (1960).

6023 R. H. Collins \& J. C. Turnbu11, Evolution and absorption of gases in electron tubes. Vacuum 10, 27-30 (1960).

6024 W. Tretner, An electrostatic mass spectroscope. Vacuum 10, 31-34 (1960).

6025 G. Reich \& F. Flecken, Analys is of partial pressures by means of omegatron and farvitron. Comparative view of the ranges of application. Vacuum 10, 35-39 (1960).

6026 J. P. Freytag, Use of a test diode as a means of controlling the materials of construction of electronic tubes. In French. 25 references. Vacuum 10, 40-48 (1960).
6027 R. J. Warnecke, Jr., Application of mass spectrometers in electron tube technology. In French. Vacuum 10, 49-57 (1960).

6028 F. A. Baker \& T. A. Giorgi, The applicability of the omegatron to continuous analys is of residual gases. Vacuum 10, 58-63 (1960).

6029 G. Calvi, Double Pirani bridge leak detector. Vacuum 10, 64-67 (1960).

6030 A. Nasini, F. Ricca \& G. Saini, Clean surfaces and sorption of gases. 29 references. Vacuum 10, 68-74 (1960).

6031 N. W. Robinson, The action of molybdenum, tungsten, tantalum and nicke 1 on residual gases in a vacuum system. Vacuum 10, 7580 (1960).

6032 S. Garbe, A. Klopfer \& W. Schmidt, Some reactions of water in electron tubes. Vacuum 10, 81-85 (1960).

6033 S. H. Cross, System design and the choice of materials for the Nimrod vacuum system. Vacuum 10, 86-91 (1960).

6034 K. Hashimoto, H. Iwayanagi \& H. Fukushima, Measurement of gas evolution and absorption from materials used in vacuum tubes. Vacuum 10, 92-99 (1960).

6035 R. W. Lawson, The influence of residual gas on the performance of the British Post office submarine telephone repeater valve type 6P12. Vacuum 10, 100-105 (1960).

6036 N. W. W. Smith, Noise reduction in microwave tubes by getter-ion pumping. Vacuum 10 , 106-109 (1960).

6037 T. H. Briggs \& S. Nadeau, Effects of continuous gas clean-up upon cathode emission and cathode interface impedance. 10 references. Vacuum 10, 112-117 (1960).

6038 R. A. Haefer, On the use of metal-oil diffusion pumps when operating with discharge tubes sensitive to hydrocarbons. 14 references. Vacuum 10, 118-120 (1960).

6039 L. Malter \& H. Mandoli, Electron tube processing with getter-ion pumps. Vacuum 10 , 121-127 (1960).

6040 A. Klopfer \& W. Ermrich, Properties of a small titanium-ion pump. Vacuum 10, 128 132 (1960).

6041 L. Holland \& A. Harte, The gas sorption characteristics of Penning pumps and titanium films. Vacuum 10, 133-140 (1960).

6042 J. Bailleul-Langlais, Barium getters in electronic receiving tubes. In French. references. Vacuum 10, 143-150 (1960).

6043 K. Hashimoto \& K. Kitagawa, Some barium getter problems on the vacuum tubes. Vacuum 10 , 156-161 (1960). 
6044 J. M. Sourdilion, Use of zirconium sintered getters. In French. Vacuum 10, 162-165 (1960).

6045 J. H. N. van Vucht, The Ceto getter--its chemical structure and hydrogen gettering properties. Vacuum 10, 170-177 (1960).

6046 S. Fukagawa, Gettering activity of $\mathrm{Zr}, \mathrm{Ti}$ and $\mathrm{Ba}$ for oxygen gas under mercury vapour. Vacuum 10, 178-180 (1960).

6047 P. de1la Porta, Apparatus and techniques for measurement of the adsorption of gases by evaporated getters. 14 references. Vacuum 10, 181-187 (1960).

6048 M. G. Char1ton, D. Newson \& P. J. Whitchurch An automatic apparatus for the testing of getter adsorption. Vacuum 10, 189-193 (1960).

6049 P. de1la Porta, S. Origlio \& E. Argano, The influence of ionizing currents and hot filaments on the gas adsorption by barium films. 13 references. Vacuum 10, 194-198 (1960).

6050 J. J. B. Fransen \& H. J. R. Perdijk, The absorption of gases by barium getter films applied as a too1. Vacuum 10,199-203 (1960).

6051 H. J. R. Perdijk, Structure of barium getter films. Vacuum 10, 204-209 (1960).

6052 K. M. Yazawa, Study of the surface structure of barium getter deposited film by an electron microscope. Vacuum 10, 210-211 (1960).

6053 M. G. Char1ton \& F. H. Southam, The adsorption of methane by barium films in the presence of a thermionic current. Vacuum 10, 212-214 (1960).

6054 F. Ricca \& P. de11a Porta, Carbon monoxide sorption by barium films. 26 references. Vacuum 10, 215-222 (1960).

6055 P. de11a Porta \& E. Argano, Nitrogen sorption by barium films. Vacuum 10, 223-226 (1960).

6056 P. de1la Porta \& S. Orig1io, Hydrogen sorption by barium films. Vacuum 10, 227-230 (1960).

6057 J. Hejzlar \& V. Horāček, Selective getters. 8 references. Vacuum 10, 231-233 (1960).

6058 S. JeriC \& E. Kansky, A method of measuring of caesium vapour pressure in photoelectric tubes. Vacuum 10, 234-239 (1960).

6059 E. Kanksky \& S. Jeric, Some results of the measurement of caesium vapour pressure in photoelectric tubes during their manufacture and 1ife. Vacuum 10, 240-244 (1960).
6060 N. A. Florescu, The theoretical development of the vapour vacuum pump. Vacuum 10, 250259 (1960).

6061 R. N. Bloomer, On the general principles of chemical and ionic pumping. 20 references. Vacuum 10, 260-262 (1960).

6062 H. Batey, Carbon contamination of glassware used for vacuum purposes. Vacuum 10, 263265 (1960).

6063 L. E11sworth, Calibration factors of ionization gauges for hydrocarbon gas mixtures. Vacuum 10, 266-267 (1960).

6064 G. Hinzpeter, A hot cathode ionization gage for measuring pressures to 10-1 Torr. In German. Experimente1le Tech. Phys. 8, 8995 (1960).

6065 R. Gilmont, Improved McLeod gage. Inst. and Contro1 Systems 33, 1350-1351 (1960).

6066 H. L. Eschbach \& R. Jaecke1, Enamelled walls for ultra high vacuum containers. In German. Zt. Naturforsch. 15a, 268-269 (1960).

6067 T. \& A. Roth, Nomographic design of vacuum installations. Brit. Chem. Eng. 5 , 392400 (1960).

6068 J. Siedlewski \& K. Karpinski, Adsorption methods of determining the surface area of adsorbents and catalysts. 45 references. Wiadomości Chemi. 14, 279-294 (1960).

6069 L. A. Camby \& C. J. Milner, Sensitivity of the omegatron. Rev. Sci. Inst. 31,776 (1960).

6070 G. Barnes, New type of cold cathode vacuum gauge for the measurement of pressures below $10^{-3} \mathrm{~mm} \mathrm{Hg}$. Rev. Sci. Inst. 31, 608611 (1960).

6071 F. A. Baker, Nonproportionality in the Bayard-Alpert ionization gauge. Rev. Sci. Inst. 31, 911 (1960).

6072 N. A. Florescu, Design of glass oil-vapour vacuum pumps. Lab.Practice 9, 33-34 (1960).

6073 R. H. Gooda11, Transparent electroconductive coatings on lead glass. Rev. Sci. Inst. 31, 344-345 (1960).

6074 B. Gorowitz, K. Moses \& P. Gloersen, Magnetically driven fast-acting valve for gas injection into high vacua. Rev. Sci. Inst. 31, 146-148 (1960).

6075 N. R. Daly, High sensitivity mass spectrometer leak detector. Rev. Sci. Inst. 31, 720-723 (1960).

6076 0. M. Katz \& E. A. Gulbransen, Permeability and diffusivity of hydrogen through a palladium tube. Rev. Sci. Inst. 31,615-617 (1960). 
6077 Westinghouse Mfg. Co., Measurement of u1tralow pressures. Electronics 33, 106 (Nov. 11, 1960).

6078 L. R. Linner, R. I. George \& R. B. McQuistan, Automatic vacuum control in the 760 to $1 \mathrm{x}$ 10-8 Torx range. Rev. Sci. Inst. 31, 650652 (1960).

6079 P. A. Redhead, Modulated Bayard-Alpert gauge. Rev. Sci. Inst. 31, 343-344 (1960).

6080 D. E. Swets, Application of the RCA 1945 gauge to the analysis of hydrogen in metals. Rev. Sci. Inst. 31, 659 (1960).

6081 H. W. Drawin, The applicability of a capacity micromanometer as a vacuum gage. In German. $\mathrm{Zt}$. Instrumentenk. 68, 1-8 (1960).

6082 D. D. Eley \& P. R. Wilkinson, Adsorption and oxide formation on aluminum films. Proc. Roy. Soc., London, A254, 327-342 (1960).

6083 T. W. Hickmott, Interaction of hydrogen with tungsten. J. Chem. Phys. 32, 810-823 (1960).

6084 W. S. Kreisman, Methods of using a McLeod gauge to measure higher pressures. Rev. Sci. Inst. 31, 782-784 (1960).

6085 L. A. Noble, พ. H. Sain \& R. K. Waits, Compact palladium diffusion leak for hydrogen. Rev. Sci. Inst. 31, 789-790 (1960).

6086 L. Pátý, An experimental equipment for obtaining very low pressures. In Czech. Slaboproudy Obzor 21, 106-109 (1960).

6087 H. Schwarz, Forced periodic changes of kinetic energy of gas molecules as a means of vacuum measurement. Rev. Sci. Inst. 31, 433-439 (1960).

6088 P. Weulersse, M. Balkanski \& P. Aigrain, Study of chemisorption and photodesorption on oxidized titanium. In French. Compte Rend. Acad. Sci. 250, 1246-1248 (1960).

6089 Y. I. Belyakov \& N. I. Ionov, Pulsed massspectrograph investigation of desorption of hydrogen and deuterium from palladium. $\mathrm{Zh}$. Tekh. Fiz. 30, No. 2, 216-222 (1960). Translation, Soviet Physics, Technical Physics, Am. Inst. Physics, $\underline{5}$ No. 2, 195-200 (1960).

6090 K. B. Blodgett \& T. A. Vanderslice, Mechanism of inert gas cleanup in a gaseous discharge. J. App1. Phys. 31, 1017-1023 (1960).

6091 R. K. Burshtein, L. A. Larin \& G. F.Voronina, Chemisorption of oxygen on germanium. Dok1. Akad. Nauk. SSSR 130, No. 4, 801-803 (1960).

6092 K. W. T. Elliott, D. C. Wilson, F. C. P. Mason \& P. H. Bigg, Primary standard barometer of range 0 to $1200 \mathrm{mb}$. J. Sci. Inst. 37, 162-166 (1960).
6093 M. Green \& K. H. Maxwe11, The adsorption of oxygen on clean silicon surfaces. J. Phys. Chem. Solids 13, 145-150 (1960).

6094 F. A. Lewis \& W. H. Schurter, Absorption of hydrogen by palladium-silver alloys. Naturwissenschaften $47,177-178$ (1960).

6095 W. McGowan \& L. Kerwin, Some sensitivities of ion gauges. Can. J. Phys. 38, 567-569 (1960).

6096 L. Pátý, Pumping effect of a gas discharge high-vacuum pump. Nature 185, 674-675(1960).

6097 J. F. Sayers, Epoxy-resin joints for sealedoff high vacuum tubes. J. Sci. Inst. 37 , 203-205 (1960).

6098 0. Sinanoğlu \& K. S. Pitzer, Interactions between molecules adsorbed on a surface. J. Chem. Phys. 32, 1279-1288 (1960).

6099 F. G. A11en, T. M. Buck \& J. T. Law, p Layers on vacuum heated silicon. J. Appl. Phys. 31, 979-985 (1960).

60100 R. N. Bloomer \& W. C. Brooks, Simp1e detector for small leaks using a thoriated tungsten emitter with oxygen as a probe gas. J. Sci. Inst. 37, 306-307 (1960).

60101 P. Bouyer, C. Cassigno1 \& P. Lazeyras, An a11-metal leak valve. Le Vide $15,297-300$ (1960).

60102 W. E. Danforth \& D. L. Goldwater, Density of a thorium monolayer for maximum thermionic emission. J. App1. Physics 31, 1715-1717 (1960).

60103 M. Green \& K. H. Maxwe11, Cut-off for the vacuum manipulation of chlorine. J. Sci. Inst. 37, 303-304 (1960).

60104 A. E. D. Heylen, Bakeable bellows-type differential pressure manometer. J. Sci. Inst. 37, 251-252 (1960).

$60105 \mathrm{D}$. Lichtman, Use of the omegatron in the determination of parameters affecting limiting pressures in vacuum devices. J. Appl. Phys. 31, 1213-1221 (1960).

60106 G. Mesnard \& R. Uzan, Temperature variations of oxide coated cathode produced by current flow. Le Vide 15, 301-312 (1960).

$60107 \mathrm{~J}$. Pierre, Fluid traps in vacuum technique. Le Vide 15, 313-323 (1960).

$60108 \mathrm{P}$. Cannon, The submonolayer adsorption of argon and krypton on molybdenum disulphide; phenomenological comparison with studies on graphite. J. Phys. Chem. 64, 858-861 (1960).

60109 B. H. Clampitt \& D. E. German, Adsorption on porous solids. J. Phys. Chem. 64, 284-286 (1960). 
60110 G. L. Gaines, Jr., \& P. Cannon, On the energetics of physically adsorbed films, with particular reference to the use of krypton for surface area measurement. J. Phys. Chem. 64, 997-1000 (1960).

60111 D. T. Peterson \& D. G. Westlake, Diffusion of hydrogen in thorium. J. Phys. Chem. 64, $649-651(1960)$.

60112 R. H. Mueller, Wide range electronic micromanometer useful in research laboratory. Ana1. Chem. 32, 103A-106A (Nov. 1960).

60113 G. Barnes, Erroneous readings of large magnitude in a Bayard-Alpert ionization gauge and their probable cause. 36 references. Rev. Sci. Inst. 31, 1121-1127 (1960).

60114 H. J. Bixler, A. S. Michaels \& R. B. Parker, Use of McLeod gauges at room temperature for gases with high critical temperature. Rev. Sci. Inst. 31, 1155 (1960).

60115 A. 0. Nier, Sma11 general purpose doub1e focusing mass spectrometer. 27 references. Rev. Sci. Inst. 31, 1127-1132 (1960).

$60116 \mathrm{~K}$. Hickman, Pump fluids for higher vacuums. Nature 187, 405-406 (1960).

60117 R. Schneiderreit, A vacuum gage for normal pressure to high vacuum in one range with continuous indication. In German. VakuumTech. 9, 128-130 (1960).

60118 A. P. Flanick \& J. A insworth, A thermistor pressure gauge. Nat1. Aero. Space Adm. Technical Note D-504, 13 p. (1960).

60119 h. G. Van Dorn, A 1ow frequency microbarograph. J. Geophys. Res. 65, 3693-3698(1960).

60120 M. W. Roberts, High vacuum techniques. 44 references. J. Roy. Inst. Chem. 84, 275282 (1960).

60121 W. B. Nottingham \& F. L. Torney, Jr., A detailed examination of the principles of ion gauge calibration. MIT Research Lab. of Electronics Tech. Report 379, 10 p. (1960).

60122 L. H. Germer \& C. D. Hartman, Oxygen on nicke1. J. App1. Phys. 31, 2085-2095 (1960).

60123 J. R. Friend1y, Jr., Integration of current through getter-ion pumps. Rev. Sci. Inst. 31, $1350(1960)$.

60124 S. Leefe \& M. Liebson, Leveling system for 1iquid nitrogen. Rev. Sci. Inst. 31, 13531354 (1960).

60125 C. F. Robinson, Mass spectrometry, p. 463544 , in Physical methods in chemical analysis, edited by $\hbar$. J. Ber $1,2 d$ rev. edition, V1, Academic Press (1960).

60126 N. A. Florescu, Improvement in operation with McLeod gauge. Vacuum 10, 329-330 (1960).
60127 K. G. Guenther, A partial pressure gauge working according to the principle of the electrical mass filter. Vacuum 10, 293-309 (1960).

60128 R. Hawley, Vacuum as an insulator. 85 references. Vacuum 10, 310-318 (1960).

60129 G. Horikoshi \& A. Miyahara, High speed ionization gauge. J. Vacuum Soc., Japan 3 , 1318 (1960).

60130 R. 0. Jenkins \& W. G. Trodden, Physica1 processes in sma11 titanium ion pumps. Vacuum 10, 319-328 (1960).

60131 K. Kawasaki, T. Sugita, et a1, An ultrahigh vacuum mass spectrometer. J. Vacuum Soc., Japan 3, 96-103 (1960).

60132 P. Schwerdtfeger, A tetrode ionization gauge. Vacuum 10, 330-331 (1960).

60133 F. A. Baker \& T. A. Giorgi, Sorption and desorption in a hot-cathode ionization gage. Brit. J. App1. Phys. 11, 433-436 (1960).

60134 L. Ho1land \& L. Laurenson, Pumping characteristics of a titanium droplet getter-ion pump. Brit. J. App1. Phys. 11, 401-407 (1960).

60135 H. J. Bomelburg, Miniature hot wire pressure gages for wind tunnel work. Ballistic Res. Labs., Aberdeen Proving Ground, BRL Report No. 1095, 25 p. (1960).

60136 W. S. Kreisman, A high vacuum gauge calibration system. Geophysics Corp. of Am. Tech. Report 60-2, 26 p. (1960). Nat1. Aero. Space Adm. Contract NAS 5-270.

60137 H. R. Pass, A semi-automatic McLeod gauge. Univ. So. Calif., Engineering Center, USCEC Report No. 56-211, 36 p. (1960).

60138 L. H. Rovner, U1tra-high vacuum physics. Measurement of low pressures of oxygen. Corne11 Univ., Dept. Engineering Phys. Xerox Tech. Reprt No. 3, 34 p. (1960). Contract Nonr -401 (31).

60139 A. Klopfer \& W. Schmidt, An omegatron mass spectrometer and its characteristics. Vacuum 10, 363-372 (1960).

60140 I. Morita, F. Kanematsu \& S. Mito, Experiments on a simple getter-ion pump. J. Vacuum Soc., Japan 3, 263-268 (1960).

60141 H. H. Podgurski \& F. N. Davis, A precision McLeod gage for volumetric gas measurement. Vacuum 10, 377-381 (1960).

60142 G. Schuchhardt, Ion movements in an omegatron. Vacuum 10, 373-376 (1960).

60143 E. J. Zdanuk, R. Bierig, L. G. Rubin \& S. P. Wolsky, An omegatron spectrometer, its characteristics and application. Vacuum 10, 382-389 (1960). 

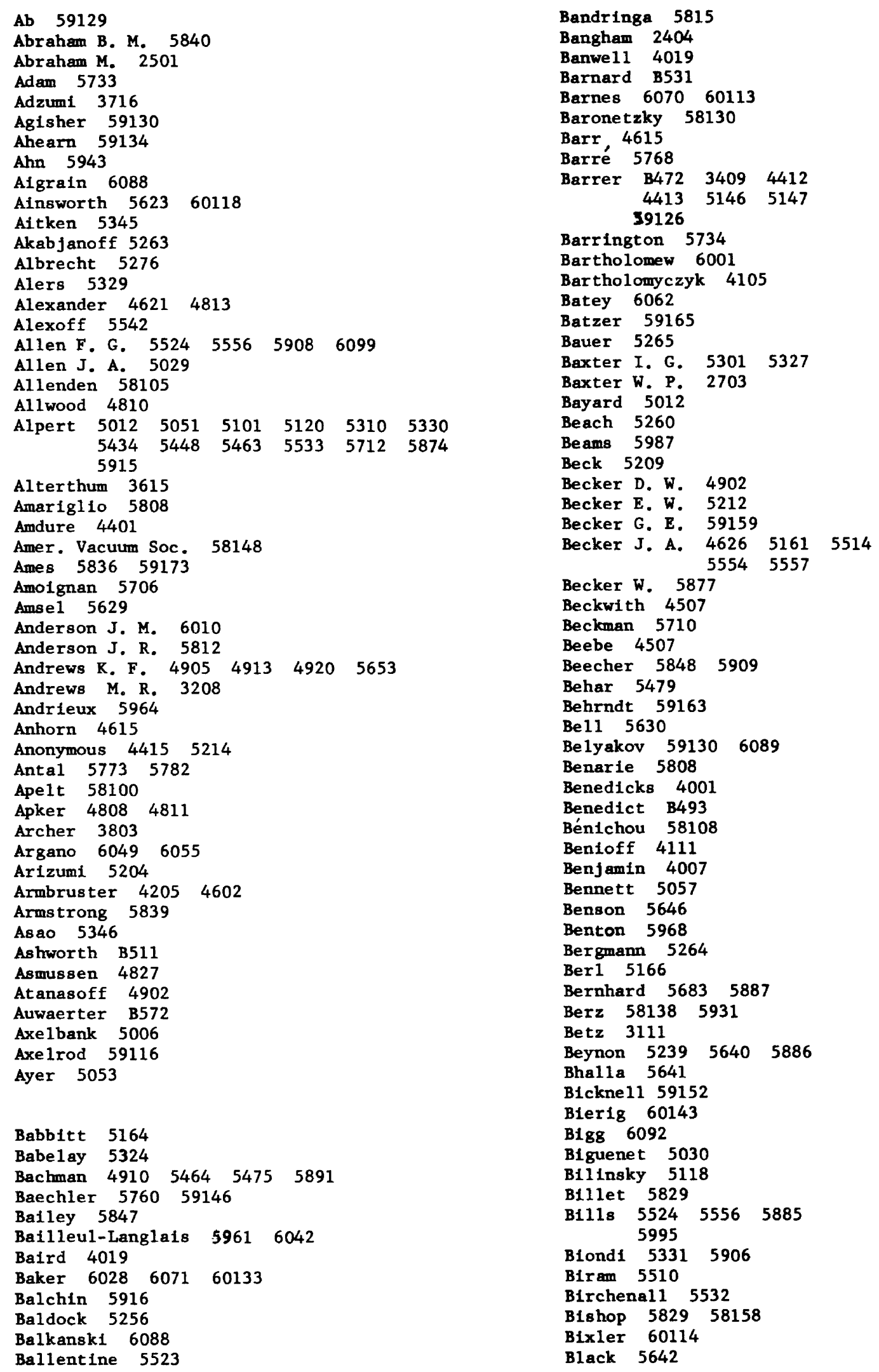


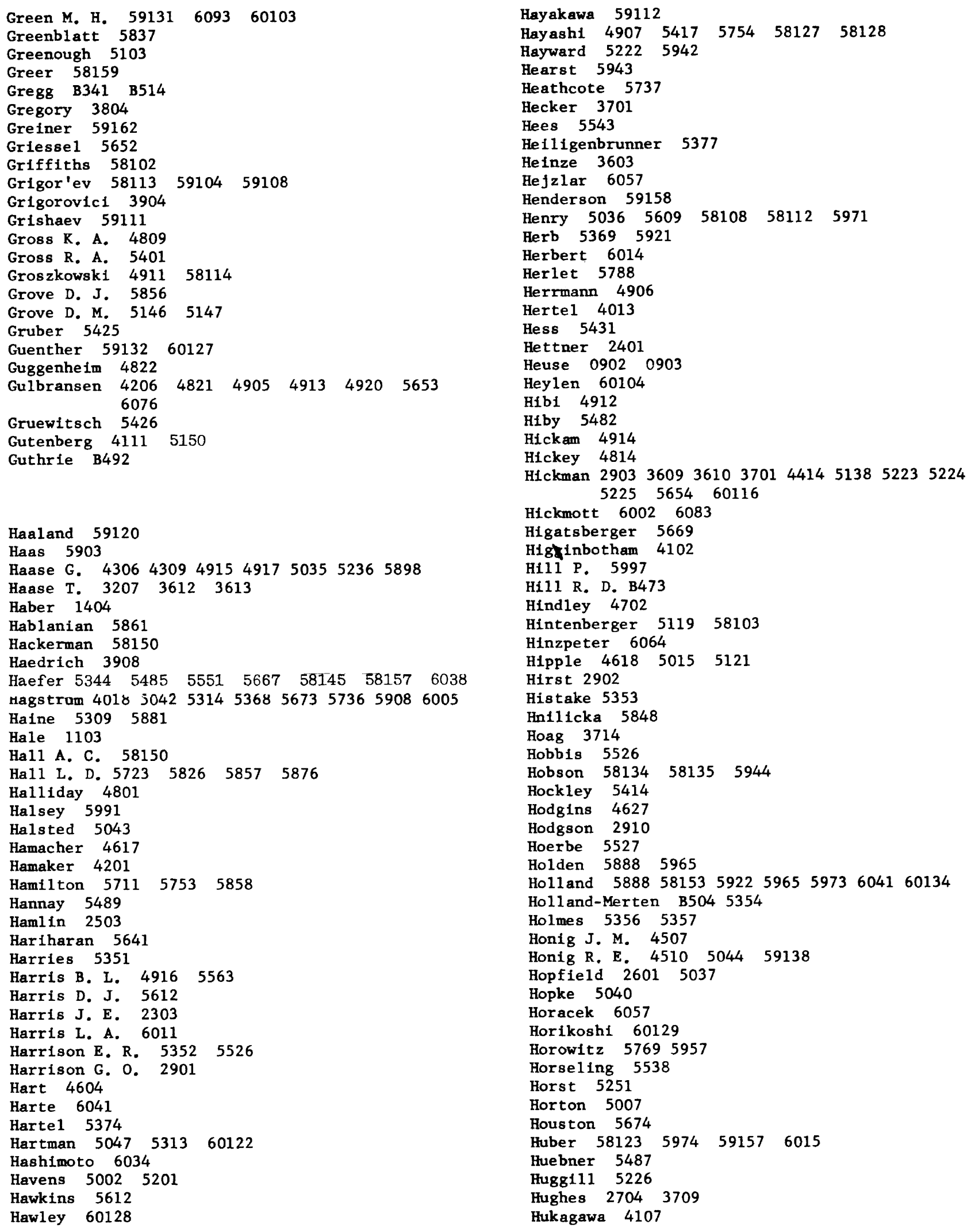


AUTHOR INDEX

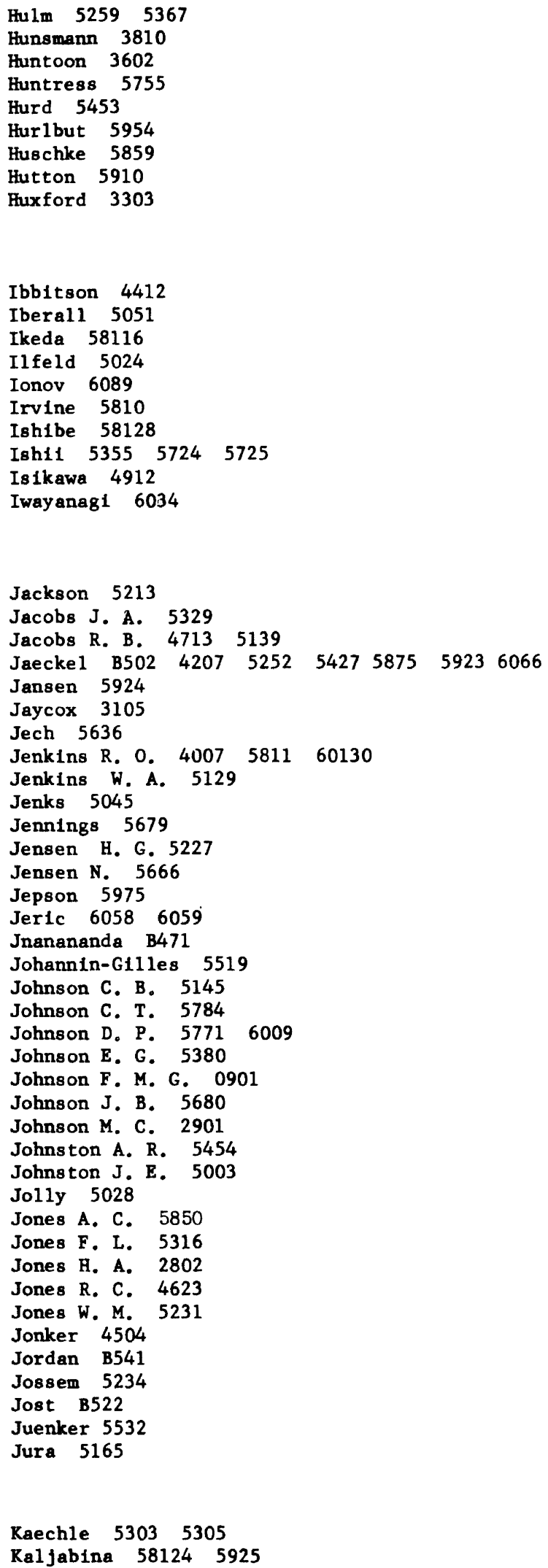

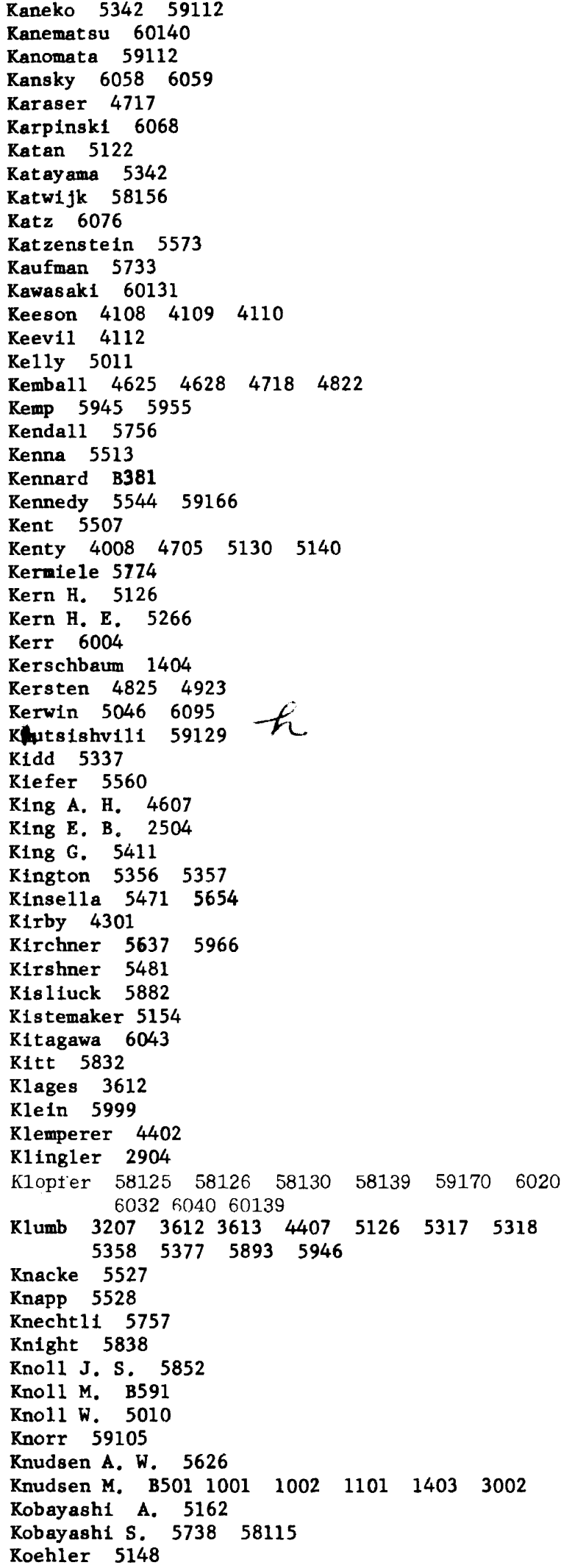


AUTHOR INDEX

Koenig 531557735782

Kogan 59121

Ko11 50025201

Kollmansperger 5318

Romiya 58116

Kondrashow 59101

Kornfeld 2904

Kotani 5204

Kramer 5841

Kratz 2907

Kraus 5860594759160

Kreisman 608460136

Krieg 4906

Kucherov 59110

Kuhn 4601

Kumagai 52375812758128

Kunz 13506

Kuper 34073714

Kutscher 5427

Kut schke 5739

Labeyrie 5111

Lacher 3715

LaGow 50025201562357695957

Laidler 4014

Lampson 3707

Landecker 5444

Lander 50135260

Landfors 5861

Landsberg 5545

Lane 4606

Lange 571258335904

Langmuir $1301 \quad 1302,130414011501150218021907$ 280233074015

Langsdorf 5460

LaPadula 6001

Larin 6091

Lashof 5540

Latham 51235228

Laurenson 5888597360134

Lavender 4805

Law 5632590859486099

Lawrance 5472

Lawrence E. O. 52195333

Lawrence J. B. 5229

Lawrenson 5965

Lawson 6035

Lawton 4009

Lawyer 5751

Lazarev 5976

Lazeyras 60101

LeBlanc J. A. 5655

LeBlanc M. B512

Lech 54315543

Leck B571 5114512752025312540354325506 553956015604571358275812959102

Lederer 3708

Leduc 4908

Lee G. H. 5575

Lee R. W. 5822

Leefe 60124

Legallais 4701

Legault 4807
Leiby 6003

LeR1che 586859143

Levina 5536

Lew in 5862

Lewis 6094

Leyniers 59335986

Lichtman 60105

Liebson 60124

Lienard 5899

Liley 5733

Lilly 4701

Lind 5359

Lineweaver 6004

Linner 6078

Lintz 5983

Lipson 5458

Litting 5210

Little 5128

Littwin 2804

Litwak 5468

Livingston 4411

Lloyd W. A. 59172

Lloyd E. C. 5772

Lloyd J. T. 5025

Lockenwitz 3807

Lofgren 521852195333

Lompe 3615

Loneragen 5807

Long J. S. 2505

Long R. A. K. 5304

Longim 5141

Lorenz 58635977

Lortie 5520

Los 5104

Lott 5613

Loughridge 59168

Low 5926

Lowry H. H. 2702

Lowry R. A. 5529

Lueckert 5946

Lukirsky 3110

Lundberg 5443

Lynn 5614

Lyon D. N. 5220

Lyon K. S. B592

Lyubimov 5927

Mackay 1401

Madden 5151

Magnus 29072908

Mahoney 58144

Makinson 4826

Makower 4807

Mallard 5160

Malmberg 5329

Malter 6039

Mandoli 6039

Manley 24052701

Mann 34023702

Manov 5895

Marchais 5984

Mark J. T. 59158

Mark R. 5862 
Markal1 58131

Marker 5928

Marsha11 39064416

Marth 5728

Martin A. J. 5442

Martin C. S. 543256015713

Martin I. E. 59167

Martin J. H. 4812

Martin L. H. B473

Martin S. T. 3909

Marton B511 59161

Maslach 5230

Mason 6092

Massey B524

Matheson 48035771

Matland 50515101

Mat suda 5353

Mazumder 5992

Maxwe11 59131609360103

$\mathrm{McBa}$ in B321

McCouhrey 50515101

McCullock 5247

McDonald 5820

McFarland 5820

McGowan 6095

McIlwraith 4709

McIntosh 0901

McKee 5998

McLeod 7501

McMillan F. A. 5418

McMillan J. A. 5713

McNarry 5428

McQuistan 6078

Meakin 5152

Mears 5490

Meechan 5834

Meissner 55415656

Mellen 460846094828

Mellett 5726

Mellville B391

Melroy 5972

Melton 5777

Menshikov 593559106

Merlin 5034

Mesnard 60106

Metson 50545106

Meyer 3408

Michaels 60114

Michijima 5321

Mickelsen 5842

Mielczarek 59161

Mielenz 53195486

Mierdel 2803

Mikhnevich 57865787

Milazzo 56435677

Miller A. R. B495

Miller G. H. 53345529

Miller L. D. 5929

Milleron 575858645865

Millican 5644

Milner 491851156069

Minchen 5568

Minter 5821

Miranda 50085231

Mitchell E. W. J. 5206
Mitchel1 J. W. 5029

Mitogoad

Miyahara 60129

Mizushima 59122

Manoh

Moench B503 5232 C

Moesta 56395854

Mo11 J. 59164

Mol1 W. J. H. 4010

Moller 56625806

Molnar 5047

Mongodin 5611576857815978

Monk 4824

Monroe 5438

Montgomery 3805

Moody 5657

Moore A. R. 5163

Moore G. E. 59137

Mordike 5916

Morey B543

Morgan 5615

Morgulis 340455555914

Morita 60140

Morrison 5104532553355502575959169

Morse 4003

Moser 35075776

Moses 6074

Mott 4722

Moutou 6007

Mueller C. 2906

Mueller E. W. 360536063711371238095684

Mueller R. H. 60112

Muendel 1306

Mukherjee 59103 vel/ciz, K,

Muiftz 58101

Muramat su 5346

Murata 5484

Murmann 33043305

Murphy 5534

Musa 5746

M'yakushko 59111

Nadeau 6037

Nagaeda 5052

Nagarjunan 5989

Nakayama 57245725

Nakhut in 59123

Nambo 4107

Nash 5026

Nasini 59516030

Naval Ord. Lab. 4703

Neher 5454

Nelson H. 4505

Nelson R. B. 42024506

Nerken 5658

Nester 545556075715

Neumann K. 3210

Neumann R. 4817

Neuzilora 58154

New 3406

Newberry 3201

Newell F. B. 58143 
AUTHOR INDEX

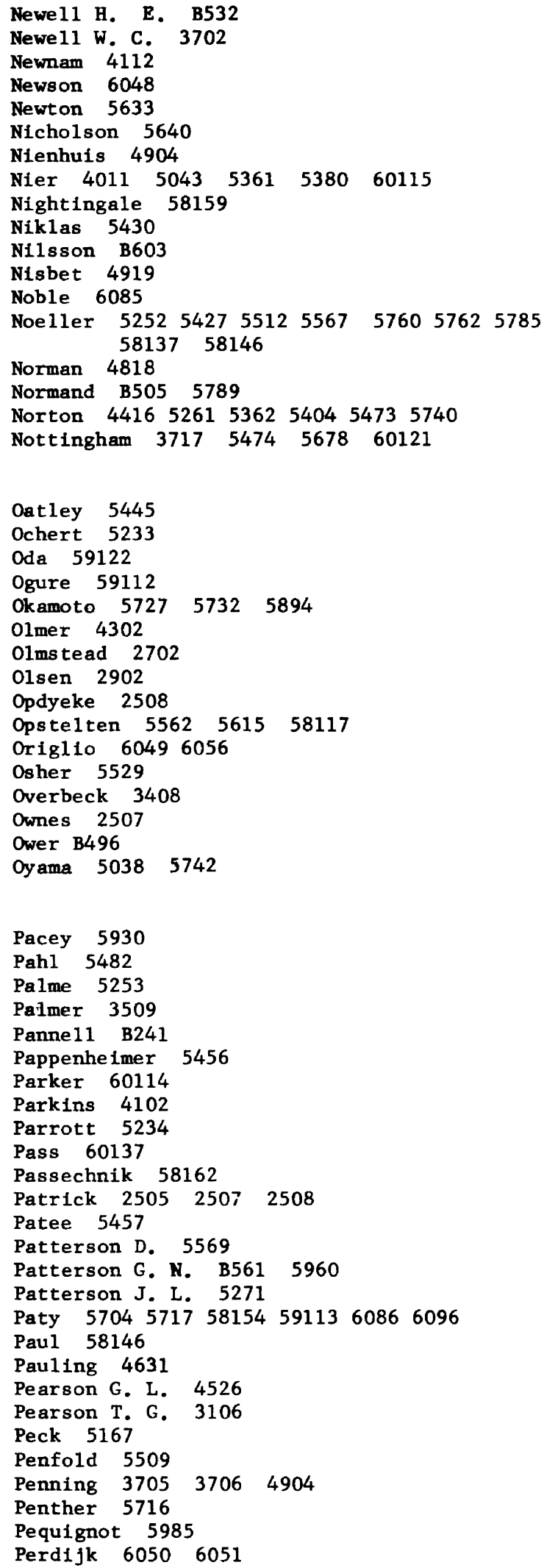

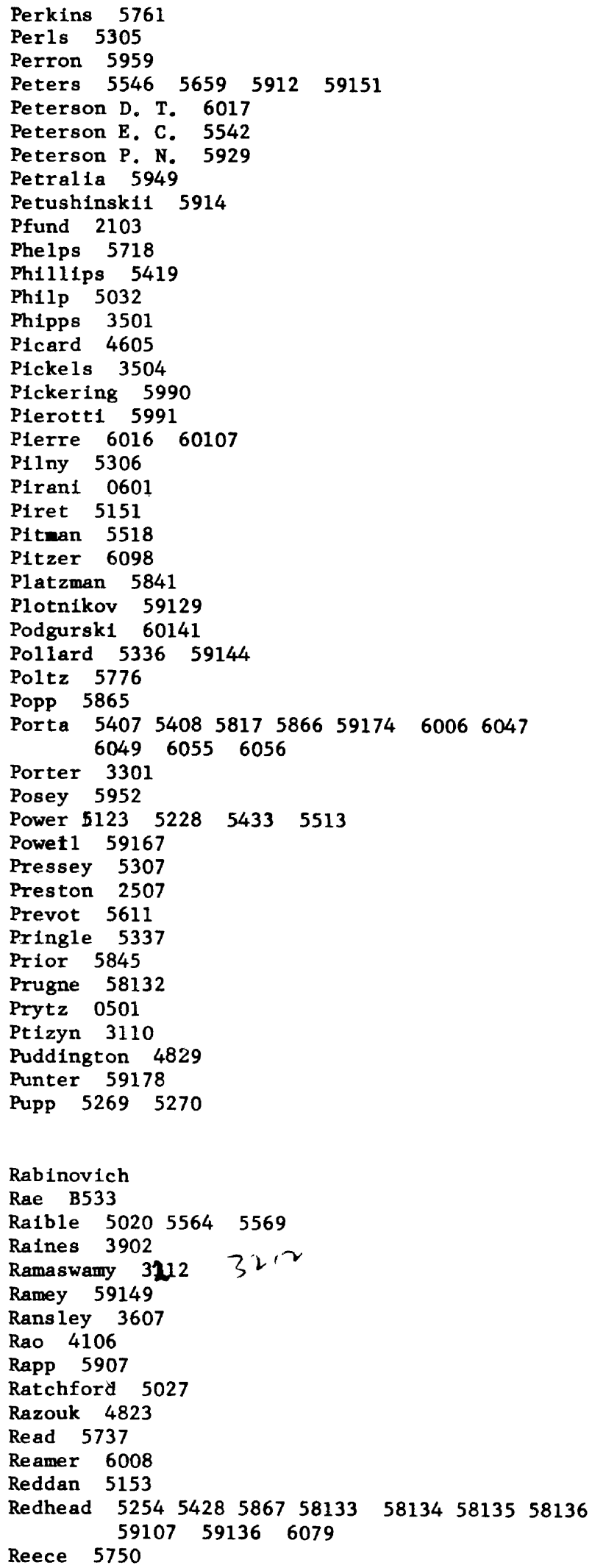


AUTHOR INDEX

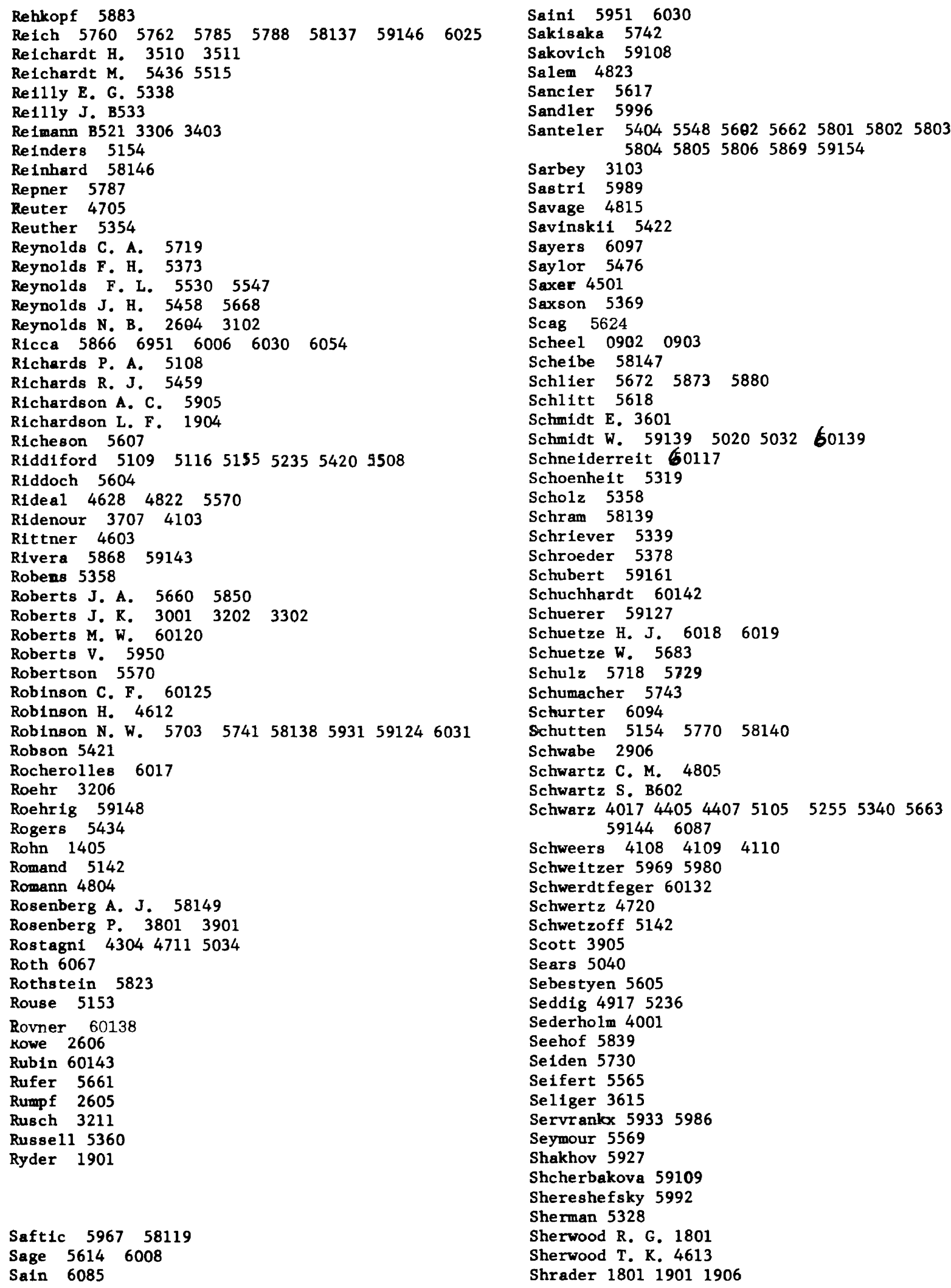


AUTHOR INDEX

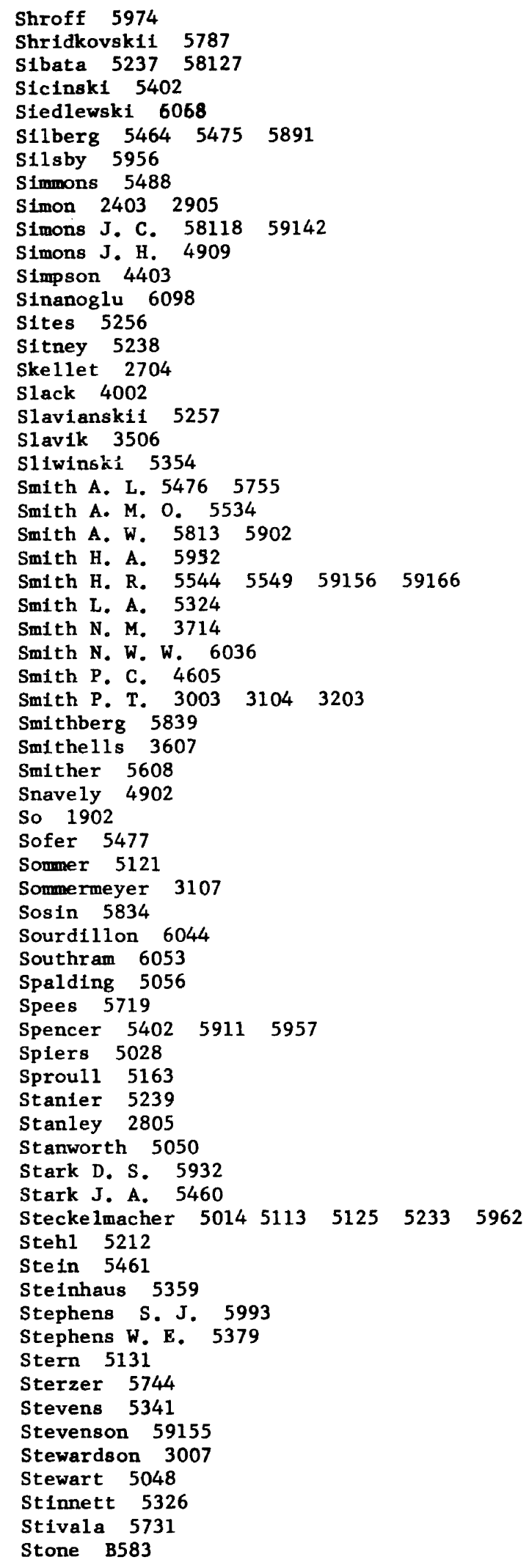




\section{AUTHOR INDEX}

Tsukakoshd $5266 \quad 5372$

Turnbull A. H. 5004

Turnbull J. C. 6023

Turner 5734

Tuth111 5108

Tuz1 $5237 \quad 5732 \quad 5894$

Tyler 5163

Umb11a 5143

Urry 5638

Utterback 3201

Uyeda 5375

Uzan 60106

Vacca 5664

Valdre 5949

Valle 5267

Van Atta 5645

Van Der Meer 5014

Van der Py1 53715575

Van der Scheer 5039

Vanderschmidt $\quad 58118 \quad 5901 \quad 59141 \quad 59148$

Vandersilice 6090

Vanderveer 5258

Van der Waal 6022

Van Dorn 60119

Van Heerden 5537

Van Koppen 5364

Van Steenwinke1 57016012

Van Valkenburg 4619

Van Voorhis $2502 \quad 2602$

Van Vucht 6045

Varadi $5450-5605$

$\begin{array}{lllllll}\text { Varicak } & 5561 & 5619 & 5627 & 5783 & 58119 & 5967\end{array}$

Varnerin $5435 \quad 5517 \quad 5720$

Veis 5934

Veith 4409

Vekshinsky 5935

Venema $5429 \quad 5815 \quad 58141 \quad 592459365982$

Verhoek 3906

Verkamp 5620

Vermande 5242

Verna 5985

Vickers 5221

Viswanthan 5989

Vitkus 59150

Vodar 5142

Voege 0602

Voelker 3210

Voge1 5628

Volcker 5157

Volmer 2506

Von Angerer 3103

Von Dardel $5215 \quad 5365$

Von Eichborn 4408

Von Engel 51245351

Von Friesen 4016

Von Meyern 33083410

Von Smuluchowsk1 1102

Von Ubisch $4704 \quad 4806 \quad 5156 \quad 5158 \quad 5215 \quad 5241$

Von Weiss 5682

Von Zahn 58146

Voronina 6091

Vosicki 5561
Vreeland 5959

Wade 5144

Wagener J. S. 5728

Wagener S. $500951075145 \quad 5205530853665405$ 5406

Wagner 3603

Waits 6085

Wakefield 58163

Wakerling B492

Walden 3713

Waldron B594

Waldschmidt 5447

Wallace 5258

Walmsley 3708

Warmoltz 5159520855045562561658117

Warnecke M. $58123 \quad 5974 \quad 6007$

Webber 4606

Weber $1701 \quad 3708 \quad 4406 \quad 4710$

Weidemann 4101

Weinhart $3105 \quad 5042$

Weinreich $5110 \quad 5207$

Werner 3910

Weise 4307

Weissmann $5317 \quad 5574$

Weisz 4012

Wells $5777 \quad 5884$

Wenk 5005

Werlefn 5167

Werner 5055

Wesse1 5322

West 1903

Westendorp 5426

Westinghouse Mfg. Co. 6077

Westlake 60111

Westmeyer 4012

Wetterer 3903

Weulersse 6088

Wex1er 5416

Wey1 4714

Wheeldon 59133

Wheeler 5243

Whitechurch 6048

White D. 5435

White W. C. 4814

Wichers 4204

Wieder 5813

Wiederhorn 5959

Wiedmann 4624

Wilder 5010

Wildhack $4208 \quad 5772$

Wilkins $3812 \quad 3813$

Wilkinson 6082

Williams C. B493

Williams J. L. 5828

Williams R. L. 5822

Williams S. E. 4611

Williams S. L. 5620

Williams T. W. 4618

Williams W. E. 5103

Willmarth 58151

W11son D. C. 6092

Willson J. L. 3209

Wilson M. K. 5462

Wing 4202 
AUTHOR INDEX

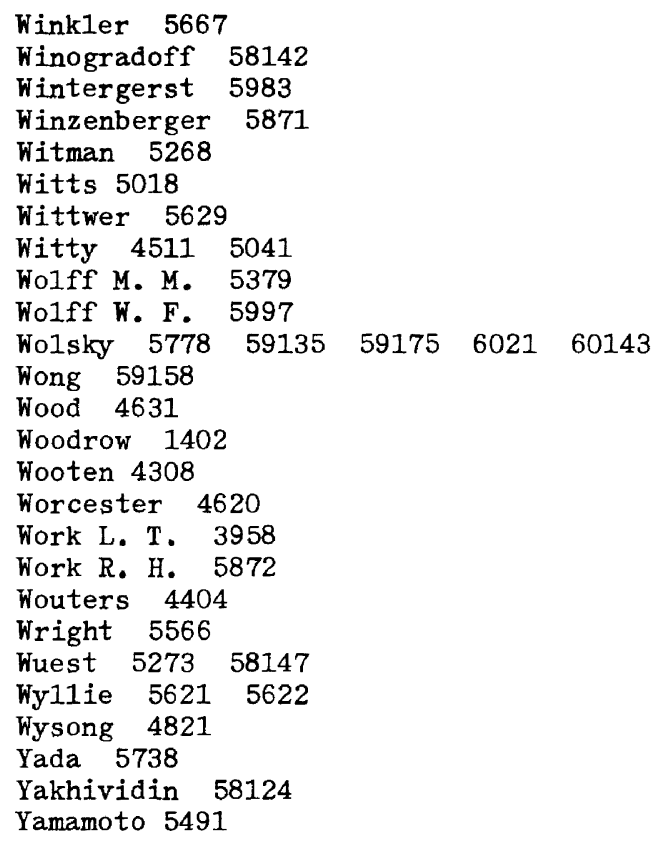

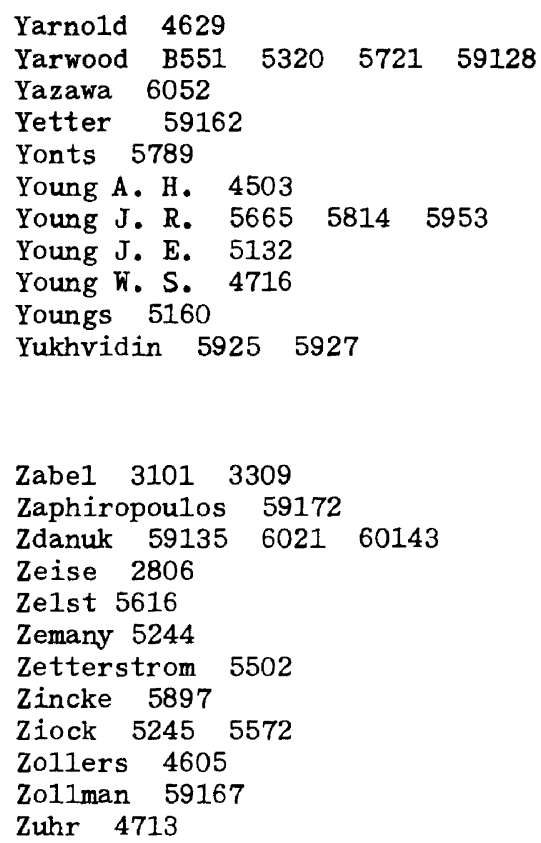




\section{SUBJECT INDEX}

The subject index covers the material in the references as completely as possible, based mostly on a perusal of the reference, in some cases on an abstract and rarely only on the title.

The headings require some discussion. Outgassing and degassing are indexed under "Degassing" for convenience, since the phenomena are in many cases too closely related to be easily separated. For the same reason, papers on permeability and diffusion are indexed under "Diffusion of gases".

Gettering action has been covered under five headings: "Getters," under which gettering materials are covered; "Ion pumps" and "Getter-ion pumps," under which specific designs are covered; "Gettering action, ionization gages," the importance of which seemed to warrant a separate heading; and last, "Clean-up of gases, electrical," under which gettering action not otherwise covered is indexed.

Micromanometers cover the class of low pressure$$
\text { l. }
$$$$
\text { A borption, see Adsorption, Degassing, Diffusion of }
$$

instrumentation which it is desired to discuss. Two headings are used, "Micromanometers, liquid type" and "Mechanical pressure and vacuum gages." The latter heading is preferable to "Micromanometers" because many designs of mechanical micromanometers have possible application to the vacuum range.

Finally, a distinction has been made between gaskets and seals. Mainly the design or physical properties of the gaskets are covered under "Gaskets," and the application and assemblies under "Seals."

In using the index, note that under the heading "Pressure measurement" al1 types of vacuum gages and micromanometers are 1 isted under the various nomenclatures in use, with a reference to the heading under which it may be located in the index. The same has been done for pumps under the heading "Pumps."

Accommodation coefficient (cont'd)

Nitrogen 15013401

P1atinum 38134401

Temperature coefficient 3813

Nitrous oxide 3401

Organic compounds, low vapor pressure 3906

0xygen 3401

Platinum 34023813

Temperature coefficient 3813

Review B571 1101

Significance in heat conduction 1101

Sulfur dioxide 3401

Temperature coefficient 33023804381339024205 4302

Theory 3202330234013813

Xenon

Platinum 4401

Acoustical vacuum gage 56635773

Adsorbing materials, characteristics of

Barium, see Getters

Carbon, see

Charcoa1, see

Crysta1s, porous $B 583$

Energetics B583

Gases adsorbed, see Adsorption

Getters, see

Palladium, see Hydrogen, Palladium

Pore structure B583

Silica gel, see

Theory, see Adsorption

Titanium, see Getters, Getter-ion pumps

Zeolites, see

Zirconium, see

Adsorption, see also Getters, Adsorption, activated Acetic acid G1ass 4717

Acetone Silica 3509

Acetonitride Silica 3509

Acetylene

Air Charcoal B491

Mercury B321 
SUBJECT INDEX (cont'd)
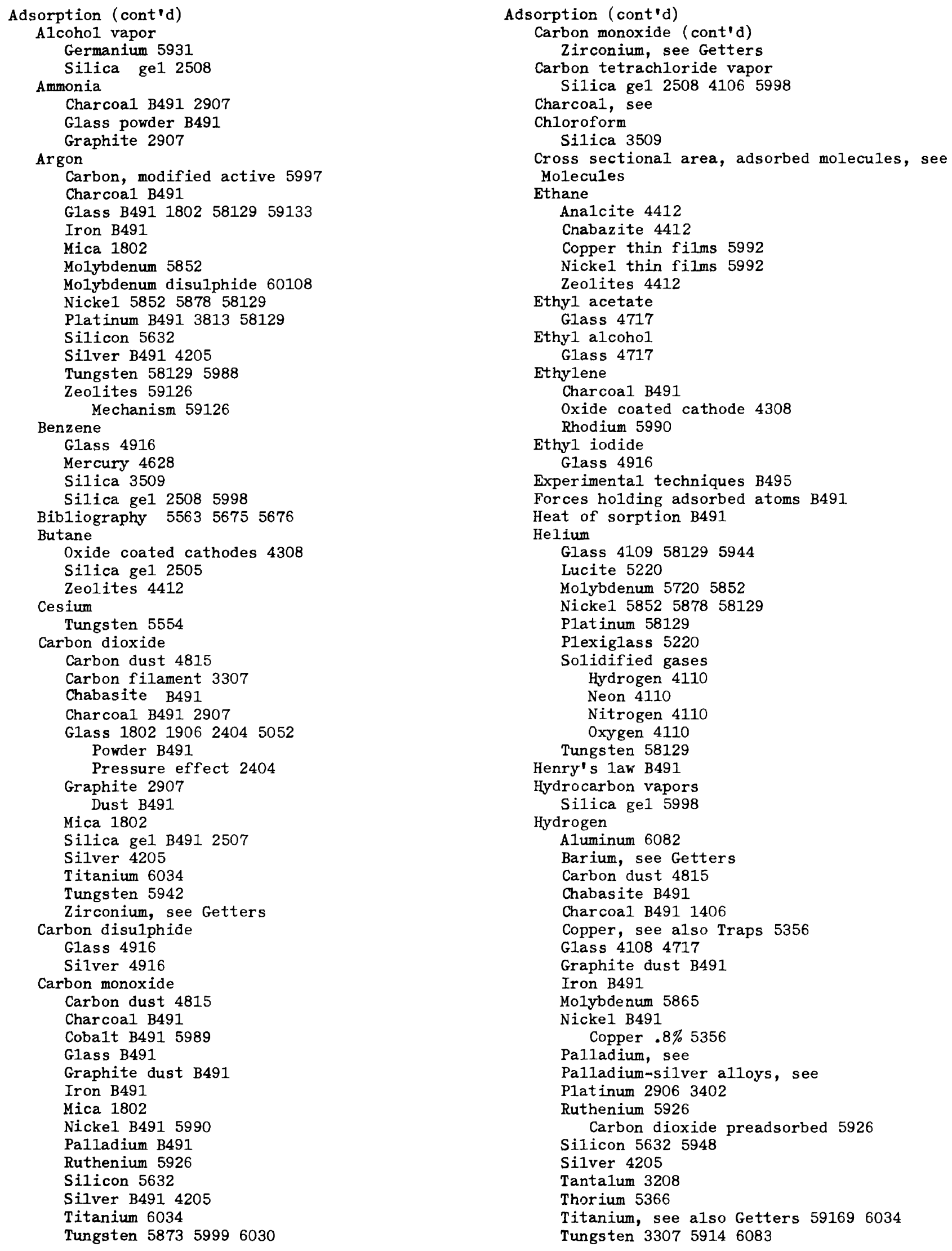


\section{SUBJECT INDEX (cont'd)}
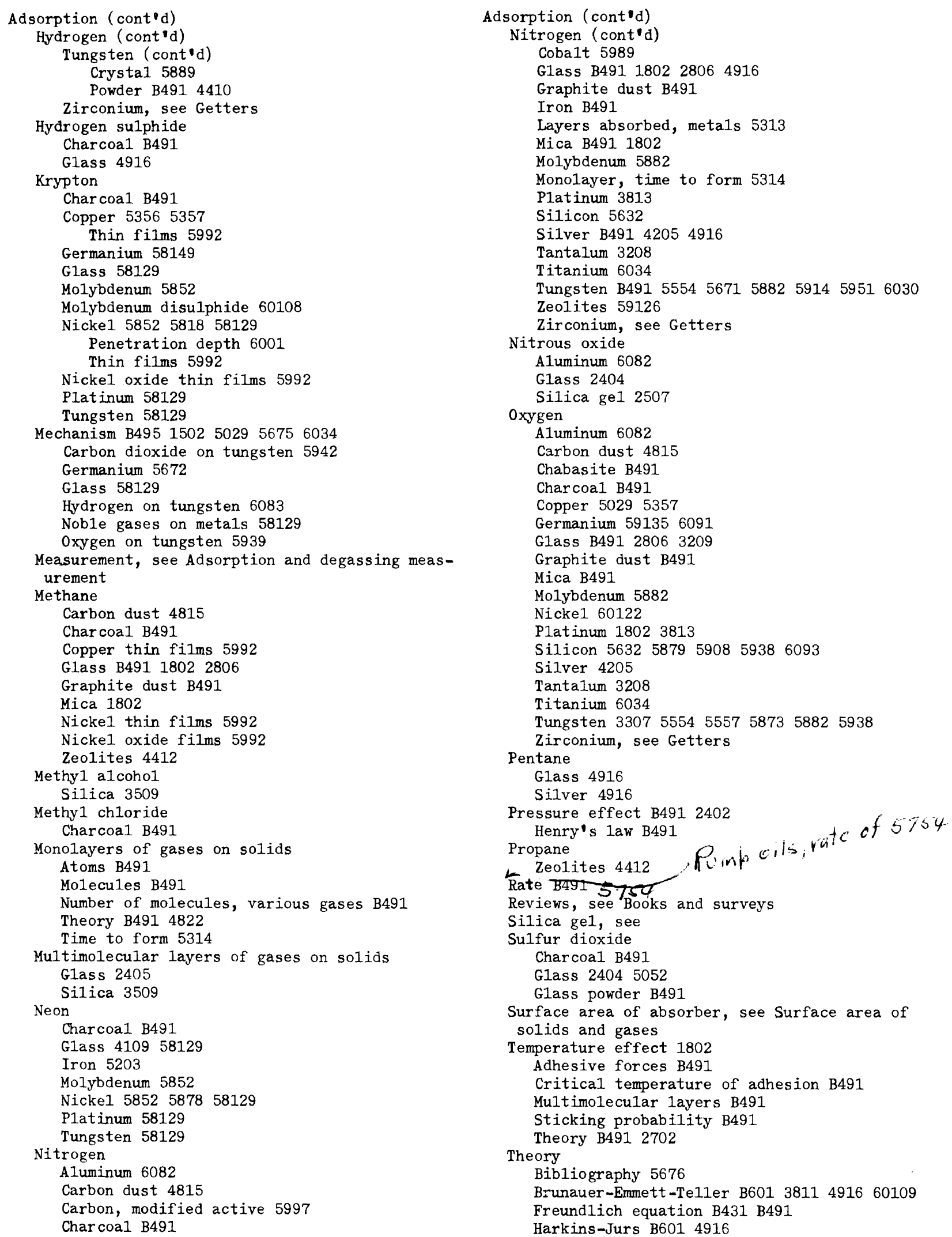
SUBJECT INDEX (cont'd)

Adsorption (cont'd)

Theory (cont'd)

Hyperbo1ic isotherm B341 B491 250635083614 4041

Combined with parabolic B491 28062906

Tungsten-hydrogen 4410

Interactions between molecules 6098

Langmuir (monomolecular 1ayer) B601 1502

1802330735084015

Monomolecular layer 29084822

Langmuir, see above

Temperature effect 2908

Monomolecular layer on metals

Atoms B491

Molecular B491 3307

Physical basis B491 1502

Temperature effect $B 491$

Multimolecular layers B321 B431 B491 Brunauer-Emmett-Te11er B431 B491 B601 3811 Condensible vapors 4509

Nitrogen on various materials, below $-183^{\circ} \mathrm{C}$ B491

Palmer, virteous silica B491

Patrick, silica gel B491

Polanyi B321 B431 B491 B601 2702

Organic vapors by silica 3509

Parabolic isotherm B431 B491

Persorption B491

Porous solids 60109

Potential, see Multimolecular layers above

Review B491 B495 Bb01_ Kate 5754

Statistica1 basis B491 38124015

Temperature effects B491

Thermodynamic basis 3812

Toluene

Glass 4916

Water vapor, see also

Chabasite B491

Glass

Experimenta1 data B491 180219064417 491657325894

Temperature effect 5732

Mechanism B491 52465894

Theory 5246

Quartz B491 58150

Silica gel B491

Hysteresis 1oop 4106

Stee1 4602

Tantalum 3208

Zeolites B491

Xenon

Charcoal B491

Adsorption, activated or chemisorption, see also

Gettering action, ionization gages

Carbon dioxide

Produced on glass by activated oxygen 4018

Carbon monoxide

A1uminum 6082

Mo1ybdenum 6031

Produced on glass by activated oxygen 4018 Tantalum 6031

Chlorine

Dissociation by tungsten cathode 1502

Ethylene

Aluminum 6082

Getters, see

Hydrogen

Breakdown to atomic

Electron bombardment 27032704
Adsorption, activated or chemisorption (cont'd) Hydrogen (cont'd)

Breakdown to atomic (cont'd)

Tungsten filament 14011502

Characteristics for classes of metals B472 B491

Tungsten filament 6083

Zirconium 4905

Mechanism 130158130

Metals 5670

Methane

Various cathodes 58130

Nitrogen B491

Magnesium 3110

Molybdenum filament 1907

Tantalum 3208

Tungsten filament 130213041401

Zirconium 4905

Nitrogen oxide

Aluminum 6082

Oxide films

Formation and stability 4206

Iron

Location by electron microscope 5653 Tungsten 4821

Oxygen

Activated by hot filament 4018

Barium, see also Getters 5204

Germanium 59966091

Iron 5653

Magnesium 3303

Tantalum 3208

Tungsten filaments B491 130113041502

Zirconium 4905

Review B472

Theory B601 1502

Sorption by metals B491 5670

Water vapor

Barium 6032

Produced by activated oxygen on glass walls 4018

Tanta1ium 3208

Tungsten 1304

Adsorption and degassing measurement

Accumulation method 6034

Applications

Adsorption 3712531254305554577858825914

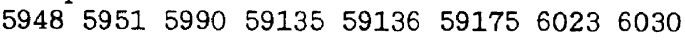
60122

Electron tubes 601860206034

Glass 4714

Silicon 5632

Degassing $2302 \quad 4824 \quad 5312 \quad 5612 \quad 5759 \quad 5768 \quad 5778$

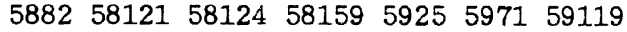

$\begin{array}{lllllll}59136 & 59153 \quad 59157600160236034 & 608060123\end{array}$

Diffusion 58121

Gettering 3209500951625205543059136

6046604760486053

Compression of gas

Capillary tube, in 5759

Conductivity of nicke1 oxide determines getter-

ing of oxygen 6046

Contact resistance, measures adsorption of

gases on molybdenum and tungsten 5882

Diffraction, low energy electrons 60122

Electron tubes

Ionization gage circuit measures residual

gas pressure 6018

Field emission microscope 371255545988 
Adsorption and degassing measurement (cont'd)

Flash filament techniques Adsorption 594859136

Residual gases by tungsten 591459136

Number of gas layers absorbed 5313

Mass spectrometer plus pressure drop measures adsorption 5632

Flowmeter, microvane deflection 6034

Gas analysis, see

Getter-ion pump, current integration 60123

Infrared spectrum of fresh1y formed metal films

in presence of gas 5990

Mass spectrometer, see

0at1ey method 5445

Omegatron, see Mass spectrometers

Polarized 1ight

Multimolecular layers absorbed 4717

Pressure change vs time 2303320951625883

Differential pressure, pump operating through known conductance 500951625205576858121

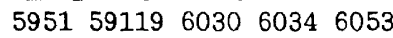

Theory 57686034

Pressure change in system, pump operating through orifice of known conductance 5445 5971

Theory 54455971

Pressure drop in reservoir getter chamber pressure held constant 60476048

Pressure rise

In orifice of known conductance 58159

Ionization gage, palladium window admitting hydrogen only 6080

Radinactive tracer 5430

Krypton 85, 5612

Penetration depth in nicke1 6001

Surface area of solids, see

Weighing

Electrica1ly operated beam balance 4824

Microbalance 577859135591756021

Zabe1 method 59153

Theory 59153

Alphatron, see Radioactive ionization gages

Amplifiers, electronic

Electronic B542

Transistor $\mathrm{B} 602$

Analcite, see Zeolites

Anode materials

microwave tubes 6026

Anemometers, vacuum, see Flowmeters, vacuum

Argon

Adsorption, see

Degassing, see

Diffusion, see

Atmospheric pressure oscillations, measurement of,

see Pressure measurement, Microbarographs

Bib1iography

Acoustic and explosion waves 59177

Backstreaming, see Pumps, diffusion

Ballast gas, mechanical pumps, see Pumps, mechanica1

Barium

Contact potentia1, tungsten 3502

Getter, see

Melting point curve 6050

Oxidation

Mechanism 5735

Theory 5708
Barium (cont'd)

Photo absorption 5030

Purity 6050

Structure, getter films 60516052

Surface area, active 60506051

Work function 35023808

Barometers, see also Manometers

Aneroid, nu11 type 5490

Review 6009

Standard NPL 6092

Vacuum valve 545560126

Barostat, see Pressure regulator

Batalum getter 3708

Bayard-Alpert gage, see Ionization gage, Bayard-

Alpert

Bibliographies

Acoustic and explosion wave propagation in

atmosphere 59177

Adsorption 55635676

Altimeters 5575

Aneroid barometers 5575

Bourdon tubes and gages 5371

Diaphragms 5575

Diaphragm pressure gages 5575

Electrical clean-up of gases by hot cathodes 5919

Gas analys is 19495026

Getters,

Barium for carbon monoxide 6006

Electron tubes 5010

Leak detection 5233

Mass spectrometers B594 5015 (1949)

Applications 58103

Materials

Electron devices B591

Mica 5940

Vacuum applications B593

Molecular beams 4622

Molecular processes, gas-solid interface 59176

Pirani gages 4704

Pressure measurement, dynamic 54815540

Quartz 5890

Radiometer gages 5125

Surface area of solids 5165

Vacuum insulation, electrical 60128

Vacuum measurement B571 51055113

U1tra high 5874

Vacuum pumps 48175848

Vacuum techniques B591 516659114

High 60120

U1tra-high 5874

Valves 5320

Vapor pressure 4712

Bimeta1 strip Pirani gage, see Expansion gages, therma1

Books and Surveys

Adsorption B321 B341 B431 B491 B495 B514 B521

B581 B601 3307567559176

Chemisorption B601 5675

Monolayers on solids 4015

Theories B431 B495 B601 4015

U1tra-high vacuum 5874

Cathodes, oxide coated 3907

Conductance of tubes and orifices B491 B492 B501 B506 B512 B581

Desorption (Degassing) B491 B581 B591 3109

Glass B543

Meta1s 5631 
Books and Surveys (cont'd)

Diffusion of gases, thermal 4623

Diffusion through solids B472 B522 B581

Electrical discharges in vacuum 5316

Electronic and ionic impact phenomena B524

Electronics, applied B542

Evaporation rates, metals $\mathrm{B} 491$

Field emission microscopy B511 5684

Fluid velocity and pressure B241

Gas ana1ys is 1949,5026

Gases, Kinetic theory B381 B471 B491 B501 B502 B506 B512 B581

Molecular flow B561

Getters B581 B591 44155010

Barium for carbon monoxide 6006

Glass, Properties of B543

Meta11ising 5143

Handbook, vacuum B504

Ionization gages 510551135144

Cold cathode 5311

Ultra-high vacuum 5874

Ionization phenomena $\mathrm{B} 603$

Leak detection B491 B492 B493

McLeod gage B491 B515 B571 4615510551135166

Mass spectrometry B531 B582 B594 60125 Applications 58103

Materials, vacuum app1ications B593

Materials, vacuum tubes B591

Mercury barometers and manometers 6009

Mica 5940

Micromanometers B391 B496 B533 5105

Tilting B241 B496

Molecular beam techniques 4622

Outgassing, see Desorption

Pirani gages B491 B571 47044903510551135144

Pressure gages, 10w B391

Pressure measurement, dynamic 5481

Pump oils 4414

Pumps, see Vacuum pumps below

Radiometer gages B491 B571 510551135125

Seals, glass to metal 5348

Solubility of gases in solids B522

Sorption of gases and vapors, see Adsorption above

Surface area of absorbents 4508

Surface chemistry B514 B601

Surface physics 59176

Surface tension B494

Thermionic emission 5678

Transducers B592

Vacuum evaporation and metallurgy B513 B572

Vacuum distillation, pump oils 4414

Vacuum gages B382 B391 B491 B492 B506 B521 B551 B571 B581 46155105 5113 51445875

Calibration methods B491 B501 B502 B571 4615

Ionization gages, see above

Mcleod, see above

Pirani, see above

Radiometer, see above

Upper atmosphere pressure B532

Vacuum insulation, electrical 60128

Vacuum pumps B382 B491 B492 B502 B506 B512 B521

B551 B572 B581 31094817514958485875

Pumping speed B506 B512 B551

Vacuum techniques B261 B382 B473 B491 B492 B502

B503 B504 B505 B521 B523 B551 B581 31095134

5166591065911459132

U1tra-high vacuum 58745915
Books and Surveys (cont'd)

Valves 5320

Vapor pressure

Inorganic compounds 4712

Organic compounds B541 4712

Pump oils B581

Solids B491 5527

Viscosity gages B491 5113

Bourdon tube gages

Bibliography 5371

Glass B391

Collapsab.le 3405

Light beam B491 0901

Pointer B491 3405

Quartz B491

Light beam B491

Review, vacuum measurement 4615

Silica B391

Bourdon tubes

Bibliography 5371

Theory 527252735679

Brazing techniques

Nicke1 5258

Vacuum 58595887

Buna rubber, see Rubbers

Butyl rubber, see Rubbers

Ca1ibration techniques, vacuum gages

Constant leak, orifice in two positions

Pumping speed known, pressure gage linear 59147

Expansion of gas method B391 B491 B501 B571 1403

321249095310

F1orescu 59147

F1ow-pressure drop method B491 B501 B571 2101

37095124587459147

Across aperture in diaphragm 58155

Tneory 2101

Ionization gages

Expansion of gas method 5310

Location in vacuum system 6016

Pumping speed and gas flow measured at gas exit 5609

Secondary standard 572558107

Magnetron

Using Bayard-Alpert gage 5944

McLeod gages 5474

As standard, see McLeod gages

Expansion of gas method 3212

Review B491 B571 4615

Measured gas volume added to system 5242

Radiometers

As standard, see Radiometer gages, app1ications

Review 6016

System

Comparison method, pressure rise technique 60136

Capillary depression, see Surface tension, mercury Carbon

Adsorbed layer in vacuum systems 5315

Carbon dioxide

Adsorption, see

Degassing, see

Getters, see

Origin in vacuum systems 5308 
SUBJECT INDEX (cont'd)

Carbon adsorber $\mathrm{B} 583$

Modified active

Argon 5997

Nitrogen 5997

Carbon monoxide

Adsorption, see

Degassing, see

Getters, see

Origin in vacuum systems 5308

Cartesian diver, see Micromanometer, 1iquid type, gasometers,Pressure controllers

Cast metals

Effect of adsorbed gases B491

Catalys is

Carbon and oxygen on tungsten 5554

Hydrogen and oxygen on tungsten 5554

Cathodes

Iridium

Performance 5110

0xide coated

Degassing, using cold trap for $\mathrm{CO}_{2} 5748$

Electron emission, see Electron emission from cathodes

Properties 3907

Thoria covered iridium and rhodium

Rhodium Performance 5110

Performance 5110

Ce1lulose, sorption and desorption B491

Cements, properties B551

Vapor pressure, see

Centrifugal manometer, see Mechanical pressure and vacuum gages

Ceramics, properties, see Materials

Chabasite absorber, see Zeolites

Charcoal absorber

Absorption of gases vs pressure and temperature B491

Activation methods $B 491$

Ammonia 2907

Larbon dioxide 26062907

Polanyi potential theory 2702

Carbon monoxide 2606

Liquid air temperatures 1801

Carbon monoxide 2606

Hydrogen 14062606

Nitrogen 26065976

Nitrogen 26065976

0xygen 2606

Physical characteristics B491 1406

Porosity, see

Pump 6039

Liquid nitrogen temperature 5976

Review B321 B491

Surface area B491

Theory, absorption in vacuum systems B491 3811

Tine lag B491

Chemisorption, see Adsorption, activated or chemisorption

Clean surfaces, see Surface reaction phenomena and techniques

Glass, see

Nicke1, see

Silicon, see

Titanium, see

Tungsten, see

Clean-up of gases, electrical, see also Degassing,

Getters
Clean-up of gases, electrical (cont d)

Carbon arc

Air, argon, hydrogen 5789

Electrical discharge, cold cathode

Clean-up by cathode sputtering B491

Clean-up by positive ions entering cathode Helium 5153

Neon 3615

Rare gases $B 491$

Review B491

Electrodless discharge

Air, hydrogen, nitrogen, oxygen clean-up

B491 2803

Argon 2803

Mechanism of clean-up B491

Hot cathode, see also Gettering action, ionization gages

Air 3308

Bib1iography 5919

He1ium 3410

Hydrogen 3308

Magnetic field effect 33083410

Mechanism 5919

Nitrogen 3410

Review 5919

Sealed systems, data 5309

Theory 59125

Triode

Mechanism 2406

Ionization gages, see Gettering action, ionization gages

Cold traps, see Pumps, crygenic, Traps

Compression type vacuum gage, see a1so Mcleod

gages

Differential pressure measurement 5438

Condensation coefficient

Carbon dioxide B491

Carbon monoxide

Mercury 59159

Tungsten 6030

Hydrogen B491

Glass 2806

Mercury 59159

Silicon 5948

Tungsten 520658896083

Methane B491

Glass 2806

Nitrogen B491

G1ass 2806

Mercury 59159

Metals 5313

Tungsten 520659516030

Oxygen B491

Copper 5206

Glass 2806

Mercury 59159

Silicon 5938

l'ungsten 520655575938

Review 5915

Temperature effect B491

Theory B491

Conductance of tubes and orifices, see Flow of gases

Controlled gas leaks, see Leaks, controlled gas

Controller, 1iquid level, see Traps

Controller, pressure, see Pressure controllers

Convection manometer

Thermocouples measure temperature above and

below heated strip 568059118

Jryogenic pumps, see Pumps, cryogenic 
Degassing, see also Getters, Clean-up of gases, electrical, Residual gases

Aluminum 581525815959153

Composition of gases B491

Oxide film effect $B 491$

Water vapor 5360

Anode materials, long periods of time 5883

Araldite 581525815959100

Brass 580459153

Brazing, vacuum 5859

Buna rubber, see Rubbers

lements 5321

Ceramics 592559153

Copper 580459153

Composition of gases B491

Embritt1ement by sorbed gases B491

Enameled 59100

Copper-coated nicke1 iron alloy B491

Dural 59153

Elastomers 59153

Electron tubes, see Vacuum tubes, below

General considerations, room temperature 5779

Germanium 59135

By ion bombardment 56725880

Glass, see also

Acetylene 2404

Air

Dry B491

Moist B491

Argon 58129

Carbon dioxide 190623032404

Composition of absorbed gases B491

composition of glass 2303

Sealing to metals 5528

Vacuum applications 5528

Degassing techniques B491 B591 23032405

Electron bombardment 6004

Infrared heat 5048

Helium 5812158129

Hydrogen 581216032

Induced by electrical discharge B491

Krypton 58129

Neon 58129

Nitrous oxide 2404

Oxygen 6004

Preheat effect

Review B382 B491 B543 57035897

Silicone 5804

Sorption, solution effects B491

Sputtered metal film reduces 5703

Sulfur dioxide 2404

Temperature effect 230358121

Water vapor B491 190623036032

Ion bombardment 5246

Mechanism 5503

Various glass compositions 5503

Glypto1 5869

Graphite

Composition of gases B491 4415

Techniques B491 4415

Volume, adsorbed gases 4415

Greases, vacuum, see

Insulators 59100

Ionization gages 53505802

Bayard-Alpert 5310

Co1d cathode 531253475506

0 il vapor causes abnormal 5727
Degassing (cont'd)

Iron 6034

Composition of gases B491 4416

Nicke1 plated 6034

0xygen content B491

Techniques B491 5203

Volume of adsorbed gases 4416

Lead gaskets 5032

Liquids

Refluxing through cold trap 5633

Measurement of gas evolved, see Adsorption and degassing measurement

Metals

Re-emission, noble gases, caused by ionic impact 5767

Review 5631

Mica 5940

Molybdenum 59153

Composition, adsorbed gases B491 4415

He1ium 5720

Mechanism 5720

Nitrogen 5882

0xygen 5882

Techniques B491 320644155368

Volume, adsorbed gases 4415

Monel metal wires B491

Mylar 58045869

Neoprene, see Rubbers

Nicke1 58152591536034

Argon 58129

By ion bombardment 585258785880

Carbon monoxide source of 3607

Composition of gases B491 441659130

Helium 58129

Krypton 581296001

Neon 58129

Oxygen 60122

Techniques B491 441658129591306035

Volume of adsorbed gases 4416

Ny1on 58159

Palladium

Deuterium 6089

Hydrogen 6089

Perbunan, see Rubber

Plastics (46) 59153

Platinum

Argon 58129

He1ium 58129

Krypton 58129

Neon 58129

Plexiglas 580458152

Polyviny1 chloride 58045869

Porcelain, enameled 58152

Pump oils, see

Resin

Epoxy 580458696033

Review

Ana1ysis 5805

Data B581 5804

Techniques B471 B491 B551 5805

Metals B591

U1tra-high vacuum 5874

Rubbers, see

Silicon

By ion bombardment 5880

By heating under ultra-high vacuum 5908

Silver 5815259153

Silver chloride 60103 


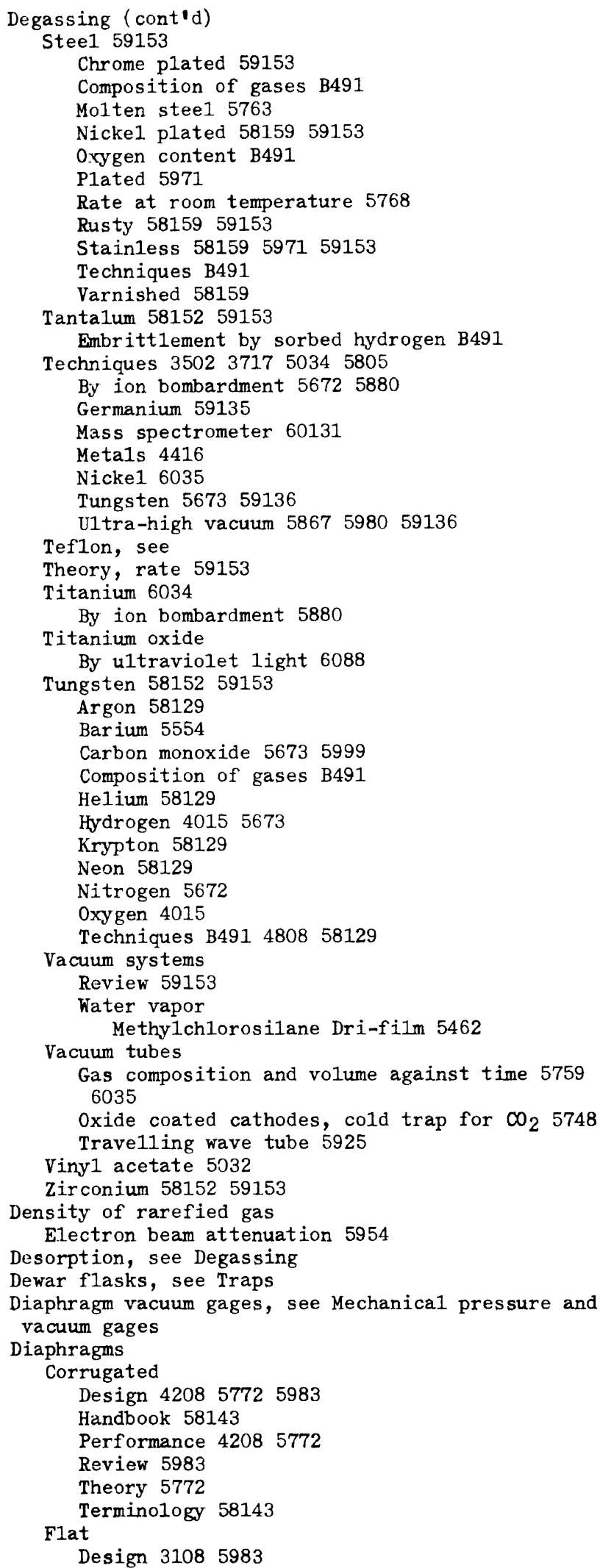

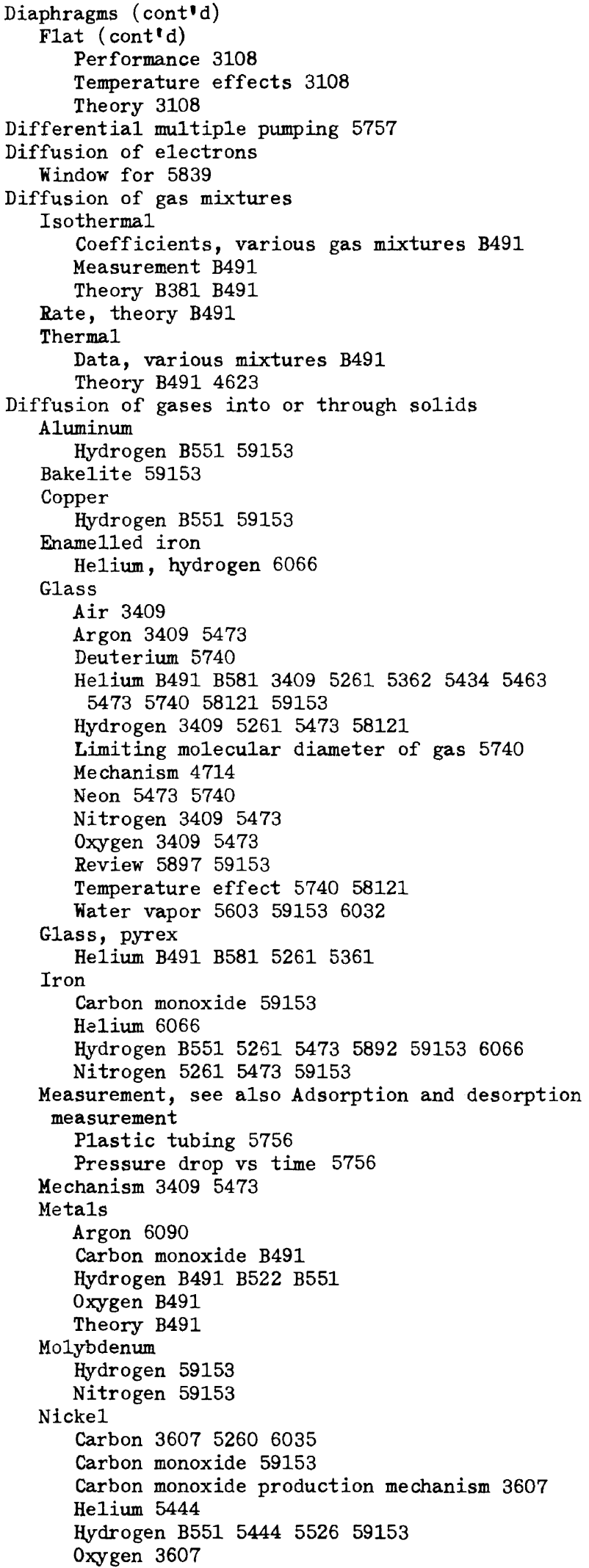


Diffusion of gases into or through solids (cont'd)

Palladium, see

Platinum Hydrogen 59153

Polymers 5740 Air

Viny 1 tubing 5756

Argon B522

Carbon monoxide B522

Carbon dioxide B522

Hydrogen B522 5261

He1ium B522

Nitrogen B522

Water vapor B522

Porcelain 59153

Pyrex, see Glass, above

Quartz

Air 3409

Argon B472 B491 B581 3409

Deuterium B581

He1ium B491 B581 3409

Hydrogen B472 B491 B581 3409

Mechanism B472 B491

Neon B472 B491 B581

Nitrogen B472 B491 B581 3409

Oxvgen B491 B581 3409

Temperature effect $B 491$

Review B472 B491 B522

Rubber, see

silicon dioxide (Silica)

Argon $\mathrm{B} 5 \overline{81}$

He1ium B581 5362

Hydrogen B581

Neon B581

Nitrogen $B 581$

Silver

Oxygen B551

Stee1

Deuterium 5822

Hydrogen 58225892

Oxygen 59153

Temperature effect B551 B581 3409

Theory B472 B491 B522 5164

Vycor 6003

Thorium

Vycor

Hydrogen 60111

Helium 53626003

Hydrogen B491 6003

Neon 6003

Nitrogen 6003

Oxygen B491

Zirconium

Hydrogen 5726

Diffusion pumps, see Pumps, diffusion

Displacement measurement, see Transducers

Draft gages, see Manometers, 1iquid type, Mechanical pressure, and vacuum gages

Dubrovin manometer, see Micromanometers, 1iquid type

Dynamic pressure measurement

Barium titanate crystals, see Piezoelectric

gages

Bibliography 5540

Piezoelectric gages, see

Review 54815540

Theory

Diaphragm plus pressure line 5487
Dynamic pressure measurement (cont'd)

Theory (cont'd)

Earth satellite 5787

Rockets 5623

Time lag 5846

Ejector pumps, see Pumps ejector

Electrical analogue, vacuum systems 5345

Electrical discharge in gases

Breakdown, coaxial cylinders, magnetic field Data, various cases 5344

Theory 5344

C1asses 5316

Clean-up, See Clean-up of gases, electrical

Glow discharge, magnetic field effect 5264

Ionization, see

Magnetic field effect 53165551

Argon 5485 Theory 5485

Mechanism B491

Pressure indicated B491 B581 43055144

By color, particular gas 4305

By discharge current or voltage drop in magnetic field 5551

By magnetic field strength at which discharge starts 5551

G1ow geometry 5055

Review 5316

Electrical mass filter partial pressure gage, see

Mass spectrometers

Electron emission from cathodes

Co1d cathodes 5316

Columbium B491

Current to positive grid in electron tubes 4504 Theory 4504

Molybdenum B491 Effect of adsorbed gases 5368

Oxide coated cathode B491 3907

Barium-strontium carbonates coated nicke1 and platinum 5406

Effect of various gases 5406

Barium-strontium oxide coated nickel

Effect of various gases 4906

Emission improved by hydrogen 6057

Review 5678

Temperature variation by current flow 60106

Review B491

Space-charge B491

Tantalum B491

Theory B491

Discharge potential, magnetic field 5267

Review 5678

Thoriated tungsten $\mathrm{B} 491$

Tungsten B491

Effect of adsorbed gases 5673

Thorium coverage for maximum emission 60102

Electronic impact phenomena B524

Collision scattered electrons actuate photo plate 59161

Electrolysis of glass 5941

Glass

Degassing 6004

Ionization of adsorbed gases 59137

0xygen 3209

Pump oils

Decomposition 5353

Secondary electrons

Produced by electron impact on wal1 5351 
Electronic impact phenomena (cont'd)

Sorption of gases, effect on 5405

Evaporation, liquids

Pump oils

Effect of surface impurities 5223

Maximum rate

0ctoil 5224

0ctoil -s 5224

Method of measurement 5224534360117

Theory 5225

Evaporation, metals

Alloys

Incone 15849

Multimet 5849

Stainless stee1 5849

Cobalt 5849

Chromium 5849

Iron 5849

Mo1ybdenum 5849

Nicke1 5849

Pressure effect B491

Review B491

Tantalum B491 5849

Temperature effect 5849

Titanium 5849

Theory B491

Tungsten B491 5849

Zirconium 5849

Evapor-ion pumps, see Getter-ion pumps

Expansion gages, thermal

Bimeta1

Design B491

Performance B491

Theory B491

Filament expansion B491

Farvitron, see Mass spectrometers

Fiber suspensions, see Instrument suspensions

Field emission microscopy

Applications 555355545684

Adsorption 59996038

U1tra high vacuum measurement 420351615637

Description B511 3605371238095553

Emission pattern varies with pressure

Thoriated tungsten 4203

Tungsten 4203

Pinthalcyamine dye 5117

Field emission data

Adsorbed gas effect 3605

Barium layer on tungsten 38095161

Molybdenum 4007

Nicke1 4007

Nitrogen sticking probability 5313

Tantalum 5259

Tungsten 400742035161

Barium desorption 5554

Carbon monoxide, adsorption, diffusion, desorption 5999

Oxygen 5557

Surface mobility of oxygen 5367

Thoriated 37114203

Vacuum measurement 5637

U1tra-high vacuum 51615637

Work function ion effect 3606

Review 5684

Techniques 531355535554

Theory 360555535684

Field ion microscopy

Review 5684
Flash filament techniques, see Surface reaction phenomena

Flowmeters, vacuum 5417

Disk, suspended 5375

Deflection measured 6034

Force balanced by torsion fiber 5465 Impact forces 54183

Vane, a c generator Measures pressure, evaporating liquids 5343 60117

Flow of gases

Force on disk Investigation 5483

Free molecular, see F1ow of gases, free molecular

Intermediate flow, free-viscous

Capillary tubes

Argon 5226

Carbon dioxide 5226

Ethylene 5226

Helium 5226

Hydrogen 5226

Nitrogen 5226

Nomographs 6067

Tubing

Conductance

Data 4715

Ion flow Theory 47155043

In mass spectrometer 4510

Measurement 5683

Leaks, controlled gas, see

Porous medium, see Porosity

Review B491 B581

Theory B471

Applied to Mass spectrometer 4510

Kundsen B491 1305

Tubing

Conductance B491

Measured by pressure drop method 5445

Flow of gases, free molecular

Adsorption effects 5966

Theory 5966

Aperture, see Orifices, below

Capillary tubing

Flattened 5658

Theory 5658

Conductance, see also Tubing below

Graphical presentation 540454725548

Flow patterns

Ends of tubes 5650

Force on disk 5483

Isentropic f1ow B561

Leaks, controlled, see Leaks, controlled gas

Liquid air trap

Conductance B491

Mechanics of rare gases B561

Non-isentropic f1ow B561

Nomographs 540455486067

Orifices

Pressure probes

Theory 5960

Theory B491 481858236013

Pressure limit, upper 1305

Review B491 B492 B561 B581 6013

Stopcocks

Conductance for various gases B491

Thermomolecular B491 
Flow of gases, free molecular (cont'd)

Tubing

Annular 5635

Conductance 47155635

Nomograms 5472

Various gases B491 5635

End correction B491

Long B491 B581

Mass spectrometer in1et 5244

Rate of exhaust B491

Rectangular 48185635

Short B491 B581 4818

Tapered B491

Theory B382 B491 B492 B506 B512 B581 4715

$481550335244 \quad 5635,58235896 \quad 6013$

Flow of gases, viscous 5154

Annular, circular and rectangular channels

Data various gases 5635

Theory 5635

Capillaries

Graphs for computing 56025662

Noncircular cross section 5464

Reyno1ds number B491

Theory B491 B581 3716

Turbulent flow B491

Earthenware plate, unglazed

Various gases 3716

E1bows 4613

Force on disk 5483

Nomographs 6067

Pipes, see Tubing below

Porous media, see Porosity

Review B491 B581

Static tube

Theory 58100

Tubing

Conductance

Data 46134715

Theory 47155033

Poiseuilles modified 4613

Rate of exhaust B491

Force-pressure balances, see a1so Vapor pressure

measurement, Torque-pressure balances

Input pressure operates force balance, controls

flapper valve

Output pressure proportional to input 5214

Manometer, tilting, weights balance pressure Float operated electromagnetic pickup, indicates nu11 5945

Force on disk, flowing gas 5483

Free molecular flow, see Flow of gases, free molecular

Friction of metals

Effect of adsorbed gases 5132

Gas analysis in vacuum systems, See also Adsorption and degassing measurement, Leak detection, Mass spectrometers

Chemical methods

Bib1iography 5026

Review 1949, 5026

Dewpoint method 5166

Mass spectrometer, see

Review 5166

Gas flow, see Flow of gases

Gaskets, see also Seals

Application

High temperature 5962

Liquid helium temperature 5719
Gaskets (cont d)

Application (cont'd)

Liquid nitrogen temperature 59435962

Mass spectrometry 58158

U1tra high vacuum 5979

Degassing properties

Buna rubber 5032

Lead 5032

Neoprene 5814

Rubber 503258108

Teflon 50325814

Vina1 acetate 5032

Dumbel1 cross section, copper 5737

Meta1

Aluminum, cupped 5979

Between stainless stee1 flanges 5962

$0-r$ ings

Cleaning techniques

Neoprene 5953

Silicone rubber 5953

Copper 51635537

Double, space between evacuated 5339

Lead 5905

Review B492 B502 B551 B581 5415

Step-type, copper 5712

Teflon

Gasket, thin 5809

Low temperature operation 5943

Ring, spring held 5525

Wire gaskets

Aluminum 57195965

Go1d 4914585658158

Indium 573358158

Gasometer gage, see Mechanical pressure and vacuum gages

Germanium

Adsorption, see also

Alcohols 59131

Gases not adsorbed 59131

Mechanism 59131

Oxygen 6091

Degassing, see

Surface properties 5996

Gettering action, ionization gages, see also Clean-

up of gases, electrical, Getters, Ion pumps

Amoil -s B491

Bayard-Alpert gage 55335556

Argon

Two pumping speeds 5918

Helium 5556

Nitrogen 55565885

0xygen 5885

Pumping speed, u1tra-high vacuum 53105721

Theory 588559122

Buty1 sebacate B491

Chemical reactions, see Adsorption, activated

Cold cathode gage

Argon 60138

Me chanism 59171

Titanium film 6041

Nitrogen 60138

Oxygen 60138

Performance 524259171

Pumping speed, various gases 604160138

Three-electrode gage 59171

Hot cathode, see also Bayard-Alpert gage, above Air B491 5031

Argon B491 4405

Carbon dioxide B491 6049 
Gettering action, ionization gages (cont'd)

Hot cathode (cont'd)

Carbon monoxide B491 6049

Glow phenomena B491

Helium B491 5556

Hydrogen B491 B571 14014405

Magnetic field effect B491

Mercury vapor releases hydrogen B491

Metal wall tube, no clean up B491 4017

Methane 6053

Nitrogen B491 130244056049

Oxygen B571 13014405604960138

Theory 59125

Variation with pressure, voltage etc B491

Hydrocarbons B571 4708

Magnetron gage 58136

He1ium 58135

Nitrogen 58135

Measurement techniques

Differential pressure measured 4708

Gas leak measured, pressure constant 5885

Pressure change measured 4405

Mechanism B491 B571 15024017503151095665

5919604960138

Helium 5517

Molybdenum cathode

Hydrogen B491 1502

Nitrogen B491 1907

Napthalene B491

0ctoil-s B491

Performance

Pumping and pressure recovery, initial 5813 5931

Temperature effect, ambient 591385931 U1tra high vacuum 54635555

Palladium cathode Hydrogen dissociation B491

Platinum cathode Hydrogen

Dissociation $\mathrm{B} 491$

Pump oil vapors B571 4708

Review B491 B571 58745919

Silicone oil B491

Tantalum cathode

Hydrocarbons decomposed B491

Hydrogen B491

Oxygen B491

Water vapor

Decomposed B491

Theory 56655703581385931

Bayard-A1pert 5721

Tungsten cathode

Argon 1502

Bromine 1502

Carbon dioxide 1502

Carbon monoxide B491 1502

Ch1orine dissociation 1502

Dissociation B491 1502

Cynogen 1502

Hydrogen 1502

Dissociation B491 1502

Hydrocarbon decomposition B491

Iodine 1502

Mercury 1502

Methane 1502

Nitrogen B491 1502

Combines with tungsten vapor 1502
Gettering action, ionization gages (cont'd)

Tungsten cathode (cont'd)

Oxygen B491 130115025109

Dissociation B491 1502

Water vapor

Dissociation $\mathrm{B} 491$

Getter-ion pumps, see also Ion pumps

Application

Electron tubes 59746039

Electrostatic accelerator 5467

Microwave tubes 581236036

Particle accelerator 5920

Thin films by evaporation 58132

Very high vacuum 59145

U1tra-high vacuum 5867587659156040

Design

Barium 537258127

Cold cathode type 5826592260130

Cold cathode ionization gage, modified 5826

Cold trap used

Liquid helium 597059145

Liquid hydrogen 58132

Titanium $54515467 \quad 55425550 \quad 5826 \quad 5857 \quad 5888$

$\begin{array}{lllllll}58123 & 58126 & 58128 & 58131 & 58132 & 58137 & 58139\end{array}$

$\begin{array}{llllllll}58142 & 5921 & 5970 & 5973 & 5974 & 5975 & 59108 & 59111\end{array}$

59127591705917259173600760396040

6013060134

Four electrodes used 59170

High pumping speed 5813759172

Method of evaporating 58137581425973

6040

Miniature 60076040

Water cooled wa1ls 59111

Evapor-ion $53695451 \quad 5467 \quad 5542 \quad 5550 \quad 5813158142$ $5920592159706036 \quad 60130$

Ha11 Vac-ion 5876

Herb, see Evapor-ion above

Mechanism of operation 587658128581315922 60130

Performance 54595812359215922597359170 60406013060134

Cold trap used 5812659705914559173

Life of components 55505974

Poisoning by hydrocarbons 597360134

Pumping speed 546758126581285813258138

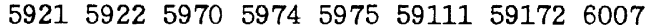
6039

Air 555058675813259215973603960134

Ammonia 5921

Argon 545155425867581285913859108

60396040

Carbon dioxide 5550581385921

Carbon monoxide 5550

Helium 545158675910860396040

Hydrogen $5451 \quad 5550 \quad 5867 \quad 58128 \quad 58132 \quad 5921$

59735910860134

Methane 55506040

Neon 6040

Nitrogen $5451 \quad 5550 \quad 58128 \quad 58132 \quad 58138 \quad 5921$

5973603960134

Organic vapors 5467

Oxygen $54515550 \quad 58127 \quad 58128 \quad 58132 \quad 58138$

59215973603960134

Water vapor 5909

Review 5909

Temperature of gettering surface 5922

Vacuum 1imit, $\mathrm{mm} \mathrm{Hg}$

$10-7,54515462581325970$

$5 \times 10^{-8}, 58138$ 


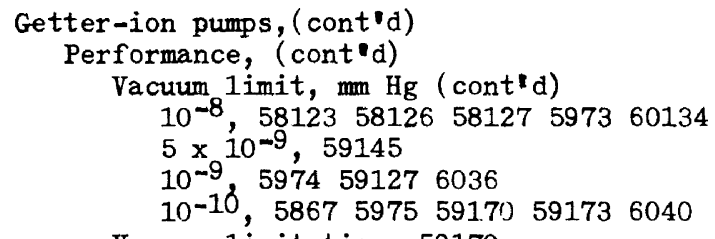

Vacuum 1imitations 59170

Review 58485857587658131592259114

Theory

Titanium pump 581396040

Tsukahoshi 5876

Vac ion 5876597559145591726039

Operating techniques

U1timate vacuum 59173

Performance 6039

Getters, see also Gettering action, ionization

gages, Getter-ion pumps

Abrasion, of metals, continuous 5881

Aluminum

Carbon dioxide 4002

Hydrogen 4002

Nitrogen 4002

0xygen 4002

Review B491

Aluminum-barium mixture 3717

App1ications

Vacuum tubes 5817

$\mathrm{X}$-ray tube, sealed in getter

Barium

Performance, various gases 6043

Acetylane 6042

Air 5407540857105806

Area 6050

Argon 5710

Black and bright B491 3403

Carbon dioxide 400242015107540754085710

580660426049

Carbon monoxide 42015107530854075408

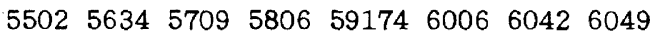
6054

Efficiency 50355994

Evaporated in argon atmosphere improves gettering B491 4201

Evaporated in mercury vapor atmosphere

destroys gettering 4002

Gettering capacity defined 5408

He1ium 4201

Hydrogen 3403400251075407540857105806 59174604260496056

Mechanism 510758665917460426049

Methane 60426053

Nitrogen 3403400242015107540754085710

$58065866 \quad 59174 \quad 604260496055$

0xygen $40025107516252045308 \quad 54075634$

57075710580660426049

Mercury vapor present 6046

Review B491 52055308540858176006

Structure, evaporated films 60516052

Techniques B4915710 591746043

Liquid air trap 59174

Temperature effect

Air 5407

Carbon dioxide 5407

Carbon monoxide 540757096054

Hydrogen 54076056

Nitrogen $54075866 \quad 6055$

0xygen 54075708

Water vapor 5407
Getters, (cont'd)

Barium (cont'd)

Theory B491 5866

Oxidation 5708

Vacuum tubes

Life 6042

Water vapor $5107540754085806 \quad 60326042$

Barium-aluminum

Performance 6043

Mercury vapor effect 6043

Barium-strontium carbonate mixture (Batalum) 3708

Carbon dioxide poisoning 5430

Radioactive tracer used 5430

Calcium

Hydrogen 3403

Nitrogen 3403

Review B491

Techniques B491

Carbon arc

Air, argon, hydrogen 5789

Ceto, see Thorium-aluminum below

Evapor-ion pump, see Getter-ion pumps

Gettering capacity defined 5408

History 5817

Incandescent lamps

Various getters used B491

Ionization gage, see Gettering action, ionization gages

Magnesium

Air 4002

Carbon dioxide 34034002

Carbon monoxide 3403

Hydrogen 330634034002

Mercury vapor effect 4002

N1trogen 311034034002

Oxygen 34034002

Review B491 5205

Measurement, gettering, see Adsorption and

degassing measurement

Mechanism, see also Barium, above

Clean-up by sputtered metal 6090

Misch metal (rare earth alloy)

Carbon dioxide 4002

Hydrogen 4002

Mercury vapor effect 4002

Nitrogen 4002

Oxygen 4002

Review B491

Selective getter Desorbs hydrogen slowly 6057

Moly’denum Hydrogen 5865

Phosphorous pentoxide Hydrogen gettered by vapor B491

Review B471 B491 B581 B591 441550105848 Patents 4415 U1tra-high vacuum 5874

Sodium, during evaporation B491

Thorium

Carbon dioxide 4002

Hydrogen 40025366

0xygen 40025366

Review B491 40025205

Tnorium-aluminum ( Ceto)

Performance, hydrogen 6045

Physical properties 6045 
Heat conductivity gages, see Expansion gages, therma1, Pirani gages, Thermocouple gages Review, see Books and surveys

Heat conductivity of gases Accommodation coefficient, see Data 110117015215

$$
\text { Air } 5167
$$

Helium 5167

Hydrogen 3804

Hydrogen-deuterium mixtures 3803

Free molecule conductivity B491 5215 'lemperature discontinuity $\mathrm{B} 491$ Theory 5816

Various gases $\mathrm{B} 491$

Theory B491

Between

Concentric cylinders 11011501

Paralle1 plates 1102

Rough surfaces 1101

Langmuir film B491

Heat conductivity from wires to gases

Data, 25 gases 5156

Effect, wire diameter 5151

Theory 5151

Helium

Binary gas mixtures 5156

Adsorption on solids, see Adsorption

Degassing, see

Diffusion, see Diffusion of gases

Heat conductivity, see

Helium ions and molybdenum cathode 5368

Solubility

Glass 5434

Hydrogen

Accommodation coefficient, see

Adsorption, see

Degassing, see

Diffusion through solids, see Diffusion of gases

Palladium, see

Dissociation

Electron bombardment 27032704

Hot tungsten cathode 14011501

Reacts with glass 6002

Getters, see

Heat conductivity, see

Origin in vacuum systems 5308

Solubility

Elastomers B522

Metals B491 B522

Palladium B491

Theory 3715

Polymers B522

Theory B522

Vycor 6003

Zirconium 5726

Sticking probability, see Condensation coefficent

Indium, see Gaskets, Seals

Instrument suspensions

Meta1 wires 37135125

Quartz fibers 5126

Silica fibers 37135125

Insulation, vacuum, electrical Review 60128

Insulation materials, thermal

Brelite (volcanic mineral) 5122

Magnesium carbonate 5122
Insulation materials, thermal (cont'd)

Silica aeroge1 5122

Stag wool 5122

Ion current measurement, see also Ionization gages Accelerated to metal plate, secondary electrons fall on $\mathrm{ZnO}$ scintillator

Scintillations detected by photo multiplier 5683

Ion impact phenomena

Ion emission P1atinum 5917

Ionization

Efficiency 3203

Electron bombardment

A cetylene 3203

Adsorbed gases 59137

Argon 30033005

Carbon monoxide 3203

He1ium 30033005

Hydrogen 30043203

Mercury 3104

Neon 30033005

Nitric oxide 3203

Nitrogen 3203

0xygen 3203

Probability B491 25022802

Argon 3005

Helium 3005

Hydrogen 3004

Mercury 3104

Neon 3005

Review B524 B603

Theory, see also Ionization gages, probability of ionization 28023404

Various gases 2802

Ionization gages

Alphatron, see Radioactive ionization gages

Bayard-Alpert, see Ionization gages, Bayard-

Alpert

Calibration techniques, see

Cold cathode, see Ionization gages, cold cathode

Hot cathode, see Ionization gages, hot cathode

Magnetron, see Ionization gages, Magnetron

Penning, see Ionization gages, cold cathode Philips, see Ionization gages, cold cathode Photomultiplier, see Ionization gages, photomultiplier

Radioactive ionization gages, see

Reviews B471 B491 B571

U1tra-high vacuum 5874

Ionization gages, Bayard-Alpert

Adsorption, residual gases 60133

Application

Electron ejection 5314

U1tra-high vacuum 58140597959104591106079

Calibration

Linearity at ultra-high vacua, controlled

rate of change of pressure 5448

Degassing 531060133

Design 50125013510653105428547454785546

567457215815581055814059795910459110

591496079

Collector area sma11 501254285815

Electrical charge on glass envelope prevented 59102

Electron current contro1 58105

Evacuated space around instrument 5435 
SUBJECT INDEX ( cont'd)

Ionization gages, Bayard-Alpert (cont'd)

Design (cont'd)

Integrates output, measures ratio ion to

electron current 58140

Modified to lower vacuum range 54745721 59110

Additional collector, two ion currents measured 6079

Long electron trajectories 5674

Power supply regulated 5546

Review B571

Subminiature 59149

Thoria coated iridium filament 5546

Gettering action, see Gettering action, ionization gages

Performance 5012501351065310581559110

59122607160121

Linearity 5729

Low pressure 1imit 5448

Limiting vacuum

Helium diffusion through glass 5435

Sensitivity, bistable

Caused by static electricity 59102

Sensitivity ratio, ion to electron current 526658140

Not constant 60121

Sensitivity, various gases 5729

Argon 547460121

Helium 60121

Neon 5474

Nitrogen 5314547460121

Propane-butane (calor gas) 6063

Review 5310

Source of large errors

Glass encased 60113

Pressure range, high, $\mathrm{mm} \mathrm{Hg}$

$10^{-4}, 547859110$

$10^{-1}, 5729$

Pressure range, 10w, mm Hg

$10^{-5}, 5729$

$5 \times 10^{-9}, 5478$

$10^{-9}, 5106$

$10^{-10}, 5012501353145428581055814059110$

$5 \times 10^{-11}, 5310$

$10^{-11}, 5435553357216079$

$10^{-12}, 56745815$

$10^{-13}, 5474$

$10^{-14}, 5428$

Review

U1tra-high vacuum 587459113

Theory 54745914960121

Additional ion collector 6079

Linearity 1imits 59122607160121

Ionization gages, cold cathode

Applications

Leak detection 5627

U1tra-high vacuum 59104

Upper atmosphere 5769

Degassing

Cathode material effect 5312

Mechanism 5506

Methods 53475506

Design 37053706440348094904490749085016

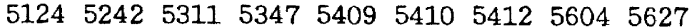

$56395705576957825811359104 \quad 6070$

Lathode materials 531153125604

Circuit

Ballast resistance controls current 5410
Ionization gages, cold cathode (cont'd)

Design (cont'd)

Circuit (cont d)

Contro1, voltage supp1y 5782

Electron current separated from ion current by phospher screen 6070

Safety against overpressure 4810

Combined with thermocouple gage B491 4809

5782

Electrode geometry 5412

Extend pressure range 58113

Third electrode added 5705

For easy degassing 5347

High sensitivity 5409

Indication method

Potentiometer, galvanometer 5627

Scintillation probe for phosphor screen 6070

Ionization methods 5311

Operates safety relay 4907

Penning B491 B571 3705370649045242

Review B491 B571

Gettering action, see also Gettering action,

ionization gages

Air B571

Review B571

Performance 3705440450165242531154095410

5412556156396070

Discharge initiation, 10w pressures $B 571$

Discontinuities in calibration curve B571

Electrode geometry effect 5412

Filament materials, effect of B571 44045604.

Magnetic field

Materials 5639

Strength effect 490854195561

Radiation detected from gage 5505

Sensitivity 501654095627

Air 5311

Helium 5311

Hydrogen 5311

Nitrogen 5311

Oxygen 5311

Propane-butane (calor gas) 6063

Pressure range, high, $\mathrm{mm} \mathrm{Hg}$

$10^{-3}, 5782$

$10^{-2}, 53115561$

$10-1,5016$

1,58113

Pressure range, 1ow, mm $\mathrm{Hg}$ $10^{-5}, 5782$

$2 \times 10-6$, with microammeter 5409

$10-6,4904$

$10^{-7}, 501653115604$

$10-10,6070$

Review B491 B571 53115539

Starter of discharge 47094809

Theory 480958113

Ionization gage, hot cathode

Applications

Industrial vacuums 5376

High pressure 57186064

Leak detection 60100

Pressure fluctuations 5378

Rockets 59575968

Secondary standard 58107

Bayard-A1pert, see Ionization gages, Bayard-

Alpert

Calibration techniques, see 
SUBJECT INDEX (cont'd)

Ionization gages, hot cathode (cont'd)

Degassing, see

Design 16011902210126043102360237073805

$\begin{array}{lllllllll}4003 & 4102 & 4103 & 4202 & 4607 & 4616 & 4617 & 4619 & 4826\end{array}$

$\begin{array}{lllllllll}5003 & 5011 & 5137 & 5206 & 5207 & 5208 & 5237 & 5254 & 5269\end{array}$

$\begin{array}{lllllllll}5365 & 5378 & 5471 & 5504 & 5558 & 5641 & 5718 & 5723 & 58115\end{array}$ 6064

Anode

Platinum film on glass envelope 4002

Thorium film on glass envelope 3501

Audio frequency monitor 4617

Combined with Pirani gage 5365

Contamination indicator

Additional heated tungsten strip 5206

Demountable 5269

Diode 5137

Electrode geometry 58115

Short electron path 6064

Various 5471

Electron current contro1 B491 B571 26044004

$\begin{array}{llllllll}4506 & 4619 & 5014 & 5208 & 5237 & 5254 & 5350 & 5365\end{array}$

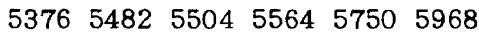

Cathode follower 5376

Double grid in ionization gage 38055003 52085504

Electronic feedback 3707410342024607

50145504556456415750

Transistor 5968

Gas tube voltage regulator, negative feedback 4004

Grid current control, automatic 5458

Relay 310534075458

Saturable core transformer 3408

Thyratron 37045108

Wheatstone bridge circuit 5482

Electron tube itself 3103

Filament

Lanthanum boride-coated tantalum

Prevents dissociation of hydrogen 6002

0xide coated 4616

Rhenium 5723

Thoria coated

Iridium 5207

Rhodium 5207

Indication, mode of

Amplifier used B571 2604520852545641

Cathode ray oscillograph 5378

Galvanometer B571

Ion current measured $3102 \quad 3407 \quad 3408 \quad 3704$ 37073805

Magic eye 41024103

Ratio, ion to electron current 52375350 5770

Wheatstone bridge, unbalanced 5504

Iova 5269

Magnetic field to lengthen electron trajectories 4826

Meta1, a11 5011

Palladium window to admit hydrogen probe gas 4505

Power supply stabilized 4619503958112 Circuit theory 58112

Review B491 B571

Safety, see below

Sma11 volume case 3501

Tetrode gage 5208

Extra grid stabilizes electron current 500360132
Ionization gages, hot cathode (cont'd)

Design (cont'd)

Tube geometry

Barkhausen effect avoided 3105

Gettering action, see Gettering action, ionization gages

Installation Location 520660129

Magnetron, see Ionization gage, magnetron

Operating techniques B571 60129 Degassing 60132

Performance 16012101536553785725581156064

Calibration 160121014826

Cathode, see a1so

Chemical reaction with gases $\mathrm{B} 491$

Decomposition of hydrocarbons 5333

Life 15015110

Review B571

Collector potential against output 4826

Contro1 of electron current 340837074103 42024607

Electrode geometry effect 54716064

Experiments to verify theory 5484

Gettering, see Gettering action above

Oscillating circuit, undesirable B491

Pressure fluctuations 5378

Ratio, positive ion to electron current, see

Vacuum factor below

Review B491 B571 4614

Rhenium filament 5723

Sensitivity, general

Data, various designs B491 B571 6095

Proportional to electrons per molecule B491 2402

Sensitivity ratio 240345036095

Fogel type gage 5266

Theory B491 B571 1902

Sensitivity, various gases 6095

Air, dry B571 51096064

Argon B471 B571 24033102450351096064

Carbon dioxide B571 5145

Carbon monoxide B571 2402

Coa1 gas 6063

Helium B491 B571 2402310245035109

Hydrogen B491 B571 24022403450351095145

Krypton B491 B571 4503

Mercury B491 B571 31024503

Neon B491 B571 240245036064

Nitrogen B491 B571 2402240345035109

51456064

0xygen B571 5109514560100

Propane-butane (calor gas) 6063

Water vapor B571

Xenon B491 B571 4503

Time lag

Data 2101

Theory 2101

Vacuum factor (positive ion to electron current ratio) 53505770

Oxide coated filament 5054

Pressure range, high $\mathrm{mm} \mathrm{Hg}$

$10_{-3}^{-4}, 46165109$

$10^{-3}, 16011902410256415770$

$2 \times 10-3,4826$

$5 \times 10-3,5269$

$10^{-2}, 5504$

$0.1,6064$

1,5718 
SUBJECT INDEX (cont'd)

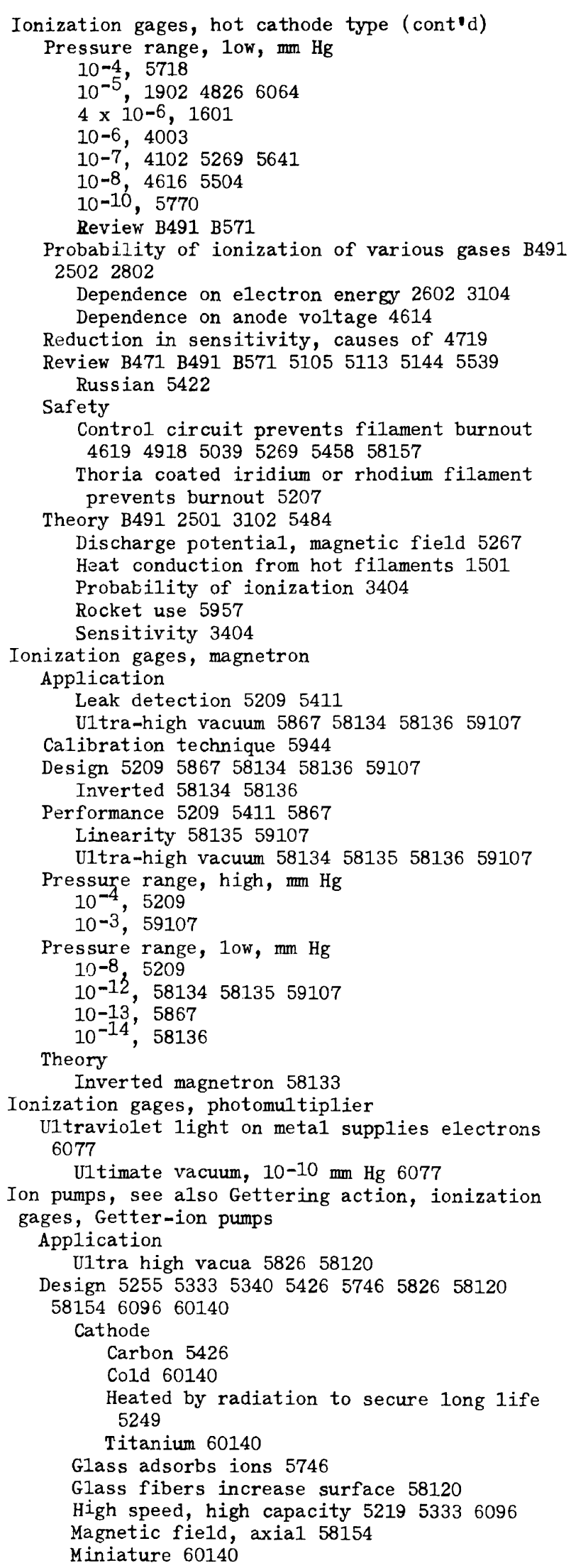

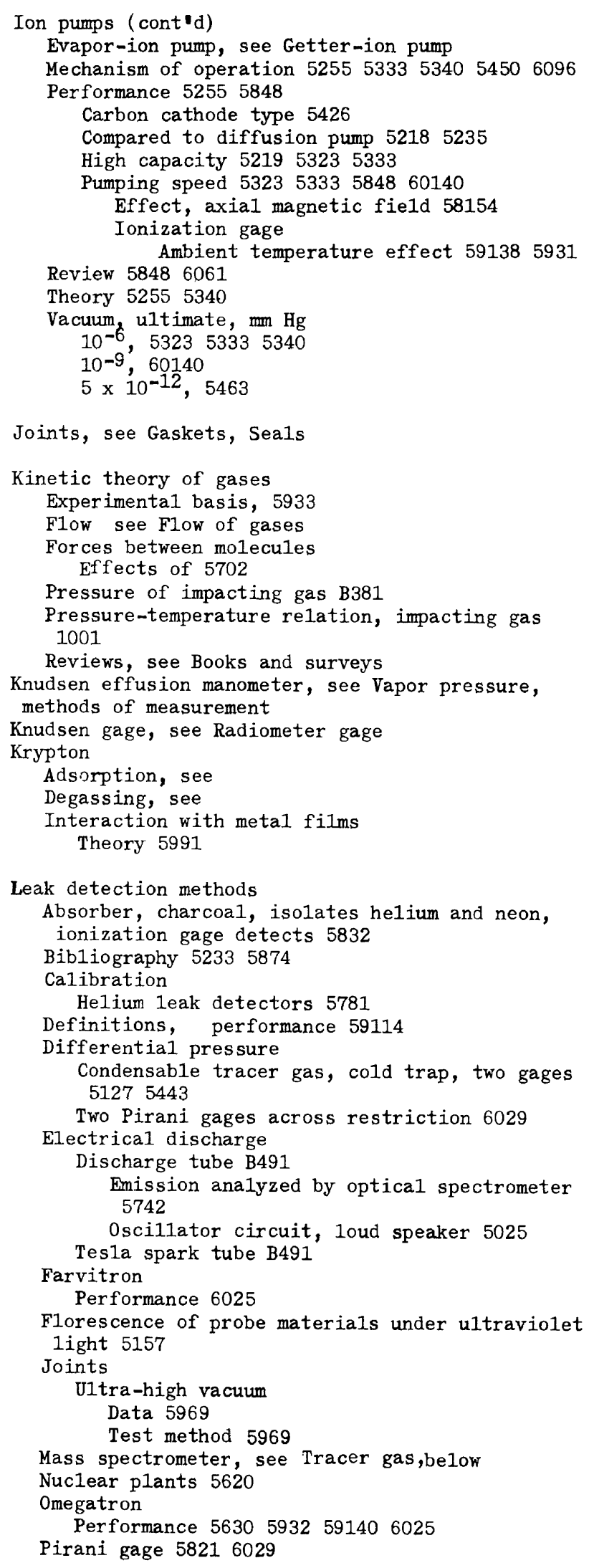


Leak detection methods (cont'd)

Positive ions for halogen compounds Diode 5850

P1atinum hot filament B491 4814

Probe gases, see Tracer gases, below

Review B491 B492 B551 47135536562058015850 English 59114

Merits of various vacuum gages 3504

Russian 5422

U1tra-high vacuum 5874

Rise in pressure

Evacuated space external to sealed container 5743

Ionization gage 59124

Audio frequency change-ether probe gas 4617

Palladium barrier, hydrogen 4505

Magic eye ionization gage

Halogens 4103

0xygen 4103

Pirani-loud speaker 3714

Sensitivity of detection B491 47135114

Diode 51145764

Ionization gage 5114

Magnetron 5411

Mass spectrometer, see

Omegatron 5630

Pirani 5114

Soluble dye 5620

Techniques 4713511458015963

Ionization gage, cold trap 5832

Magnetron ion gage 5411

Mass spectrometer 462051545912

Omegatron 59140

Spectrometer 5742

Theory B492 5801

Tracer gases

Air

Charcoa1 absorber leaves helium and neon, Argon

Ionization gage detector 5832

Mass spectrometer 580359140

Butane 51145127

Carbon dioxide 5002

Halogens

Ionization gage $\mathrm{B} 491$

Sensitive diode 5764

Helium

Electrodeless discharge analyzed by spectrometer 5742

Ionization gage B491

Mass spectrometer, see also

Aluminum foil trap, heavy ions 6075

Design 461850205648565756595912

Nier 46205020

Review B491 B493 5424553656205850

Techniques 5850

Hydrogen

Electrodeless discharge analyzed by spea trometer 5742

Hydrogen-palladium method, survey 5233

Ionization gage B491 5536

Cold cathode 5627

With palladium window 4505

Pressure rise while pumping 5329

Mass spectrometer 5154

Pirani B491 5233

Charcoa1 trap absorbs other gases 5507

Palladium barrier 523359103
Leak detection methods (cont'd)

Tracer gases (cont'd)

Low mass numbers

Omegatron 5630

Organic vapors

Ionization gage $\mathrm{B} 491$

Oxygen

Ionization gage B491

Thoriated tungsten filament 60100

Tungsten filament 40094506

U1traviolet light absorption, photoce11 5142

Leaks, controlled gas

Application

Corrosive gases 5352

Mass spectrometer 5644

Leak detection standard 5872

Bubble counter, gas 5129

Calibration methods 5706

Capillary with mercury slug 5660

Capillary tube

Flattened

Various gases 5658

Heated electrically 5608

Length adjustable

Needle 2601

P1atinum wire, heated 4812

Method of measurement 5658

Multiple 5833

Restriction in 5660

Slug of mercury, position controlled by piston 5825

Compression

Rubber disks with slot 51185706

Solder powder 5811

Differential expansion 5704

Glass tube, metal plug 5607

Two glass tubes control seal position 5352

Diffusion

Helium

Glass, see Diffusion, Helium

High silica 5872

Silica 5045587259152

Calibration by mass spectrometer 59152 Hydrogen

Nicke1 5444

Temperature contro1s leak 5734

Zirconium powder getters impurities 5734

Palladium, see Hydrogen, Palladium

Silicone rubber sheet 5738

Expansion, nicke1 cylinder, controls leak 5332

Graphs for computing flow 5602

Microdoser 5026

Misch metal

Desorbs hydrogen slow1y 6057

Needle valve

Solenoid, controlled 5831

Spring controlled 5324

Vibrated, amplitude controls leak 5326

Porcelain, porous, mercury leve1 contro1 5042

504753355736

Review B492 B551 B581 5704

Slide, glass, covers various holes 5325

Slit in glass tube

Adjustable 260135065037

Mercury covered 5706

Trapped in capillary by mercury column 5622 
SUBJECT INDEX (cont'd)

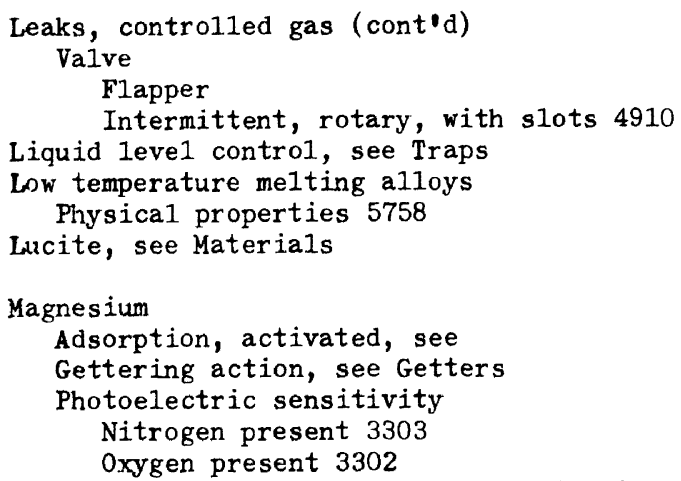




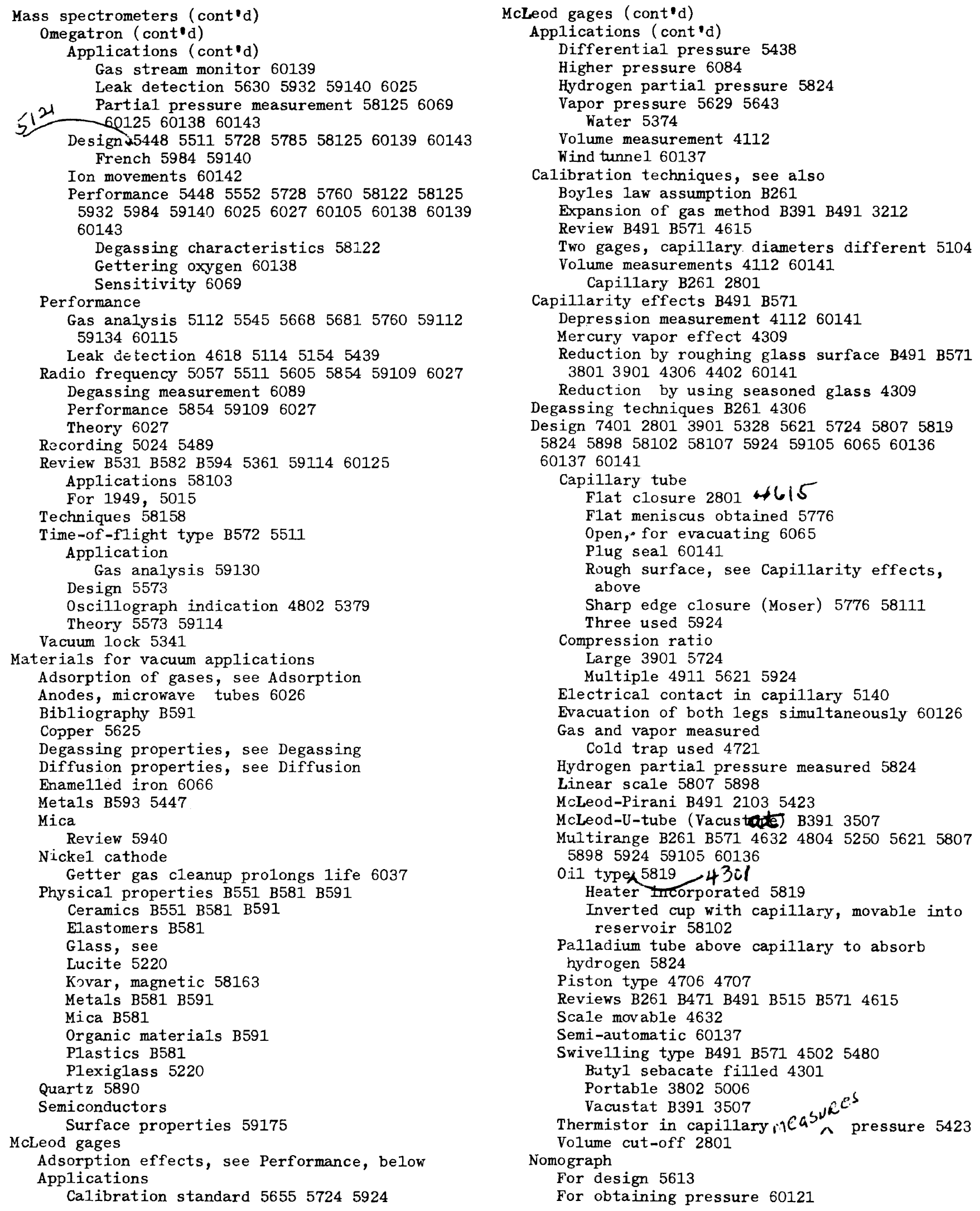

Mcleod gages (cont'd) 
SUBJECT INDEX (cont $d$ )

McLeod gages (cont'd)

Performance B491 461560137

Accuracy 3901470548045104532857245776

580759246011460141

Adsorption effects 60136

Ammonia B491 3505

Carbon dioxide B491 3505

Hydrocarbons B491 3505

Nitrogen 58107

Sulfur dioxide B491 3505

Boyles law departure 35055924

Capillary depression error 4112592460141

Condensable gases B91 4

Correction method 581115963

Cyclopropane 60114

Propane 60114

Water vapor B491 4502

Effect avoided by heating gage 4602

Multiple compression ratios detects 5963

Effect of cold trap 3211

Helium diffusion effect 60141

Hysteres is 5140

0i1 McLeod 5819

Oxidation of mercury B491 1305

Permanent gases B491 5924

Carbon dioxide 60114

Hydrogen 1305

Nitrogen 130560114

0xygen 1305

Pressure range, high, $\mathrm{mm} \mathrm{Hg}$

$10^{-2}, 390150065724$

$10^{-1}, 0 i 1,5819$

1,350753285423

3,4721

$3.5,5924$

Pressure range, low, $\mathrm{mm} \mathrm{Hg}$

$10-3,5328$

$10^{-4}, 13053507$

$10^{-5}, 390157245924$

$10^{-5}$, 0i1 5819

$2 \times 10^{-6}, 5006$

$3 \times 10^{-7}, 4306$

$10-7,5423$

$10^{-8}, 5776$

Review B491 B515 B571

Reviews, see also Books and surveys B261 B491 B515 B571 5105511351665479

Techniques of operation 39014306430960121 Measuring higher pressure 6084

Trapping condensable gases 5480

Theory B491 B515 B571 461548045924

Volume determination

Capillary tube B261 512460121

, Mean free path B381 B471 B491

Gases in oil vapors B491

Mechanical refrigeration system

For cold traps 5544

Mechanical pressure and vacuum gages, see also

Vapor pressure, methods of measurement Acoustical

Loud speaker, microphone measures received energy 5773

0scillating diaphragm, amplitude varies with vacuum 5663

Applications

Atmospheric pressure oscillations 40194111 45015490

U1trasonic 4703490250015784
Mechanical pressure and vacuum gages (cont'd)

Applications (cont'd)

Chemical reactions 5570

Affected by mercury 2904

Corrosive materials 56175840

Para and ortho hydrogen differential 5212

Physiology 470153075456

Blood pressure 5301

Standard 54015955

Vacuum 510253035562566357735810658110 581176081

Vapor pressure 36113701390656295959

Wind tunne1 48014803

Bellows element

Capacity pickup

Differential pressure 60104

Inductance pickup, bridge mechanically balanced 4801

Optical lever (East \& Kuhn) B571 4601 Performance 4601

Transformer, differential 501956175840

Two bellows, linear transformer Differential pressure 5840

Vibrating disk, fixed, electrical capacity changes 5828

Bourdon tube gages, see

Centrifugal manometer

Air 54015955

Deadweight disk valve

Force balanced electrica11y B491 3611

Force balanced by tilt B491 37013906

Diaphragm element, corrugated

Bery11ium copper 5337

Capsule, optical lever 5722

Copper 5302

Diaphragm capsule, nesting 4803

Diaphragm nesting 53035305

Nul1 type

Secondary measure pressure restores zero deflection 5629

Precision screw measures restoring motion 5490

Silver 5302

Transducer

Electrical capacity $\mathrm{B} 571$

Capacitance bridge 5101

Frequency measured 53025337

Resonant bridge carrier system 5305

Inductance 5103

Mutua1 51025303

Strain gage, unbonded 4803

Diaphragm element, flat

Electrostatic force restores to zero 5562

56165810658110

Material

Aluminum 52125784

Copper B491 0902

Dura1 4019

G1ass B491 290230073904

Mica 3007

P1atinum-iridium 2904

Quartz 4008

Stainless steel 55705811760112

Performance 390440084701500552125327

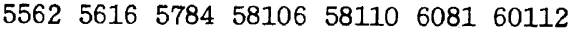

Dynamic 500552715570578460112

Error due to adsorbed dipole gases in electrical capacity type 5677

Theory 5677 


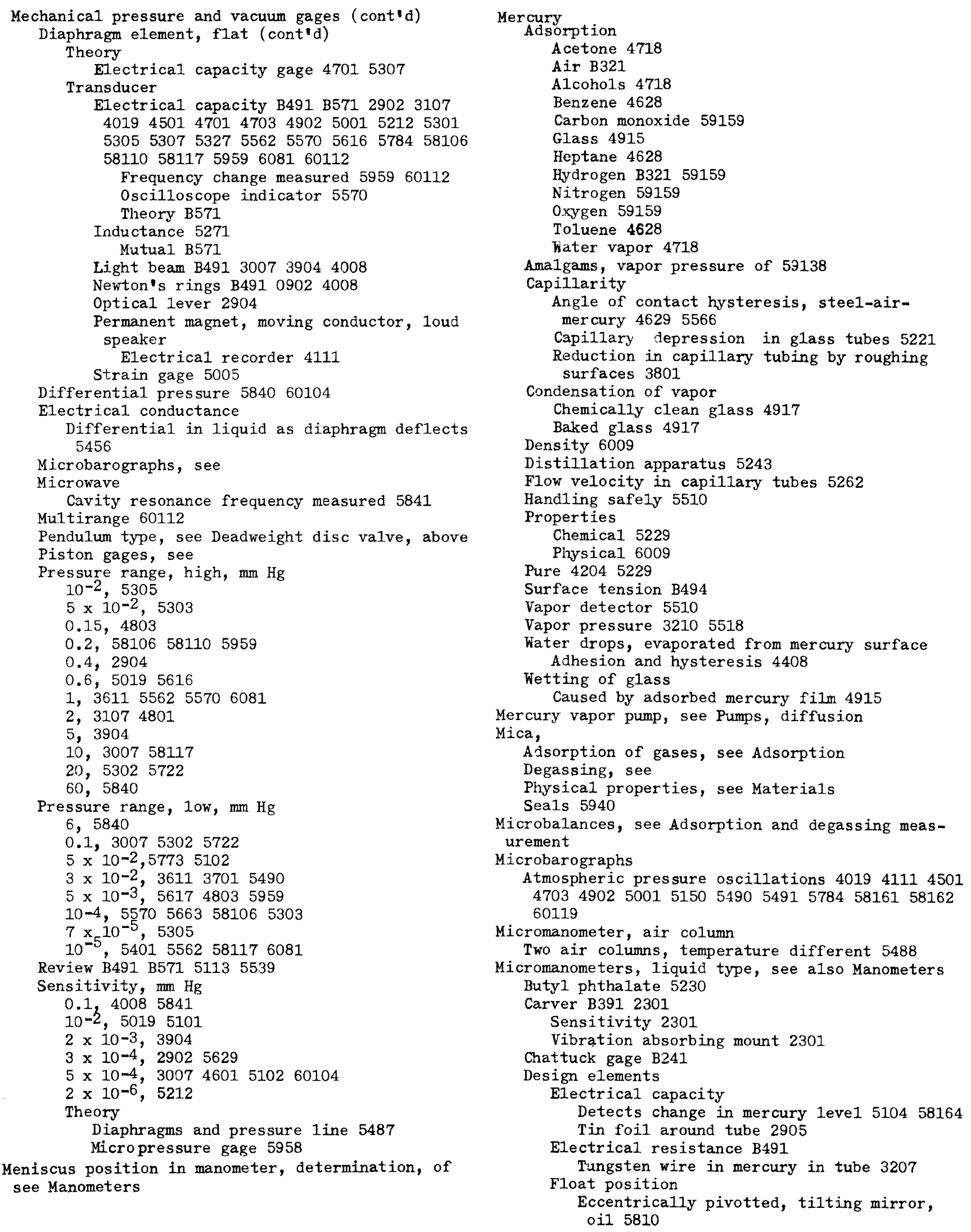


SUBJECT INDEX (cont'd)

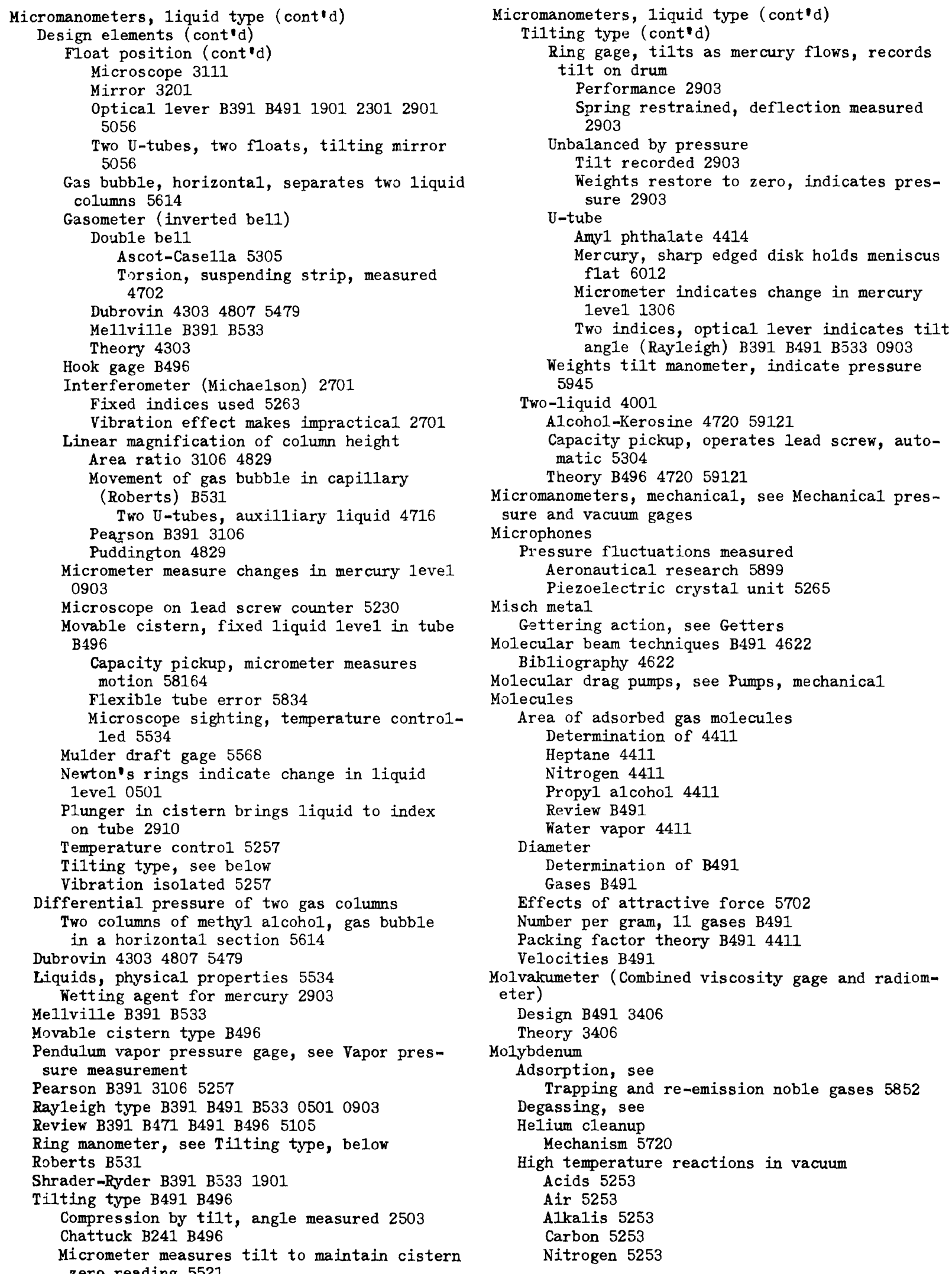


Mo1ybdenum (cont'd)

Surface cleaning techniques 32064007

Work function 3206

Mordenite, see Zeolites

Motor, for vacuum use 5017

Neon

Adsorption, see

Degassing, see

Neoprene, see Rubbers

Nicke1

Adsorption of gases, see

Cathode 1 ife prolonged by getter gas clean-up 6037

Degassing, see

Diffusion of carbon 5260

Diffusion of gases, see

Single crysta1

Cleaning surface techniques 40075880

Solubility of

Carbon 5260

Trapping and re-emission, noble gases 58525875

Nitrogen

Adsorption, see

Area, adsorbed molecules 4411

Degassing, see

Diffusion, see

Gettered, see Gettering action, ionization

gages, Getters

Origin in vacuum systems 5308

Solubility, see Solubility of gases

Sticking probability, see also

Metals 5313

Onegatron, see Mass spectrometer

Orifices

Conductance, see Flow of gases

Outgassing, see Degassing

Oven, infrared 5780

0xide films, formation and stability, see also

Adsorption, activated 4206

Iron, chrome iron 4206

Mechanism 4722

Radiation effect

Aluminum 4924

Stainless stee1 4206

Theory 47224924

Tungsten 4821

0xides, refractory, reaction with metals at high temperature 5349

oxygen

Activated by hot filament 401860138

Adsorption, see

Adsorption, activated, see

Degassing, see

Dissociation, electron impact 3209

Gettered by, see Gettering action, ionization gages, Getters

Origin in vacuum systems 5308

Sticking probability, see

0xygen partial pressure gage

Magnetic susceptability of oxygen (Pauling)

Design 4631

Performance 4631

Temperature effect 4631

Pressure range 4631

Palladium, see Hydrogen also

Deuterium adsorption 3715
Palladium ( cont d)

Hydrogen adsorption 59123

Hydrogen diffusion

Applications 5532

Data $5363 \quad 5475553258916076 \quad 6089$

Controlled leak 6085

Temperature effect 547558916076

Theory 536358916076

Surface reactions, various gages 5993

Palladium-silver alloys

Adsorption of hydrogen 6094

Pauling gage, see 0xygen partial pressure gage

Penning gage, see Ionization gage, cold cathode

Perbunan, see Rubbers

Permeability of gases into solids, see Diffusion

of gases through solids, Porosity

Permeation, see also Diffusion

Definition, difference from diffusion 5473

Review 5473

Persorption in zeolites B491

Philips vacuum gage, see Ionization gage, cold cathode

Photomultiplier ionization gage, see Ionization gages, photomultiplier

Piezoelectric gages

Barium titanate

Aerodynamic use, sensitivity 12 dynes $/ \mathrm{cm}^{2}$ 5851

For weak shock waves 5838

Quartz

Damping of oscillation indicates pressure Range, $0.1-760 \mathrm{~mm} \mathrm{Hg} 5930$

Pirani gages

Advantages and disadvantages B.491 5251

Applications

Chemical 5241

Corrosive gases 59101

Leak detection 5004591036029

Van der Graff accelerator 6029

Wind tunnel 561560135 Sipersonic 4901

Bimetal gages, see Expansion gages, thermal

Calibration techniques, see

Combined Pirani-thermocouple gage 4605

Combined Pirani-ionization gage 5365

Design 48284903515852515306536553735437

$\begin{array}{lllllll}5486 & 550156015711 & 5713 & 5753 & 5807 & 5827 & 59101\end{array}$ 5910360135

Control circuits B571

Feedback to hold filament temperature constant 5241550157115713

Magnetic amplifier 5753

Power supply 480548065008

Safety from high pressure damage 46054805 Thyratrons-re1ay 5007

Cyclic volume changes 50025201

Convection a maximum 5714

Differential, two gages, same Wheatstone

bridge 5004

Electronic amplification

Controls linearity of output 5437

Filament or sensitive element 4704

Bimeta1 strip 3613

GLass covered 500859101

Helical 47045373

Liquid in glass tube 2504

Long wire to increase range 5601

Mo1ybdenum B571

Nicke1 B.191 3101 
Pirani gages (cont'd)

Design (cont'd)

Filament or sensitive element (cont'd)

Piatinum B571 06011103520252515902

Quartz coated 5403

Review B491 B571

Spring tension supported 3810

Thermistor, see below

Tungsten B.491 B571 460352025251

Indication, mode of

Bimetal strip deflection 3613

Electrical output for control purposes 4605

Galvanometer, output first amplified 3905

Linear expansion of filament measured

3305

Loud speaker 3714

Oscilloscope 5619

Thermocouple measures filament temperature 060236123703

Wheatstone bridge, see below

Linearity achieved by electrical compensa-

tion 5373

Miniature 60135

Palladium barrier 59103

Pirani effect, thermionic tube

Emission current he1d constant 5028

Pressure range

High pressure 5241

Multiple 5807

Various 5202

Recorder

Multipoint (16) potentiometer 4901

Records Wheatstone bridge current 5713

Sensitivity, maximum B491 B571 3101

Sma11 size 5615

Two grain-of-wheat lamps 5306

Temperature compensation B491 B571 60135 Duplicate Pirani 11032805361338104923 5306542555015615

Thermistor type, see below

Vacuum range extended by gas compression 58114

Vo1tage compensation $B 571$

Wa11 temperature control B491 280533063612 36135373

Wheatstone bridge

Bálanced $1103 \quad 3810480654865615 \quad 5827$ Automatic 55015713

Constant filament current 06012805

Constant filament temperature B571 0601 21025827

Constant vo1tage B571 0601

Review B491 B571

Unbalanced 060131013306470448054923 530657115934

Zero shift indicator 4923

Expansion gages, therma1, see

Gettering

0xygen by barium 5162

Performance 2805490352155365540354865601 5753

Accommodation coefficient, see

Filament

Ageing B571

Constant current vs constant temperature 4825

End 1osses B571
Pirani gages (cont'd)

Performance (cont'd)

Filament (cont'd)

Diameter B491 B571 33045151

Length B491 B571 4903

Temperature B491 B571 310133045202

Wa11 distance 4825

Linearity 537354375501

Pressure range

Distance, filament to wall effect 4603 4704

Sensitivity, various gases B491 B571 5156

Air 4307480649034923

Argon 4806525153735934

Carbon dioxide 48064903

He1ium 490352515934

Hydrogen $43074806 \quad 4903 \quad 4923 \quad 5251$

Krypton 52515834

Mercury 4923

Neon 525153735934

Nitrogen 5251

Review B.491 B571 4704

Xenon 52515934

Stability

Corrosive gages 59101

Thermistor gage, see below

Wa11 temperature

Contro11ed 31013612

Effect 280533045202

Pressure range, high, $\mathrm{mm} \mathrm{Hg}$

$6 \times 10^{-3}, 1103$

$10^{-3}, 28053905$

$0.15,2102$

$0.10,370348054923$

5,52025403

10, 48065306536556015615

50,5711

160,4603

760,5714

1000,36125753

Review B471 B491 B571

Thermistor type, see Thermistor, below

Pressure range, 1ow, $\mathrm{mm} \mathrm{Hg}$

$10^{-1}, 53065615$

$2 \times 10-2,4603$

$10^{-3}, 21023305 \quad 3612536554035711$

$10^{-4}, 3703$

$10^{-5}, 110339054923500254965902$

$4 \times 10-6,2805$

$10^{-6}, 3306$

$10-8,3101$

Review B471 B491 B571 47044903511351445539

Theory B391 B491 B571 2102490351565934

Ambient temperature effect $B 571$

Bimetal strip type 3613

Filament

Length and diameter 31013304

Temperature 32023304

Heat conduction along filament B571 17013202 4704

Radiation losses 32024704

Sensitivity 490351565486

Thermistor gage, see below

Thermistor type

Design B491 4307 462654255520 561958119

59025964596760118

Recorder

Voltage balance 5902 
Pirani gages (cont'd)

Thermistor type (cont'd)

Design (cont'd)

Recorder (cont'd)

Voltage unbalanced 60119

Temperature compensated 5967

Ventilated above $10 \mathrm{~mm} \mathrm{Hg} 5730$

Wheatstone bridge 5425

Balanced 5520

Unbalanced 60118

Performance 4307552056195730581195964

596760118

Duplicate element for temperature compensation 58119

Time lag 578360118

Wa11 temperature effect 5783

Pressure range, high, $\mathrm{mm}$

1, 581195967

10,5425573060118

20,5964

760,43075902

Pressure range, low, m $\mathrm{Hg}$

$10^{-2}, 596460118$

$5 \times 10^{-3}, 5520$

$10^{-3}, 5425$

$10^{-6}, 43075619581195967$

Theory 581195964

Wa11 temperature effect 5783

Thermocouple vacuum gage, see

Upper air application 5002

Piston gage, micropressures

Air Lubricated

Tilting 5910

Compression of gas 47064707

Mica, quartz helical spring 5518

Torsion balance 35103511

Sensitivity, $10^{-4} \mathrm{~mm} \mathrm{Hg}$

Pitot tube

Calibration, free molecular flow

Rotating arm 58100

Plastics, see Materials

P1exiglass, see Materials

Platinum

Adsorption, see also

Hydrogen 29063402

Oxygen 1802

Degassing, see

Ion emission, bombarded with inert ions 5917

Surface contamination, hot filament 3402

Porosity, see also Leaks, controlled gas

Analcite crystal

Ten gases 51465147

Theory 51465147

Charcoal

Argon B583

He1ium B583

Methane B583

Neon B583

Earthenware plate, unglazed 3716

Evaporated films, see Thin films

Glass beads \& fibers 4013

Glass woo 1

Theory 5051

Mechanism B583

Porous diaphragms

Conductance data B491 3716

Theory, flow rate $\mathrm{B} 491$

Silica gels, see
Porosity (cont'd)

Sintered glass

Theory 4627

Various gases 4627

Symposium B583

Pressure controllers

Barostat

Barometer, electrical contact, relay, solenoid 5027

Bellows, evacuated, weights 6009

Contro1 circuit, magnetic amplifier, vacuum gage 5858

Gasometer (be11), balanced beam, controls air supply to gas flame

Photoce11, feedback to air valve 4919

Gasometer (Cartesian diver)

Be11 position controls light beam into photoce11 5160

Bell position controls valve 513657755972

Ionization gage

Electronic circuit controls safety valve 58157

Gage bucks set voltage, differential caused to operate valve 6078

Manometer

U-tube, photoce11s, contro1s leak

Octoil-s 5529

Silicone 703,5808

Pirani gage

Output, through solenoid, controls gas leak 5716

Output controls valves and pump operation 5133

Review 5571

Thermocouple gage-electronic circuit controls

safety valve 58157

Vacuum pump operation

Electrical circuit, thermocouple gage 5559

Pneumatic controller, alphatron gage, controlm led leak 5855

Semi-automatic 5916

Pressure measurement

Acoustical vacuum gage, see Mechanical pressure and vacuum gages

Air column manometer, see Micromanometers, air column

Alphatron gage, see Radioactive ionization gages

Atmospheric pressure oscillations 401941114501 470349025150549054915789

Barometers, see

Bibliographies, see

Bimetal gages, see Expansion gages, thermal

Bourdon gages, see

Bourdon tubes, see

Centrifuga1 manometers, see Mechanical pressure and vacuum gages

Convection manometer, see

Deadweight disc valve, see Mechanical pressure and vacuum gages

Diaphragm gages, see Mechanical pressure and vacuum gages

Diaphragms, see

Differential electrical conductance manometer 5456

Differential pressures at high absolute pressure 36016008

Dynamic, see Dynamic pressure measurement 
Pressure measurement (cont'd)

Effusion method, vapor pressure, see Vapor pressure, methods of measurement

Electrical discharge in gases varies with pressure, see Electrical discharge in gases

Electrical mass filter gage, see Mass spectrometers

Evaporation gage 5105

Expansion gages, therma1, see

Field emission phenomena, see Field emission

microscope, Surface reaction phenomena

Flowmeter, vapor pressure, see Flowmeters

Force-pressure balances, see

Gasometer, see Micromanometers, 1iquid type

Gravity disc valve, vapor pressure, see Vapor

pressure, methods of measurement

Ionization gages, see

Bayard-Alpert

Cold cathode

Hot cathode

Magnetron

Photomultiplier

Knudsen gages, see Radiometer gages

McLeod gages, see

Manometers, see

Magnetic susceptibility of oxygen, see 0xygen partial pressure gage

Mass spectrometers, see

Mechanical pressure and vacuum gages, see

Microbarographs, see

Micromanometers, see

Microphones, see

Microwave 5841

Piezoelectric gages, see

Pirani gages, see

Piston gages, see

Pressure balance, automatic, constant volume system 5569

Radiometer gages, see

Radioactive ionization gages, see

Rate of change, see Rate of change of pressure measurement

Reviews, vacuum and pressure measurement, see Books and surveys

Ring manometers, see

Surface reaction techniques, see

Thermistor gages, see Pirani gages

Thermocouple gages, see

Torque-pressure balances, see

Upper atmosphere B532 52015402576957865787 Ionization gage 5769

Response time in rockets 5623

Theory, rockets 5769

Vacuum measurement, general, see

Vapor pressure measurement, vacuum range, see

Viscosity gages, see

Work function of tungsten, see Tungsten

Zirconium reactivity, high vacuum

$\mathrm{Gain}$ in weight indicates furnace pressure 4920

Pressure range of vacuum gages, see also various

gage headings Chart B491 B581

Pressure regulators, see Pressure controllers

Pressure simulation, outer space 59154 Design 59142
Pumping speed, see also Getter-ion pumps, Pumps, diffusion

Back diffusion or streaming, see Diffusion pumps-

Data on pumps B581 5848

Diffusion pumps

Mercury 48205936

Large 5359

0 i1 4820522859156

Dependence on heat input 5949

Evapor-ion pump 54515550

Rotary pumps 5036

Cenco 5661

Fluctuations, cause of

0 i1 vapor pump 5432

Measurement B491 B506 B512 B551 503659495975 598259147

Circulatory method B491 4816

Constant leak, position of orifice varied Pressure measured at two orifice positions 59147

Constant pressure method B491 B551 5661

Constant volume method B491 B551 5661

Dayton's techniques 48165810958116

Mass spectrometer used 5550

Metered multiple leak method 5765

Oatley method 5445560958109

Pressure drop across conductance 54295445

5609586158128

Review B491 581095982

Sources of error 4816

Test dome size effect 581165982

Test gas selection 4816

Theory B382 B491 58116581206060

U1tra high vacuum 546358120

Pumping down time 5404

Theory 586059160

Rate of exhaust, free molecular flow Orifices

Tubes Theory B491 5823

Review Theory B491 5823

Methods of measurement 58109

Standard method 58155

Theory 5810958116581206002

Adsorption effect 594759153

Gas velocities in pump jets 5895

Pressure-time 586059475915359160

Pump oils

Additives to prevent decomposition 5414

Adsorbed on glass and meta1 B491

Apiezon A

Molecular weight 5213

Vapor pressure B491 B581

Apiezon B

Molecular weight 5213

Vapor pressure B491 B581 52285508

Apiezon C

Molecular weight 52135783

Vapor pressure B581 52285788

Apiezon E

Molecular weight 5788

Vapor pressure 5788

Apiezon G

Vapor pressure 5228

Arochlors

Vapor pressure B491 B581 
Pump oils (cont'd)

Breakdown, electron impact, see Electronic impact phenomena

Degassing data B581

i-Diamy 1 phthalate (Amoil)

Physical properties B491

Vapor pressure B491 B581

i-Diamy1 sebacate (Amoil-s)

Physical properties B491

Vapor pressure B491 B581

n-Dibuty1 sebacate

Physical properties B491

Vapor pressure B491

n-Dioctyl hexa hydro phthalate

Decomposition rate 5417

Di-2-ethy1 hexy1 phthalate (0ctoil)

Molecular weight 52135788

Physical properties B491

Vapor pressure B491 B581 36095788

Di-2-ethy1 hexy1 sebacate (0ctoil-s)

Molerular weight 52135788

Physical properties B491

Vapor pressure B491 B581 55085788

Diffeln

Vapor pressure B581

Di-n-nony1 phthalate

Vapor pressure B581 3609

Di-n-octy1 phthalate

Molecular weight 5788

Vapor pressure B581 36095788

Di-3-5-5-tri methyl hexyl phthalate (Narcoil)

Molecular weight 5788

Vapor pressure B581 52285783

Evaporation, see

Litton oi1

Vapor pressure B491 B581

Mean free path of gases in oil vapors B491

M-phenoxy phenoxy (m-bio-benzene)

U1timate vacuum 60116

Vapor pressure 60116

Physical properties 4819

Purity

n-dibuty 1 phthalate 3610

Review B491 B581 441448195228

Silicones

Decomposition rate DC703, 54175508

Molecular weight DC702, 5213; DC703, 5788

Physical properties B491 53545476

Vapor pressure DC703, 55085788

Vapor pressure B491 B581 5228

Stability on heating B491

Test methods 3610

U1timate vacuum

Various oils B491 48195228

Vacuum distillation 4414522352245225

Pumps

Vapor pressure B491 BD̄81 36095508

Ballast, gas, see Pumps, mechanical

Cryogenic, see Pumps, cryogenic

Diffusion, see Pumps, diffusion

Ejector, see Pumps, ejector

Evapor-ion, see Getter-ion pumps

Getter-ion pumps, see

Getters, see

Ion pump, see

Mechanical, see Pumps, mechanical

Mercury vapor, see Pumps, diffusion

Molecular drag, see Pumps, mechanical

Piston, see Pumps, mechanical
Pumps (cont'd)

Pumping speed, see

Reviews, see Books and surveys, Pumps, diffusion

Roots type, see Pumps, mechanical

Rotary, vane type, see Pumps, mechanical

Traps, see

Venturi, see Pumps, ejector

Pumps, cryogenic, see also Traps

Application

Vacuum wind tunne1 5847

Helium, liquid 536755535836586759117

U1timate vacuum, $10-9 \mathrm{~mm} \mathrm{Hg} 59117$

Hydrogen, liquid

Continuous1y produced 5847

Nitrogen, liquid 5867

Pumps, diffusion

Application

Accelerators 5935

Coating conductors and dielectrics 5656

Differential multiple pumping 5757

U1tra high vacuum 58645814159815914660116

Backstreaming $4820522852345413 \quad 58125935$

Causes 5433

Contro1 5433

Detection B572

Measurement methods 5433

Prevented by baffles 51.1160107

Reduction by pump design 52345935

Theory 5038

Vacuum limitation 5980

Baffles, refrigerated 5815959146

Freon vapor, cold cycle

Closed and open circuit 5611

Performance 5611

Gaede

Design B491

Performance B491

Theory B491

Glycerol vapor

Performance 4813

Langmuir condensation pumps

Designs B491

Performance B491

Mechanism of operation 54275512

Mercury, vapor

Design

Chemical absorber B491

Factors to obtain maximum pumping speed 54365515

High speed 462153595549

Mercury trap B491

Refrigerating means $B 491$

Gaede B491

G1.ass 5515

Langmuir B491

Mechanism of operation B491 46215567

Mu1tistage B491

Nozzle design B491

Performance 46214816482053595515

High speed 5549

U1timate vacuum 581415936

U1tra-high vacuum 581415936

Theory, see below

0i1 vapor B382 B491 29095354

Design B491 54205654581455935591446072 60116

Jet and baffle $B 491$

Baffles 60107

Baffles refrigerated 59146 
SUBJECT INDEX (cont $d$ )
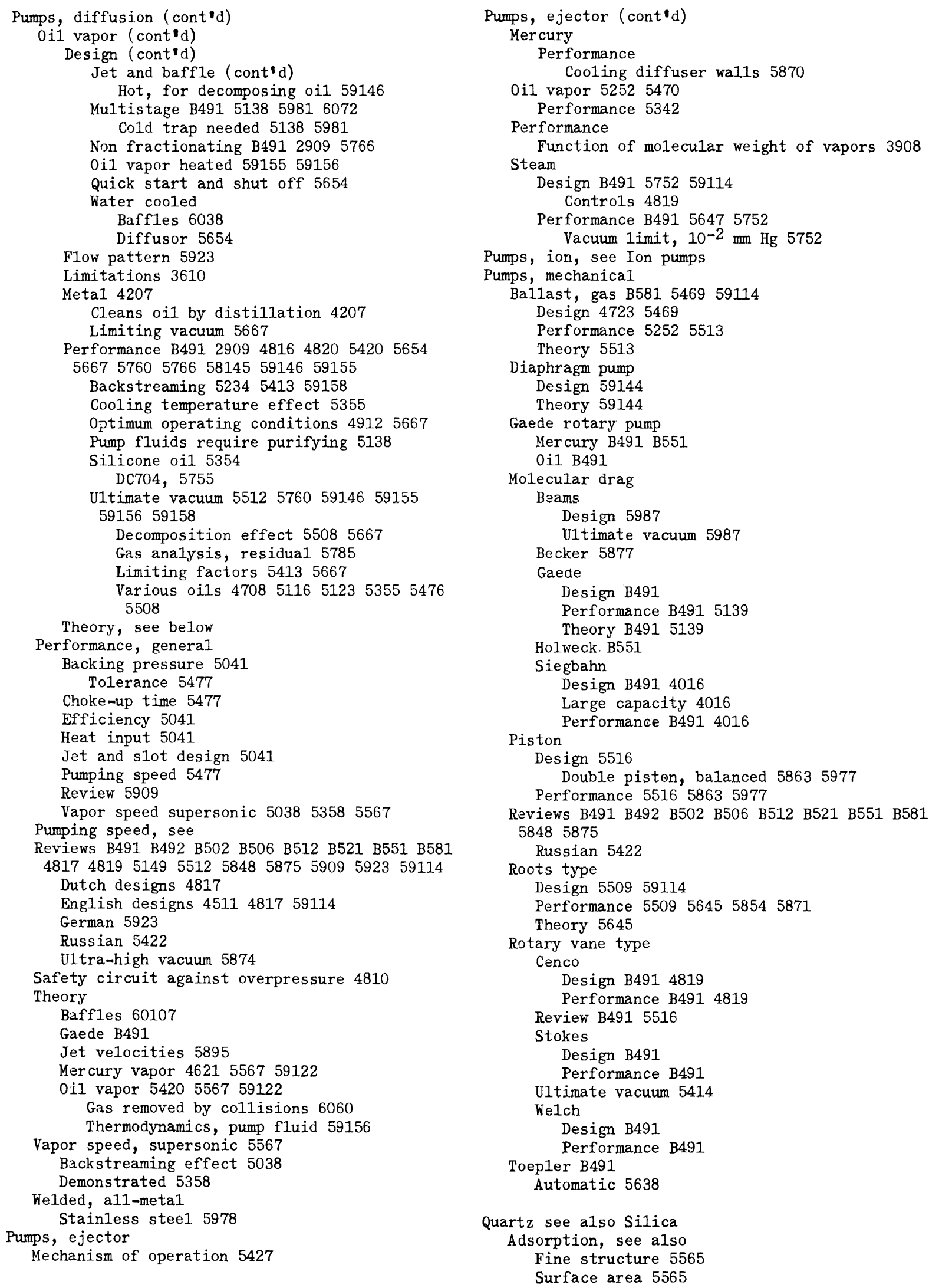
Quartz (cont'd)

Properties

Review B581 B591

Vacuum applications 5890

Radioactive ionization gages

Alphatron $4608 \quad 460948285402566458118$

Applications

Rockets 5911

Upper air 590159148

Vapor pressure 56,40

Wind tunne1 59150

Design B491 B571 460846094828511154025640

591159150

Improved A1phatron 5664

Mu1tipoint measurement system 59150

Permits heating 5640

Radioactive material

Polonium 5111

Radium 226, 59150

Tritium $5818590159148 \quad 581 / 8$

Performance B491 4608 4009 5664581185901

5914859150

Sensitivity

A ir 4608

Argon 4608

Carbon dioxide 4608

Helium 4608

Hydrogen 4608

Neon 4608

Time response 5664

Pressure range, high, mm $\mathrm{Hg}$

$0.75,5911$

$7.5,5402$

10,4608

30,59150

100,5111

200,59148

Pressure range, 10w, mm Hg

$10^{-1}, 511159150$

$4 \times 10^{-2}, 54025901$

$10^{-3}, 46085911$

$10^{-5}, 59148$

Review B491 5113

Theory 5664

Radiometer gages

Accommodation coefficient, see

Applications

Calibration standard

$$
\text { Ionization gages } 5145
$$

Gas kinetic cross section 5574

Molecular weight determined 5560

Vapor pressure measurement 5946

Bibliography 5125

Calibration, see also Calibration methods

Capillary leak method 3709

Expansion of gas method 14034909

Design 5034512553175946

Damping of vanes

E1ectromagnetic 140235045961

Magnetic 5227

Du Mond-Picke1s 35044611

Fiber suspensions 371351255126

Force balanced by gravity

Vane, suspended

Instrument rotated to vane zero 4304

Lamp and scale 5227

Microscope 3709380739104907
Radiometer gages (cont'd)

Design (cont'd)

Heats gas periodically, strike vane in resonance

Measures amplitude of vane vibration 6087

Static charges

Glass envelope coated with silver 3910

Vane grounded 49095560

Temperature control

Electrical 4909

Water bath 39104827

Temperature of heated strip by measuring

resistance 1402

Torque balanced

Beam balance 4824

Electromagnetic B391 B491 190432043205

37104407

Electrostatic 3006

Automatic, photoce11 feedback 5210

Torque measured

Torsion wire 5321

Microscope 5961

Mirror and scale 1002130314021801

3504440746115946

Vanes around a cylinder 4407

Viscosity-radiometer gages combined

Vane in resonant vibration, amplitude measured 5560

Performance 370939104827521053175961

Adsorption effects 4711

Envelope diameter effect 3910

Radiometric force

Effect, design and size of elements 2804 3503

Gas composition effect, see Sensitivity, below

High pressure B571

Pressure at maximum, various gases B571 2804

Pressure relation 44075893

Review B491 B571

Sensitivity, various gases B571 28043204 3910

Air 4304

Argon 3710

Butane 4909

Deuterium 3710

Helium 3710380640054303

Hydrogen $37103806 \quad 400543044909$

Methane 4909

Nitrogen 3710380640054909

oxygen 37104909

Temperature difference effect 3910

Time constant B57I

Du Mond-Pickels gage 4610

Pressure-force data 3002

Pressure range, high, mm $\mathrm{Hg}$

$10^{-4}, 35043709$

$5 \times 10^{-4}, 5961$

$10^{-3}, 32043807490952275946$

$10^{-2}, 503451255317$

$0.15,5321$

1,4304

10,5210

Pressure range, low, m $\mathrm{Hg}$

$10^{-5}, 49095227$

$10^{-6}, 350437093807503453175946$

$8 \times 10^{-7}, 1801$ 
SUBJECT INDEX (cont'd)

Radiometer gages (cont $\mathrm{d}$ )

Pressure range, 1ow, $\mathrm{mm} \mathrm{Hg}$ (cont d)

$10^{-7}, 430453175961$

$10-8,440751255210$

Review B471 B491 B571

Review B261 B471 B491 B571 510551135125

Theory B261 B491 B571 5125

Knudsen

Departures from 3710

Pressure-force relation 1903240124073204

380744064710

Pressure-temperature relation 100110021905 3205

Time lag 4610

Radon, clean-up 5636

Rate of change of pressure measurement

Capillary tube restriction

Barograph 5381

U-tube manometer, float, recorder 58161

Microbarographs, see

Rayleigh gage, see Micromanometers, liquid type

Rectifiers, semiconductor B542

Refractory oxides, reaction with metals at high temperature 5349

Residual gases, see also Adsorption and degassing measurement

Amalgamated meta1s 59138

E1ectron tubes 591396019602060105

Pressure-measuring method 6018

Glass-metal system 59139

Investigation, vacuum systems 6021 Picture tubes 60226023

Ionization gage 602860133

Mass spectrometer 60133

Metal filaments, interaction with 6031

U1tra-high vacuum system 591576015

Resonance manometer 5560

Ring manometer

Differential pressures at high absolute pressures 3601

Micromanometer 2903

Theory 4101

Rubbers

Cleaning techniques Neophrene 5953

Degassing

Buna 5032

Buty1 59100

Crepe 59100

Joints 58108

0 -rings 5032

Neoprene 58045814

Perbunan 59100

Rate 5768

Red vacuum tubing 58045869

Review 59153

Silicone 525658045869

Techniques 5953

Vulcanized 59100

Diffusion through

Neoprene

Hydrogen 59153

Nitrogen 59153

0xygen 59153

Perbunan

Helium 59153

Hydrogen 59153

Nitrogen 59153
Rubbers (cont'd)

Diffusion through (contd)

Rubber

Carbon dioxide 59153

He1ium 526159153

Hydrogen 526159153

Nitrogen 526159153

Oxygen 59153

Vapor pressure 5666

Safety against overpressure, see Diffusion pumps,

Ionization gages, hot cathode, Pressure contro1-

lers

Seals, vacuum, see also Gaskets

Brazing high nickel alloys 5258

Electrical leads

Cement insulation 5231

Glass to meta1, demountable 5128

Kovar-glass-kovar-aluminum gasket 5818

Multiple, molybdenum strips between two silica tubes 5985

Neoprene gasket 5845

0 -ring, demountable 5844

Sapphire rod to copper, low temperature 5834 Techniques 5454

Tungsten wire through glass 5813

Epoxy resin

Degassing, see, under Resin

Low temperature operation 5943

Performance 5731

Techniques 6097

Gaskets, see

Glass to glass

Lubricated, ground joint, refrigerated 5907

G.lass to metal, permanent

Coatings to increase electrical conductivity 5348

Design 56695862

Low temperature 5903

Dumet to glass in vacuum tubes 59168

Kovar, magnetic properties 58163

Nicke1-chromium-iron alloy 5050

Review B521 53485897

Silver paint 5022

Techniques 5348

Theory 5862

Knife edge type 554359163

Applications 5543

U1tra-high vacuum 545759163

Gaskets

Aluminum 511954315442

Copper 543154575537574160105

Nicke1 5431

Knife

Ceramics 5431

Glass 5431

Metals 5431

Quartz 5431

Sapphire 5431

Stee1 ring, double knife 5741

Tube wa11 into saw tooth on base 5701

Two tubes 5457

Leakage rate 5537

Low melting point solids

Gallium, indium and tin alloy Seal by surface tension of 1iquid 5758 59163 
Seals ( cont'd)

Low melting point solids (cont d)

Indium 5/142 553058158

Wire gasket 5733

Mercury 5442

Low temperature use 58160

Metal to meta1 5669

0i1 seal 4305

Performance

U1tra high vacuum 5969

Rectilinear motion in vacuum system Bellows seal 5531

Requirements 5543

Review B581 5533

Russian 54225927

U1tra-high vacuum 58745915

Retatable continuous1y 5222

Ball and socket 59164

Stee 1 washers, compressed 5829

Two sea1s, vacuum between 5238

sliding

Pipe flanges, 0-rings 5135

Windows

Calcium fluoride

Glass 5837

Electron permeable

Nickel screen, Bentonite clay filler 5839

Mica 5744

Differential expansion, high temperature use 5835

Solder-glass seals to titanium

Bakeable, ultra vacuum 6010

Polyethelene gasket

For 1iquid helium temperature 5950

Radial compression seal, glass, ceramic, sapphire windows 59167

Sapphire 59164

Silica, see also Quartz

Adsorption of gases, see Adsorption

Organic vapors 3509

Fibers 3713

Coated 3713

Silica gel absorber

Alcohol vapor 2508

Benzene vapor 2508

Butane 2505

Theory 2505

Carbon dioxide 2507

Carbon tetrachloride 2508

Hysteresis loop 4106

Hydrocarbon vapors (15) 5998

Hysteresis B491

Nitrous oxide 2507

Review B491

Structure B583

Theory 2507250838115998

Water vapor 2508

Silicon

Hysteresis 10op 4106

Adsorption, see

Borosilicate glass causes boron deposit 6099

Cleanliness of crystal surface 58805908

Degassing, see

Work function, crysta1s 5879

Silicone rubber, see Rubbers

Solubility of gases in solids

Elastomers

Argon B522
Solubility of gases in solids (cont'd)

Elastomers (cont'd)

Hydrogen B522

Theory B522

Nitrogen B522

Glass

Helium 5434

Metals

Carbon monoxide B491

Hydrogen B491 B522

Nitrogen B491

0xygen B491

Palladium

Hydrogen B491 3715

Polymers B522

Review B491 59153

Vycor

Helium 6003

Hydrogen 6003

Neon 6003

Nitrogen 6003

Zirconium

Hydrogen 5726

Sorption, see Adsorption, Degassing

Ce1lulose B491

Space simulator, see Pressure simulator, outer space

Static tube

External interference effects, supersonic speed 5956

Theory, low Reynolds Nos. 58100

Steel

Degassing, see

Diffusion, see

Sticking probability, see Condensation coefficient

Surface area of solids and gases

Barium getter 60506051

Bibliography 51656068

Glass 4823

Measurement 6050605160686082

Low temperature adsorption of a gas (BrunauerEmmett) 441145086093 Adsorption of Krypton used 450760110 Oxide-coated cathodes 4308

Review B491 B514 B601 45085165

Sma11 areas B491 4507

Molecular areas, see Molecules

Ratio true to apparent B491

Review B491 B514 B601 51656068

Silicon 6093

Theory 5165

Surface chemistry of solids B514 B601

Surface reaction phenomena and techniques

Electron emission, strong electric fields, see

Field emission Microscope

Field emission microscope, see

Flash filament techniques

Adsorption measured

Hydrogen and nitrogen on tungsten 5914

Residual gases on metal filaments 6031

Flash filament techniques, ionization gage

Adsorbed nitrogen on tungsten measured 5671

Detecting contaminating gases 5873

Indicator of ultra high vacuum 400748085314 54745874

Work function of tungsten strip observed by photoce11 5236 
Surface reaction phenomena and techniques (cont'd) Oxide cathodes

Thoriated-tungsten filament

Argon, hydrogen and nitrogen ion impact removes thorium 3711

0xygen inactivities 3711

Variations in emitting area 3603

Palladium evaporated films

Various gases 5993

Review B511 B571 59176

Sirrface cleanliness

Crysta1s, determined by electron diffraction 5880

Field emission microscope detects oil molecules 6038

Tungsten, determined by change in emission after flashing 6005

Surface tension

Low temperature melting alloys 5758

Mercury B494

Organic vapors in contact 3301

Review B494

Water

Saturated with organic compounds 3301

Tantalum

Adsorption, see

Degassing, see

Field emission

Oxygen mobility 5259

Filament, hot, adsorbing action

Hydrogen 3208

Nitrogen 3208

Oxygen 3208

Tefion

Water vapor 3208

Degassing data B581 5032525658045869 $0-r$ ings 5814

Gaskets, see

Physical properties B581

Vapor pressure 5666

Terminology

American Vacuum Soc. 58148

British 58104

German B581

Symbo1s, German B581

Vacuum grades 5814858155

Thermal conductivity, see Heat conductivity of gases

Thermal conductivity gages

Bimetal gages, see Pirani gages

Expansion gages, see

Pirani, see Pirani gages

Reviews, see Books and surveys

Thermister, see Pirani gages

Thermocouple, see Thermocouple vacuum gages

Thermionic emission, see Electron emission from

cathodes

Thermistors

Physical properties 4626

Pirani gage, see

Stability 5610

Thermocouples

Welding techniques 4604

Thermocouple vacuum gages

Design 561857825868

A11 meta1 4612

Combined with ionization gage 4809
Thermocouple vacuum gages (cont'd)

Design (cont'd)

Maximum sensitivity 52165217

Resistor in paralle1 with filament 5217

Multiple pressure ranges 52455646

Theva 5270

Mode of heating couple

Electrical 40104012410546065572

Automatic control 5868

Radiation

Electric light 1405

Wire spiral 2605

Mode of indication

Galvanometer 40124605

Milliameter 4606

Millivoltmeter 40104105

Output operates contro1ler 4605

Performance $48095245 \quad 5572 \quad 5618 \quad 5646 \quad 5868$

Calibration not linear 4606

Heating current effect B491

Radiation effects 2605

Review B491 B571

Sensitivity, various gases

Argon 47055216

Carbon dioxide 4705

Carbon monoxide 4705

Ethane 4704

Hydrogen 47045216

Methane 4704

Nitrogen 4704

Oxygen 4704

Water vapor 470452165270

Xenon 47045216

Temperature, ambient, effect of 5270

Pressure range, high, $\mathrm{mm} \mathrm{Hg}$

$.1,4809$

$.2,4612$

1, 460546065782

3,5618

5,5868

10, 401041055646

Pressure range, low, mm Hg

10-1, 4105

$5 \times 10^{-2}, 5618$

$10^{-2}, 5868$

$5 \times 10^{-3}, 4605$

$10-3,46064612480956465782$

$3 \times 10^{-4}, 2605$

$10-4,4010$

$10^{-5}, 40125216$

Review B391 B491 B571 31095144

Theory 480952165217

Thermocouple materials

Chrome1-alume1 B491

Constantan-manganin 4010

Copper-constantan B491 2605

Wa11 temperature contro1 B491

Thermomolecular flow theory B491

Thin films, evaporated

Adsorption, see

Degassing of melted metal $B 572$

Gas content 59162

Interaction with krypton

Theory 5991

Palladium

Surface reaction, various gases 5993

Porosity B583 
Thin films, evaporated (cont'd)

Production B513 59162

Review B572

Vacuum effects B572

Thorium, see Adsorption, Diffusion, Getters

Titanium

Cleanliness of crystal surface 5880

Gettering action, see Getters

Hydrogen adsorption 59169

Vapor pressure 59169

Titanium oxide

Photo desorption 6088

Torque-pressure balances, see also Flowmeters,

Vapor pressure measurement

Pressure measured by reaction of flowing gas 3210

Radiometer application, see Radiometers

Transducers, see also Piezoelectric gages

Inductance 5103

Review B592

Transistors B542

Circuits $\mathrm{B} 602$

Traps, see also Pumps, cryogenic

Alumina pellets

Absorbs oil vapor products 6011

Carbon 58159

Co1d

Coil, 1iquid nitrogen 5541

Conduction type

Copper rod in 1iquid 53365747

Dewar flasks

Design improvements 5232

Performance 5232

Theory, gaseous heat conductivity 5816

Effect on pressure indicated by McLeod gage 3211

Insulation materials, see

Leaks in stainless stee1 5155

Light beam passes through 5334

Liquid air 1402

Liquid nitrogen 586459355936598159141 59158

Leve1 controller 5884592960124

Stainless steel corrugated sheet in liquid 5370

Copper foil

Cooled by liquid nitrogen 59143

Design 5853

Performance 533054635853

Mercury 5820

U1tra-high vacuum 58535864598159143

Mechanical refrigeration system 5544

U1tra-1ow temperature 59166

Review

English 59114

Russian 5927

U1tra-high vacuum 5874

Zeolite, artificial

Design

U1tra high vacuum 5906

Performance 5906

Tubing

Conductance of, see F1ow of gases

Coupling for 5457

Tungsten, see also Gettering action, ionization gages

Adsorption of gases, see

Caesium film 33075554
Tungsten ( cont $\%$ )

Cleanliness of surface

Determined by emission change after flashing 6005

Condensation coefficient, see Sticking coeffi-

cient

Contact potential, barium 3502

Degassing, see

Filaments

Produce hydrogen and carbon monoxide 59136

High temperature reactions in vacuum, see also

Adsorption, activated, Electron emission

Air 5253

Acids 5253

A1kalis 5253

Carbon 5253

Oxide

Nitrogen 5253

Formation 48215253

Reduction 4821

Photoelectric emission 48084811

Rate of evaporation B491

Single crystal

Adsorption

Barium 39095161

Caesium 3809

Hydrogen 5889

Tungsten 5161

Cleaning surface techniques 40075161

Thorium film 3307

Vapor pressure, see

Work function 130435023808

Indicates pressure 380840064811

Units, pressure

Conversion table B581 6009

Gaede (micro Newtons $/ \mathrm{m}^{2}$ ) 5933

Pasca1 (Newton $/ \mathrm{m}^{2}=10$ dynes $/ \mathrm{cm} 2$ ) 5933

Review B491

Units, flow

Clusec 5933

Lusec 5933

Review B491

Universa1 vacuum joint

For rotating apparatus 5449

Upper atmosphere

Pressure measurement, see

Vacuscope (Swivelling McLeod gage), see Mcleod gages

Vacuum controllers, see Pressure contro1lers

Vacuum distillation 4414522352245225

Evaporator 5780

Review B581

Vacuum engineering

Design data, graphical 540455486067

Vacuum gages, see Pressure measurement Calibration, see Calibration methods Reviews, see Books and surveys

Vacuum lock

Mass spectrometer, solid samples 5341

Vacuum measurement, see Pressure measurement

Vacuum measurement, general

Merits of various type gages B491

Pressure range of various gages, see Review 5875

U1tra-high 58745911359114 
SUBJECT INDEX (cont'd)

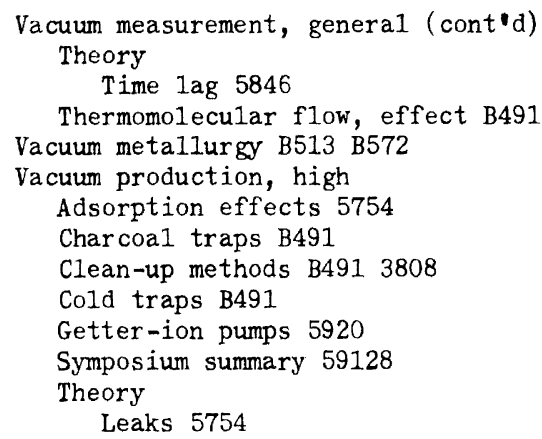

Vacuum systems (cont'd)

Particle accelerator

Getter-ion pumps used 5920

Pressure simulation, outer space 5914259154

Protective devices 5247

Circuits 48104918503958157

Seals, see

Space simulation, see Pressure simulation, above

Transfer of motion into, see Seals

Traps, see

U1timate vacuum techniques, large volumes 58159

U1tra-high vacuum 553356245867587459143

5915759158591635916460156086

Residual gases, see

Valves, see

Vacuum techniques

Bibliography B581 516659106

Clean surfaces 5314

Degassing, see

Differential vacuum maintained 5777

High vacuum 60120

Leak detection, see

Low temperature 58160

Mass spectrometry, see

Pumping, see Getter-ion pumps, Pumps diffusion

Reviews, see Books and surveys

Seals, see

Surface phenomena 48085314

U1tra-high vacuum 516154635514587459155936 597959805949591646038

Valves, see also Seals, Leaks, controlled gas Applications

Accelerator system 5928

Barometer tube 5455

Diffusion pump line 5440

F1ow contro1 560760101 Chlorine 60103

Gas injection 6074

Low temperature 58160

Mercury manipulation 5745

Safety, see below

Stellerators 5856

U1tra-high vacuum $54465524 \quad 5628 \quad 5717 \quad 5979$ 5911659120

Automatic, pressure controlled 5468

Ball check valves, control mercury flow 5745

Bibliography 5320

Indium seal

Float controls leve1 571759116

Mechanica1

A11 metal 5533592760101

Aluminum seal, valve stem compresses 5979

Bakeable 5310585659124

Ba11 and socket, solenoid operated 562859115

Bellows seal Mechanically operated A11 metal 5913 U1tra-high vacuum 5904 Operated by air pressure Seats metal disk on $0-r$ ing 5440

Cone seal 5927

Copper seat

Kovar cone 5120

Metal cone 59124

Mone1 metal nose 5346

Differential expansion, glass and metal plug 5607 
Valves ( cont'd)

Mechanical (cont'd)

Disk, material

Brass, magnetically seated, fast-acting 6074

Copper, large, sealed by high fluid pressure 59165

Indium sea1 5547

Neoprene sea1 5459

Gate valve, large 5346

Electrically triggered 5626

Glass seat, teflon cone 5455

Indium gasket 55305547

High gas conductance 5023

Multiple 5049

Disk, rotating, metal 5364

Piston, position controlled 5461

Needle valve

Diaphragm deflection contro1 60101

Solenoid controlled 5831

Spring controlled 5324

Vibrated, amplitude controls leak 5326

Piston position controlled

Glass, magnetic force 5446

Large diameter, multiple 5452

$0-r i n g$ sea1 51315461

Pressure contro1led 5749

Plug valve 5460

Silver ring, monel nose 5524

Spring closure, solenoid opens 5040

Stopcock

Glass, end cover seal 5538

Mercury sealed 5239

Meta1, 0-ring seal 5460

Teflon disk, bellows controlled 5338

Teflon seat 6074

Mercury leve1, control

Magnetically operated float 51305606

Pressure controlled

Sintered disk mercury seal 504456065642

Performance

Leakage 552459124

Magnetically operated disk valve 6074

Review B492 B551 B581 5320

U1tra-high vacuum 587458120

Safety against sudden pressure changes

Gate type, electrically triggered 5626

Piston, closed by atmospheric pressure 5986

Silver chloride in capillary 60103

Theory, fast-acting magnetic valve 6074

Tin seal

Melted by hf current 5830

Molten, cup lowered into tin for seal 59120

Wood's metal seal 5739

Vapor condensation

Cold surface, ultra-high vacuum

Theory 5842

Vapor pressure

Alcoho1s, low temperature 5946

A1loys B491

Low temperature melting 5758

Ama1gams 59138

Bibliography 4712

Caesium 6058

Calcium 5441

Cements, vacuum 3309

Chlorides 5527

Greases B491
Vapor pressure (cont'd)

Inorganic compounds B491 4712

Low temperature data B491

Mercury 3210

Ama1gams 59138

Meta1s B491 B551 B581 54475527

Monotomic vapors 4104

Organic substances B541 B581 4712

Buty1 phthalate 3906

Tri cresy1 phosphates 3906

Oxides B491 5527

Plastics 5666

Pump oils, see

Review B491

Silicone 5354

Review B491 5527

Sulphides 5527

Theory B491

Titanium 59169

Tungsten 13025448

Waxes B491

Vapor pressure measurement, vacuum range

Caesium, collected on tungsten, measured by

flash technique 60586059

Dead weight disc valve, see Mechanical pressure and vacuum gages

Effusion, two reservoirs connected by tube of known conductance 5268544155235649

Error, usually neglected 5649

Gasometer, Dubrovin 4807

Microbalance, impact on 5788

McLeod gage

Measures pressure restoring diaphragm to null position 5629

Technique for condensible vapors 5643

Molecular beam impact

Streaming vapor twists vane and torsion wire 5946

Pendulum gage, see Gravity disc valve, above

Piston, mica, quartz spring 5518

Pumping against restriction until pressure constant 3309

Radioactive ionization gage 5640

Radiometer gage 5034

Combined with viscosity gage 5560

Review 5643

Vibration-free mountings for instruments 5682

Viscosity

Dependence on mean free path and molecular diameter B491

Low pressures B491

Gases B491

Temperature effect $B 491$

Exponential equations B491

Sutherland's equation B491

Viscosity vacuum gage

Decrement type

Disc, angular oscillations B491

Fiber, oscillating B491

Bifilar 53185819

Design B391 B491 14042504390353195453

Performance B491 5319

Molecular weight effect 5318

Recorder

Capacitance pickup, decay of frequency 5453

Theory 140453185319 


\section{SUBJECT INDEX (cont'd)}
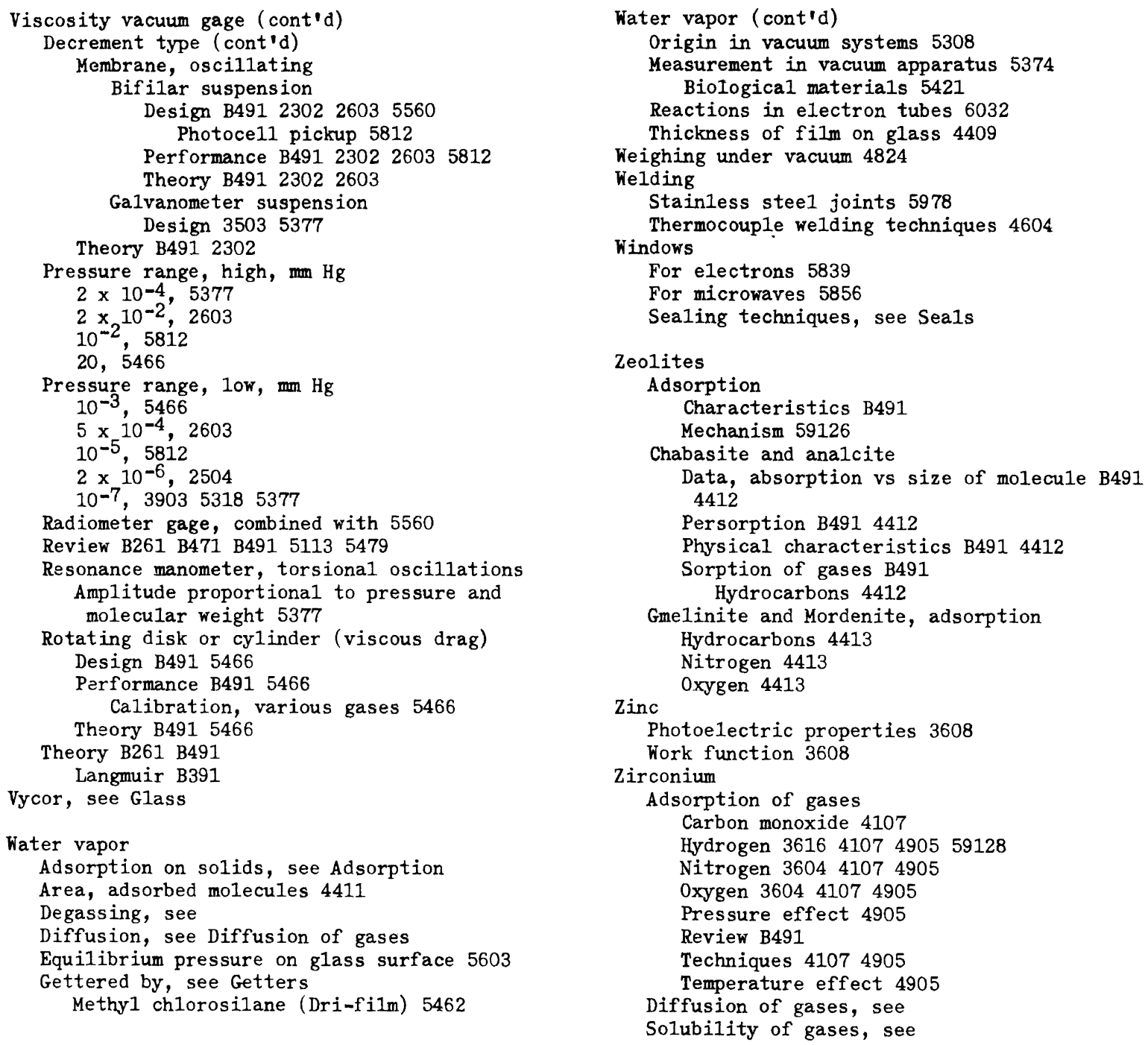


\section{THE NATIONAL BUREAU OF STANDARDS}

The scope of activities of the National Bureau of Standards at its major laboratories in Washington, D.C., and Boulder, Colorado, is suggested in the following listing of the divisions and sections engaged in technical work. In general, each section carries out specialized research, development, and engineering in the field indicated by its title. A brief description of the activities, and of the resultant publications, appears on the inside of the front cover.

\section{WASHINGTON, D.C.}

Electricity. Resistance and Reactance. Electrochemistry. Electrical Instruments. Magnetic Measurements. Dielectries. High Voltage.

Metrolocy. Photometry and Colorimetry. Refractometry. Photographic Research. Length. Engineering Metrology. Mass and Scale. Volumetry and Densimetry.

Heat. Temperature Physics. Heat Measurements. Cryogenic Physics. Equation of State. Statistical Physics.

Radiation Physics. X-Ray. Radioactivity. Radiation Theory. High Energy Radiation. Radiological Equipment. Nucleonic Instrumentation. Neutron Physics.

Analytical and Inorganic Chemistry. Pure Substances. Spectrochemistry. Solution Chemistry. Standard Reference Materials. Applied Analytical Research.

Mechanics. Sound. Pressure and Vacuum. Fluid Mechanics. Engineering Mechaniss. Rheology. Combustion Controls.

Organic and Fibrous Materials. Rubber. Textiles. Paper. Leather. Testing and Specifications. Polymer Structure. Plastics. Dental Research.

Metallurgy. Thermal Metallurgy. Chemical Metallurgy. Mechanical Metallurgy. Corrosion. Metal Physics. Electrolysis and Metal Deposition.

Mineral Products. Engineering Ceramics. Glass. Refractories. Enameled Metals. Crystal Growth. Physical Properties. Constitution and Microstructure.

Building Research. Structural Engineering. Fire Research. Mechanical Systems. Organic Building Materials. Codes and Safety Standards. Heat Transfer. Inorganic Building Materials.

Applied Mathematics. Numerical Analysis. Computation. Statistical Engineering. Mathematical Physics. Operations Research.

Data Processing Systems. Components and Techniques. Digital circuitry. Digital Systems. Analog Systems. Applications Engineering.

Atomic Physics. Spectroscopy. Infrared Spectroscopy. Solid State Physics. Electron Physics. Atomic Physics.

Instrumentation. Engineering Electronics. Electron Devices. Electronic Instrumentation. Mechanical Instruments. Basic Instrumentation.

Physical Chemistry. Thermochemistry. Surface Chemistry. Organic Chemistry. Molecular Spectroscopy. Molecular Kinetics. Mass Spectrometry.

Office of Weights and Measures.

\section{BOUlder, COLO.}

Cryogenic Engineering. Cryogenic Equipment. Cryogenic Processes. Properties of Materials. Cryogenic Technical Services.

Ionosphere Research and Propagation. Low Frequency and Very Low Frequency Research. Ionosphere Research. Prediction Services. Sun-Earth Relationships. Field Engineering. Radio Warning Services.

Radio Propagation Engineering. Data Reduction Instrumentation. Radio Noise. Tropospheric Measurements. Tropospheric Analysis. Propagation-Terrain Effects. Radio-Meteorology. Lower Atmosphere Physics.

Radio Standards. High Frequency Electrical Standards. Radio Broadcast Service. Radio and Microwave Materials. Atomic Frequency and Time Interval Standards. Electronic Calibration Center. MillimeterWave Research. Microwave Circuit Standards.

Radio Systems. High Frequency and Very High Frequency Research. Modulation Research. Antenna Research. Navigation Systems.

Upper Atmosphere and Space Physics. Upper Atmosphere and Plasma Physics. Ionosphere and Exosphere Scatter. Airglow and Aurora. Ionospherio Radio Astronomy. 
